\title{
Funktionelle Charakterisierung der
}

\section{Replikations- und Rekombinationsfunktionen \\ der RNA-abhängigen RNA-Polymerase (RdRp) \\ des Potato virus $X$ (PVX)}

\author{
Dissertation \\ zur Erlangung des Doktorgrades \\ der Fakultät für Agrarwissenschaften \\ der Georg-August-Universität Göttingen
}

vorgelegt von

Diplom Biologin

Heidrun-Katharina Draghici

geboren in Sibiu/Hermannstadt (Rumänien)

Göttingen, im Dezember 2008 
D 7

1. Referent: Prof. Dr. Mark Varrelmann

2. Korreferent: Prof. Dr. Edgar Maiß

Tag der mündlichen Prüfung: 22.01.2009 
„In der Natur ist die Bedeutung des unendlich Kleinen unendlich groß.“

[Louis Pasteur] 
Für meine Familie 


\title{
INHALTSVERZEICHNIS
}

\author{
Abkürzungsverzeichnis
}

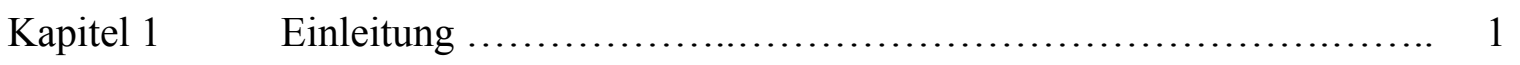

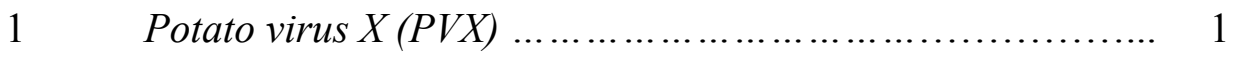

1.1 Wirtspflanzenspektrum und Krankheiten .................. 1

1.2 Relevanz und Bekämpfung ............................... 1

1.3 Übertragung und Ausbreitung des PVX .................. 2

$1.4 \quad$ Genomorganisation des PVX ............................ 2

1.5 Genfunktionen einschließlich nicht codierender Bereiche des PVX .......................................... 3

2 Replikation von (+)-Strang RNA-Viren ................... 5

2.1 Replikations/RdRp-Komplexe und replikative intermediäre Formen (RIF) ...................................... 6

2.2 Klassifizierung der Replikasen der (+)-Strang RNA-Viren ... 6

2.3 An der Replikation beteiligte RNA Elemente von Potexviren ......................................... 9

2.3.1 „Cis-acting“ RNA-Elemente in der 5'-NTR .................. 9

2.3.2 „Cis-acting“ RNA-Elemente in der 3'-NTR .................. 10

$2.4 \quad$ Replikation des Potato virus X(PVX) ...................... 11

2.5 Wirtsproteine und Replikation der ,alpha-like“ Pflanzenviren ......................................... 11

3 Variation und Evolution von Pflanzenviren ................. 13

3.1 Mechanismen der Virusevolution ............................ 13

3.2 Mutation: Mutationsrate und -frequenz ................. 13

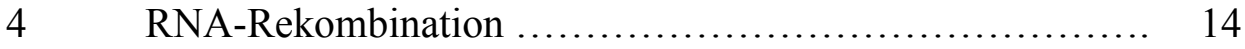

4.1 Quasi-Spezies .................................... 15

4.2 Natürliche Rekombination innerhalb der Viren und subviraler Spezies .................................... 16

4.3 Vorkommen der RNA-Rekombination innerhalb verschiedener Organismen ............................... 17

4.4 Klassifizierungen der RNA-Rekombination ................. 18 
4.4.1 Klassifizierung der RNA-Rekombination nach Lai (1992) ... 18

4.4.2 Klassifizierung der RNA-Rekombination nach Nagy und Simon $(1997)$........................................... 19

4.5 Putative Mechanismen der RNA-Rekombination ............ 21

4.6 Pseudorekombination (,Reassortment" $\left.{ }^{6}\right) \ldots \ldots \ldots \ldots \ldots \ldots . \ldots 25$

5 Zielstellung dieser Arbeit ............................ 25

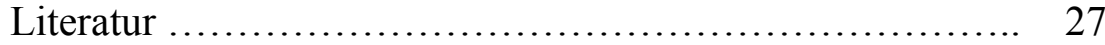

Kapitel 2 Functional mapping of PVX RNA-dependent RNA-replicase using pentapeptide scanning mutagenesis - Identification of regions essential for replication and subgenomic RNA amplification ........ 49

- Abstract ................................................. 49

- Introduction .............................................. 50

- Materials and Methods ..................................... 54

- Results ................................................ 57

- Discussion ................................................ 67

- Acknowledgments ...................................... 70

- References .............................................. 70

Kapitel 3 Evidence that the linker between methyltransferase and helicase domains of the potato virus $\mathrm{X}$ replicase is involved in homologous RNA recombination ......................................... 79

- Abstract ................................................ 79

- Introduction ............................................. 80

- Materials and Methods ...................................... 82

- Results ............................................... 86

- Discussion ........................................... 93

- Acknowledgments ........................................ 96

- References ............................................ 96 
Kapitel 4 Potato virus X RNA recombination is determined by structural parameters and occurs frequently at preferentially predicted stem-

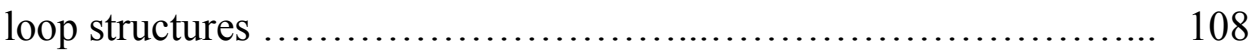

- Materials and Methods.................................... 108

- Results ................................................ 111

- References ............................................ 124

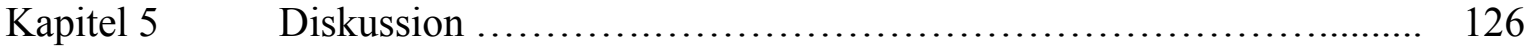

- Literatur ................................................ 139

Zusammenfassung ......................................................... 147

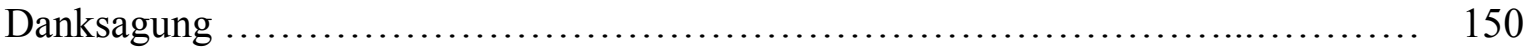

Lebenslauf ............................................................... 151 

Abkürzungsverzeichnis
As
- Aminosäure
Acc.
- „accession”
AHR
- aberrante homologe Rekobination
A. tumefaciens
- Agrobacterium tumefaciens
Abb.
- Abbildung
BaMV
- Bamboo mosaic virus
BMV
- Brome mosaic virus
bp
- Basenpaar(e)
bzw.
- beziehungsweise
ca.
- circa
CaMV
- Cauliflower mosaic virus (Blumenkohlmosaikvirus)
cDNA
— „complementary“ (komplementäre) DNA
$\mathrm{cm}$
- Zentimeter
$\mathrm{CP}$
- „coat protein” (Hüllproteingen)
dATP
- Desoxyadenosintriphosphat
de novo
- von Neuem, von Anfang an
DNA
— „desoxyribonucleic acid“ (Desoxyribonukleinsäure)
DNase
- Desoxyribonuklease
dNTP
- Desoxyribonukleotid-5'-triphosphat
d.h.
- das heißt
dpi
- „day(s) post inoculation“ (Tage nach Inokulation)
DSMZ
- Deutsche Sammlung von Mikroorganismen und Zellkulturen, Braunschweig
dsRNA
- doppelsträngige RNA
E. coli
- Escherichia coli
et al.
- et alii, und andere
$\mathrm{EtOH}$
- Ethanol
Fig.
- Figure (Abbildung)
FM
- „epifluorescence microscopy”
gRNA
- genomische RNA
GFP
- „green fluorescent protein“
HEL
- Helikase 


\begin{tabular}{|c|c|}
\hline HR & - homologe Rekombination \\
\hline $\operatorname{IgG}$ & - Immunoglobulin $\mathrm{G}$ \\
\hline $\mathrm{kb}$ & - Kilobase (n), = 1000 Basenpaare \\
\hline $\mathrm{kDa}$ & - Kilodalton \\
\hline M & - Molar \\
\hline $\mathrm{mg}$ & - Milligramm \\
\hline $\mathrm{Mg}$ & - Magnesium \\
\hline MGS & - „mutation generation system“ \\
\hline $\min$ & - Minuten \\
\hline $\mathrm{ml}$ & - Milliliter \\
\hline mRNA & — „messenger“ Ribonukleinsäure \\
\hline MT & - Methyltransferase \\
\hline MW & - Molekulargewicht \\
\hline N. benthamina & - Nicotiana benthamiana \\
\hline NHR & - nicht homologe Rekombination \\
\hline $\mathrm{nm}$ & - Nanometer $\left(10^{-9} \mathrm{~m}\right)$ \\
\hline no. & - „number“ (Nummer) \\
\hline $\mathrm{nt}$ & - Nukleotid \\
\hline NTP & - Nukleosidtriphosphat \\
\hline NTR & - nicht-translatierte Region bzw. Bereich \\
\hline \multirow[t]{2}{*}{ OD } & - „optical density“ \\
\hline & (optische Dichte bei angegebener Wellenlänge) \\
\hline Oligo-dT & - Oligodeoxythymidin \\
\hline ORF & — „open reading frame“ (offener Leserahmen) \\
\hline \multirow[t]{2}{*}{ PCR } & - „polymerase chain reaction” \\
\hline & (Polymerase-Kettenreaktion) \\
\hline POL & - Polymerase \\
\hline PPV & - Plum pox virus \\
\hline PS & - „pentapeptide scanning” \\
\hline PSM & - „pentapeptide scanning mutagenesis“ \\
\hline PVX & - Potato virus $X$ \\
\hline PVY & - Potato virus $Y$ \\
\hline $\operatorname{RdRp}$ & - „RNA-dependent RNA-polymerase” \\
\hline $\mathrm{RF}$ & - replikative Form \\
\hline
\end{tabular}




\begin{tabular}{|c|c|}
\hline RFLP & - Restriktions-Fragment-Längen-Polymorphismus \\
\hline RIF & - replikative intermediäre Form \\
\hline RNA & — „ribonucleic acid“ (Ribonukleinsäure) \\
\hline \multirow[t]{2}{*}{ SDS-Page } & - Natriumdodecylsulfat (,,sodium dodecyl sulfate“) \\
\hline & - Polyacrylamid-Gelelektrophorese \\
\hline SER & - „Similarity-Essential” Rekombination \\
\hline $\operatorname{sg}$ & - subgenomisch \\
\hline $\operatorname{sgPr}$ & - subgenomischer Promotor \\
\hline sgRNA & - subgenomische RNA \\
\hline SL & - „stem-loop“ \\
\hline SNER & — „Similarity-Nonessential” Rekombination \\
\hline s.o. & - siehe oben \\
\hline ss-RNA & - „single-stranded” RNA \\
\hline Taq-Polymerase & - Termus aquaticus DNA-Polymerase \\
\hline TGB & — „triple gene block” \\
\hline $\mathrm{TL}$ & - „tetraloop” \\
\hline T-DNA & - Transfer-DNA \\
\hline u.a. & - unter anderem \\
\hline usw. & - und so weiter \\
\hline UV & - Ultraviolettes Licht \\
\hline $\mathrm{V}$ & - Volt \\
\hline $\mathrm{v} / \mathrm{v}$ & - „volume per volume” (Volumen pro Volumen) \\
\hline Vol & - Volumen \\
\hline WT & — „wildtyp” \\
\hline $\mathrm{w} / \mathrm{v}$ & — „weight per volume” \\
\hline z.B. & - zum Beispiel \\
\hline z.T. & - zum Teil \\
\hline
\end{tabular}


$\mu \mathrm{g}$

$\mu l$
- Alpha

- Beta

- Grad Celsius

- Lambda

- dreidimensional

- Microgramm

- Microliter 


\section{Kapitel 1}

\section{Einleitung}

\section{Potato virus $X(\mathrm{PVX})$}

\subsection{Wirtspflanzenspektrum und Krankheiten}

Das Potato virus X (PVX), vom Typstamm des Genus Potexvirus, gehört zu der Familie der Flexiviridae (Adams et al., 2004). Erstmals wurde PVX in Kartoffeln (Solanum tuberosum) von Smith (1931) beschrieben. Zum natürlichen Wirtskreis des PVX gehören außer der Kartoffel, an der überwiegend Schäden verursacht werden, andere Nachtschattengewächse (Solanaceae), wie z.B. Tomaten (Lycospersicon esculentum) und Tabak (Nicotiana tabacum). Experimentell eignen sich für die Erhaltung des Virus N. tabacum und N. benthamiana. Das PVX verursacht an Kartoffeln eine Scheckung der Blätter, die wie ein Mosaik aussieht. Das Virus kann allerdings bei Kartoffeln in Abhängigkeit vom Genotyp und Umweltbedingungen auch latente symptomlose Infektionen hervorrufen. In Tabak können auch noch zusätzlich nekrotische Ringflecken an den Blättern als Symptom vom Virus hervorgerufen werden. An Tomaten sind Wachstumshemmungen, d.h., Stauchungen der Pflanze sowie nekrotische Lokalläsionen und Mosaiksymptome auf den Blättern zu erkennen (Smith et al., 1988).

\subsection{Relevanz und Bekämpfung}

Um die Infektionen durch PVX weltweit effektiv kontrollieren zu können, ist es der Züchtung gelungen, verschiedene resistente Kartoffelsorten, die mit Hilfe von so genannten dominanten Resistenzgenen ( $\left.N x, N b, R x_{a d g}, R x_{a c l}\right)$ erzeugt wurden, herzustellen. Moreira et al., 1980 zeigte jedoch, dass diese unterschiedlichen Resistenzen bis dato von einem südamerikanischen Isolat $\left(\mathrm{PVX}^{\mathrm{HB}}\right)$ gebrochen werden konnten. Einen detaillierten Übersichtsartikel über die Resistenzzüchtung bei Kartoffeln unter Berücksichtigung der pathogenvermittelten Resistenz gegenüber Potato virus $X$ publizierten Solomon-Blackburn \& Barker (2001a und b). Generell spielt PVX jedoch eine untergeordnete Rolle gegenüber den nicht persistent blattlausübertragbaren Viren wie PVY (95 \%) in Deutschland (persönliche Mitteilung, Volker Zahn, Pflanzenschutzamt Hannover). 


\section{3 Übertragung und Ausbreitung des PVX}

Durch den Kontakt von Pflanzenteilen erfolgt fast ausschließlich die Übertragung des Potato virus $X$, d.h., es wird hauptsächlich mechanisch übertragen (durch den Gebrauch von landwirtschaftlichen Geräten, z.B. bei der Unkrautbekämpfung oder der Pflanzung). In der Literatur werden folgende Vektoren für die Virusübertragung beschrieben: der Bodenpilz Synchytrium endobioticum (Nienhaus \& Stille, 1965; Campbell, 1979) und die Grashüpfer Melanoplus differentialis (Walters, 1952) und Tettigonia viridissima (Schmutterer, 1960). Die PVX-infektionsbedingten Ertragseinbußen liegen weltweit in den Kartoffelanbaugebieten bei 10 - 20 \% (Bode \& Klinkowski, 1968; Koenig \& Lesemann, 1989). Es kann jedoch innerhalb von Mischinfektionen (z.B. mit Potato virus $A, M, Y$ ) zu einer weitaus stärkeren Ausprägung der Symptome kommen, wobei dann letztendlich die Ertragsausfälle um einiges höher sind (Hoffmann \& Schmutterer, 1999).

\subsection{Genomorganisation des PVX}

Wie bereits erwähnt, gehört das Potato virus $X$ (PVX) vom Typstamm des Genus der Potexviren zu der Familie der Flexiviridae (Adams et al., 2004). Die Virionen des PVX sind flexible fadenförmige ca. $515 \mathrm{~nm}$ lange Partikel mit einem Durchmesser von ca. 13 nm (Brandes, 1964).

Die komplette Sequenz des monopartiten (+)-Strang RNA-Genoms mit einer Länge von ca. 6453 Nukleotiden (nt) ist für verschiedene Isolate des PVX bekannt (Bercks, 1970; Huisman et al., 1988; Skryabin et al., 1988; Orman et al., 1990). An beiden Enden der RNA befinden sich nicht-translatierte Bereiche (NTR), die am 5'-NTR 84 nt und am 3'-NTR 72 nt umfassen. Die 5'-NTR Sequenzen variieren ein wenig, wobei die des 3'-NTRs in allen PVX-Isolaten identisch sind (Batten et al., 2003). Neben den NTRs befindet sich am 5'-Ende ein „,m7 GpppG-cap“ (Sonenberg et al., 1978; Huang et al., 2004) und am 3'-Ende ein charakteristischer ,polyA-tail“" (Polyadenylisierungsschwanz) (Morozov et al., 1981; Huisman et al., 1988).

Die genomische RNA des PVX umfasst fünf offene Leseraster (ORFs), die für virale Proteine mit unterschiedlichen Funktionen kodieren (Abb. 1) (Batten et al., 2003; Verchot-Lubicz et al., 2007). 


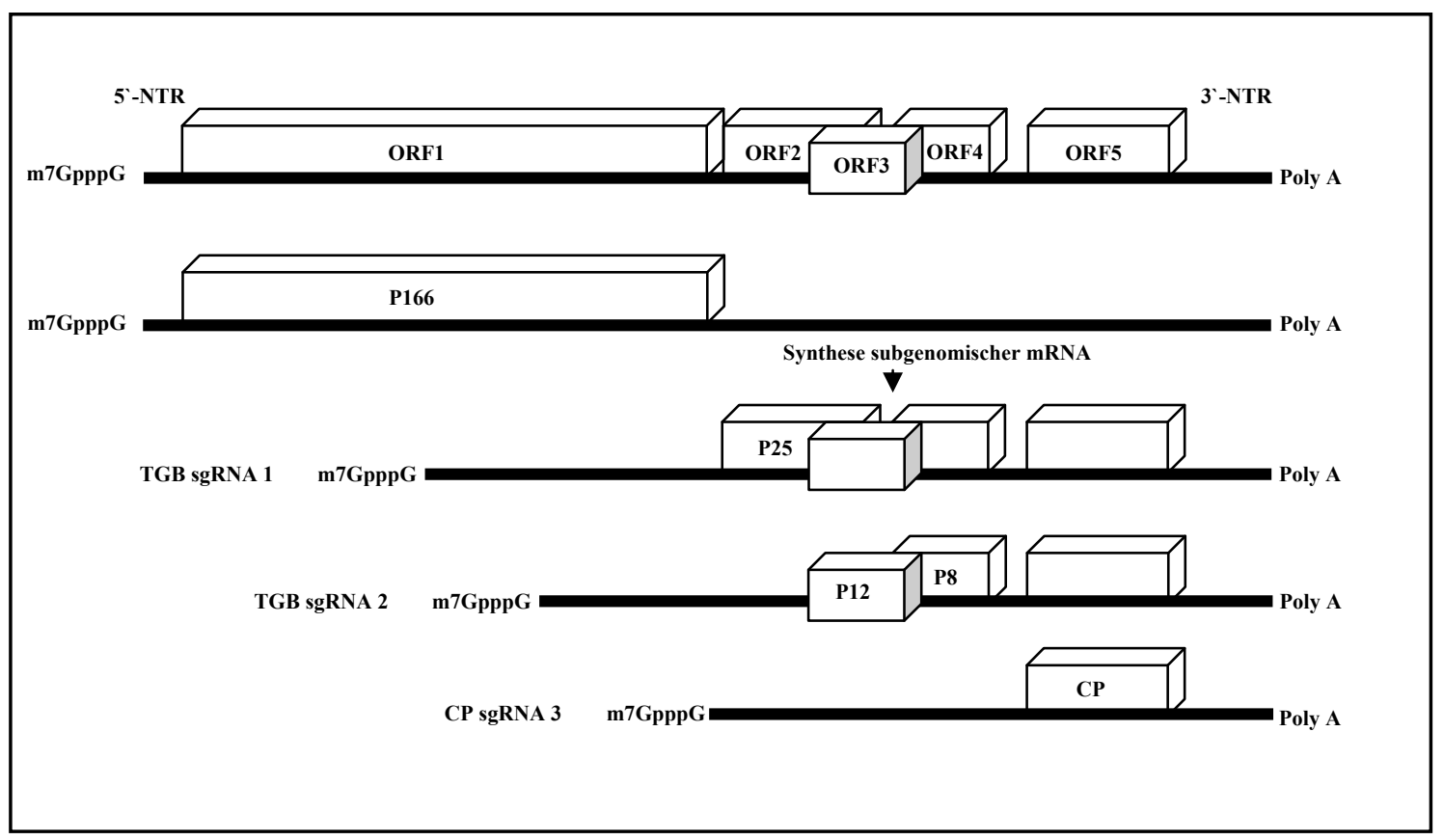

Abb. 1: Schematische Darstellung der Genomorganisation und -expression des Potato virus X (PVX). Die 5 offenen Leserahmen (ORFs) der einzelnen Gene sind in Kästen dargestellt. Die Zahlen geben die ungefähren Molekulargewichte der kodierten Proteine wieder. Die drei subgenomischen RNAs (sgRNA) sind unter dem PVX-Genom aufgeführt. P166 = RdRp (RNA-abhängige RNA-Polymerase oder Replikase); P25, P12 und P8 $=$,triple gene block“ (TGB1-3) ; CP = Hüllprotein

\subsection{Genfunktionen einschließlich nicht codierender Bereiche des PVX}

Der ORF 1 wird direkt von der genomischen ca. 6.4 kb großen RNA translatiert (Abb. 1) und codiert für ein aus 1456 Aminosäuren bestehendes virales Protein, der Replikase bzw. RNA-abhängigen RNA-Polymerase (RdRp), mit einem Molekulargewicht von 166 kDA, welches an der Replikation der viralen RNA beteiligt ist. Auf die genaue Funktion der Replikase wird später noch eingegangen, da dieses Protein in der vorliegenden Arbeit Gegenstand ausführlicher Untersuchungen war.

Die sich zum Teil überlappenden ORFs 2, 3 und 4 sind in einem so genannten ,triple gene block“ (TGB) organisiert. Dieser ist nicht nur für den Genus Potexvirus charakteristisch, sondern auch in vergleichbarer Variante innerhalb verschiedener anderer Genera, wie dem Benyvirus, dem Carlavirus, dem Furovirus, dem Hordeivirus und dem Pecluvirus (Petty \& Jackson, 1990; Beck et al., 1991; Gilmer et al., 1992; Herzog et al., 1998; Morozov et al., 1999). Die Proteine des PVX-TGB werden häufig nach ihrer Abfolge als TGB1 bis 3 bezeichnet, welche eine molekulare Masse von $25 \mathrm{kDa}$ bzw. $12 \mathrm{kDa}$ und $8 \mathrm{kDa}$ besitzen, woraus sich nach Huisman et al., 1988 die Bezeichnung P25 für TGB1, P12 für TGB2 und 
P8 für TGB3 ableitet. Diese Genprodukte des TGB des PVX werden auch Transportproteine genannt, da sie für den Zell-zu-Zell-Transport, d.h. für die Ausbreitung des Virus in der infizierten Pflanze verantwortlich sind (Verchot-Lubicz, 2005). An zwei verschiedenen subgenomischen RNAs (sgRNAs; Abb. 1) erfolgt die Expression dieser Proteine (Morozov et al., 1991; Verchot et al., 1998, Batten et al., 2003). TGB1 ist ein multifunktionelles Protein, welches RNA-Helikase Aktivität aufweist, die Translation der viralen RNA begünstigt und unter anderem RNA-silencing unterdrückt (zusammengefasst in Verchot-Lubicz et al., 2007). Die Sequenz des TGB1 weist außerdem unterschiedliche konservierte Motive auf, die für Proteine mit NTP- und RNA-Bindungsaktivität/ Helikasefunktion charakteristisch sind (Gorbalenya \& Koonin, 1989 \& 1993; Kalinia et al., 2002).

Das Hüllproteingen (CP), das Translationsprodukt des ORF 5, setzt sich aus 238 Aminosäuren zusammen und weist ein Molekulargewicht von ca. 29 kDA auf. Es ist nicht nur für die Enkapsidierung der viralen RNA verantwortlich, sondern spielt ebenfalls eine entscheidende Rolle bei der Ausbreitung des Virus innerhalb der Wirtspflanze (Chapman et al., 1992; Oparka et al., 1996; Santa Cruz et al., 1998). Das Hüllproteingen wird wie obige TGB-Proteine über eine sgRNA exprimiert (zusammengefasst in Batten et al., 2003). Während des Lebenszyklus von Potexviren bindet das Hüllproteingen an die gRNA, um die Virusassemblierung zu initiieren (zusammengefasst in Batten et al., 2003; VerchotLubicz et al., 2007).

Die Sequenz und RNA-Sekundärstruktur des 5'-NTR von Potexviren ist ebenfalls wichtig für Replikation und Assemblierung. Kwon et al. (2005) und Kwon \& Kim (2006) konnten zeigen, dass die „stem-loop“ (SL) 1 Formation und die Sequenz im PVX 5'-NTR notwendig waren für die CP-Bindung, Virusassemblierung und Replikationsinitiierung. Sit et al. (1994) zeigte ebenfalls, dass AC-reiche „,cis-acting“ Elemente im 5'-NTR für die Virusassemblierung wichtig sind, und dass nur 54 nt des 5'-NTR von Papaya mosaic virus (PMV) für die CP-Bindung erforderlich sind. Ähnliche AC-reiche Sequenzen wurden in PVX gefunden (Miller et al., 1998). Generell weist das 5'-Ende der PVX-RNA Signale auf, die an der Translation, Enkapsidierung und genomischer bzw. subgenomischer RNA Synthese beteiligt sind (zusammengefasst in Miller et al., 1998, Verchot-Lubicz et al., 2007). Im 5'-NTR des PVX konnten zwei Regionen, bezeichnet als $\alpha$ (1-41 nt) und $\beta$ (4284 nt) ,cis-acting“ Elemente nachgewiesen werden, die für die Translationseffizienz der Reportergene in vitro verantwortlich sind (Smirnyagina et al., 1991). 
Im Anschluss an den ORF 5 befindet sich der 72 nt große 3'-NTR des (+)-Stranges, der den Promotor für die RdRp (Replikase) zur komplementären (-)-Strang Synthese darstellt. Die Synthese der (+)-Strang RNA wird durch eine Polymerasebindungsstelle am 3'-Ende der (-)-Strang RNA gewährleistet. Folglich weisen ORF 2-4 und ORF 5 interne Promotoren als Startpunkt zur Synthese subgenomischer RNAs auf. Im Allgemeinen ist die subgenomische mRNA-Synthese für alle ORFs, die dem ersten ORF stromabwärts folgen, die am häufigsten verwendete Variante bei den (+)-Strang Viren. In den meisten Fällen ist bei einer solchen mRNA-Synthese eine vorangegangene Promotorregion an der Regulierung der Transkription beteiligt. Zum einen kann sie de novo, beginnend mit einem kompletten (-)-Strang, und zum anderen über einen vorzeitigen Abbruch der Synthese während der (+)-Strang-Synthese mit anschließender Replikation der verkürzten (-)-Strang RNA erfolgen (zusammengefasst in Batten et al., 2003).

\section{Replikation von (+)-Strang RNA-Viren}

Die virale Replikation ist notwendig für die Neusynthese und Vervielfältigung der genomischen RNA, die anschließend für die Bildung neuer infektiöser Viruspartikel benötigt wird. Die Replikation des (+)-Stranges beginnt am 3'-Ende in einem hoch konservierten RNA Bereich (z.B. „cis-acting“ RNA-Elemente). Für (+)-Strang RNA-Viren gilt, sobald das virale Genom das Cytoplasma der Wirtzelle erreicht hat, wird die (+)-sense RNA durch einen internen zellulären Translationsmechanismus für die Translation der Replikase erkannt, welche wiederum notwendig ist für die RNA-Replikation. Bei dem ersten Schritt der Replikation ist die RdRp involviert, die zunächst eine komplementäre (-)-Strang Kopie der genomischen RNA synthetisiert. Anschließend dient diese negativsträngige RNA genomischer Länge als Matrize/Template für die Synthese positivsträngiger genomischer RNA (gRNA). Für die (+)-Strang RNA-Viren, die die Strategie der subgenomische RNA (sgRNA) Expression verwenden, werden einige (+)-Strang sgRNAs von dem (-)-Strang RNA Template gebildet (virale Transkription). Die virale Replikation benötigt außer „cis-acting“ RNA-Elementen, virale- sowie WirtsProteine. Zusammen mit zellulären Proteinfaktoren ist die RNA-abhängige RNAPolymerase (RdRp) oder auch Replikase genannt unabkömmlich in dem Prozess der Replikation. Außerdem spielen RNA-RNA und Protein-Protein Interaktionen eine entscheidende Rolle innerhalb des Replikase/RdRp-Komplexes (zusammengefasst in Hemenway \& Lommel, 2000; Ahlquist et. al., 2002 und 2003). 


\subsection{Replikations/RdRp-Komplexe und replikative intermediäre Formen (RIF)}

Bisher konnte bei jedem eukaryotischen, charakteristischen (+)-Strang RNA-Virus die Beteiligung eines Replikase/RdRp-Komplexes während der viralen Replikation, zusammengesetzt aus Wirtsproteinen an interzellulären Membranen, nachgewiesen werden. Die Membran liefert hierbei eine beständige Oberfläche für die Lokalisierung der Template-RNA, viralen RNA und der Wirtsproteine. Der Replikationskomplex wird am 3 -Ende virusspezifisch gebildet (Teycheney et al., 2000). Die meisten „alpha-like“ Viren (siehe Kapitel 2.2) Replikase/RdRp-Komplexe assoziieren mit endosomalen und lysosomalen Membranen (Kääriäinen \& Ahola, 2002). Aus infizierten Wirten kann zumeist eine dsRNA (doppelsträngige RNA) isoliert werden, die dann als replikative Form (RF) bezeichnet wird. Weiterhin können so genannte replikative intermediäre Formen (RIF) auftreten, hierbei ist dann eine Vielzahl an wachsenden (+)-Strängen mit einer Negativmatrize/(-)-Strang Template verbunden. Für die Initiierung und den Ablauf der (-)-Strang RNA-Synthese sind die 3`-nichttranslatierten Enden/Bereiche primär verantwortlich (Dreher, 1999; zusammengefasst in Hull, 2002).

\subsection{Klassifizierung der Replikasen der (+)-Strang RNA-Viren}

Viren mit (+)-Strang RNA können anhand von Sequenzvergleichen von bisher untersuchten Replikaseproteinen in so genannte „supergroups“ klassifiziert werden. Die Mitglieder einer solchen „supergroup“ weisen gemeinsame Eigenschaften auf, z.B. in ihrer Zusammensetzung des Replikaseproteins (RdRp), der Genomorganisation und ihrer Replikationsstrategien (zusammengefasst in Koonin \& Dolja, 1993). Basierend auf solchen Aminosäure(aa)-Sequenzähnlichkeiten und konservierten funktionellen Domänen der viralen Replikase können (+)-Strang RNA-Viren in 3 Virussupergruppen (,supergroups“) klassifiziert werden, „picorna-like viruses“ (Supergruppe I), „flavi-like viruses“ (Supergruppe II), und ,alpha-like viruses“ (Supergruppe III) (zusammengefasst in van der Heijden \& Bol, 2002). Die meisten ,picorna-like“ Virusgenome (z.B. Nodaviren) werden in ein oder zwei Polyproteinen translatiert bzw. exprimiert, die anschließend durch bestimmte Proteasen gespalten werden. Die „flavi-like“ Viren besitzen eine Helikase (HEL), Methyltransferase (MT) und Serin-spezifische Protease-Domäne in ihrem Replikaseprotein. Im Vergleich dazu besitzen die „alpha-like“ (Supergruppe III) Viren anhand von in silico Sequenzuntersuchungen bekannter Replikaseproteine drei funktionelle Domänen innerhalb ihrer Replikase: Guanylyl-/Methyltransferase-like (MT), Helikase-like 
(HEL) und Polymerase-like (POL) (Koonin and Dolja, 1993, van der Heijden \& Bol, 2002) und eine Cys-spezifische Protease, bis auf PLP (,papain-like“ Proteinase) bei Togaviren (Abb. 2). Aufgrund von Sequenzhomologien erfolgte eine Klassifizierung dieser Supergruppe III Domänen mit folgender Zugehörigkeit: die MT Domäne gehört zusätzlich zu der Gruppe 1, die HEL Domäne zur Linie 1 und letztlich die POL Domäne zu der Gruppe III (zusammengefasst in van der Heijden \& Bol, 2002).

Mitglieder der Supergruppe III sind Insekten-, Tier- und eine Anzahl von Pflanzenvirengruppen (Abb. 2). Im Wesentlichen wurden innerhalb dieser Supergruppe III Brome mosaic virus (BMV) und Tobacco mosaic virus (TMV) Pflanzenviren untersucht. Auf letztere wird in dieser Arbeit im Detail eingegangen, da Potato virus X (PVX) der „alpha-like“"Virusgruppe zugehörig ist.

\section{Pflanzenviren:}
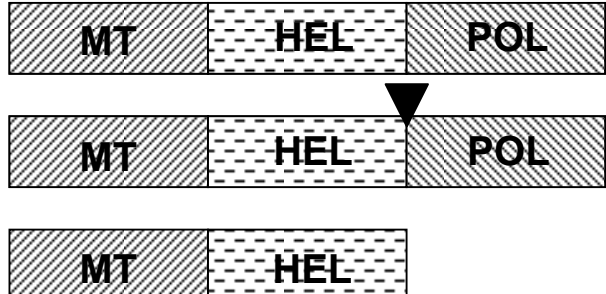

$$
\mathrm{HEE}
$$$$
\text { PRO }
$$

PRO

HE:

\section{PRO}

Potex-, Idaeo-, Allexi- und Foveaviren

Tobamo-, Tobra-, Furo-, Pomo- und Pecluviren

RoL

Bromo-, Cucumo-, Alfamo-, llar-, Olea- und Hordeiviren

Tymo- und Carlaviren

Benyviren

Abb. 2: Schematische Darstellung der Organisation von funktionellen Replikase-Elementen bzw. Domänen der Pflanzen ,alpha-like“ Virusgruppe (modifiziert nach van der Heijden und Bol, 2002). Methyltransferase (MT), Helikase (HEL) und Polymerase (POL) -Domänen, die in allen Mitgliedern einer Virenfamilie vorkommen. Einige Viren codieren die POL-Domäne via „readthrough“, d.h. Überlesen ein Stopcodon ( $\nabla)$. PRO kennzeichnet Proteinasen, anhand derer einige Polyproteine gespalten werden.

In Potexviren werden diese drei konservierten funktionellen Domänen immer in derselben Orientierung MT-HEL-POL (beginnend vom N- zum C-Terminus) in einem „single protein" exprimiert (zusammengefasst in Kääriäinen \& Ahola 2002). Die N-terminale Guanylyl-/ Methyltransferase Domäne ist hierbei für das 5'-capping der genomischen und subgenomischen RNA verantwortlich (Rozanov et al., 1992) und wird in zwei Gruppen 
unterteilt (Koonin, 1993). Li et al. (2001a und b) konnte zusätzlich in Bamboo mosaic virus (BaMV) zeigen, dass diese MT Domäne eine RNA 5'-triphosphatase Aktivität besitzt. Hingegen werden die zentral gelegene putative Helikase sowie die C-terminale Polymerase jeweils noch in drei zusätzliche Linien bzw. Familien gruppiert (Gorbalenya et al., 1989 und 1990; Koonin, 1991; Gorbalenya \& Koonin, 1993; Koonin \& Dolja, 1993). Die Helikase ist im Allgemeinen an dem Prozess der RNA-Replikation sowie an der Entwindung der RNA-Duplexstruktur beteiligt, d.h., mit Hilfe des Energiegewinns aus der Hydrolyse des NTPs (Nukleosid-5'-triphosphates) kann die RNA-Helikase die doppelsträngigen RNA-Stränge in ihre Einzelstränge entwinden. Weiterhin stellten Li et al. (2001b) die Vermutung auf, dass die HEL Domäne von BaMV eine doppelte Funktion übernimmt, zum einen die erwähnte Beteiligung an dem Prozess der RNA-Replikation und zum anderen an der Formation der 5'-capping Struktur der RNA. Die konservierten Sequenzmotive der Helikase (+)-Strang RNA-Viren wurden aufgrund zahlreicher Sequenzhomologien und Anordnung dieser HEL Motive in drei zusätzliche Superfamilien (SF1-SF3) sowie zwei kleinere F4 und F5 Familien kategorisiert (Ilyina et al., 1992; Gorbalenya \& Koonin, 1993; Kadare \& Haenni, 1997; Hall \& Matson, 1999). Die Mehrheit der (+)-Strang RNA-Viren sind Mitglieder der SF1 Familie wie, z.B. das Potato virus X. Für Hordeiviren und PVX konnte bereits eine Helikaseaktivität des TGB1Proteins, d.h., eine bewiesene Na-Duplex-Entwindungsaktivität mit 5'-3'-Polarität nachgewiesen werden (Seybert et al., 2000a und 2000b; Kalinina et al., 2002; Leshchiner et al., 2006). Die sich im C-Terminus befindende Polymerase wird auch als katalytische Domäne bezeichnet und ist verantwortlich bzw. notwendig für die virale Genomreplikation und RNA-Synthese (Buck, 1996; Lai, 1998; Kao et al., 2001; Ahlquist, 2002).

Die Expression dieser Domänen erfolgt auf unterschiedliche Weise. Einige Viren können wie bereits erwähnt, die MT, HEL und POL Domänen als ein Singleprotein exprimieren (Genus Potexvirus; Huisman et al., 1988; Longstaff et al., 1993), wobei andere drei weitere Strategien verfolgen und dadurch die virale Replikase (RdRp) ausbilden: 1. durch proteolitische Modifikation (z.B. Genus Tymovirus), 2. Expression von 2 unterschiedlichen ORFs (z.B. Genus Bromovirus) und 3. „frame-shifting“ oder ribosomaler „readthrough“ (z.B. Genera Tobamo-, Tobra- und Tombusvirus, siehe Abb. 2) (Buck, 1996; Drugeon et al., 1999; Morozov \& Solovyev, 1999). 


\subsection{An der Replikation beteiligte RNA Elemente von Potexviren}

\subsection{1 „Cis-acting“' RNA-Elemente in der 5'-NTR}

Die 5'-NTR von (+)-Strang RNA-Viren ist charakteristisch für eine bestimmte Zusammensetzung von Sequenzen und Strukturelementen, die mehrere Funktionen, d.h. in der Translation, Enkapsidierung und Replikation, übernehmen. Während der Replikation regulieren die 5'-NTR-Elemente die (+)-Strang RNA und sgRNA Synthese (zusammengefasst in Buck, 1996). Virale Replikasen (RdRps) können vom (+)-Strang RNA-Template zu dem neu zu synthetisierenden (-)-Strang RNA-Template wechseln. In vielen (+)-Strang RNA-Viren konnte der ,core“ promotor für die (+)-Strang RNASynthese in dem 5'-NTR nachgewiesen werden.

Die „,cis-acting“ RNA-Elemente in der 5'-NTR des PVX wurden intensiv bezüglich auf ihren Einfluss während der (+)-Strang RNA-Synthese untersucht. Kim \& Hemenway (1996) konnten zeigen, dass die Deletion von mehr als 12 nt eines 5'-terminalen Bereichs dazu führte, dass die (+)-Strang RNA-Akkumulation in Protoplasten signifikant abnahm. Ein konserviertes Octanukleotid Element, AACUAAAC (nt 4-11), wurde am 5'-Ende des Genoms nachgewiesen, welches die (+)-Strang gRNA and sgRNA-Akkumulation in vivo während der ,long-distance“ RNA-RNA- Interaktionen mit anderen internen konservierten Elementen des Genoms reguliert (Kim \& Hemenway, 1997 und 1999). Miller et al. (1998 und 1999) konnte in der 5'-NTR des PVX Genoms zwei „stem-loop“ Strukturen SL1 und SL2 nachweisen. Es konnte eine Vielzahl an „cis-acting“-Elementen in dem SL1 nachgewiesen werden. Weiterhin konnte Miller et al. (1997) in Protoplasten zeigen, dass ein Terminal gelegener „tetraloop“ (TL) GAAA, notwendig ist für die (+)-Strang gRNA und sgRNA-Akkumulation. Darüber hinaus ist die Struktur und spezifische Sequenz des intern gelegenen „loop“ C (LC) und C-C ,mismatch“ im ,stem“ C wichtig für die PVX (+)-Strang RNA-Synthese. Eine kürzlich durchgeführte Studie des Bamboo mosaic virus (BaMV), Genus Potexvirus zeigte, dass fünf Ribonukleotide (UUUUC) am 3'-Ende der (-)-Strang RNA für die Initiierung der (+)-Strang RNA in vitro notwendig sind (Lin et al., 2005). Im Pflanzenvirus Brome mosaic virus (BMV) konnte eine „stem-loop“-Struktur im 5'-Ende der BMV RNA2 nachgewiesen werden, welche mit dem viralen BMV Protein 1 interagierte und dazu führte, dass die RNA2 einen membranassoziierten RdRp-Komplex ausbildete (Chen et al., 2001). 


\subsection{2 „Cis-acting“ RNA-Elemente in der 3'-NTR}

Im Allgemeinen wird die (-)-Strang RNA-Synthese von der 3'-NTR des (+)-Strang RNATemplates initiiert. (+)-Strang RNA-Viren haben verschiedene 3'-Enden, eingenommen eines „polyA-tails“, „tRNA-like“-Strukturen (TLS) und „stem-loop“-Strukturen (zusammengefasst in Batten et al., 2003; Verchot-Lubicz et al., 2007). Die Sequenz und Strukturelemente in der 3'-NTR stellen somit die Promotorbindungsstelle für die (-)-Strang RNA-Synthese dar (Hemenway \& Lommel, 2000).

Bancroft et al. (1991) konnten als erste am Cymbidium mosaic virus (CymMV), Genus Potexvirus nachweisen, dass die Hexanukleotid-Elemente in der 3'-NTR von gRNA in allen Potexviren konserviert auftraten. Enzymatische und chemische Untersuchungen zeigten, dass diese Hexanukleotid-Elemente von PVX und BaMV in „loop“- Strukturen lokalisiert sind (Cheng \& Tsai, 1999; Pillai-Nair et al., 2003). Die rekombinante BaMVReplikase (C-Terminus wurde in E. coli exprimiert), kann mit dem Hexanukleotid im „loop“ interagieren (Cheng \& Tsai, 1999). Pillai-Nair et al. (2003) wiesen nach, dass in Tabakprotoplasten das Hexanukleotid essentiell für die RNA-Replikation war, d.h. eine Deletion von $10 \mathrm{nt}$, inbegriffen des Hexanukleotids, führte somit $\mathrm{zu}$ einer nicht-stattfindenden Akkumulation der (-)- und (+)-Strang RNA in Tabakprotoplasten.

An das Hexanukleotid Element grenzt stromabwärts ein acht Nukleotid U-reiches Sequenzmotiv (UAUUUUCU), welches als essentiell für die Potexvirus RNA-Stabilität, Translation und/oder Replikation nachgewiesen wurde. Das zelluläre Wirtsprotein bindet speziell an diese U-reiche Sequenz in vitro (Sriskanda et al., 1996). Die zielgerichtete Mutagenese zeigte, dass diese Wirtsproteinbindung abhängig war von U-reichen Nukleotid-Elementen. Die Identität solcher Wirtsproteine ist jedoch noch unbekannt. In PVX befinden sich wahrscheinlich die meisten U-reichen Sequenzen im SL2 und das letzte C-Nukleotid im „stem“. Mutageneseuntersuchungen zeigten ebenfalls, dass die letzte UCSequenz stärker sensitiv bezüglich der (-)-Strang RNA-Akkumulation in vivo war, und ebenso eine Deletion der U-reichen Elemente des PVX die (-)-Strang RNA-Akkumulation in vivo negativ beeinflusst (Sriskanda et al., 1996; Pillai-Nair et al., 2003).

Der „polyA-tail“ (Polyadenylisierungsschwanz) am 3'-Ende übernimmt ebenfalls eine wichtige Rolle innerhalb des Genus Potexvirus. Cheng et al. (2002) zeigten, dass die Replikase/RdRp die (-)-Strang RNA-Synthese innerhalb des ,polyA-tails“ initiiert, höchstwahrscheinlich 7-10 Aminosäurereste entfernt vom 3'-Terminus des BaMV in vitro. Bereits durchgeführte Untersuchungen mit PVX (Pillai-Nair et al., 2003) konnten die 
absolute Notwendigkeit des ,polyA-tails“ für die (-)- und (+)-Strang RNA-Akkumulation in Protoplasten nachweisen.

Es ist bekannt, das RNA-Strukturelemente in der 3'-NTR für die Replikation von Potexviren von hoher Bedeutung sind. Pillai-Nair et al. (2003) konnte anhand von in silico und enzymatischen Analysen drei „stem-loop“-Strukturen (SL1, SL2 und SL3) im 3'-NTR nachweisen. Eine Vielzahl an Studien zeigte, dass die Formation von SL3 essentiell für eine optimale PVX-Replikation in vivo ist, wobei die SL1 und SL2 Strukturen weniger notwendig sind. Stattdessen sind Sequenz-Zusammensetzungen in dieser Region für die PVX RNA-Akkumulation von Bedeutung.

\subsection{Replikation des Potato virus $X$ (PVX)}

Wie bereits erwähnt, ist die Replikase oder auch RNA-abhängige RNA-Polymerase (RdRp) genannt, für die Replikation des Potato virus $X$ (PVX) verantwortlich und wird als ORF 1 direkt von der genomischen RNA translatiert. Die am 3'-Ende gelegene nicht-translatierte Region (NTR) des Potexvirusgenoms umfasst, wie bereits in Kapitel 1.2.3.2 erwähnt, ein Uracil-reiches Motiv (konserviertes Hexanucleotid), das als Erkennungssignal für die Initiierung der Replikation dient (White et al., 1992). Stromabwärts dieses Sequenzmotivs befindet sich ein weiteres acht Nukleotide langes Motiv, das so genannte Uridin-reiche Motiv, welches an der Replikation beteiligt ist, wobei eine essentielle Rolle der Bindung von Wirtsproteinen zukommt, die scheinbar für die Lokalisierung des Replikase-Komplexes sowie für die RNA-Stabilität entscheidend sind (Sriskanda et al., 1996; Batten et al., 2003). Kim et al. (2002) konnten bezüglich PVX ergänzend zeigen, dass die Bindung der 5'-NTRs über das Uridin-reiche Sequenzmotiv an ein $54 \mathrm{kDa}$ großes Wirtsprotein für die Replikation von großer Bedeutung ist.

\subsection{Wirtsproteine und Replikation der „alpha-like“ Pflanzenviren}

Die Beobachtung, dass die meisten Viren eine limitierte Auswahl an Wirten besitzen, lässt darauf schließen, dass spezifische Proteine an der viralen Replikation beteiligt sind. Eine weitere Studie zeigte, dass lediglich die gereinigte Replikase/RdRp, d.h., ohne zelluläre Proteine, gewöhnlich inaktiv oder nicht Template-spezifisch ist und damit ebenfalls die Beteiligung von Wirtsfaktoren während der viralen Replikation bestätigte (zusammengefasst in Lai, 1998; van der Heijden \& Bol, 2002). Quadt et al. (1993) 
identifizierten in ihrem Experiment ein Protein, das mitgereinigt wurde mit dem BMV Replikase/RdRp-Komplex als p41 Untereinheit des eukaryotischen Translationsinitiationsfaktors 3 (eIF-3). Die Existenz des kompletten eIF-3 oder der p41 Untereinheit bewirkte einen dreifachen Stimulationseffekt in Bezug auf die (-)-Strang RNAAkkumulation in vitro. Eine weitere Untersuchung belegte die Existenz einer weiteren eIF-3 Untereinheit in jedoch infizierten Tobacco mosaic virus (TMV) Tomatenpflanzenextrakten, die homolog zu einem Hefe RNA-Bindungsprotein, dem so genannten GCD10, ist (Osman \& Buck, 1997). Taylor \& Carr (2000) konnten zeigen, dass GCD10 mit der Methyltransferase Domäne der TMV-Replikase interagieren kann, wobei durch Antikörper gegen GCD10 die TMV-Replikase Aktivität in vitro inhibiert wird. Es scheint somit, dass die eIF-3-Untereinheit eine Funktion während der viralen Replikation übernimmt. Auf der anderen Seite können verschiedene 3'-terminale Sequenzen der viralen RNA, z.B. der „polyA-tail“ oder „,tRNA-like“- Strukturen (TLS's), Bindungsstellen für unterschiedliche Wirtsproteine liefern. Innerhalb einiger Pflanzenviren bindet EF-1 $\alpha$ ebenfalls direkt an genomische RNAs mit 3'-TLS (zusammengefasst in Lai, 1998).

Die prokaryotischen Translationsfaktoren EF-Ts und EF-Tu, die äquivalent zu EF-1 $\alpha$ sind, sind fest mit dem Bakteriophagen $Q \beta$ Polymerasekomplex verbunden. Bakteriophage $Q \beta$ ist das einzige Virus, für das die komplette Zusammensetzung des Replikasekomplexes bekannt ist.

Bezüglich Potato virus $X$ konnten Kim et al. (2002) zeigen, dass ein $54 \mathrm{kDa}$ zelluläres Protein an eine 5'-terminale Sequenz der PVX RNA bindet, was wiederum für die RNA-Akkumulation notwendig ist.

Wie bereits erwähnt, scheint die Replikation von (+)-Strang RNA-Viren ein membranassoziierter Prozess an entweder vorhandenen oder induzierten zellulären Wirtsmembranen $\mathrm{zu}$ sein. Generell ist in vielen Virusreplikationssystemen die Assoziierung des Replikase/RdRp-Komplexes mit Wirtsmembranen für die in vitro RNASyntheseaktivität notwendig (De Graff \& Jaspars, 1994). Doronin \& Hemenway (1996) konnten als erste nachweisen, dass der membranassoziierte PVX Replikase/RdRp Pflanzenextrakt von PVX-infizierten Nicotiana benthamiana Pflanzen, RNA-Syntheseaktivität mit einem endogenen Template aufwies. 


\section{Variation und Evolution von Pflanzenviren}

\subsection{Mechanismen der Virusevolution}

Für die Evolution der Viren sind verschiedene Mechanismen verantwortlich, wie das segmentierte „Reassortment“ (Kapitel 4.6), die Evolution der Pflanzen, die ständigen Änderungen der Umweltbedingungen und der dadurch hervorgerufene Selektionsdruck. Allen vorangestellt sind jedoch die Mutation sowie die homologe und nicht homologe Rekombination als die treibenden Kräfte der Evolution von Pflanzenviren zu bezeichnen (zusammengefasst in Domingo et al., 1988; Holland, 1992; Morse, 1994; Gibbs \& Cooper, 1995; Domingo \& Holland 1997; Roossinck, 1997; García-Arenal et al., 2001 und 2003). Die Rekombination bei Viren ist analog zu der Rekombination während der Meiose, und das „Reassortment“ ist analog zu dem chromosomalen „Reassortment“ während der sexuellen Fortpflanzung (Roossinck, 1997). Sequenzuntersuchungen verschiedener Virusgruppen (RNA- sowie DNA-Viren) zeigten, dass sich diese Mechanismen unterschiedlich auf Viren auswirken können und somit auch zu einer Vielfalt an Viren bzw. zu einer genetischen Variation beigetragen haben (Domingo et al., 1988; Holland, 1992; Domingo \& Holland, 1994). Die genetische Variation oder auch Variabilität ist die Basis der Adaption an wechselnde Umwelteinflüsse (modifikatorische Variabilität) und dadurch ebenfalls eine treibende Kraft der Evolution (Domingo \& Holland 1997; Roossinck, 1997; García-Arenal et al., 2001 und 2003). All diese Mechanismen wurden für Pflanzenviren untersucht, wobei wenig über den Mechanismus der Mutation und Selektion, der für die Fitness verantwortlich ist, bekannt ist.

\subsection{Mutation: Mutationsrate und -frequenz}

Im Allgemeinen definiert eine Mutation eine sprunghafte, spontane oder künstlich erzeugte genetische Veränderung des Genotyps (erbliche Veränderungen in der Basensequenz der Nukleinsäure oder Anzahl der Nukleotide während der Replikation), wobei sich in einer Population die Nachkommen in ihren Genotypen unterscheiden (genetische Variabilität) (Domingo \& Holland 1997; García-Arenal et al., 2003). Diese auftretende Mutation kann aber auch den Phänotyp eines Nachkommens verändern. Hierbei ist wichtig, die Mutationsfrequenz von der Mutationsrate zu unterscheiden (Domingo et al., 1999; GarcíaArenal et al., 2003). Die Mutationsrate ist die Häufigkeit, mit der eine bestimmte Mutation innerhalb eines Genoms auftritt (Anzahl der Mutationsereignisse). Hingegen wird die 
Mutationsfrequenz als der Anteil bzw. die Häufigkeit definiert, mit der eine bestimmte Mutation in einer Population nachweisbar ist. Im Vergleich zu der Mutationsfrequenz basiert somit die Mutationsrate auf einem festgelegten Wert. Drake \& Holland (1999) haben den Zusammenhang dieser Ereignisse näher charakterisiert. Die Mutationsfrequenz ist entscheidend bei Untersuchungen der Variation und Evolution. Die meisten Studien wurden in vitro untersucht (Domingo \& Holland 1997), wenig Evidenz besteht in Bezug auf in vivo Untersuchungen (Lewis, 1999). Die Mutationsfehlerrate hängt von der Art der Replikation, der Zusammensetzung der Nukleotidsequenz und umweltbedingten Faktoren ab (Steinhauer et al., 1992; Hansen et al., 1997; Whittle \& Johnston, 2006). Die Mutationsrate der RNA-abhängigen RNA-Polymerase (RdRp) beträgt bei tierischen RNAViren $10^{-4}$, d.h., die RdRp tauscht ein Nukleotid in 10.000 Nukleotiden aus bzw. bei jeder 10. kb liegt ein Fehler pro Genom vor (Domingo \& Holland, 1994). Roossinck (1997)

stellte die Vermutung auf, dass die Mutationsrate der viralen RdRp innerhalb der Pflanzenviren ähnlich hoch ist wie bei tierischen Viren. Palukaitis \& Roossinck (1995) zeigten, dass die Mutationen gewöhnlich nicht gleichmäßig über das Genom verteilt auftreten, sondern als so genannte „hot spots“, d.h., sie kommen konzentriert an einigen Stellen vor. Generell gilt jedoch, dass nicht jede Mutante eine Grundlage für eine neue Variante bildet.

\section{RNA-Rekombination}

Innerhalb der RNA-Viren bezeichnet die Rekombination die Neuanordnung genetischer Information (Erbanlagen) durch kovalente Verbindungen zweier parentaler RNA-Moleküle zu einer neu synthetisierten RNA-Rekombinante. Die Rekombination der Viren kann, wie bereits erwähnt, mit der Rekombination während der Meiose eukaryotischer Zellen verglichen werden. In Anlehnung an das genomische „Reassortment“ segmentierter Genome oder dem Auftreten von Punktmutationen, liefert die RNA-Rekombination einen wichtigen Mechanismus, der zu Veränderungen des Virusgenoms führen kann. Durch diesen Mechanismus können schließlich neue chimäre Viren oder funktionelle Genome mutierter oder defekter Viren erzeugt werden (zusammengefasst in White \& Morris, 1995; Nagy \& Bujarski, 1996; Simon \& Nagy, 1996; Bujarski, 1999; Masuta, 2002). Aufgrund dieser Merkmale übernimmt die RNA-Rekombination wahrscheinlich eine essentielle Rolle bei der Genomreparatur, viralen Adaption und Evolution (Dolja \& Carrington, 1992; Lai, 1992; zusammengefasst in Simon \& Bujarski 1994; Aranda et al., 1997; MacFarlane, 
1997; Roossinck, 1997; Aaziz \& Tepfer, 1999a). Während der evolutionären Variation von Pflanzenviruspopulationen ist folglich neben der Mutation die RNA-Rekombination von großer Bedeutung (García-Arenal et al., 2001 und 2003), wobei sie, wie bereits erwähnt, Fehler ausgleichen kann, die durch die Neustrangsynthese der Replikase/RNA-abhängigen RNA-Polymerase (RdRp) während der Genomreplikation auftreten können (Roossinck, 1997). Die Mutationsrate ist somit innerhalb der RNA-Viren sehr hoch, bedingt durch die fehlende Korrekturlesefähigkeit der Replikase/RdRp (Domingo et al., 1999 und 2002). Im Kontext mit einer häufigen Replikation, führt diese fehlende Korrekturlesefähigkeit der Replikase/RdRp zu einer dynamischen Population an Viren (Quasi-Spezies) mit vielen Sequenzvaraitionen. Diese Population steht unter dem ständigen Selektionsdruck, ein funktionelles Genom beizubehalten (Holland \& Domingo, 1998).

\subsection{Quasi-Spezies}

Das Modell der Quasi-Spezies wurde 1971 von Eigen entwickelt und beschreibt die Evolution eines geschlossenen Systems von selbstreproduzierenden RNA- oder DNAMolekülen ohne Hilfe von Enzymen, in erster Linie mit dem Ziel, den Ursprung des Lebens zu verstehen. Diese molekulare Evolutionstheorie verdeutlicht die Darwinsche Evolutionstheorie (Darwin, 1988) mit Mutation und Replikation als parallele chemische Abläufe und stützt sich auf die ursprünglich quantitative Untersuchung von Selektionsvorgängen in Populationen mit asexueller Vermehrung (Schuster, 1999). Die Mutation und Replikation wird bei diesem Modell in einem abstrakten Raum aller Nukleotidsäuresequenzen, dem so genannten Sequenzraum, dargestellt. Hierbei steht im Hintergrund, dass eine kombinatorische Vielfalt von Nukleotidsäuresequenzen entsteht. Die Populationen werden heterogen bei ausreichend hohen Mutationsraten und weisen allzeit mehrere Genotypen auf. Eigen et al. (1989) zeigte, dass sich in den Populationen, stationäre, d.h., eine von der Zeit unabhängige Mutantenverteilung, so genannte QuasiSpezies ausbilden, die wiederum das genetische Reservoir für die asexuelle Vermehrung bilden (Eigen \& Schuster, 1979). Es konnte mit dieser Evolutionstheorie gezeigt werden, dass die Mutationsrate nicht beliebig erhöht werden kann, ohne dass die Stationarität der Mutantenverteilung verloren geht (Schuster, 1999). Es gibt somit eine kritische Fehlerrate/schwelle der Mutantenverteilung. Wird diese Fehlerschwelle überschritten, ist die Population nicht mehr in der Lage, die genetische Information korrekt weiterzugeben und folglich bricht der Vererbungsprozess zusammen, d.h., es werden kontinuierlich so viele 
neue Mutanten erzeugt, dass die Fitness der besten als Mastersequenz (Spektrum von Mutanten) bezeichnete Variante nicht mehr ausreicht, um ihren Fortbestand in den folgenden Generationen zu gewährleisten (Schuster, 1999). Die Mutantenhäufigkeit innerhalb der Quasi-Spezies wird schließlich durch ihre Verwandtschaft bzw. ihren Bezug zur Mastersequenz sowie durch ihre eigene Fitness bestimmt. Anhand von RNA-Viren wurde die so genannte Fehlerschwelle experimentell in vivo (zusammengefasst in Domingo \& Holland, 1997) und mittels replizierender RNA-Moleküle in vitro (Biebricher \& Gardiener, 1997) erforscht. Drake (1993) zeigte, dass als ein Beispiel für RNA-Viren ihre Genomlänge in Betracht gezogen werden kann, die ungefähr der wechselseitigen Fehlerrate der Replikation entspricht. Die Viren sind dabei einem großen Selektionsdruck durch die Wirtsorganismen ausgesetzt, auf den sie wiederum durch maximale Variabilität bzw. Anpassung reagieren (Domingo \& Holland, 1997). Domingo et al. (1985) befasste sich erstmals mit dem allgemeinen Konzept der Quasi-Spezies viraler RNA hinsichtlich der Heterogenität von Nukleinsäuren im Bereich der Virologie. Eine Vielzahl an RNAViren ist somit heterogen und besteht aus einer Gruppe von Viren mit ähnlichen bzw. nahe verwandten Genomen, die unterschiedlich in einem oder mehreren Nukleotiden sind.

\subsection{Natürliche Rekombination innerhalb der Viren und subviraler Spezies}

Die natürliche Rekombination wird als RNA-Rekombination unter Einfluss von geringem Selektionsdruck definiert. Beispiele hierfür sind die Tobraviren, bei denen durch Sequenzuntersuchungen und angemessene in silico Analysen, Rekombinationen nachgewiesen werden konnten. Das 3'-Ende der RNA2 eines Tobacco rattle virus (TRV) Isolats war identisch mit dem 3'-Ende der RNA1 desselben Virus. Es konnte jedoch auch zwischen zwei Tobraviren unterschiedlichen Isolats eine Rekombination nachgewiesen werden (Robinson et al., 1987; MacFarlane, 1997). Insbesondere die RNA1 (oder RNA2) einiger TRV-Isolate wurde als Rekombinante zum Pea early browning virus (PEBV) nachgewiesen. RNA-Rekombination ist nicht nur auf Viren beschränkt, sondern kommt auch in einigen subviralen RNA-Molekülen wie Viroiden und Satelliten-RNAs vor. Durch paarweise Vergleiche von Nukleotidsequenzen konnten natürliche Chimären zwischen verschiedenen Viroiden nachgewiesen werden. Ein Beispiel hierfür ist das Tomato apical stunt viroid (Pospoviroid), welches vermutlich eine Rekombinante des Potato spindle tuber viroid-like- und eines Citrus exocortis viroid-like Viroids ist (Spence \& Barbara, 2000). Des Weiteren ist das Australian grapevine viroid (Apscaviroid) ein Beispiel für eine 
RNA-Rekombinante aus diesen genannten Viroiden (Rezaian, 1990; Spence \& Barbara, 2000; Elleuch et al., 2002). Im Gegensatz zu den Viroiden unterstützt wenig Evidenz die Vorstellung, dass natürliche Satelliten-RNAs tatsächlich aus der RNA-Rekombination hervorgehen. Ein Beispiel hierzu sind jedoch die Satelliten-RNAs des Genus Carmovirus, Turnip crinkle virus (TCV). TCV besitzt Satelliten-RNAs unterschiedlicher Größe, welche auf TCV für ihre Replikation angewiesen sind (Cascone et al., 1990). Offenbar ist eine Satelliten-RNA (sat C) aus Rekombinationsereignissen zwischen einer anderen SatellitenRNA (sat D) und der genomischen RNA von TCV hervorgegangen. Satelliten-RNAs sind lineare RNA-Moleküle, die während der Replikation in RNA-Doppelstrangform vorkommen können. Sie sind stets assoziiert mit dem Virus (Helfer-Virus), welches dann die Replikase/RNA-abhängige RNA-Polymerase (RdRp) für die Replikation bereitstellt (Roossinck et al., 1992). „Defective interfering RNAs“ (DI RNAs) stellen eine kleinere abgeleitete Form des elterlichen (Helfer) Virusgenoms durch Sequenzdeletion(en) dar (Cheng \& Nagy, 2003). Es wird angenommen, dass die Sequenzdeletion(en) während der DI RNA Formation die Konsequenz der viralen Replikase ist, die das Template wechselt, und dabei stufenweise die Deletionen des Virusgenoms auftreten können. Gewöhnlich konkurrieren die DI RNAs mit dem intakten Virusgenom und sind Ursache für schwächere Symptome. Interferieren sie nicht mit dem elterlichen Virus, werden sie als „Defective RNAs“(D RNAs) bezeichnet.

\subsection{Vorkommen der RNA-Rekombination innerhalb verschiedener Virusfamilien}

Im Allgemeinen wurde RNA-Rekombination vor allem für Vertreter verschiedener Familien von RNA-Viren mit einem Genom positiver Polarität [(+)-Strang Viren] (z.B. King et al., 1987; Lai, 1992; Strauss \& Strauss, 1994; Meyers \& Thiel, 1996; Agol, 1997; Nagy \& Simon, 1997) und negativer Polarität [(-)-Strang Viren] untersucht (z.B. Khatchikian et al., 1989; Chare et al., 2003). Es konnte jedoch auch Rekombination in RNA-Viren mit einem ambisense Genom (positive- und negative Polarität) nachgewiesen werden (z.B. Finke \& Conzelmann, 1997; Wu \& Brian, 2007). Des Weiteren wurde RNARekombination durch verschiedene Studien teils im Detail für einige bei Tier und Mensch (z.B. Coronaviren, Alphaviren, Aphtoviren, Polioviren: Ledinko, 1963; Cooper, 1977; King et al., 1982; Kirkegaard \& Baltimore, 1986; Makino et al., 1986; Keck et al., 1987; Jarvis \& Kirkegaard, 1992; Raju et al., 1995), Bakterien (z.B. Qß-Phage: Munishkin et al., 1988; Brown \& Gold, 1996) und Pflanzen vorkommenden Viren erforscht. Die RNA- 
Rekombination innerhalb der Pflanzenviren wird im nächsten Absatz dieser Arbeit gesondert beschrieben.

\section{Beispiele für Rekombination innerhalb der RNA-Pflanzenviren}

RNA-Rekombination innerhalb der Pflanzenviren ist ein weit verbreitetes Phänomen und wurde bereits in einigen Pflanzenvirengruppen und unterschiedlichsten Genera nachgewiesen (Alejska et al., 2001; Chare \& Holmes, 2006). Experimentelle in vivo Evidenz wurde somit für eine Anzahl von unterschiedlichen Virusspezies geliefert (Huisman et al., 1989; White \& Morris, 1994; Nagy \& Simon, 1997; Adair \& Kearney, 2000; Canto et al., 2001). Beispiele hierzu sind die Bromoviren (Bujarski \& Kaesberg, 1986; Allison et al., 1996; Nagy \& Bujarski, 1996; Alejska et al., 2005), Tobraviren (Robinson et al., 1987; MacFarlane, 1997), Tombusviren (White \& Morris, 1994; Panavas \& Nagy 2003), Tobamoviren (Shirako \& Brakke, 1984), Carmoviren (Cascone et al., 1990 und 1993; Zhang et al., 1991), Cucumoviren (van der Kuyl et al., 1991; Fraile et al., 1997), Nepoviren (Rott et al., 1991; Le Gall et al., 1995), Hordeiviren (Edwards et al., 1992) und Potyviren (Cervera et al., 1993; Gal-On et al., 1998; Varrelmann et al., 2000). Eine wichtige Studie zur Rekombination innerhalb der unterschiedlichen Pflanzenvirengruppen und -familien wurde von Aaziz \& Tepfer (1999a) zusammengefasst und publiziert.

\subsection{Klassifizierungen der RNA-Rekombination}

Im Allgemeinen können zwei Varianten für eine Klassifizierung der RNA-Rekombination in Betracht gezogen werden. Zum einen die ältere nach Lai (1992), und zum anderen die neuere Variante der RNA-Rekombinationsklassifizierung nach Nagy und Simon (1997).

\subsubsection{Klassifizierung der RNA-Rekombination nach Lai (1992)}

Lai (1992) kategorisierte die RNA-Rekombination nach der Sequenzhomologie der rekombinierenden RNA-Moleküle und der entstandenen „crossover sites“ (Überkreuzungsbzw. Übergangsstellen) in drei Klassen. Hierbei wird zunächst zwischen homologer Rekombination [HR; zwischen verwandten parentalen RNA-Strängen, die zumindest in den beteiligten Bereichen bzw. Übergangsstellen (Nukleotidsequenzen) sehr ähnlich oder identisch (homolog) sind] und nicht homologer Rekombination (NHR; zwischen nicht 
verwandten parentalen Sequenzen) unterschieden. Bei der HR spricht man weiterhin von präziser oder unpräziser bzw. aberranter homologer Rekombination (AHR), je nach Beschaffenheit bzw. Zusammensetzung der Nukleotidsequenz an den homologen Übergangsort (,,crossing-over“) gegenüber den parentalen Sequenzen. Im Detail lässt somit die präzise Rekombination Veränderung, d.h. Mutationen im homologen Sequenzbereich nicht zu, wobei die nicht präzise (aberrante) Rekombination an der homologen Übergangsstelle Divergenz in den Nukleotidsequenzen (Mutationen) toleriert, z.B. in Form von Deletionen und Insertionen. Im Allgemeinen kann die RNA-Rekombination zwischen zwei Bereichen desselben RNA-Moleküls (intramolekular) oder zwischen zwei separaten RNA-Molekülen (intermolekular) stattfinden.

\subsubsection{Klassifizierung der RNA-Rekombination nach Nagy und Simon (1997)}

Die neuere bzw. alternative Charakterisierung nach Nagy \& Simon (1997) bezieht den Mechanismus der Rekombination, kombiniert mit den Eigenschaften der Rekombinationsprodukte (Rekombinanten), in die Klassifizierung der Rekombination mit ein. Die Klassifizierung erfolgt jedoch wie bei Lai (1992) in drei Klassen (Abb. 3).

Klasse 1 beschreibt hierbei die „Similarity-Essential“ Rekombination (SER). Diese Art der Rekombination ist von Sequenzhomologien der parentalen RNAs abhängig, wobei präzise und unpräzise Rekombinanten entstehen, ähnlich $\mathrm{zu}$ den homologen oder aberranten Rekombinanten nach Lai's Klassifizierung. Präzise Rekombinante weisen an der Übergangsstelle (,crossing-over“) keine Änderungen (Deletionen oder Insertionen von Nukleotiden) der Sequenz, verglichen zu den parentalen RNAs, auf. Hingegen weisen unpräzise Rekombinanten abweichende Sequenzen innerhalb der Sequenzhomologie (,sequence similarity“) auf, einschließlich Mutationen, Deletionen und Insertionen.

Klasse 2 wird als „Similarity-Nonessential“ Rekombination (SNER) bezeichnet. Hierbei ist eine Sequenzhomologie keine Voraussetzung für eine Rekombination. Diese Art der Rekombination wird durch primäre bzw. sekundäre Eigenschaften der RNA-Struktur bestimmt, z.B. Sekundärstrukturen, subgenomischer Promotor, Heteroduplexstrukturen zwischen parentalen RNAs und Replikase/RdRp Bindungsstellen (zusammengefasst in Chetverin, 1999; Figlerowicz, 2000).

Klasse 3 kennzeichnet die „Similarity-Assisted“ Rekombination (SAR), die ebenfalls durch Sequenzhomologien begünstigt wird. Diese Art der Rekombination kombiniert Eigenschaften aus den Klassen 1 und 2. Hierbei müssen neben der Sequenzhomologie 
zwischen den parentalen RNAs auch Eigenschaften der RNA-Struktur, die jedoch nur auf einer der parentalen RNAs vorkommen muss, vorhanden sein. Als Beispiel hierfür sei genannt, dass für eine solche Art der Rekombination auf nur einer der RNAs eine so genannte „motif1-hairpin“ Struktur vorhanden sein muss, um letztlich die Rekombination zu induzieren (zusammengefasst in Nagy \& Simon, 1997).

Mehrere Studien belegten für verschiedene RNA-Viren, dass eine lokale Basenpaarung (Abb. 3; Klasse 1) zwischen wachsendem RNA-Strang und parentalem RNA-Strang 1 den replikativen „template switch“ sowohl bei homologer als auch bei nicht homologer RNA-Rekombination erleichtert (White \& Morris, 1994; Nagy \& Bujarski, 1995; Nagy \& Simon, 1997). Weiterhin konnte gezeigt werden, dass auch eine Ausbildung von antiparallelen Heteroduplexstrukturen zwischen zueinander inversen Sequenzbereichen der parentalen RNA-Stränge die RNA-Rekombination positiv beeinflussen kann (Nagy \& Simon, 1997; Figlerowicz, 2000; Gmyl \& Agol, 2005), wobei ein replikativer als auch ein nicht-replikativer Mechanismus zugrunde liegen kann. Für eine Begünstigung der replikativen RNA-Rekombination (Abb. 4) können ebenfalls Sequenzmotive herangezogen werden, die entweder über ein Pausieren der viralen Transkription am parentalen RNAStrang 2 (z.B. Ausbildung einer Sekundärstruktur oder einen erhöhten Anteil an AUElementen) oder eine forcierte Reinitiierung der viralen RNA-Strang-Synthese am parentalen RNA-Strang 1 (z.B. durch virale promotorähnliche Sequenzen) (Nagy \& Bujarski, 1997; Nagy et al., 1999) entstehen. 


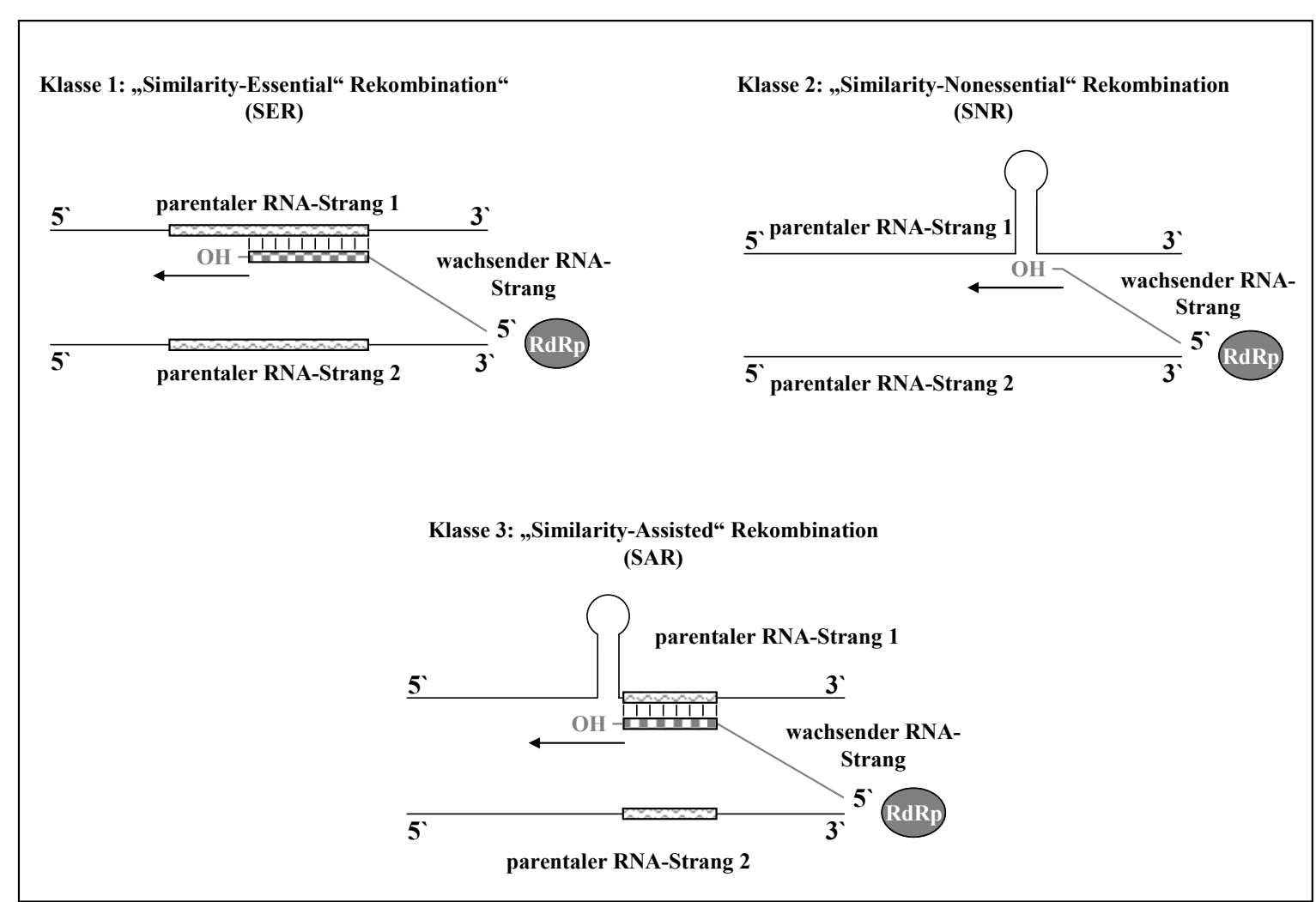

Abb. 3: Die 3 Klassen der RNA-Rekombination (modifiziert nach Nagy \& Simon, 1997). Die parentalen RNA-Stränge 1 und 2 sind hier jeweils mit homologem Sequenzbereich dargestellt. Die schwarzen Pfeile symbolisieren die Richtung der Replikase bzw. die Generierung des wachsenden RNA-Stranges. Der parentale RNA-Strang 1 weist in Klasse 1 und 2 eine Eigenschaft der allgemeinen RNA-Struktur auf, hier in Form eines ,stem-loop“.

\subsection{Putative Mechanismen der RNA-Rekombination}

Intermolekulare RNA-Rekombinationen, ebenso wie Deletionen und Vervielfältigungen, können theoretisch durch zwei sich stark voneinander unterscheidende Mechanismen, replikativer und nicht-replikativer Rekombination, ablaufen (Gmyl \& Agol, 2005). Im Wesentlichen sind diese beiden Mechanismen wahrscheinlich für die Entstehung rekombinanter RNA-Moleküle verantwortlich: Zum einen der replikative „template switch“ der viralen RNA-abhängigen RNA-Polymerase, und zum anderen die nicht replikative Spaltung und Ligation von RNA, welche als „breakage and ligation“ bezeichnet wird (Abb. 4). Das Replikase/RdRp vermittelte „template switch“ Modell wird jedoch häufiger postuliert. In Anlehnung an das Modell des replikativen „template switch“ wird vermutet, dass in den meisten Fällen die Synthese mit der komplementären (-)-Strang RNA auf einem der parentalen RNA-Moleküle (1) beginnt und auf einem weiteren RNA- 
Molekül (2) beendet wird. Der hier neu synthetisierte RNA-Strang wird als primäre Rekombinante bezeichnet. Während der Synthese des neu wachsenden RNA-Stranges (Tochterstranges) von einem parentalen RNA-Molekül (1) zum anderen (2), sind unterschiedliche Mechanismen möglich. Der neu-synthetisierte RNA-Strang kann von dem einen parentalen RNA-Molekül (1) abgezogen bzw. abgetrennt werden als Ergebnis einer frühzeitigen Terminierung und kann im Anschluss daran mit oder auch ohne Hilfe der Replikase/RdRp auf das Template des anderen parentalen RNA-Moleküls (2) wechseln. Zahlreiche in vitro Studien an verschiedenen Virussystemen mit gereinigter Replikase/RdRp wurden etabliert, um die RNA-Rekombination (Parameter und Mechanismen) näher verstehen zu können. Diese Systeme beinhalten PflanzenInfizierende Viren wie Brome mosaic virus (BMV) und Cowpea clorotic mottle virus (CCMV), beide Genus Bromovirus (Allison et al., 1996; Figlerowicz et al., 1997 und 1998; Figlerowicz \& Bujarski, 1998; Alejska et al., 2005) und Mitglieder der Supergruppe 3, ,alpha-like“ Viren (Koonin \& Dolja, 1993; zusammengefasst in van der Heijden \& Bol, 2002). Tomato bushy stunt virus (TBSV), Genus Tombusvirus (Panavas \& Nagy, 2003) und Turnip crincle virus (TCV), Genus Carmovirus (Zhang et al., 1991; Cheng \& Nagy, 2003) sowie RNA-Bakteriophage Qß (Brown \& Gold, 1996) repräsentieren die Supergruppe II („,carmo-like“ Viren) Virusmodellsysteme. Tierinfizierende Virussysteme sind Polioviren (Jarvis \& Kirkegaard, 1992), z.B. Bovine viral diarrhea virus (BVDV) und Mouse hepatitis virus (Banner et al., 1990; Fu \& Baric, 1992). Diese experimentellen Systeme zusammen mit in vitro Rekombinationsassays (Kirgegaard \& Baltimore, 1986; Arnold \& Cameron, 1999; Kim \& Kao, 2001) geben Aufschluss über einen replikativen „template switch“ Mechanismus, der auf die Generierung rekombinanter RNA-Moleküle zurückzuführen ist (zusammengefasst in Gmyl \& Agol, 2005).

Das „breakage and ligation“ Modell postuliert hingegen den Bruch oder die enzymatische Spaltung einer oder beider parentaler RNA-Stränge, die anschließend durch Ligation zu einem rekombinanten RNA-Molekül neu zusammengefügt werden (Abb. 4). Bei diesem Modell handelt es sich um einen replikationsunabhängigen Mechanismus. Dieses Ereignis wurde jedoch bis dato nur in vitro nachgewiesen (z.B. Qß-Bakteriophage und Poliovirus: Chetverin et al., 1997; Aaziz \& Tepfer, 1999a; Chetverina et al., 1999; Gmyl et al., 1999 und Gmyl \& Agol, 2005). Es konnte allerdings der Nachweis einzelner rekombinanter RNA-Moleküle innerhalb dieser Studien erst durch die Anwesenheit eines vollständigen Replikase/RdRp-Gens (z.B. des Qß-Phagen) erfolgen; dies stellt somit ein grundsätzliches Problem für den generellen Nachweis von replikationsunabhängiger RNA-Rekombination 
dar. Hingegen konnten Gmyl et al. (2003) bereits zeigen, dass diese Form der Rekombination auch mit genomischen Poliovirus-Fragmenten, d.h. mit unvollständigem, geteilten RdRp-Gen nachweisbar waren.

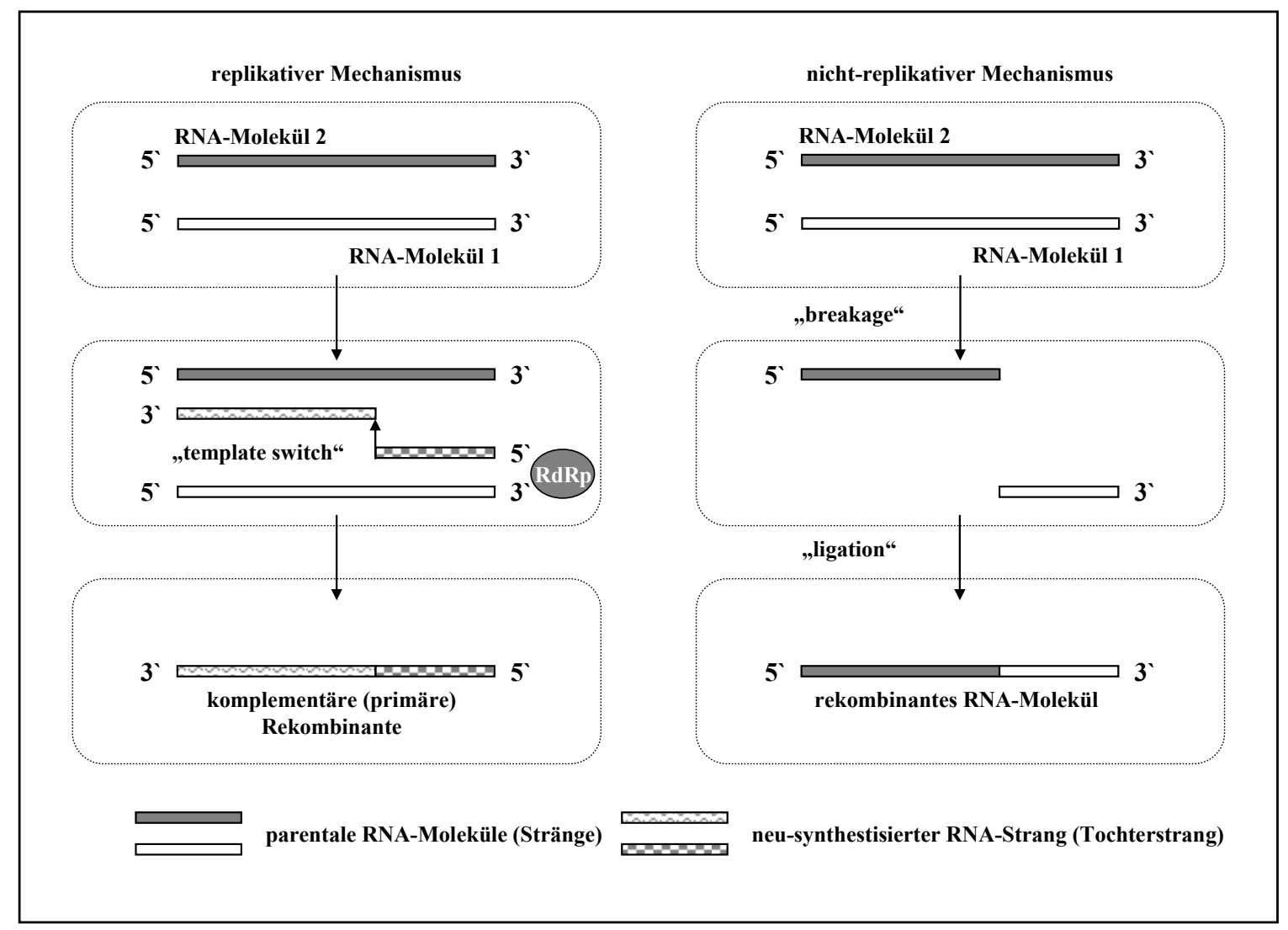

Abb. 4: Zwei putative Mechanismen der RNA-Rekombination (modifiziert nach Gmyl \& Agol, 2005): replikativer (,template switch“) Mechanismus: Während der Replikation oder auch RNA-Synthese findet die RNA-Rekombination statt, wobei die Replikase/RdRp auf dem einen parentalen RNA-Molekül 1 die Synthese eines neu entstehenden rekombinanten RNA-Moleküls initiiert und nach einer „Pause“ das Template, d.h. zum parentalen RNA-Molekül 2 wechselt, um dort die Neustrangsynthese zu beenden. Nichtreplikativer „breakage and ligation“ Mechanismus: Bei zwei zueinander homologen oder nicht homologen parentalen RNA-Molekülen (RNA1 und RNA2, bei der die Polarität positiv oder negativ sein kann), kommt es zu einem Bruch beider Rekombinationspartner, die durch Ligation zu einem rekombinanten RNA-Molekül neu zusammengefügt werden.

Im Allgemeinen konnten die Untersuchungen zahlreicher Studien unter hohem Selektionsdruck ein häufiges Auftreten rekombinanter Viren nachweisen, wobei hingegen bei geringem Selektionsdruck rekombinante Viren seltener nachgewiesen wurden (Huisman et al., 1989; White \& Morris, 1994; Nagy \& Simon, 1997 und 1998; Adair \& Kearney, 2000; Canto et al., 2001). Ein häufig benutztes System ist die Generierung bzw. 
Rekonstitution einer defekten Virusmutante und einer transgenen Pflanze, die das funktionelle Gen exprimiert. Hierbei besteht ein extrem hoher Selektionsdruck, um eine voll funktionsfähige Rekombinante zu erzeugen (z.B. Lommel \& Xiong, 1991; Gal et al., 1992). Infolgedessen setzen sich mit der Zeit Mutationen (z.B. Deletionen) durch, die entweder zur Wiederherstellung des ursprünglichen Wildtyps oder zu einer Verminderung der Virus-,,Fitness“ gegenüber dem ursprünglichen Wildtyps führen. Hierbei überleben nur die rekombinanten Viren, die am „fittesten“ sind. Dies ist eine Erklärung dafür, dass nur eine allgemeine Aussage über die Rekombinationsfrequenz, ein intaktes Virus mit Selektionsvorteil zu erzeugen, getroffen werden kann, nicht aber über die Rekombinationsrate (García-Arenal et al., 2001 und 2003). Allgemein konnten bisher nur selten rekombinante Viren unter Versuchsbedingungen mit geringem Selektionsdruck nachgewiesen werden. Hingegen Cervera et al., 1993; Revers et al., 1996; Glais et al., 2002 und Moreno et al., 2004 beschreiben bei Experimenten mit natürlichen Isolaten (geringer Selektionsdruck) eine Zunahme an rekombinanten Viren. Es konnten somit nicht nur in künstlich erzeugten Versuchsbedingungen rekombinante Viren nachgewiesen werden, bei denen ein artifiziell erzeugter hoher Selektionsdruck vorherrschte, sondern auch unter natürlichen Gegebenheiten. Cervera et al. (1993) und Glasa et al. (2002) demonstrierten bereits die natürliche Rekombination bei PPV zwischen verschiedenen Stämmen oder Isolaten. Innerhalb einiger Potyviren kann diese Zunahme sogar häufig beobachtet werden (Revers et al., 1996; Glais et al., 2002 und Moreno et al., 2004). Verschiedene Pflanzenviren können daher mit einer unterschiedlichen Häufigkeit rekombinieren.

Agol (1997) zeigte anhand von Picornaviren, dass die Häufigkeit der RNA-Rekombination (replikative sowie nicht replikative) von der Menge der involvierten RNA-Moleküle abhängt. Bei der replikativen Rekombination von Plusstrangviren ist die entstehende Konzentration an viralen Plussträngen höher als die der Minusstränge. Es kann folglich angenommen werden, dass die replikative RNA-Rekombination häufiger während der Minusstrang-Synthese erfolgt, im Vergleich zu der Plusstrang-Synthese (Kirkegaard \& Baltimore, 1986; Jarvis \& Kirkegaard, 1992; Lai, 1992; Agol, 1997). Für die nicht replikative RNA-Rekombination kann entsprechend postuliert werden, dass sie verstärkt zwischen den Plussträngen abläuft. 


\subsection{Pseudorekombination (,Reassortment"}

Die Pseudorekombination oder das „Reassortment" bezeichnet den Austausch von Genomkomponenten bzw. -segmenten bei Viren mit mehrteiligem Genom (Desselberger et al., 1978). Besteht das Genom eines Virus aus zwei oder mehr Segmenten, können hierbei die entsprechenden Segmente verschiedener Isolate einer Spezies und in den seltensten Fällen auch verschiedener Spezies sich neu kombinieren und so genannte Pseudorekombinanten bilden. Die Kombination von den entsprechenden Segmenten verschiedener Spezies lässt auf nicht-infektiöse Mischungen schließen, wobei auch unter Umständen Kombinationen von Segmenten von Isolaten einer Spezies nicht-infektiös sein können (Habili \& Francki, 1974; Hou \& Gilbertson, 1996; Salanki et al., 1997; Qui et al., 1998). Cucumoviren besitzen ein tripartites Genom, und unter experimentellen Bedingungen konnte eine Vielzahl an Pseudorekombinanten erzeugt werden, um die Funktion der viralen Proteine zu erforschen (Masuta et al., 1998; Aaziz \& Tepfer 1999b). Für Cucumber mosaic virus (CMV), Genus Cucumovirus führten phylogenetische Auswertungen dazu, dass die Pseudorekombination den Grund für die gegenwärtige Form lieferte. Zwischen zwei Cucumoviren konnte gezeigt werden, dass ein natürliches Cucumovirus Isolat genomische Segmente von beiden CMVs und Peanut stunt virus (PSV) beinhaltete (White et al., 1995). Weiterhin wurde berichtet, dass RNA 1 und 2 nicht austauschbar waren zwischen zwei Cucumoviren, während RNA 3 ausgetauscht werden konnte, was dadurch einen Rückschluss auf eine Pseudorekombinante zuließ. Generell findet hierbei nur ein Austausch der RNA 3 statt, wenn ein ausgedehnter homologer Bereich vorliegt, d.h. jedoch, dass bei diesen multipartiten Viren meist ein hoher Anteil an Kompatibilität vorliegt. Die Inkompatibilität der heterogenen Kombination von RNA 1 und 2 führte letztlich zu der Erzeugung der drei separaten Cucumovirus Spezies.

\section{Zielstellung dieser Arbeit}

Im Rahmen dieser vorliegenden Arbeit sollten die Replikations- und Rekombinationseigenschaften der Replikase oder RNA-abhängigen RNA-Polymerase (RdRp) des Potato virus X (PVX) im Detail charakterisiert werden. Die Arbeit teilte sich letztlich in zwei Schwerpunkte, zum einen in die Replikation, und zum anderen in die Rekombination bezogen auf Potexviren.

Bezüglich der Charakterisierung der PVX-Replikase sollten zunächst die Bereiche bzw. funktionellen Domänen innerhalb des Replikase-Gens identifiziert werden, welche für die 
virale Replikation verantwortlich gemacht werden können. Zu diesem Zweck wurde auf das System der ,pentapeptide scanning mutagenesis“ (PSM) zurückgegriffen, um eine Insertions-Bibliothek innerhalb des Replikase-Gens $\mathrm{zu}$ erzeugen. Die erzeugten Insertionsmutanten sollten anschießend auf ihre Fähigkeit hin zu replizieren mit Hilfe eines in vivo Agro-Expressionssystems untersucht werden und final zu einer Kartierung des Replikase-Gens beitragen, um anschließend die replikationsaktiven von den später zu untersuchenden rekombinationsaktiven Domänen differenzieren $\mathrm{zu}$ können. Weiterhin sollte ein Sequenzalignment auf Aminosäureebene von 16 Spezies der Potexviren Aufschluss darüber geben, ob die bisher in silico analysierten strukturellen Domänen der Replikase aller Potexviren bezogen auf PVX in konservierten Bereichen vorlagen und in welchen Regionen die erzeugten PS-Mutanten zu finden waren.

Weiterhin sollte die PVX-Replikase auf ihre Beteiligung an der RNA-Rekombination näher charakterisiert werden, um unter anderem funktionelle Bereiche aufdecken zu können, die für die Rekombination verantwortlich gemacht werden können, die bis dato nicht untersucht wurden. Zu diesem Zweck sollte der Rekombinationsnachweis mit einem experimentellen in vivo Agro-Rekombinationssystem unter Ausübung von starkem Selektionsdruck etabliert werden, um die Parameter und Mechanismen der RNARekombination der PVX-Replikase detailliert charakterisieren zu können.

Die erzielten Ergebnisse aus beiden Teilen der Arbeit sollten ein verbessertes Verständnis der Replikation sowie Rekombination von Potexviren ermöglichen.

Die methodischen Durchführungen sowie der Ergebnisteil dieser Arbeit werden im Einzelnen in zwei unabhängig voneinander zu veröffentlichenden Manuskripten (Kapitel 2 und 3) erläutert. In Kapitel 4 werden weitere Methoden und daraus resultierende Ergebnisse, die für eine noch anstehende Veröffentlichung durchgeführt wurden, vorgestellt. Abschließend werden in Kapitel 5 die Ergebnisse der gesamten durchgeführten Arbeit im Detail diskutiert. 


\section{LITERATUR}

Aaziz, R. \& Tepfer, M. (1999a). Recombination in RNA viruses and in virus resistant transgenic plants. J. Gen. Virol. 80: 1339-1346.

Aaziz, R. \& Tepfer, M. (1999b). Recombination between genomic RNAs of two cucumoviruses under conditions of minimal selection pressure. Virology 263: 282-289.

Adair, T.L. \& Kearney, C.M. (2000). Recombination between a 3-kilobase tobacco mosaic virus transgene and a homologous viral construct in the restoration of viral and nonviral genes. Arch. Virol. 145: 1867-1883.

Adams, M.J., Antoniw, J.F., Bar-Joseph, M., Brunt, A.A., Candresse, T., Foster, G.D., Martelli, G.P., Milne, R.G. \& Fauquet, C.M. (2004). The new plant virus family Flexiviridae and assessment of molecular criteria for species demarcation. Arch. Virol. 149: 1045-1060.

Agol, V.I. (1997). Recombination and other genomic rearrangements in picornaviruses. Semin. Virol. 8: 77-84.

Ahlquist, P. (2002). RNA-dependent RNA polymerases, viruses, and RNA silencing. Science 296: 1270-1273.

Ahlquist, P., Noueiry, A., Lee, W.M., Kushner, D.B. \& Dye, B.T. (2003). Host factors in positive-strand RNA virus genome replication. J. Virol. 77: 8181-8186.

Alejska, M., Kurzynska-Kokornika, A., Broda, M., Kierzek, R. \& Figlerowicz, M. (2001). How RNA viruses exchange their genetic material. Acta Biochimica Polonica 48(2): 391-407.

Alejska, M., Figlerowicz, M., Malinowska, N., Urbanowicz, A., \& Figlerowicz, M. (2005). A universal BMV-based RNA recombination system-how to search for general rules in RNA recombination. Nucleic Acids Res. 33: 1-14. 
Allison, R.F., Schneider, W.L. \& Greene, A.E. (1996). Recombination in plants expressing viral transgenes. Semin. Virol. 7: 417-422.

Aranda, M.A., Fraile, A., Dopazo, J., Malpica, J.M. \& Garcia-Arenal, F. (1997). Contribution of mutation and RNA recombination to the evolution of a plant pathogenic RNA. J. Molecular Evol. 44: 81-88.

Arnold, J.J. \& Cameron, C.E. (1999). Poliovirus RNA-dependent RNA polymerase (3Dpol) is sufficient for template switching in vitro. J. Biol. Chem. 274: 2706-2716.

Bancroft, J.B., Rouleau, M., Johnston, R., Prins, L. \& Mackie, G.A. (1991). The entire nucleotide sequence of foxtail mosaic virus RNA. J. Gen. Virol. 72: 2173-2181.

Banner, L.R., Keck, J.G. \& Lai, M.M.C. (1990). A clustering of RNA recombination sites adjacent to hyper-variable region of the peplomer gene of murine coronavirus. J. Virol. 175: 548-555.

Batten, J.S., Yoshinari, S. \& Hemenway, C. (2003). Potato virus X: a model system for virus replication, movement and gene expression. Mol Plant Pathol 4: 125-131.

Beck, D.L., Guilford, P.J., Voot, D.M., Andersen, M.T. \& Forster, R.L.S. (1991). Triple gene block proteins of white clover mosaic potexvirus are required for transport. Virology 183: 695-702.

Bercks, R. (1970). C.M.I./ A.A.B. descriptions of plant viruses, no. 111. Potato virus $X$. Kew, United Kingdom: Commonwealth.

Biebricher, C. \& Gardiner, W.C. (1997). Molecular evolution of RNA in vitro. Biophys. Chem. 66: 179-192.

Bode, J. \& Klinkowski, M. (1968). Einführung in die allgemeinen Probleme. In: Pflanzliche Virologie, Vol. II, part 1: 457 pp., edited by M. Klinkowski, Berlin: Akademie-Verlag. p.161. 
Brandes, J. (1964). Identifizierung von gestreckten pflanzenpathogenen Viren auf morphologischer Grundlage. Mitt. Biol. Bundesanstalt. Land-Forstwirtschaft (Heft 110): 5-130.

Brown, D. \& Gold, L. (1996). RNA replication by Qß replicase: a working model. Proc Natl Acad Sci USA 93: 11558-11562.

Buck, K.W. (1996). Comparison of the replication of positive-stranded RNA viruses of plants and animals. Adv. Virus. Res. 47: 159-251.

Bujarski, J.J. \& Kaesberg, P. (1986). Genetic recombination between RNA components of a multipartite plant virus. Nature 321: 528-531.

Bujarski J.J. (1999). Recombination of viruses. In: A. Granoff, and R.G. Webster (eds.) Enzyclopedia of Virology: 1446-1454. Academic Press, San Diego.

Campbell, R.N. (1979). Fungal vectors of plant viruses. In: Fungal Viruses. XII ${ }^{\text {th }}$ Int. Congr. Microbiol., Mycol. Sect., Munich. 1978. Molitoris, H.P., M. \& Wood, H.A. (Hg.): 8-24. Springer-Verlag, Berlin.

Canto, T., Choi, S.K. \& Palukaitis, P. (2001). A subpopulation of RNA 1 of cucumber mosaic virus contains 3' termini originating from RNAs 2 or 3. J. Gen. Virol. 82: 941-945.

Cascone, P.J., Carpenter, C.D., Li, X.H. \& Simon, A.E. (1990). Recombination between satellite RNAs of turnip crinkle virus. EMBO J. 9: 1709-1715.

Cascone, P.J., Haydar, T.F. \& Simon, A.E. (1993). Sequences and structures required for recombination between virus-associated RNAs. Science 260: 801-805.

Cervera, M.T., Riechmann, J.L., Martin, M.T. \& Garcia, J.A. (1993). 3'-terminal sequences of Plum pox virus PS and o6 isolates: Evidence for RNA recombination within the potyvirus group. Journal of General Virology 74: 329-334. 
Chapman, S., Kavanagh, T. \& Baulcombe, D.C. (1992). Potato virus $X$ as a vector for gene expression in plants. The Plant Journal 2: 549-557.

Chare, E.R., Gould, E.A. \& Holmes, E.C. (2003). Phylogenetic analysis reveals a low rate of homologous recombination in negative-sense RNA viruses. J. Gen. Virol. 84: 26912703.

Chare, E.R. \& Holmes, E.C. (2006). A phylogenetic survey of recombination frequency in plant RNA viruses. Arch. Virol. 151: 933-946.

Chen, Y.K., Derks, A.F., Langeveld, S., Goldbach, R. \& Prins, M. (2001). High sequence conservation among Cucumber mosaic virus isolates from lily. Arch. Virol. 146: 1631-1636.

Cheng, C.P. \& Tsai, C.H. (1999). Structural and functional analysis of the 3' untranslated region of bamboo mosaic potexvirus genomic RNA. J. Mol. Biol. 288: 555-565.

Cheng, J.H., Peng, C.W., Hsu, Y.H. \& Tsai, C.H. (2002). The synthesis of minus-strand RNA of bamboo mosaic potexvirus initiates from multiple sites within the poly(A) tail. J. Virol. 76: 6114-6120.

Cheng, C.P. \& Nagy, P.D. (2003). Mechanism of RNA Recombination in Carmo- and Tombusviruses: Evidence for Template Switching by the RNA-Dependent RNA Polymerase In Vitro. J. Virol. 77 (22): 12033-12047.

Chetverin, A.B., Chetverina, H.V., Demidenko, A.A. \& Ugarov, V.I. (1997). Nonhomologous RNA recombination in a cell-free system: Evidence for a transesterification mechanism guided by secondary structure. Cell 88: 503-513.

Chetverin, A.B. (1999). A new look on RNA recombination. Mol. Biol. 33: 985-996.

Chetverina, H.V., Demidenko, A.A., Ugarov, V.I. \& Chetverin; A.B. (1999). Spontaneous rearrangements in RNA sequences. FEBS Lett. 450: 89-94. 
Cooper, P.D. (1977). Genetics of picornaviruses. Comp. Virol. 9: 133-207.

Darwin, C. (1988). The Origin of Species by Means of Natural Selection, or the Preservation of Favoured Races in the Struggle of Life (Sixth Edition). The Works of Charles Darwin, Vol. 16. New York: New York University Press. (Sigle: OS).

De Graaff, M. \& Jaspars, E.M.J. (1994). Pant viral RNA synthesis in cell-free systems. Annu. Rev. Phytopathol. 32: 311-335.

Desselberger, U., Nakajima, K., Alfino, P., Pedersen, F.S., Haseltine, W.A., Hannoun, C. \& Palese, P. (1978). Biochemical evidence that "new" influenza virus strains in nature may arise by recombination (reassortment). Proc. Natl. Acad. Sci. USA 75, 3341-3345.

Dolja, R. \& Carrington, J. C. (1992). Evolution of positive-strand RNA viruses. Semin. Virol. 3: 315-326.

Domingo, E, Martínez-Salas E, Sobrino F. et al. (1985). The quasispecies (extremely heterogeneous) nature of viral RNA genome populations: biological relevance--a review. Gene 40(1): 1-8.

Domingo, E., Holland, J.J. \& Ahlquist, P. (1988). RNA genetics, vol. 1-3. CRC Press, Boca Raton, Fla.

Domingo, E. \& Holland, J. (1994). Mutations and rapid evolution of RNA viruses (ed. S., M. S.) Raven Press, New York.

Domingo, E. \& Holland, J.J. (1997). RNA virus mutations and fitness for survival. Annu. Rev. Microbiol. 51: 151-78.

Domingo, E., Escarmis, C., Menéndez-Arias, L. \& Holland, J.J. (1999). Viral quasispecies and fitness variations. In: Origin and Evolution of Viruses. Eds. Domingo E., Webster R.G., Holland J.J. San Diego: Academic. 141-161. 
Domingo, E., Baranowski, E., Escarmis, C. ,Sobrino, F. \& Holland, J.J. (2002). Error frequencies of picornavirus RNA polymerases: evolutionary implications for virus populations. In: Molecular biology of picornaviruses. Eds. Semler B.L., Wimmer E. Washington: ASM: 285-298.

Doronin, S.V. \& Hemenway, C. (1996). Synthesis of potato virus X RNAs by membranecontaining extracts. J. Virol. 70: 4795-4799.

Drake, J.W. (1993). Rates of spontaneous mutation among RNA viruses. Proc. Natl. Acad. Sci. USA 90: 4171-4175.

Drake, J.W. \& Holland, J.J. (1999). Mutation rates among RNA viruses. Proc. Natl. Acad. Sci. USA 96: 13910-13913.

Dreher, T.W. (1999). Functions of the $3 \not$-untranslated regions of positive strand RNA viral genomes. Annu. Rev. Phytopathol. 37: 151-174.

Drugeon, G., Urcuqui-Inchima, S., Milner, M., Kadaré, G., Valle, R.P.C., Voyatzakis, A., Haenni, A.-L. \& Schirawski, J. (1999). The strategies of plant virus gene expression: Models of economy. Plant Sci. 148:77-88.

Edwards, M.C., Petty, I.T.D. \& Jackson, A.O. (1992). RNA recombination in the genome of Barley stripe mosaic virus. Virology 189: 389-392.

Eigen, M. (1971). Molekulare Selbstorganisation und Evolution (Self organization of matter and the evolution of biological macro molecules.), Naturwissenschaften Bd. 58(10): 465-523.

Eigen, M. \& Schuster, P. (1979). The hypercycle. A principle of natural self-organization. Springer-Verlag, Berlin.

Eigen, M., McCaskill, J. \& Schuster, P. (1989). The molecular quasispecies. Adv. Chem. Phys. 75: 149-263. 
Elleuch, A., Fakhfakh, H., Pelchat, M., Landry, P., Marrakchi, M. \& Perreault, J.-P. (2002). Sequencing of Australian grapevine viroid and yellow speckle viroid isolated from Tunisian grapevine without passage in an indicator plant. European Journal of Plant Pathology 108: 815-820.

Figlerowicz, M., Nagy, P.D., \& Bujarski, J.J. (1997). A mutation in the putative RNA polymerase gene inhibits nonhomologous, but not homologous, genetic recombination in an RNA virus. Proceedings of the National Academy of Sciences, USA 94: 2073-2078.

Figlerowicz, M., \& Bujarski, J.J. (1998). RNA recombination in brome mosaic virus, a model plus stranded RNA virus. Acta Biochim. Polon.45: 1-23.

Figlerowicz, M., Nagy, P.D., Tang, N., Kao, C.C. \& Bujarski, J.J. (1998). Mutations in the $\mathrm{N}$ terminus of the brome mosaic virus polymerase affect genetic RNA-RNA recombination. J. Virol. 72: 9192-9200.

Figlerowicz, M. (2000). Role of RNA structure in non-homologous recombination between genomic molecules of brome mosaic virus. Nucleic Acids Res. 28: 1714-1723.

Finke, S. \& Conzelmann, K.K. (1997). Ambisense gene expression from recombinant rabies virus: random packaging of positive- and negative-strand ribonucleoprotein complexes into rabies virions. J. Virol. October; 71(10): 7281-7288.

Fraile, A., Alonso-Prados, J.L., Aranda, M.A., Bernal, J.J., Malpica, J.M. \& GarciaArenal, F., (1997). Genetic exchange by recombination or reassortment is infrequent in natural populations of a tripartite RNA plant virus. J.Virol. 71: 934-940.

Fu, K., \& Baric, R.S. (1992). Evidence for variable rates of recombination in the MHV genome. Virology, 189: 88-102.

Gal, S., Pisan, B., Hohn, T., Grimsley, N. \& Hohn, B. (1992). Agroinfection of transgenic plants leads to viable cauliflower mosaic virus by intermolecular recombination. Virology 187: 525-533. 
Gal-On, A., Meiri, E., Raccah, B. \& Gaba, V. (1998). Recombination of engineered defective RNA species produces infective potyvirus in planta. J. Virol. 72: 5268-5270.

García-Arenal, F., Fraile, A. \& Malpica, J.M. (2001). Variability and genetic structure of plant virus populations. Annu Rev Phytopathol 39:157-186.

García-Arenal, F., Fraile, A. \& Malpica, J.M. (2003). Variation and evolution of plant virus populations. Int. Microbiol. 6: 225-232.

Gibbs, M.J. \& Cooper, J.I. (1995). A recombinational event in the history of luteoviruses probably induced by baise-pairing between the genomes of two distinct viruses. Virology 206: $1129-1132$.

Gilmer, D., Bouzoubaa, S., Hehn, A., Guilley, H., Richards, K. \& Jonard, G. (1992). Efficient cell-to-cell movement of Beet necrotic yellow vein virus requires 3 Vproximal genes located on RNA 2. Virology 189: 40-47.

Glais, L., Tribodet, M. \& Kerlan, C. (2002). Genomic variability in Potato potyvirus $Y$ (PVY): evidence that PVYNW and PVYNTN variants are single to multiple recombinants between PVYO and PVYN isolates. Arch. Virol. 147: 363-378.

Glasa, M., Marie-Jeanne, V., Moury, B., Kúdela, O. \& Quiot, J.B. (2002). Molecular variability of the P3-6K1 genomic region among geographically and biologically distinct isolates of Plum pox virus. Arch. Virol. 147: 563-575.

Gmyl, A.P., Belousov, E.V., Maslova, S.V., Khitrina, E.V., Chetverin, A.B. \& Agol, V.I. (1999). Nonreplicative RNA recombination in poliovirus. J. Virol. 73: 8958-8965.

Gmyl, A.P., Korshenko, S.A., Belousov, E.V., Khitrina, E.V. \& Agol, V.I. (2003). Nonreplicative homologous RNA recombination: Promiscuous joining of RNA pieces. RNA 9: 1221-1231.

Gmyl, A.P. \& Agol, V.I. (2005). Diverse mechanisms of RNA recombination. Molecular Biology 39(4): 529-542. 
Gorbalenya, A.E. \& Koonin, E.V. (1989). Viral proteins containing the purine NTPbinding sequence pattern. Nucleic Acids Research 17: 8413-8440.

Gorbalenya, A.E, Koonin, E.V., Donchenko, A.P. \& Blinov, V.M. (1989). Two related superfamilies of putative helicases involved in replication, recombination, repair and expression of DNA and RNA genomes. Nucleic Acids Res 17: 4713-4730.

Gorbalenya A.E., Koonin, E.V., \& Wolf, Y.I. (1990). A new superfamily of putative NTPbinding domains encoded by genomes of small DNA and RNA viruses. FEBS Lett 262: $145-148$.

Gorbalenya AE \& Koonin E.V. (1993). Helicases: amino acid sequence comparison and structurefunction relationships. Curr. Opin. Struct. Biol., 3: 419-429.

Habili, N. \& Francki, R.I. (1974). Comparative studies on Tomato aspermy and Cucumber mosaic viruses. III. Further studies on relationship and construction of a virus from parts of the two viral genomes. Virology 61: 443-449.

Hall, M.C. \& Matson, S.W. (1999). Helicase motifs: the engine that powers DNA unwinding. Mol.Microbiol., 34: 867-877.

Hansen, J.L., Long, A.M. \& Schultz, S.C. (1997). Structure of the RNA-dependent RNA polymerase of Poliovirus. Structure 5:1109-1122.

Hemenway, C.L. \& Lommel, S.A. (2000). Manipulating plant viral RNA transcription signals. Genet. Eng. 22: 171-195.

Herzog, E., Hemmer, O., Hauser, S., Meyer, G., Bouzoubaa, S. \& Fritsch, C. (1998). Identification of genes involved in replication and movement of peanut clump virus. Virology 248: 312-322.

Hoffmann, G.M. \& Schmutterer, H. (1999). Parasitäre Krankheiten und Schädlinge an landwirtschaftlichen Kulturpflanzen. 2. Auflage: Eugen Ulmer Verlag, Stuttgart, Germany. 
Holland, J.J. (ed.). (1992). Genetic diversity of RNA viruses. Vol. 176: Springer-Verlag, Berlin, Germany.

Holland, J.J. \& Domingo, E. (1998). Origin and evolution of viruses. Virus Genes 16: 13-21.

Hou, Y.U., \& Gilbertson, R.L. (1996). Increased Pathogenicity in a Pseudorecombinant Bipartite Geminivirus Correlates with Intermolecular Recombination. J. Virol. 70(8): $5430-5436$.

Huang, Y.L., Han, Y.T., Chang, Y.T., Hsu, Y.H. \& Meng, M. (2004). Critical residues for GTP methylation and formation of the covalent m7GMP-enzyme intermediate in the capping enzyme domain of bamboo mosaic virus. J Virol 78: 1271-1280.

Huisman, M.J., Linthorst, H.J.M., Bol, J.F. \& Cornelissen, B.J.C. (1988). The complete nucleotide sequence of Potato virus $X$ and its homologies at the amino acid level with various plus-stranded RNA viruses. J Gen Virol 69: 1789-1798.

Huisman, M.J., Cornelissen, B.J.C., Groenendijk, C.F.M., Bol, J.F. \& van VlotenDoting, L. (1989). Alfalfa mosaic virus temperature-sensitive mutants. V. The nucleotide sequence of TBS 7 RNA 3 shows limited nucleotide changes and evidence for heterologous recombination. Virology 171: 409-416.

Hull, R. (2002). Matthew’s Plant Virology. 4th edn. Academic Press San Diego.

Ilyina, T.V., Gorbalenya, A.E. \& Koonin, E.V. (1992). Organization and evolution of bacterial and bacteriophage primase-helicase systems. J. Mol. Evol., 34: 351-357.

Jarvis, T.C. \& Kirkegaard, K. (1992). Poliovirus RNA recombination: mechanistic studies in the absence of selection. EMBO J. 11: 3135-3145.

Kadaré; G, \& Haenni, A.L. (1997) Virus encoded RNA helicases. J Virol 71: 2583-2590. 
Kääriäinen, L., \& Ahola, T. (2002). Functions of alphavirus nonstructural proteins in RNA replication. Prog. Nucleic. Acid. Res. Mol. Biol. 71: 187-222.

Kalinina, N.O., Rakitina, D.V., Solovyev, A.G., Schiemann, J. \& Morozov, S.Y. (2002). RNA helicase activity of the plant virus movement proteins encoded by the first gene of the triple gene block. Virology, 296: 321-329.

Kao, C.C., Singh, P. \& Ecker, D.J. (2001). De novo initiation of viral RNA-dependent RNA synthesis. Virology 287: 251-260.

Keck, J.G., Makino, S., Soe, L.H., Fleming, J.O., Stohlman, S.A. \& Lai, M.M. (1987). RNA recombination of coronavirus. Adv. Exp. Med. Biol. 218: 99-107.

Khatchikian, D., Orlich, M. \& Rott, R. (1989). Increased viral pathogenicity after insertion of a $28 \mathrm{~S}$ ribosomal RNA sequence into the haemagglutinin gene of an influenza virus. Nature 340: 156-157.

Kim, K.H. \& Hemenway, C. (1996). The 5' nontranslated region of potato virus X RNA affects both genomic and subgenomic RNA synthesis. J. Virol. 70: 5533-5540.

Kim, K.H. \& Hemenway, C. (1997) Mutations that alter a conserved element upstream of the potato virus $X$ triple block and coat protein genes affect subgenomic RNA accumulation. Virology 232: 187-197.

Kim, K.H. \& Hemenway, C.L. (1999). Long-distance RNA-RNA interactions and conserved sequence elements affect potato virus X plus-strand RNA accumulation. RNA 5: 636-645.

Kim, M. J. \& Kao, C. (2001). Factors regulating template switch in vitro by viral RNA-dependent RNA polymerases: implications for RNA-RNA recombination. Proc. Natl. Acad. Sci. USA 98: 4972-4977. 
Kim, K.H., Kwon, S.J. \& Hemenway, C. (2002). Cellular protein binds to sequences near the 5 ' terminus of potato virus X RNA that are important for virus replication. Virology 301(2): 305-312.

King, A.M.Q., McCahon, D., Slade, W.R. \& Newman, J.W.I. (1982). Recombination in RNA. Cell. 29: 921-928.

King, A.M.Q., Ortlepp, S.A., Newman, J.W.I. \& McCahon, D. (1987). Genetic recombination in RNA viruses. In The Molecular Biology of the positive Stranded RNA Viruses, pp. 129-152. Edited by D. J. Rowlands, M. A. Mayo \& B. W. J. Mahy. London: Academic Press.

Kirkegaard, K. \& Baltimore, D. (1986). The mechanism of RNA recombination in poliovirus. Cell 47: 433-443.

Koenig, R. \& Lesemann, D.-E. (1989). Potato virus X. CMI/AAB. Description of plant viruses, No. 354.

Koonin, E.V. (1991) The phylogeny of RNA-dependent RNA polymerases of positivestrand RNA viruses. J. Gen. Virol. 72: 2197-2206.

Koonin, E.V. (1993). Computer-assisted identification of a putative methyltransferase domain in NS5 protein of flaviviruses and 2 protein of reovirus. J. Gen. Virol. 74: 733740.

Koonin, E.V. \& Dolja, V.V. (1993) Evolution and taxonomy of positive-strand RNA viruses: implications of comparative analysis of amino acid sequences. Crit. Rev. Biochem. Mol. Biol. 28: 375-430.

Kwon, S.J., Park, M.R., Kim, K.W., Plante, C.A., Hemenway, C.L. \& Kim, K. H. (2005). cis-Acting sequences required for coat protein binding and in vitro assembly of Potato virus X. Virology 334: 83-97. 
Kwon, S.J. \& Kim, K.H. (2006). The SL1 stem-loop structure at the 5'-end of potato virus $\mathrm{X}$ RNA is required for efficient binding to host proteins and for viral infectivity. Mol. Cells 21: 63-75.

Lai, M.M.C. (1992). RNA recombination in animal and plant viruses. Microbiological Reviews 56: 61-79.

Lai, M.M.C. (1998). Cellular factors in the transcription and replication of viral RNA genomes: A parallel to DNA-dependent RNA transcription. Virology 244: 1-12.

Ledinko, N. (1963). Genetic recombination with poliovirus type 1. Studies of crosses between a normal horse serum-resistant mutant and several guanidine-resistant mutants of the same strain. Virology 20: 107-119.

Le Gall, O., Lanneau, M., Candresse, T. \& Dunez, J. (1995). The nucleotide sequence of the RNA-2 of an isolate of the english serotype of Tomato black ring virus: RNA recombination in the history of nepoviruses. J. Gen. Virol. 76: 1279-1283.

Leshchiner, A.D., Solovyev, A.G., Morozov, S.Y. \& Kalinina, N.O. (2006). A minimal region in the NTPase/helicase domain of the TGBp1 plant virus movement protein is responsible for ATPase activity and cooperative RNA binding. J. Gen. Virol. 87: 30873095 .

Lewis, S.E. (1999). Life cycle of the mammalian germ cell: implication for spontaneous mutation frequencies. Teratology 59: 205-209.

Li, Y.I., Chen, Y.J., Hsu, Y.H. \& Meng, M. (2001a). Characterization of the AdoMetdependent guanylyltransferase activity that is associated with the $\mathrm{N}$ terminus of bamboo mosaic virus replicase. J. Virol. 75: 782-788.

Li, Y.I., Shih, T.W., Hsu, Y.H., Han, Y.T., Huang, Y.L. \& Meng, M. (2001b). The helicase-like domain of plant potexvirus replicase participates in formation of RNA 5' cap structure by exhibiting RNA 5'-triphosphatase activity. J. Virol. 75: 12114-12120. 
Lin, J.W., Chiu, H.N., Chen, I.H., Chen, T.C., Hsu, Y.H., Tsai, C.H. (2005). Structural and functional analysis of the cis-acting elements required for plus-strand RNA synthesis of Bamboo mosaic virus. J. Virol. 79: 9046-9053.

Lommel, S.A. \& Xiong, Z. (1991). Reconstitution of a functional Red clover necrotic mosaic virus by recombinational rescue of the cell-to-cell movement gene expressed in transgenic plants. Journal of Cellular Biochemistry 15A: 151.

Longstaff, M., Brigneti, G., Boccard, F., Chapman, S. \& Baulcombe, D.C. (1993). Extreme resistance to potato virus $\mathrm{X}$ infection in plants expressing a modified component of the putative viral replicase. EMBO J. 12: 379-386.

MacFarlane, S.A., (1997). Natural recombination among plant virus genomes: Evidence from tobraviruses. Seminars in Virology 8: 25-31.

Makino, S., Keck, J.G., StohIman, S.A. \& Lai, M.M. (1986). High-frequency RNA recombination of murine coronaviruses. J. Virol. 57: 729-737.

Masuta, C., Nishimura, M., Morishita, H. \& Hataya, T. (1998). A single amino acid change in viral genome associated protein of potato virus $\mathrm{Y}$ correlates with resistance breaking in Vrigin a mutant tobacco. Phytopathology 89: 118-123.

Masuta, C. (2002). Recombination in plant RNA viruses. In Khan J, Dijkstra J (eds.), In Plant viruses as molecular pathogens (pp. 202-223). Binghamton, NY: The Harworth Press, Inc.

Meyers, G. \& Thiel, H.-J. (1996). Molecular characterization of pestiviruses. Adv. Virus Res. 47: 53-118.

Miller, J.T., Ge, Z., Morris, S., Das, D., Leis, J. (1997). Multiple biological roles associated with the rous sarcoma virus 5' untranslated RNA U5-IR stem and loop. J. Virol. 71: 7648-7656. 
Miller, E.D., Plante, C.A., Kim, K.H., Brown, J.W. \& Hemenway, C. (1998) Stem-loop structure in the $5 \notin$ region of potato virus $\mathrm{X}$ genome required for plus-strand RNA accumulation. J. Mol. Biol. 284: 591-608.

Miller, E.D., Kim, K.H. \& Hemenway, C. (1999) Restoration of a stemloop structure required for potato virus $\mathrm{X}$ accumulation indicates selection for a mismatch and a GNRA tetraloop. Virology 260: 342-353.

Moreira, A., Jones, R.A.C. \& Fribourg, C.E. (1980). Properties of a resistance-breaking strain of potato virus X. Ann. Appl. Biol. 95: 93-103.

Moreno, I.M., Malpica, J.M., Diaz-Pendon, J.A., Moriones, E., Fraile, A \& GarciaArenal, R. (2004). Variability and genetic structure of the population of Watermelon mosaic virus infecting melon in Spain. Virology 318: 451-60.

Morozov, S.Y., Gorbulev, V.G., Novikov, V.K., Agranovskii, A.A., Kozlov, Y.V., Atabekov, I.G. \& Baev, A.A. (1981). The primary structure of 5'-and 3'terminal regions of potato virus X genomic RNA. Proc. Acak. Nauk. SSSR 259: 723-725.

Morozov, S., Miroshnichenko, N.A., Solovyev, A.G., Fedorkin, O.N., Zelenina, D.A., Lukasheva, L.I., Karasev, A.V., Dolja, V.V. \& Atabekov, J.G. (1991) Expression strategy of the potato virus X triple gene block. J. Gen. Virol. 72: 2039-2042.

Morozov, S.Y., Solovyev, A.G., Kalinina, N.O., Fedorkin, O.N., Samuilova, O.V., Schiemann, J. \& Atabekov, J.G. (1999). Evidence for two nonoverlapping functional domains in the potato virus X 25K movement protein. Virology 260: 55-63.

Morozov, S. \& Solovyev, A. (1999). Genome organization in RNA viruses. In Molecular Biology of Plant Viruses. Seite 47-98. Editiert von C.L. Mandahar. Dordrecht: Kluwer.

Morse, S.S. (1994). The viruses of the future? Emerging viruses and evolution. In The Evolutionary Biology of Viruses, ed. S.S. Morse, pp. 325-335. New York: Raven. 
Munishkin, A.V., Voronin, L.A. \& Chetverin, A.B. (1988). An in vivo recombinant RNA capable of autocatalytic synthesis by Q beta replicase. Nature 333: 473-475.

Nagy, P.D. \& Bujarski, J.J. (1995). Efficient system for homologous RNA recombination in brome mosaic virus: Sequence and structure requirements and accuracy of crossovers. J. Virol. 69: 131-140.

Nagy, P.D. \& Bujarski, J.J. (1996). Homologous RNA recombination in Brome mosaic virus: AU-rich sequences decrease the accuracy of crossovers. Journal of Virology 70: 415-426.

Nagy, P.D. \& J.J. Bujarski. (1997). Engineering of homologous recombination hotspots with AU-rich sequences in brome mosaic virus. J. Virol. 71: 3799-3810.

Nagy, P.D. \& Simon, A.E. (1997). New insights into the mechanisms of RNA recombination. Virology 235: 1-9.

Nagy, P.D., Zhang, C. \& Simon, A.E. (1998). Dissecting RNA recombination in vitro: role of RNA sequences and the viral replicase. EMBO J. 17: 2392- 2403.

Nagy, P.D., Pogany, J. \& Simon, A.E. (1999). RNA elements required for RNA recombination function as replication enhancers in vitro and in vivo in a plus-strand RNA virus. EMBO J. 18(20): 5653-65.

Nienhaus, F. \& Stille, B. (1965). Übertragung des Kartoffel X Virus durch Zoosporen von Synchytrium endobioticum. Phytopath. Z. 54: 335.

Oparka, K.J., Roberts, A.G., Roberts, I.M., Prior, D.A.M. \& Santa Cruz, S. (1996). Viral coat protein is targeted to, but does not gate plasmodesmata during cell-to-cell movement of Potato virus X. Plant J. 10: 805-813.

Orman, B.E., Celnik, R.M., Mandel, A.M., Torres, H.N \& Mentaberry, A.N. (1990). Complete cDNA sequence of a South American isolate of potato virus X. Virus Research 16(3): 293-305. 
Osman, T.A.M. \& Buck, K.W. (1997). The tobacco mosaic virus RNA polymerase complex contains a plant protein related to the RNA-binding subunit of yeast eIF-3. J. Virol. 71: 6075-6082.

Palukaitis, P. \& Roossnick, M.J. (1995). Variation in the hypervariable region of cucumber mosaic virus satellite RNAs is affected by the helper virus and the initial sequence context. Virology 206: 765-768.

Panavas, T. \& Nagy, P.D. (2003). Yeast as a model host to study replication and recombination of defective interfering RNA of tomato bushy stunt virus. Virology 314: $315-325$.

Petty, I.T.D. \& Jackson, A.O. (1990). Mutational analysis of barley stripe mosaic virus RNAb. Virology 179: 712-718.

Pillai-Nair, N., Kim, K.H. \& Hemenway, C. (2003). cis-Acting regulatory elements in the potato virus X $3^{\prime}$ non-translated region differentially affect minus-strand and plusstrand RNA accumulation. J. Mol. Biol. 326: 701-720.

Quadt, R., Kao, C.C., Browning, K.S., Hershberger, R.P. \& Ahlquist, P. (1993). Characterization of a host protein associated with brome mosaic virus RNA-dependent RNA-polymerase. Proc. Natl. Acad. Sci. USA 90: 1498-1502.

Qui, W.P., Geske, S.M, Hickey, C.M. \& Moyer, J.W. (1998). Tomato spotted wilt tospovirus genome reassortment and genome segment specific adaptation. Virology 244: 186-194.

Raju, R., Subramaniam, S.V. \& Hajjou, M. (1995). Genesis of Sindbis virus by in vivo recombination of nonreplicative precursors. J. Virol. 69: 7391-7401.

Revers, F., Le Gall, O., Candresse, T., Le Romancer, M. \& Dunez, J., (1996). Frequent occurrence of recombinant potyvirus isolates. J. Gen. Virol. 77: 1953-1965. 
Rezaian, M.A. (1990). Australian grapevine viroid--evidence for extensive recombination between viroids. Nucleic Acids Res. April 11; 18(7): 1813-1818.

Robinson, D.J., Hamilton, W.D.O., Harrison, B.D. \& Baulcombe, D.C. (1987). Two anomalous tobravirus isolates: Evidence for RNA recombination in nature. Journal of General Virology 68: 2551-2561.

Roossinck, M.J., Sleat, D. \& Palukaitis, P. (1992). Satellite RNAs of plant viruses: structures and biological effects. Microbiol. Rev. 56: 265-279.

Roossinck, M.J. (1997). Mechanisms of plant virus evolution. Annual Review of Phytopathology 35: 191-209.

Rott, M.E., Tremaine, J.H. \& Rochon, D.M. (1991). Comparision of the 5' and 3'termini of Tomato ringspot virus RNA1 and RNA2: Evidence for RNA recombination. Virology 185: 468-472.

Rozanov, M.N., Koonin, E.V., Gorbalenya, A.E. (1992). Conservation of the putative methyltransferase domain: A hallmark of the "Sindbislike" supergroup of positive-strand RNA viruses. J. Gen. Virol. 73: 2129-2134.

Salanki, K., Carrére, I., Jaquemond, M., Balázs, E. \& Tepfer, M., (1997). Biological properties of pseudorecombinant and recombinant strains created with Cucumber mosaic virus and Tomato aspermy virus. J. Virol. 71: 3597-3602.

Santa Cruz, S., Roberts, A.G., Prior, D.A.M., Chapman, S. \& Oparka, K.J. (1998). Cell-to-cell and phloem-mediated transport of potato virus X: The role of the virions. Plant Cell 10: 495-510.

Schmutterer, H. (1960). Zur Kenntnis der Beißinsekten als Überträger pflanzlicher Viren (Teil I und II). Z.angew. Entomol. 47: 277-301, 416-439.

Schuster, P. (1999). Mendel-Vorlesung: Evolution der Moleküle. Einblicke in die Natur mit Perspektiven für die Biotechnologie. Universität Wien: TBI Preprint No. 99-pks-010. 
Seybert, A., Hegyi, A., Siddell, S.G. \& Ziebuhr, J. (2000a). The human coronavirus 229E superfamily 1 helicase has RNA and DNA duplex-unwinding activities with 5'-to-3' polarity. RNA 6: 1056-1068.

Seybert, A., van Dinten, L.C., Snijder, E.J. \& Ziebuhr, J. (2000b). Biochemical characterization of the equine arteritis virus helicase suggests a close functional relationship between arterivirus and coronavirus helicases. J. Virol. 74: 9586-9593.

Shirako, Y. \& Brakke, M.K. (1984). Spontaneous deletion mutation of Soil-borne wheat mosaic virus RNA II. Journal of General Virology 65: 855-858.

Simon, A.E. \& Bujarski, J.J., (1994). RNA-RNA recombination and evolution in virus infected plants. Annual Review of Phytopathology 32: 337-362.

Simon A.E., Nagy P.D. (1996). RNA recombination in turnip crinkle virus: Its role in formation of chimeric RNAs, multimers, and in 3'-end repair. Semin. Virol. 7: 373-379.

Sit, T.L., Leclerc, D., AbouHaidar, M.G. (1994). The minimal 5' sequence for in vitro initiation of papaya mosaic potexvirus assembly. Virology 199: 238-242.

Skryabin, K.G., Morozov, S.Y., Kraev, A.S., Rozanov, M.N., Chernov, B.K., Lukasheva, L.I. \& Atabekov, J.G. (1988). Conserved and variable elements in RNA genomes of potexviruses. FEBS Letters 240: 33-40.

Smirnyagina, E.V., Morozov, S.Y., Rodionova, N.P., Miroshnichenko, N.A., Solovev, A.G., Fedorkin, O.N. \& Atabekov, J.G. (1991). Translational efficiency and competitive ability of mRNAs with 5'- untranslated alpha beta-leader of potato virus X RNA. Biochimie 73: 587-598.

Smith, K.M. (1931). On the composite nature of certain potato virus diseases of the mosaic group as revealed by the use of plant indicators and selective methods of transmission. Proc. Royal Soc. B. 109: 251-267. 
Smith, I.M., Dunez, J., Phillips, D.H., Lelliott, R.A. \& Archer, S.A. (1988). European Handbook of Plant Diseases. Blackwell Scientific Publications Oxford, London, Edinburgh, Boston, Palo Alto, Melbourne.

Solomon-Blackburn, R.M., \& Barker, H. (2001a). A review of host major-gene resistance to potato virus $\mathrm{X}, \mathrm{Y}, \mathrm{A}$ and $\mathrm{V}$ in potato: genes, genetics and mapped locations. Heredity 86: 8-16.

Solomon-Blackburn, R.M., \& Barker, H. (2001b). Breeding virus resistant potatoes (Solanum tuberosum): a review of traditional and molecular approaches. Heredity 86: 1735.

Sonenberg; N., Shatkin, A.J., Ricciardi, R.P., Rubin, M. \& Goodman, R.M. (1978). Analysis of terminal structures of RNA from potato virus X. Nucleic Acids Research 5(7): 2501-2512.

Spence, N. \& Barbara, D. (2000). Viroids and other sub-viral pathogens of plants: the smallest living fossils. Microbiology Today. Vol. 20: 168-170.

Sriskanda, V.S., Pruss, G., Ge, X. \& Vance, V.B. (1996). An eight-nucleotide sequence in the potato virus X $3^{\prime}$ untranslated region is required for both host protein binding and viral multiplication. J. Virol. 70: 5266-5271.

Steinhauer, D.A., Domingo, E. \& Holland, J.J. (1992). Lack of evidence for proofreading mechanisms associated with an RNA virus polymerase. Gene 122: 281-88.

Strauss, J.H. \& Strauss, E.G. (1994). The alphaviruses: gene expression, replication, and evolution. Microbiol. Rev. 58: 491-562.

Teycheney, P.-Y., Aaziz, R., Dinant, S., Salanki, K., Tourneur, C., Balazs, E., Jacquemond, M. \& Tepfer, M. (2000). Synthesis of (-)-strand RNA from the 3 'untranslated region of plant viral genomes expressed in transgenic plants upon infection with related viruses. J. Gen. Virol. 81: 1121-1126. 
Taylor, D.N. \& Carr, J.P. (2000) The GCD10 subunit of yeast eIF-3 binds the methyltransferase-like domain of the 126 and $183 \mathrm{kDa}$ replicase proteins of tobacco mosaic virus in the yeast two-hybrid system. J Gen Virol 81: 1587-1591.

Van der Heijden, M.W. \& Bol, J.F. (2002). Composition of alphavirus-like replication complexes: involvement of virus and host encoded proteins. Arch. Virol. 147: 875-898.

Van der Kuyl, A.C., Neeleman, L. \& Bol, J.F. (1991). Complementation and recombination between alfalfa mosaic virus RNA3 mutants in tobacco plants. Virology 183: $731-738$.

Varrelmann, M., Palkovics, L. \& Maiss, E. (2000). Transgenic or plant expression vector-mediated recombination of plum pox virus. J. Virol. 74: 7462-7469.

Verchot, J., Angell, S.M. \& Baulcombe, D.C. (1998). In vivo translation of the triple gene block of potato virus X requires to subgenomic mRNAs. J. Virol. 72: 8316-8320.

Verchot-Lubicz, J. (2005). A new model for cell-to-cell movement of potexviruses. Mol. Plant Microbe Interact. 18: 283-290.

Verchot-Lubicz, J., Ye, C.M. \& Bamunusinghe, D. (2007). Molecular biology of potexviruses: recent advances. J. Gen. Virol. 88 (6): 1643-1655.

Walters, H.J. (1952). Some relationships of three plant viruses to the differential seed potato certification. Phytopathology Am. Potato 42: 355-362.

White, K.A., Bancroft, J.B. \& Mackie, G.A. (1992). Mutagenesis of a hexanucleotide sequence conserved in potexvirus RNAs. Virology 189: 817-820.

White, K.A. \& Morris, T.J. (1994). Recombination between defective tombusvirus RNAs generates functional hybrid genomes. Proceedings of the National Academy of Sciences USA 91: 3642-3646. 
White, K.A. \& Morris. T.J. (1995). RNA determinants of junction site selection in RNA virus determinants and defecting interfering RNAs. RNA1: 1029-1040.

White, P.S., Morales, F.J. \& Roossinck, M.J. (1995). Interspecific reassortment in the evolution of a cucumovirus. Virology 207: 334-37.

Whittle, C.-A. \& Johnston, M.O. (2006). Moving forward in determining the causes of mutations: the features of plants that make them suitable for assessing the impact of environmental factors and cell age. Journal of Experimental Botany, Vol. 57, No. 9, pp.: 1847-1855.

Wu, H.Y. \& Brian, D.A. (2007). 5'-Proximal Ho Spot for an Inducible Positive-toNegative-Strand Template Switch by Coranovirus RNA-Dependent RNA Polymerase. J. Virol. 81: 3206-3215.

Zhang, C., Cascone, P.J. \& Simon, A.E. (1991). Recombination between satellite and genomic RNAs of turnip crinkle virus. Virology 184: 791-794. 


\title{
Kapitel 2
}

\section{Functional mapping of PVX RNA-dependent RNA-replicase using pentapeptide scanning mutagenesis - Identification of regions essential for replication and subgenomic RNA amplification*}

\author{
Heidrun-Katharina Draghici ${ }^{\mathrm{a}}$, Ruth Pilot ${ }^{\mathrm{a}}$, Heike Thiel $^{\mathrm{a}}$ and Mark Varrelmann ${ }^{\mathrm{a}, \mathrm{b}}$ \\ ${ }^{a}$ Department of Crop Sciences, Section Plant Virology, University of Göttingen, \\ Grisebachstrasse 6, D-37077 Göttingen, Germany \\ ${ }^{b}$ Institute of Sugar Beet Research, Department of Phytopathology, Holtenser Landstr. 77, \\ D-37079 Göttingen, Germany
}

\begin{abstract}
The replicase protein of Potato virus X (PVX), type species of the genus Potexvirus, was selected to identify regions essential for replication and subgenomic RNA synthesis. Replicase amino acid (aa) sequence alignment of 16 Potexvirus species resulted in the detection of overall sequence homology of 34.4 to $65.4 \%$. Two regions of consensus with a high proportion of conserved aa (1-411 and 617-1437 according to PVX) were separated by a hyper-variable linker region. Pentapeptide scanning (PS) mutagenesis in a PVX fulllength clone expressing green fluorescent protein (GFP) was carried out. For 69 selected PS-mutants where insertions were spread randomly over the replicase ORF the position of the insertion was determined. The replication activity was evaluated by GFP expression from subgenomic viral RNA of PVX replicase mutants. Only one functional PS-mutant was detected in the $\mathrm{N}$-terminal 430 aa, containing the conserved methyltransferase domain of the protein. In the linker region from aa 430-595, nine mutations were discovered which did not induce significant effects on the replicase replication ability. The part of the protein including helicase and polymerase domains was
\end{abstract}

\footnotetext{
${ }^{*}$ This paper is accepted in Virus Research (doi:10.1016/j.virusres.2009.03.013)
} 
highly intolerant for the PS insertion as demonstrated by 24 independent more or less uniformly spread mutants.

Keywords: Alpha-like virus; PVX; Replication; Replicase functional domains; Random mutagenesis

\section{INTRODUCTION}

Potato virus $X$ (PVX), type species of the genus Potexvirus, family Flexiviridae (Adams et al., 2004) belongs to the supergroup III, alpha-like viruses (Koonin, 1991; Koonin and Dolja, 1993) displaying flexuous, rod-shaped particle morphology. Alpha-like viruses possess replicase proteins which differ in structural and functional domains in comparison to picorna-, carmo- and flavi-like viruses (reviewed in Van der Heijden and Bol, 2002). PVX represents a replication model system among the RNA viruses (Batten et al., 2003; Verchot-Lubicz et al., 2007). This includes studies, which have supplied detailed knowledge about the involvement of the 5'-non-coding region in plus-strand RNA synthesis (Kwon \& Kim, 2006; Miller et al., 1999) and cis elements of the 3'-non-coding region, controlling plus-as well as minus-strand synthesis (Cheng \& Tsai, 1999; Cheng et al., 2002; Chiu et al., 2002; Lin et al., 2005; Pillai-Nair et al., 2003). The PVX ORF1 encodes the $166 \mathrm{kDa}$ replicase or RNA-dependent RNA-polymerase ( RdRp) and is the initial translation product from genomic RNA during virus infection. Several lines of evidence have demonstrated that the Potexvirus replicase protein is the only viral protein required for virus RNA synthesis and replication. The protein contains conserved replication associated domains (Koonin and Dolja, 1993) and displays significant homology to other known replicase proteins (Rozanov et al., 1992). Longstaff et al. (1993) demonstrated its requirement for replication and RNA synthesis in protoplasts and Li et al. (1998) detected in vitro template-dependent RdRp activity of the bamboo mosaic virus (BaMV) replicase protein expressed and purified from E. coli.

Initially, in silico sequence comparisons with well characterized replicase genes revealed the replicase composition of supergroup III viruses, consisting of three functional domains: guanylyltransferase/methyltransferase-like (MT), RNA helicase-like (HEL) and polymerase-like domain (POL) (Koonin and Dolja, 1993) (Fig. 1B). Categorization following sequence homology enabled the assignment of the supergroup III MT domain to group 1, HEL domain to lineage 1 and POL domain to group III respectively (Van der 
Heijden and Bol, 2002). In Potexviruses, the three conserved domains are always expressed in the order MT-HEL-POL (from N- to C-terminus) in one single protein.

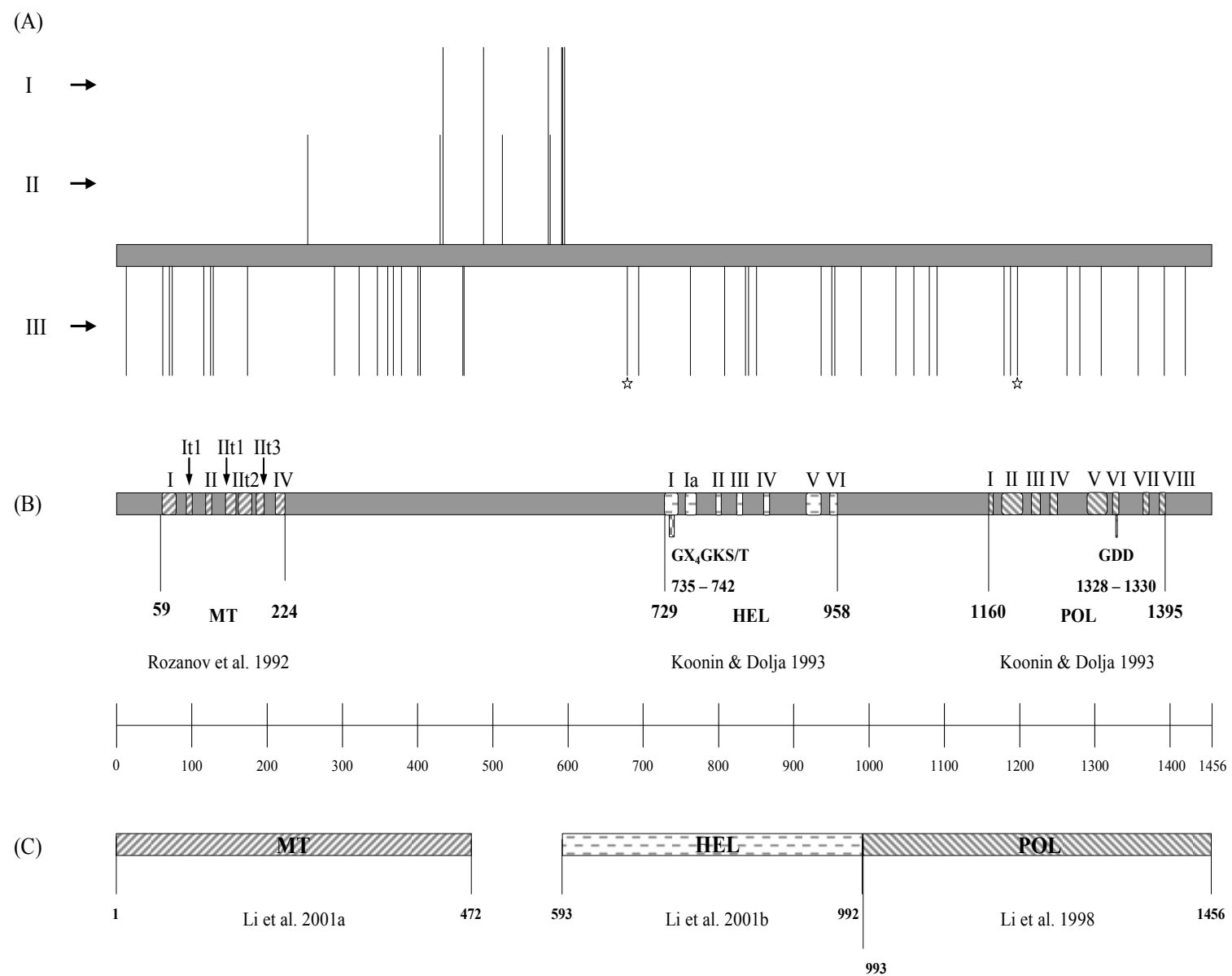

Fig. 1. Functional map of PVX replicase tolerance or sensitivity to 5 amino acids random insertions in relation to replication opposed to known conserved and functional domains. Amino acid numbering is according to PVX (GenBank Acc. no. $\underline{\mathbf{A Y 2 9 7 8 4 3}}$, pGr106). (A) PVX replicase pentapeptide scanning mutants created in this study displaying different degrees of replication ability (classes I-III; descriptions in the text and Table 1). ${ }^{*}$ Two independent insertion mutants at the same amino acid position with varying composition. (B) Replicase regions displaying conserved motifs (descriptions in the text) which previously enabled the prediction of methyltransferase (MT), RNA-helicase (HEL) and RNA-polymerase (POL) functions. (C) MT-, HEL- and POL functional domains of BaMV Potexvirus replicase identified in in vitro assays (Li et al., 2001a and b; Li et al., 1998) adapted to PVX replicase amino acid numbering.

Sequence comparison of the MT domain of different "Sindbis-like" viruses performed by Rozanov et al. (1992) resulted in the identification of seven distinct conserved motifs (I, It1, II, IIt1, IIt2, IIt3 and IV) in the MT (Fig. 1B). The authors detected motifs I, II and IV to contain an unvarying His residue, the AspXXArg signature 
(X is any amino acid) and an unvarying Tyr residue. Huang et al. (2005) and Li et al. (2001a) demonstrated for bamboo mosaic virus (BaMV) replicase that the N-terminal MT domain [amino acid (aa) 1 to 442 equivalent to $1-472$ in PVX], expressed in membrane fractions of yeast, formed a covalent linkage to the $\mathrm{m}^{7} \mathrm{GMP}$ moiety when it was incubated with GTP and AdoMet and therefore possesses methyltransferase and guanylyltransferase activities/capping activities (Fig. 1C). In addition the authors showed the presence of conserved His, Asp, and Arg residues in BaMV MT, initially identified by Rozanov et al. (1992).

The RNA HEL domain is localized in the central portion of the replicase protein, which consists of seven conserved motifs (called I, Ia, and II to VI) (Fig. 1B) (Gorbalenya and Koonin, 1993; Kadaré and Haenni, 1997). It possesses NTP-binding activity which is mediated by A and B sites. The motif I was shown to bind ATP or GTP and to carry the classical Walker 'A' ('P-Loop' or phosphate-binding loop) site whereas motif II constitutes the Walker ' $\mathrm{B}$ ' $\left(\mathrm{Mg}^{2+}\right.$-binding aspartic acid (D) motif) site (for review, see Caruthers and McKay, 2002). This NTP-binding/helicase motif contains a conserved glycine-lysine-serine (GX,GKS) amino acid sequence (Gorbalenya et al., 1989). Davenport and Baulcombe (1997) observed that mutations of the $\mathrm{GX}_{4} \mathrm{GKS}$ motif affected PVX RNA replication in vivo. The helicase proteins containing the NTP-binding motif (Gorbalenya et al., 1988; Hodgman, 1988) unwinds the nucleic acid duplexes into single strands using NTP as energy source (Bird et al., 1998) and are encoded by most of the positive-strand RNA viruses (Goregaoker and Culver, 2003; Vlot et al., 2001). The helicase is also assumed to play a role in translation, transcription and recombination and possibly in RNA splicing (Bird et al., 1998; Lohman and Bjornson, 1996). In a previous study of Li et al. (2001b), the E. coli expressed HEL domain (aa 514-892 equivalent to 593-992 in PVX) of BaMV replicase exhibited both NTP hydrolase and RNA 5'triphosphatase activities in vitro (Fig. 1C). Kalinina et al. $(1996,2002)$ have shown that the TGB1 of PVX, in addition to being indispensable for virus movement, possess NTPase/HEL domains and displays RNA helicase activities in vitro.

The POL activity is located as a catalytic domain in the C-terminal portion of the replicase protein and is required for replication of the viral genome (Ahlquist, 2002; Buck 1996; Kao et al., 2001; Lai, 1998). Kamer and Argos (1984) identified various amino acid sequence motifs common among putative replicase of several positive-stranded RNA viruses by means of comparative analysis of the amino acid sequences. Eight distinct (IVIII) conserved motifs have been identified in the POL domain of supergroup III RNA 
viruses (Fig. 1B) (Koonin, 1991; Poch et al., 1989). A hallmark of viral polymerases is the GDD (Gly-Asp-Asp) motif, which is assumed to be the active site of the PVX POL domain, as introduced point mutations destroyed virus infectivity (Hong and Hunt, 1996; Koonin and Dolja, 1993; Longstaff et al., 1993). Li et al. (1998) used E. coli expressed and purified BaMV replicase and deletion mutants thereof for an in vitro polymerase assay and were able to localize the catalytic domain to the C-terminal aa 893-1390 (corresponding to aa 993-1456 in PVX replicase protein). Huang et al. (2001) showed that the delimited BaMV POL domain still had the ability to bind specifically the 3' non-coding region of the viral RNA.

Despite experimental evidence for methyltransferase, helicase and polymerase activity of Potexvirus replicase produced in in vitro assays, the limits of the three functional domains was only roughly determined with a few deletion mutants for each domain (Li et al., 1998, 2001a, b). However, functional characterization of PVX replicase domains and their involvement in genome amplification has not been carried out in planta and to date mutational studies are not available.

Recent studies of the crystal structures obtained from 11 viral RdRps from different species mainly from the families Flaviviridae and Picornaviridae (Ferrer-Orta et al., 2006) have shown that they display a 3-dimensional conformation similar to DNA-dependent DNA polymerase (DdDp), DNA-dependent RNA polymerase (DdRp) and reverse transcriptase (RT) (reviewed in $\mathrm{Ng}$ et al., 2008). All of them consist of a basic right handlike shape with three subdomains, specific thumb, palm and finger. All RNA polymerases share six structural conserved motifs, which are located in the ubiquitous $\alpha \beta$ palm subdomain, including motifs A-F (reviewed in Ahlquist, 2002; Bruenn, 2003; Gorbalenya et al., 2002; O'Reilly and Kao, 1998). MT crystal structures of (+)-strand RNA viruses were mainly determined from members of the Flaviviridae (Egloff et al., 2002; Zhou et al., 2007). Most methyltransferases inside this family share a common 3D-structure referred to as a "SAM-dependent MTase fold", consisting of an open $\alpha / \beta / \alpha$ sandwich structure (reviewed in Zhou et al., 2007). 3D helicase structures have been established from organisms with more diverse origins, including yeast eIF4A (Caruthers et al., 2000), bacterial UvrB (Theis et al., 1999), Flavivirus YFV (Wu et al., 2005), bacteriophage T4 UvsW (Sickmier et al., 2004), bacterial RecQ (Bernstein et al., 2003), and HCV helicase (Yao et al., 1997, 1999). Common to all helicases is an NTPase active site at the interface of two domains whereas not all helicases possess an additional third domain. The single- 
stranded nucleic acid is bound in a cleft between the third domain and the two common domains (Wu et al., 2005).

Although the 3D-structure of a Potexvirus replicase or domains thereof have not been determined yet, we aimed to get an insight as to whether less structured regions in addition to conserved domains are necessary for the replication and genome amplification in vivo. We initially performed sequence alignment with replicase coding sequences of all members of the genus, where ever sequence information was available. According to former studies of Kekarainen et al. (2002), which initially applied pentapeptide scanning mutagenesis in a potyvirus genome to determine genome amplification functions, a random mutagenesis approach on the PVX replicase gene in viral background was applied. The results obtained were related to the known functionally characterized domains of MT, HEL and POL of the BaMV encoded model replicase and other supergroup III viruses.

\section{MATERIALS AND METHODS}

\section{Clones and infectious transcripts}

All standard cloning procedures were performed as described in Sambrook et al. (1989). The PVX full-length cDNA clone under control of the enhanced cauliflower mosaic virus (CaMV) 35S-promotor and polyadenylation signal (pA) in a binary vector for agroinfection (pGr106, Jones et al., 1999; Lu et al., 2003, GenBank accession no. $\underline{\text { AY297843) }}$ ) was kindly provided by David Baulcombe (Sainsbury Laboratory, Norwich, UK). It contains the full-length cDNA of PVX strain UK3 with doubled CP subgenomic promotor for expression of foreign genes (Chapman et al., 1992). In order to express GFP10 (Prasher et al., 1992) from pGr106, the $g f p$ open reading frame (ORF) was ClaISalI excised from pPVX204 (Baulcombe et al., 1995) and cloned into pGr106, resulting in 35S-PVX-GFP. To construct a movement-defective 35S-PVX-GFP CP-deletion mutant, a $\Delta 514-646$ nucleotide deletion was introduced into the CP consisting entirely of $237 \mathrm{aa} / 711$ nt, leading to a $\Delta 173-215$ aa deletion. This was achieved by subcloning a single-site (SalI and SpeI) PVX CP and 3'-non-translated region (3'-ntr) fragment from 35S-PVX-GFP and subsequently removing a CP-gene fragment (nt 514-646 in the CP ORF) between two $P v u I I$ restriction sites, followed by backcloning. The resulting plasmid was named 35SPVX-GFP- $\triangle$ CP.

To be able to detect PVX replicase expression from agroinfiltrated in vivo 35Sdriven PVX cDNA, the replicase was supplied with a c-myc affinity tag (EQKLISEEDLL) 
for immunological detection. Two primers with the c-myc sense and antisense coding sequence and two flanking BamHI sites were synthesized (sense: ggatccggagcaaaagttgatttctgaggaggatctttggatcc, BamHI restriction sites in italics), hybridized and cloned in-frame into the single BamHI site of the replicase gene (nt 1546 according to pGr106) in 35S-PVX-GFP, $-\triangle \mathrm{CP}$ and produced pentapeptide scanning (PS) mutants thereof. The correct orientation of each insert was verified through sequencing.

\section{PVX agroinfection assay}

35S-PVX-GFP, $-\triangle C P$ and mutants of this plasmid based on pGreen backbone, were co-electroporated with pSoup (Hellens et al., 2000) into Agrobacterium tumefaciens strain LBA4404 (Hoekema et al., 1983). Agroinfection was carried out according to Voinnet et al. (2000) with an $\mathrm{OD}_{600}=0.5$, using leaves of 4-week old Nicotiana benthamiana plants and infiltrating patches of $1.5 \mathrm{~cm}$ in diameter.

\section{Detection of PVX replication by epifluorescence microscopy (FM)}

$N$. benthamiana leaf patches agroinfected with $35 \mathrm{~S}-\mathrm{PVX}-\mathrm{GFP},-\triangle \mathrm{CP}$ and its mutants were monitored for PVX-expressed GFP fluorescence using epifluorescence microscopy (Leica DMR) equipped with a GFP filter (Sapph-GFP). Photographs were taken using Leica DFC camera, DFC300 FX.

\section{Random insertion scanning mutagenesis, mapping of the insertion and sequencing}

Generation of a pentapeptide scanning mutagenesis (PSM) library of the PVX RdRp/replicase ORF was carried out using the "Mutation Generation System" F701 $\mathrm{MGS}^{\mathrm{TM}}$ (Finnzymes) consisting of MuA transposase and entranceposon (M1-KanR) following the manufacturers instructions. An SphI (nt 575) - Bsp120I (nt 5948) fragment (nucleotide positions according to pGr106) containing the entire replicase ORF (nt 10875454) was subcloned into plasmid pSL1180 (Pharmacia) where the NotI site had been removed by Klenow fill-in reaction and religation. The resulting plasmid was used for PSM essentially as described in Varrelmann et al. (2007) and finally backcloning of the library into 35S-PVX-GFP- $\triangle \mathrm{CP}$ was carried out. PS mutants were used for mapping of the insertion by restriction digest and the exact position of the 15 nucleotide insertion was determined by sequencing. 


\section{Plant protein extraction and immunoblot analysis}

For c-myc tagged PVX replicase detection on immunoblots, total soluble plant proteins were extracted from agroinfiltrated $N$. benthamiana leaf patches using the method described by Harter et al. (1993) with modifications. $100 \mathrm{mg}$ agroinfiltrated leaf material was homogenized in liquid $\mathrm{N}_{2}$ before adding $500 \mu 195^{\circ} \mathrm{C}$ sample buffer [4M Urea, $4 \%$ SDS, $0.2 \mathrm{M}$ DTT, 20\% glycerol, $0.2 \mathrm{M}$ Tris/HCl (pH 6.8) and 0.04\% (w/v) bromophenol blue]. Samples were boiled for $10 \mathrm{~min}$ and cell debris was removed by centrifugation (5 min at $10.000 \mathrm{x} \mathrm{g}$ ). Supernatants $(40 \mu \mathrm{l})$ were separated on $10 \%$ SDS-PAGE gels and electroblotted on PVDF (Roche) membranes and blocked with TBS-T containing and 2\% skimmed milk. C-myc tag was probed with TBS-T diluted anti c-myc mouse monoclonal, IgG (Roche: cat. no. 11667149 001, 1:500) and alkaline phosphatase conjugated goat anti-mouse IgG (Biorad cat. no. 170-6520, 1:3000). Detection was performed with chromogenic substrates BCIP (5-bromo-4-chloro-3'-indoylphosphate p-toluidine salt) and NBT (nitro blue tetrazolium chloride) (Applichem).

\section{Sequence analysis}

All plasmid inserts were sequence verified using standard primers. Sequencing reactions were carried out by Eurofins MWG Operon, Martinsried, Germany. Sequence alignments (ClustalX) (Thompson et al., 1997) were carried out using DNAstar Lasergene Software (GATC Biotech, Germany). In silico manipulations of plasmids and primer design were performed with VectorNTI software (Invitrogen, Germany). 


\section{RESULTS}

\section{Replicase amino acid sequence alignment of genus Potexvirus species}

NCBI GenBank was searched for full-length replicase open reading frames of genus Potexvirus members. This resulted in the sequence identification of currently 16 different species including PVX. Only one replicase sequence per species (virus acronym and GenBank accession no. in brackets) was selected, namely bamboo mosaic virus

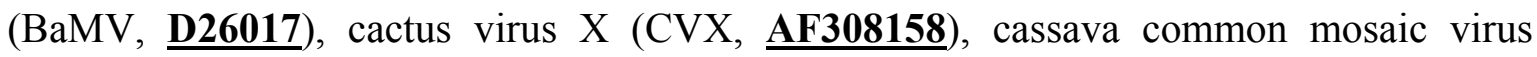

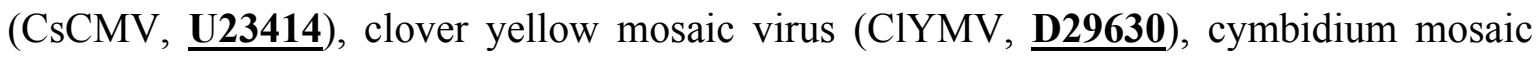
virus (CymMV, $\underline{\mathbf{U 6 2 9 6 3}}$ ), foxtail mosaic virus (FoMV, $\underline{\mathbf{A Y 1 2 1 8 3 3}}$ ), narcissus mosaic virus (NMV, D13747), papaya mosaic virus (PapMV, D13957), pepino mosaic virus (PepMV, $\underline{\mathbf{A F 4 8 4 2 5 1}}$ ), plantago asiatica mosaic virus (PlAMV, $\underline{\mathbf{Z 2 1 6 4 7}}$ ), potato aucuba mosaic virus (PAMV, $\underline{\mathbf{S 7 3 5 8 0}}$ ), potato virus X (PVX, $\underline{\mathbf{D 0 0 3 4 4}})$, scallion virus X (ScaVX, $\underline{\mathbf{A J 3 1 6 0 8 5}}$ ), strawberry mild yellow edge virus (SMYEV, D12517), tulip virus X (TVX, $\underline{\mathbf{A B 0 6 6 2 8 8}}$ ) and white clover mosaic virus (WClMV, $\underline{\mathbf{X 0 6 7 2 8}}$ ). To identify conserved regions and domains, nucleotide sequences were translated and ClustalX sequence alignment carried out. The results of the alignment are displayed in Fig. 2. The MT-, HELand POL domains including the conserved motifs as labelled in Fig. 1B were delineated above the alignment (Fig. 2) and listed here according to the PVX replicase sequence.

The guanylyl-/methyltransferase domain [amino acid (aa) 59-224] contains seven conserved motifs: I (aa 61-80), It1 (aa 93-101), II (aa 118-126), IIt1 (aa 145-160), IIt2 (aa 162-180), IIt3 (aa 186-197), and IV (aa 210-224) (numbers indicate aa positions in the replicase). The helicase domain (aa 729-958) as well is characterized by seven motifs: I (aa 729-747), Ia (aa 756-772), II (aa 797-804), III (aa 824-832), IV (aa 860-868), V (aa 917-937), and VI (aa 945-958). According to further analysis (Koonin and Dolja, 1993, Kadare and Haenni, 1997, Li et al., 2001b) the helicase domain contains several motifs conserved in the SF1 (superfamily 1) helicases: motifs I $\left({ }^{735} \mathrm{GAGGSGKS}^{742}\right)$, II $\quad\left({ }^{799}\right.$ IFDD $\left.^{802}\right)$, III $\quad\left({ }^{828}\right.$ GDSRQ $\left.^{832}\right), \quad$ V $\quad\left({ }^{921}\right.$ TYAGCQGLTKPKVQLV $\left.^{936}\right)$ and VI $\left({ }^{952} \mathrm{ALSR}^{955}\right)$. The motifs I and II of the helicase domain correspond to the NTP-binding ability. The RNA-polymerase domain (aa 1160-1395) consist of eight motifs: I (aa 11601166), II (aa 1177-1205), III (aa 1216-1228), IV (aa 1241-1251), V (aa 1290-1317), VI (aa 1324-1333), VII (aa 1365-1373), and VIII (aa 1387-1395). The GDD motif is located in motif VI $\left({ }^{1328} \mathrm{GDD}^{1330}\right)$. 

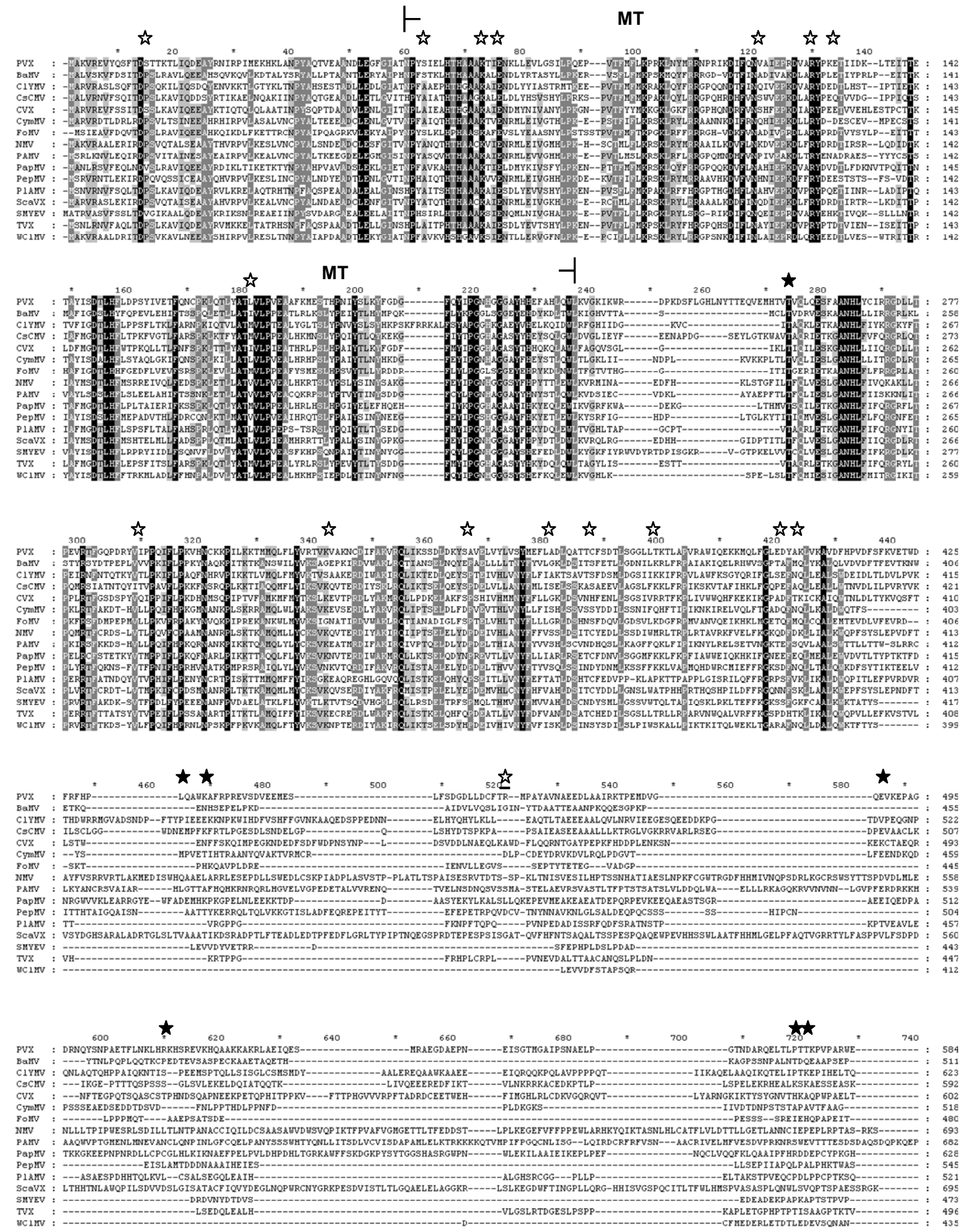
KAPITEL 2
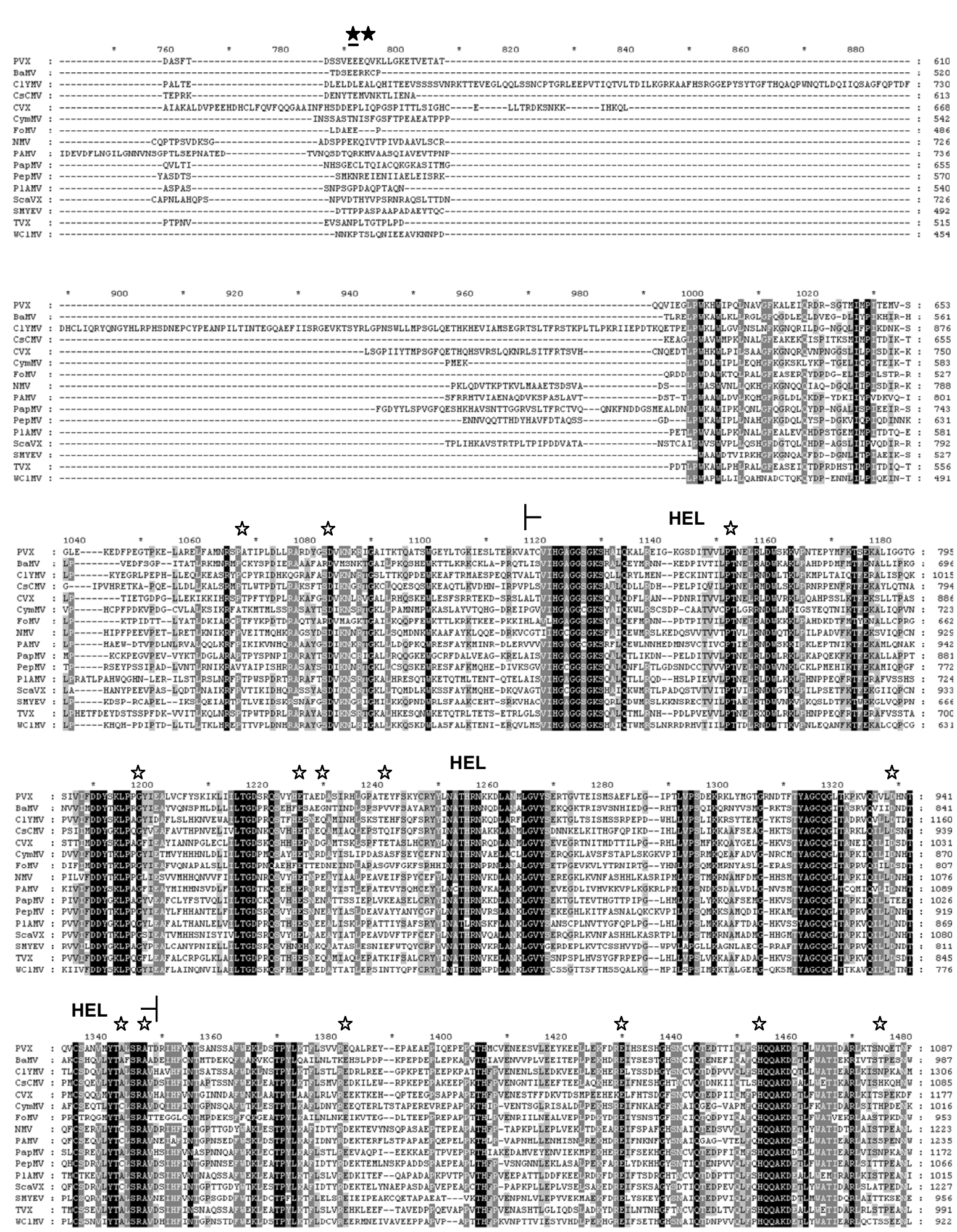

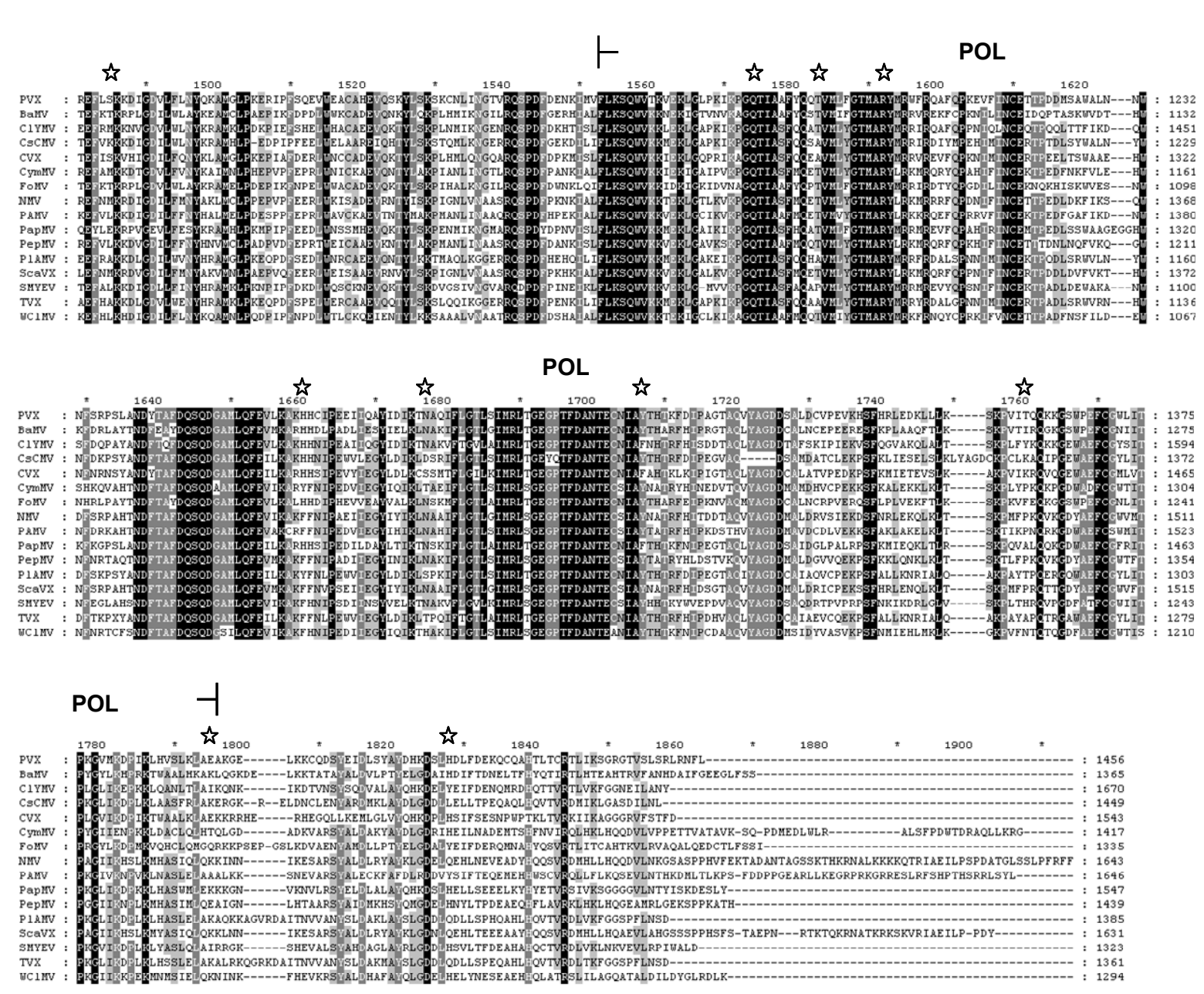

Fig. 2. ClustalX amino acid sequence alignment of replicase proteins of members of the genus Potexvirus (GenBank acc. nos. in brackets); BaMV - bamboo mosaic virus (ㄹ26017), CVX - cactus virus X

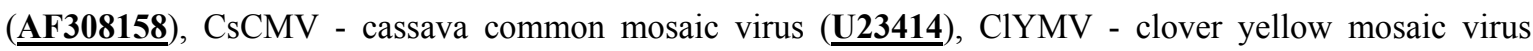

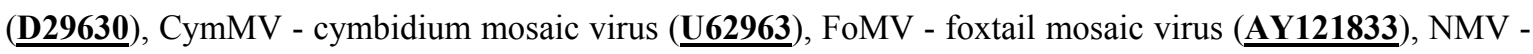

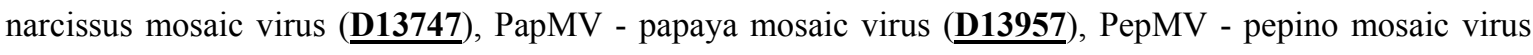

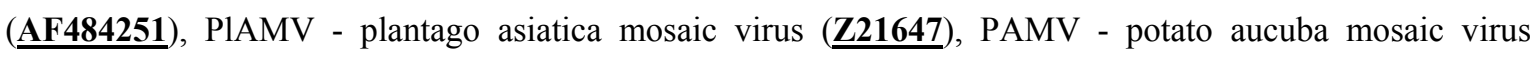

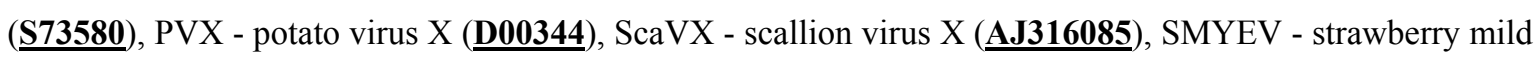

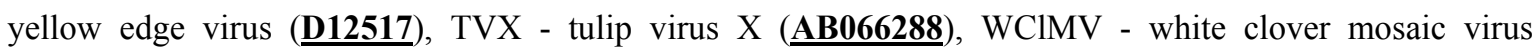
( $\underline{\mathbf{X 0 6 7 2 8}}$ ). Different grades of aa conservation are reflected by shading at four levels. The asterisks indicate the pentapeptide replicase insertion positions of the library mutants. A horizontal bar under an asterisk represents several mutants side by side. Filled asterisks indicate 10 independent insertion mutants not PSMaffected in their ability to replicate. The conserved domains methyltransferase (MT), helicase (HEL) and polymerase (POL) were delineated above the alignment. 
Interestingly, not all of these PVX-replicase motifs are strongly conserved in the defined region between the Potexvirus members aligned here (e.g. motif IIt1 of the MT-, motif Ia of the HEL- and motif VIII of the POL domain). In contrast, other domains conserved among all the members of Potexviruses were detected in the alignment which have neither been described nor analysed for their functional necessity, e.g. ${ }^{264} \mathrm{ANHL}^{267}$ and ${ }^{1061}$ HQQAKD ${ }^{1066}$ until now. The overall sequence homology of replicase between the different species ranged between $34.4 \%$ and $65.4 \%$ (data not shown). A remarkable but not unexpected result is, that regions with a high number of conserved amino acids were not uniformly distributed over the entire protein, instead regions of high and low homology alternated. According to the PVX aa sequence, two regions were highly conserved (aa 1-411 and 617-1437) in contrast to the hyper-variable region which displays deletions and insertions among the different species. Moreover, the extreme C-terminus of approximately aa 50 displayed variable length and composition between the species analysed.

\section{Construction of a PS library of the PVX replicase}

To identify regions and domains in the PVX replicase necessary for replication in vivo, the influence of random pentapeptide insertions in the viral replicase on replication, to be monitored by expression of subgenomic $g f p$ transcripts and GFP activity, was determined. Insertion mutagenesis was carried out and a library of replicase clones consisting of several hundred independent transformants was obtained. As viral background for the RdRp mutant library, a movement defective PVX mutant was chosen in order to allow replication monitoring only in primary infected cells. A faster spread of mutants with wild-type replication abilities would lead to a misinterpretation due to a strong relative increase of the GFP activity in comparison to debilitated mutants. After transferring the library into viral background (35S-PVX-GFP- $\Delta C P$ ), 210 clones were used for restriction enzyme mapping to verify the insertion and estimate the entranceposon footprint site. To determine the exact position of the 15 nucleotide sequence insertion (Table 1) 69 mutants with insertions almost randomly spread over the PVX replicase ORF were sequenced. Sequence analysis identified 54 independently isolated mutants. Seven mutants were isolated twice and four mutants thrice. Since the $15 \mathrm{nt}$ can be inserted in three different frames, this can result in different pentapeptide insertions following the same aa position. This was detected in two cases (679::CGRSP and CGRNP, 1198::MRPQA and AAAMA; replicase amino acid position followed by pentapeptide 
insertion). Four PS mutants of the TGB1 of PVX were excluded from further analysis (data not shown). As a total 52 different mutants were isolated and the replicase displays a size of 1456 aa, it was calculated that the library generated contained an average density of one insertion per 28 aa (Fig. 1A).

\section{Table 1}

Effect of Entranceposon insertion mutations in the 35S-PVX-GFP- $\Delta$ CP replicase open reading frame on replication monitored by subgenomic RNA synthesis, following agroinfection

\begin{tabular}{|c|c|c|c|}
\hline $\begin{array}{c}\text { PVX replicase mutant } \\
\text { no. } \\
\end{array}$ & $\begin{array}{c}\text { Pentapeptide insertion } \\
\text { position (aa) } \\
\end{array}$ & Inserted pentapeptide & Ps-mutant class \\
\hline 1 & 13 & AAATD & III \\
\hline 2 & 61 & CGRTY & III \\
\hline 3 & 71 & NAAAA & III \\
\hline 4 & 74 & VRPHI & III \\
\hline 5 & 116 & CGRKN & III \\
\hline 6 & 125 & SAAAA & III \\
\hline $7+8$ & 129 & CGRTK & III \\
\hline 9 & 174 & AAAAT & III \\
\hline $10+11$ & 254 & AAATV & II \\
\hline 12 & 290 & AAAYV & III \\
\hline 13 & 323 & CGRIK & III \\
\hline 14 & 347 & AAAYS & III \\
\hline 15 & 361 & CGRIL & III \\
\hline 16 & 368 & CRPHT & III \\
\hline 17 & 379 & MRPQL & III \\
\hline $18+19+20$ & 401 & VRPHE & III \\
\hline 21 & 404 & NAAAA & III \\
\hline 22 & 430 & LRPHP & II \\
\hline $23+24+25$ & 434 & MRPQW & I \\
\hline 26 & 461 & MRPHF & III \\
\hline 27 & 462 & SAAAT & III \\
\hline $28+29$ & 488 & CGRSQ & I \\
\hline $30+31$ & 513 & CGRNR & II \\
\hline 32 & 574 & MRPHP & I \\
\hline 33 & 576 & AAATT & II \\
\hline 34 & 592 & CGRTS & I \\
\hline $35+36$ & 593 & DAAAV & I \\
\hline $37+38+39$ & 595 & VRPQE & I \\
\hline 40 & 679 & CGRSP & III \\
\hline 41 & 679 & CGRNP & III \\
\hline 42 & 694 & AAAGS & III \\
\hline 43 & 763 & MRPQP & III \\
\hline $44+45$ & 808 & VRPHP & III \\
\hline
\end{tabular}


KAPITEL 2

\begin{tabular}{|cccc|}
\hline 46 & 836 & & III \\
47 & 840 & CGRNH & III \\
$48+49+50$ & 851 & III \\
51 & 937 & VRPQT & III \\
52 & 951 & VRPHT & III \\
53 & 955 & CGRTR & III \\
54 & 990 & VRPQR & III \\
55 & 1036 & CGRNR & III \\
56 & 1060 & LRPHS & III \\
57 & 1081 & AAATS & III \\
58 & 1091 & CGRIL & III \\
59 & 1180 & CGRTG & III \\
60 & 1189 & MRPQQ & III \\
$\mathbf{6 1}+\mathbf{6 2}$ & $\mathbf{1 1 9 8}$ & MRPQA & III \\
$\mathbf{6 3}$ & $\mathbf{1 1 9 8}$ & AAAMA & III \\
64 & 1263 & LRPHK & III \\
66 & 1280 & AAAKT & III \\
67 & 1310 & AAAIA & III \\
\hline
\end{tabular}

Replication mutant class I, GFP fluorescence similar to agroinfected 35 S-PVX-GFP- $\triangle$ CP carrying wild-type replicase; class II, GFP fluorescence visible but lower than 35S-PVX-GFP- $\triangle \mathrm{CP}$; class III, non-detectable GFP fluorescence. The bold face type indicates the two independent insertion mutants at the same amino acid position with varying composition. The Amino acid position of $35 \mathrm{~S}-\mathrm{PVX}-\mathrm{GFP}-\triangle \mathrm{CP}$ replicase is according to GenBank accession no. $\underline{\mathbf{A Y 2 9 7 8 4 3}}$.

\section{Transient Agrobacterium mediated expression assay of replicase PS-mutants}

To monitor the replication activity using GFP expression from subgenomic viral RNA of the movement defective PVX PS-mutants, the 69 mutants of the library were mobilized into A. tumefaciens and used for infiltration of $N$. benthamiana leaves (four leaves in triplicates). As controls $35 \mathrm{~S}-\mathrm{PVX}-\mathrm{GFP}$ and $-\Delta \mathrm{CP}$ were applied. GFP fluorescence of leaf parenchyma tissue was monitored under FM at 5 dpi and compared with parallel infiltrated controls (35S-PVX-GFP and - $\triangle \mathrm{CP}$ ) (Fig. 3). Results were consistent in all repetitions of the assay. $N$. benthamiana leaf tissue infiltrated with 35S-PVX-GFP displayed much stronger fluorescence, confirmed under FM examination as higher number of fluorescing cells, compared to the CP-deletion mutant 35S-PVX-GFP- $\triangle \mathrm{CP}$ and all -PSmutants (Fig. 3). As the CP-deletion completely abolished short- and long-distance movement in $N$. benthamiana leaves, the virus expressed GFP fluorescence of the CP defective PVX mutant (- $\Delta \mathrm{CP})$, like all PS-mutants, was limited to the agroinfiltrated leaf 
patches. Replicase PS mutants with strongly reduced GFP fluorescence (replication activity) below the visual detection level in the agroinfiltrated area at 5 dpi were classified into class III (FM data not shown). Mutants with restricted replication ability (detectable GFP fluorescence) compared to $35 \mathrm{~S}-\mathrm{PVX}-\mathrm{GFP}-\Delta \mathrm{CP}$ were grouped into class II. Replicase mutants with strong GFP fluorescence similar to $35 \mathrm{~S}-\mathrm{PVX}-\mathrm{GFP}-\triangle \mathrm{CP}$ were assigned to class I (Fig. 3 and Table 1). Taken together, 10 independent PS-mutants from 69 displayed replication activity with variable intensity of GFP fluorescence.

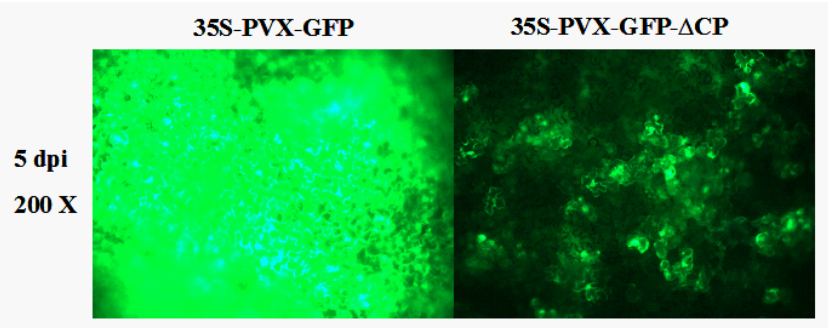

35S-PVX-GFP- $\Delta$ CP-
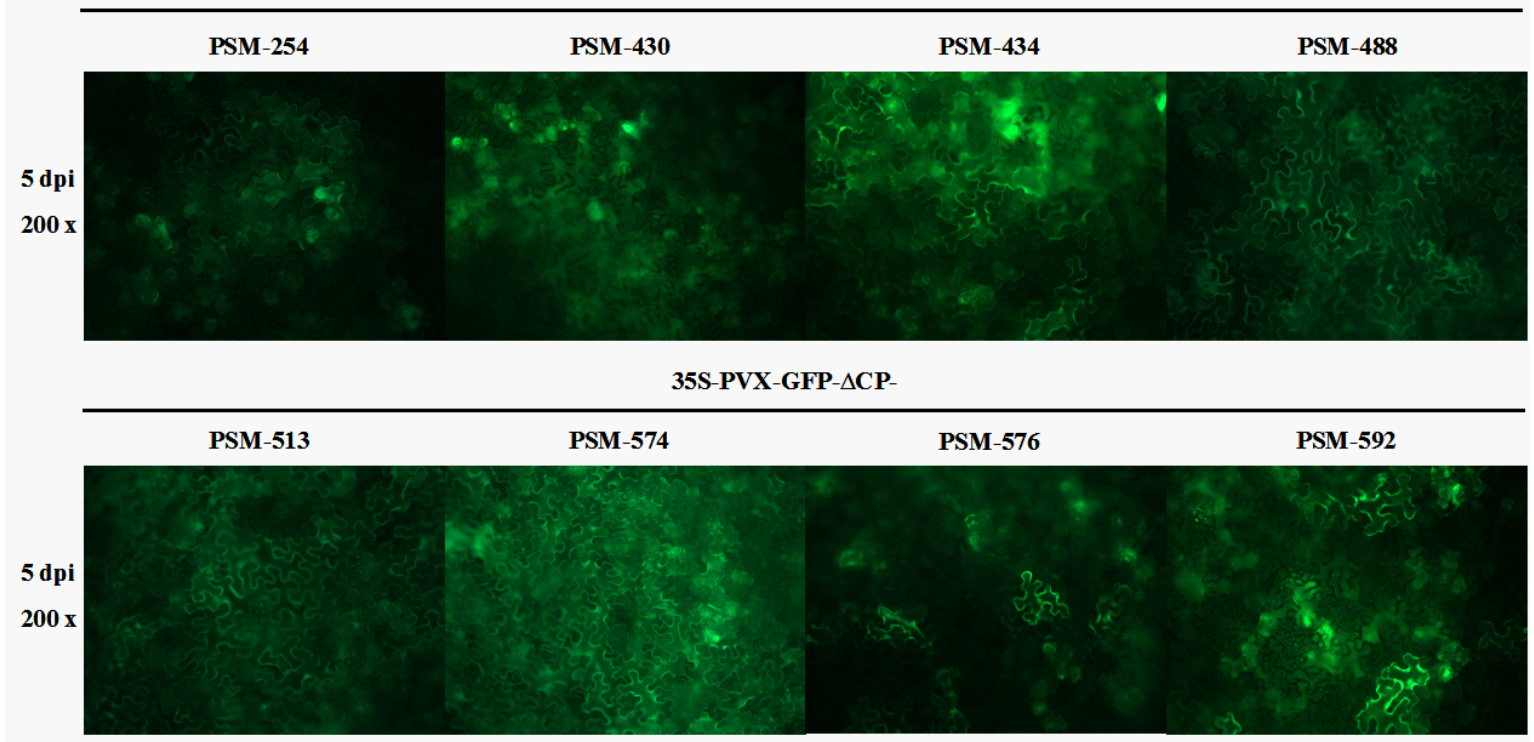

35S-PVX-GFP- $\triangle$ CP

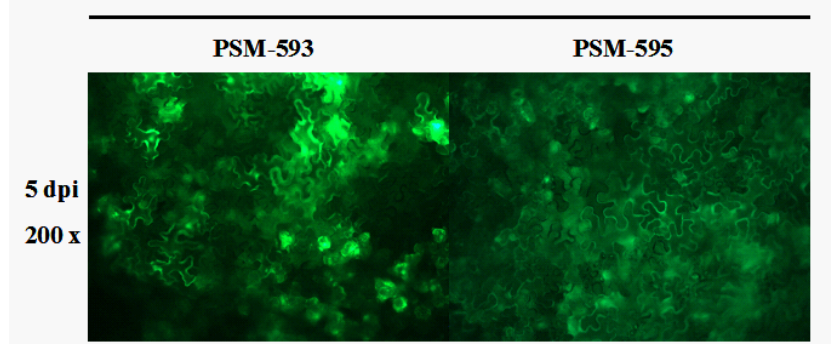

Fig. 3. Epifluorescence microscopy pictures of $N$. benthamiana parenchyma cells agroinfected with 35S-PVX-GFP, $-\triangle \mathrm{CP}$ and pentapeptide scanning mutants (pentapeptide insertion as designated in Table 1) respectively and monitored at 5 dpi using 200-fold magnification with a GFP-filter. 


\section{Influence of pentapeptide insertions on PVX replicase protein stability}

The possibility remained, that the replicase pentapeptide insertions at varying positions did not interfere with the replication function but instead with the stability or expression level of the protein. As no PVX replicase specific antiserum was available for immunological detection, the coding sequence for c-myc tag was inserted in the replicase-ORF leading to an insertion of 11 aa and doubling of 2 aa in the protein between replicase aa 155-56 in PVX-GFP background (35S-PVX-GFP-c-myc). 35S-PVX-GFP-cmyc was applied for $N$. benthamiana agroinfection but neither replication (GFP fluorescence) nor movement was observed. Although the replication ability of replicase-cmyc was abolished, immunodetection from total protein extracts at 5 dpi resulted in a clear signal with the expected replicase size of approximately $166 \mathrm{kDa}$ (Fig. 4), proving the suitability of the expression assay. Subsequently, the c-myc tag was transferred into 35SPVX-GFP- $\triangle \mathrm{CP}$ and ten different PS-mutants [two replication active- (430::LRPHP, 434::MRPQW) and eight inactive mutants (13::AAATD, 74::VRPHI, 401::VRPHE, 679::CGRSP, 763::MRPQP, 951::VRPHT, 1180::CGRTG, 1420::LRPHL, see also Table 1]. Agroinfiltration was performed and subsequent immunodetection at 5 dpi showed that c-myc tagged replicase of 35S-PVX-GFP- $\triangle$ CP-c-myc and all PS-mutants derived thereof were translated from $35 \mathrm{~S}$ transcripts at comparable levels. These results supplied evidence that even the pentapeptide insertion plus c-myc tag did not negatively interfere with the protein stability in any of the mutants tested.

(A)

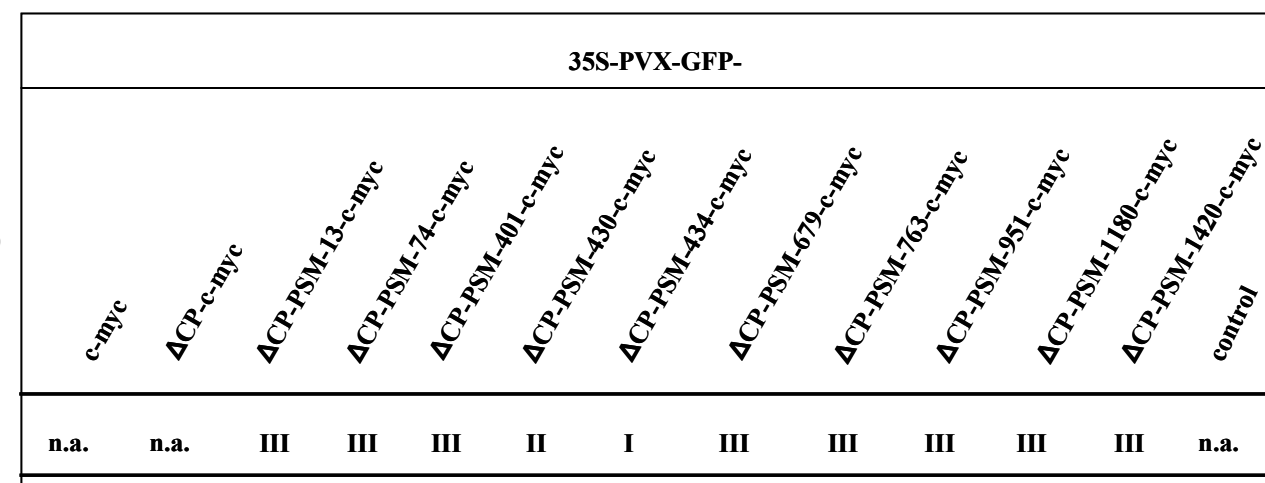

(C)

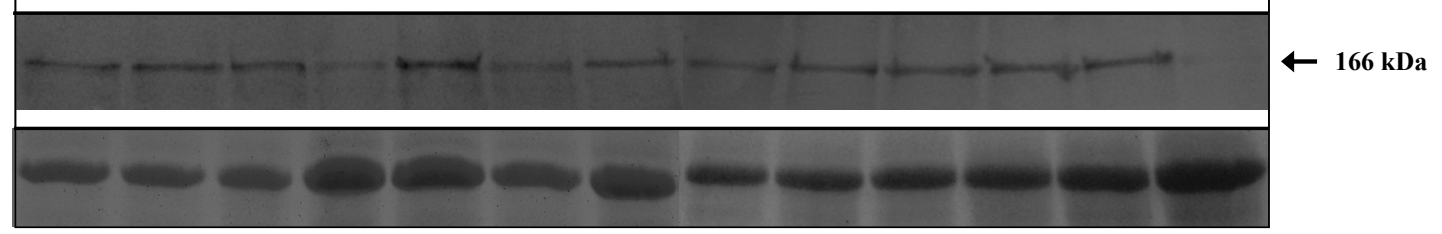

Fig. 4. Immunodetection of different PVX replicase c-myc tagged pentapeptide insertion mutants using c-myc specific antiserum in total protein extracts from agroinfiltrated $N$. benthamiana leaf tissue. (A) 
35S-PVX-GFP- $\triangle$ CP-PSM, mutant designation (c-myc tagged) number refers to peptide insertion position in replicase. The control represents 35S-PVX-GFP without c-myc tag. (B) Mutant class of PVX PS-mutant without c-myc tag according to Table 1, n.a.: not accessible. (C) Immunodetection of replicase, (D) Corresponding PAGE Coomassie-stained loading control.

\section{Construction of a functional map of PVX replicase referring to replication in vivo}

The categorization of PVX replicase replication/genome amplification abilities into functional classes depending on pentapeptide insertions as monitored by GFP expression of 69 PS mutants allowed us to construct a dense functional map of the PVX replicase (Fig. 1A and Table 1). Of the 69 PS-mutants analysed, 51 were categorized into class III, six were class II and 12 were class I, including PS-mutants isolated twice and thrice. Mutants isolated twice from the library are displayed only once in the functional map, whereas the two mutants with two independent insertions at the same amino acid position with varying composition were labelled with an asterisk (Fig. 1A). Visual examination of GFP expression finally resulted in a total of 52 PS-mutants of PVX replicase to map the effect of replicase ORF pentapeptide insertions on replication (Fig. 1A). Six PS-mutants displayed replication ability similar to wild-type PVX replicase protein (class I), four PS-mutants were sorted into class II and 42 showed no detectable replication function (class III). In the N-terminal 404 amino acids (PS-mutant no. 1-21, Fig. 1A and Table 1) only one functional PS-mutant (PS-mutant no. 11, class II) was detected. All other mutants in this region were class III mutants without detectable replication ability. Obviously, mutations which did not induce significant or imposed only minor effects on the replicase proteins ability to replicate were discovered only in the region from aa 430-595 (PS-mutants 430::LRPHP, 434::MRPQW, 488::CGRSQ, 513::CGRNR, 574::MRPHP, 576::AAATT, 592::CGRTS, 593::DAAAV, 595::VRPQE, displayed in Table 1). The entire C-terminal half of the protein including HEL- and POL domain was highly intolerant to the pentapeptide insertion as demonstrated by 24 independent mutants spread more or less uniformly. 


\section{DISCUSSION}

Structural conserved domains identified in sequence alignments of $(+)$-strand RNA viruses (Koonin, 1991, Koonin \& Dolja, 1993, Rozanov et al., 1992) initially led to the distinct separation of putative MT-, HEL- and POL domains. These conserved regions however encompass only limited regions in the Potexvirus replicase of 1456 aa (aa 59-224 MT, 729-958 HEL and 1160-1395 POL domain in PVX replicase, Fig. 1B). This raised the question, whether the regions in between also possess functional importance as to the ability of the protein to drive RNA replication functions since previous studies with BaMV only demonstrated approximate separation of Potexvirus replicase MT-, HEL- and POL domains with different distinct biochemical activities (Li et al., 1998, 2001a, b).

In this study we have performed for the first time a Potexvirus replicase sequence comparison with all full-length sequences available and Re-investigation of the conserved MT HEL and POL domains and previously identified sequence motifs within (Fig. 1B) confirmed conservation for most of them. In contrast to former studies (Liou et al., 2004; Van der Vlugt and Berendsen, 2002) that analysed the conserved domains separately, in our hands ClustalX software tolerated the hyper-variable region when 16 species replicase sequences were aligned. However, additional aa stretches in every separated functional domain, displaying a high degree of conservation at least in Potexviruses were identified, suggesting evolution by genus specific adaptation and necessity for the proteins function. Remarkably, the hydrophilic linker region between MT- and HEL domain of ca. 100 aa in length, suggested by Han et al. (2007) and Li et al. (2001a) to represent a "disordered region" in BaMV replicase showed the highest variability in length and composition between different Potexvirus species in the alignment (Fig. 2). This suggests that MT and HEL plus POL regions are separated by a highly-variable linker sequence, whose functional involvement has not been investigated yet (Fig. 1C).

To prove the involvement of the different conserved and less conserved replicase regions in the proteins ability to drive virus replication and genome amplification in vivo, we performed a systematic functional analysis of a plant RNA virus replicase in virus background for the first time. The availability of a PVX GFP-labelled full-length clone suitable for agroinfection plus the powerful and versatile random pentapeptide insertion scanning mutagenesis enabled the fast production of a library with 54 independent mutants which was subsequently tested for genome amplification via indirect quantification of subgenomic RNA expression. 
The relative visual rating of virus encoded GFP fluorescence and assignment to categories was consistent in all independent repetitions of the assay. The validity of the assay is strengthened by the fact that all mutants isolated twice or thrice from the pooled library displayed exactly the same functional class in the replication assay. The insertion of 13 additional aa (c-myc) at replicase aa position 155, expected to lead to disruption of genome amplification (Fig. 4), did not interfere obviously with the 35S-driven protein expression level. The tag allowed immunological detection of the wild type replicase as well as many different PS-mutants which proved detectable replicase expression levels independent of the pentapeptide insertion. This supports the conclusion that the observed replication phenotype could be ascribed to the proteins functionality in viral background.

Compared to previous studies applying PS mutagenesis for functional characterisation of proteins (Fransen et al., 2005; Ghazala et al., 2008; Poussu et al., 2004; Varrelmann et al., 2007) this study provides another example of pentapeptide insertions that do not seem to interfere with the stability of the protein. All previous studies applied the same mutagenesis system and verified mutant protein stability in E. coli, yeast and in planta, following transient agrobacterium mediated expression, respectively by use of specific antibodies. In all studies, only a very low percentage of PS-mutants displayed unstable protein expression. Although the 54 PS library mutants at independent positions led to a calculated average density of one mutant per 28 aa, the functional map of the replicase displayed some gaps, namely between PS-mutant no. 9-10 (aa 80), 39-40 (aa 84), 50-51 (aa 86) and 58-59 (aa 89) (Figure 1A and Table 1). These regions have to be excluded from further evaluation and future studies applying PSM with larger genes should consider to start with significantly more than 210 clones to obtain a library from a $4368 \mathrm{bp}$ gene with a higher density. Comparison of the PVX functional replication map obtained with the application of PSM (Fig. 1A) to the conserved domains of plant RNA virus replicases (Fig. 1B) and the delimited functional replicase domains of BaMV showed striking convergence. We expected that insertions in the MT domain conserved among RNA viruses would strongly interfere with replication in vivo. However, the high number of mutants adjacent to the C-terminal part of the conserved MT domain (covered by PSmutant no. 12-21) together with the high density of conserved aa in the alignment in that region (Fig. 2) suggests that this part is also necessary for the functionality of the MT (guanylyl-/methyltransferase) function. Apparently the positions of the different pentapeptide insertions in the MT region show that the disrupting influence seemed to be independent of the conservation of the surrounding sequence stretches, although it remains 
speculative, whether an insertion interferes directly with the function or indirectly via the proteins secondary structure. In addition, the possibility remains, however, that replication phenotypes of the mutants could result from altered secondary/tertiary RNA structures important for RNA synthesis, which was not investigate here. The highly variable linker region corresponding to PVX replicase region aa 410-619 (Fig. 2) was consistent with high replication tolerance to the pentapeptide insertion, covered by PS mutant no. 22 to 39 . This supports the biochemical studies of BaMV MT- and HEL replicase deletion clones which have shown that this part is dispensable for the enzymatic guanylyl-/methyltransferase and RNA 5'-triphosphatase/NTPase functions (Fig. 1C). However, two mutations in that region in short distance (PS-mutant no. 26 and 27, aa 461 and 462, respectively) were intolerant to the insertion, suggesting that the linker might possess at least some importance in vivo, possibly by connecting the domains or mediating an interaction of them.

Point mutational studies of the Potexvirus replicase function in viral background, were performed in the past with highly conserved HEL (GKS) and POL (GDD) motifs (Longstaff et al., 1993; Davenport \& Baulcombe, 1997). Han et al. (2007) investigated each BaMV HEL conserved motif versus its influence on virus replication in planta by alanine substitution mutagenesis, to relate biochemical activity and sequence conservation. Only two out of seven mutants displayed virus replication. The first active mutant was equivalent to a substitution at aa 635 in PVX replicase in the hyper-variable region and was confirmed in our findings obtained through pentapeptide insertion. The second BaMV replicase mutant (HEL motif VI) (equivalent to aa 958 in PVX replicase) also displayed replication activity, this contradicts our observations, where all insertions inside the conserved HEL domain were deleterious for genome amplification. All other alanine mutants in conserved HEL domains (I-V) were abolished in replication ability in BaMV viral background.

As all PS-mutants beyond position aa 697 (PS-mutant no. 40-69) were detrimental for virus replication, independent of whether the insertion was interfering with structural conserved known HEL and POL sequence motifs, putative active sites or inter-regions, differentiating conclusions are difficult to draw. Previous PSM studies on proteins with known 3D structure (Hallet et al., 1997; Petyuk et al., 2004; Poussu et al., 2004) have shown that in most effective pentapeptide insertions cases locate to the proximity to an active site of a protein or disrupt the secondary structure of the target. The most plausible explanation for this high sensitivity of HEL and POL regions is that the aa sequence composition of the two adjacent domains, although interspecies sequence homology is 
estimated to be not above 63\% (HEL domain) and 69\% (POL) respectively in both regions (Liou et al., 2004), is an imperative for the viral replication function in vivo.

In future, biochemical analysis of the PS-mutants of the replicase-ORF constructed in this study should be performed to assign the replication defects to the distinct domain functions as carried out for the BaMV HEL domain by Han et al. (2007). To understand the function of the hyper-variable region better, deletion mutants should be established and tested for their replication abilities. Further 3D structural analysis of PVX replicase and subdomains is evidently required to understand the influence of PS mutagenesis on the replicase structure and function in detail.

\section{ACKNOWLEDGMENTS}

We kindly acknowledge Prof. David Baulcombe for the gift of pGR106 vector. D. Silhavy is acknowledged for providing the pBIN61S plasmid. Heidrun-Katharina Draghici was sponsored by a research fellowship (grant no. VA202/3-2) of the Deutsche Forschungsgemeinschaft (DFG).

\section{REFERENCES}

Adams, M.J., Antoniw, J.F., Bar-Joseph, M., Brunt, A.A., Candresse, T., Foster, G.D., Martelli, G.P., Milne, R.G., Fauquet, C.M., 2004. The new plant virus family Flexiviridae and assessment of molecular criteria for species demarcation. Arch. Virol. 149, 1045-1060.

Ahlquist, P., 2002. RNA-dependent RNA polymerases, viruses, and RNA silencing. Science 296, 1270-1273.

Batten, J.S., Yoshinari, S., Hemenway, C., 2003. Potato virus X: a model system for virus replication, movement and gene expression. Mol. Plant Pathol. 4, 125-131.

Baulcombe, D.C., Chapman S., Santa Cruz, S., 1995. Jellyfish green fluorescent protein as a reporter for virus infections. The Plant Journal 7, 1045-1053. 
Bernstein, D.A., Zittel, M.C., Keck, J.L., 2003. High-resolution structure of the E.coli RecQ helicase catalytic core. EMBO J. 22, 4910-4921.

Bird, L.E., Subramanya, H.S., Wigley, D.B., 1998. Helicases: a unifying structural theme? Curr. Opin. Struct. Biol. 8, 14-18.

Bressanelli, S., Tomei, L., Roussel, A., Incitti, I., Vitale, R.L., Mathieu, M., De Francesco, R., Rey, F.A., 1999. Crystal structure of the RNA-dependent RNA polymerase of hepatitis C virus. Proc. Natl Acad. Sci. USA, 96, 13034-13039.

Buck, K.W., 1996. Comparison of the replication of positive-stranded RNA viruses of plants and animals. Adv. Virus Res. 47, 159-251.

Bruenn, J.A., 2003. A structural and primary sequence comparison of the viral RNAdependent RNA polymerases. Nucleic. Acids. Research. 31(7), 1821-829.

Caruthers, J.M., Johnson, E.R., McKay, D.B., 2000. Crystal structure of yeast initiation factor 4A, a DEAD-box RNA helicase. Proc. Natl. Acad. Sci. USA 97, 1308013085 .

Caruthers, J.M., McKay, D.B., 2002. Helicase structure and mechanism. Curr. Opin. Struct. Biol. 12, 123-133.

Chapman, S., Kavanagh, T., Baulcombe, D.C., 1992. Potato virus X as a vector for gene expression in plants. The Plant Journal 2, 549-557.

Cheng, C.P., Tsai, C.H., 1999. Structural and functional analysis of the 39 untranslated region of bamboo mosaic potexvirus genomic RNA. J Mol Biol 288, 555-565.

Cheng, J. H., Peng, C.W., Hsu, Y.H., Tsai, C.H., 2002. The synthesis of minus-strand RNA of bamboo mosaic potexvirus initiates from multiple sites within the poly(A) tail. J. Virol. 76, 6114-6120. 
Chiu, W.W., Hsu, Y.H., Tsai, C.H., 2002. Specificity analysis of the conserved hexanucleotides for the replication of bamboo mosaic potexvirus RNA. Virus. Res. 83, 159-167.

Davenport, G.F., Baulcombe, D.C., 1997. Mutation of the GKS motif of the RNAdependent RNA polymerase from potato virus $\mathrm{X}$ disables or eliminates virus replication. J. Gen. Virol. 78, 1247-1251.

Egloff, M.P., Benarroch, D., Selisko, B., Romette, J.L., Canard, B., 2002. An RNA cap (nucleoside-2'-O-)-methyltransferase in the flavivirus RNA polymerase NS5: crystal structure und functional characterization. EMBO J. 21 (11), 2757-2768.

Ferrer-Orta, C., Ariás, A., Agudo, R., Perez-Luque, R., Escarmis, C., Domingo, E., Verdaguer, N., 2006. The structure of a protein primer-polymerase complex in the initiation of genome replication. EMBO J. 25, 880-888.

Fransen, M., Vastiau, I., Brees, C., Brys, V., Mannaerts, G.P., Van Veldhoven, P.P., 2005. Analysis of human Pex19p's domain structure by pentapeptide scanning mutagenesis. J. Mol. Biol. 346, 1275-1286.

Ghazala, W., Waltermann, A., Pilot, R., Winter, S., Varrelmann, M., 2008. Functional characterization and subcellular localization of the $16 \mathrm{~K}$ cysteine-rich suppressor of gene silencing protein of Tobacco rattle virus. J. Virol. 89(Pt 7), 1748-1758.

Gorbalenya, A.E., Koonin, E.V., Donchenko, A.P., Blinov, V.M., 1988. A conserved NTPmotif in putative helicases. Nature 333, 22.

Gorbalenya, A.E., Blinov, V.M., Donchenko, A.P., Koonin, E.V., 1989. An NTP-binding motif is the most conserved sequence in a highly diverged monophyletic group of proteins involved in positive strand RNA viral replication. J. Mol. Evol. 28, 256268.

Gorbalenya, A.E., Koonin, E.V., 1993. Helicases: amino acid sequence comparisons and structure-function relationships. Curr. Opin. Struct. Biol. 3, 419-429. 
Gorbalenya, A.E., Pringle, F.M., Zeddam , J.-L., Luke, B.T., Cameron, C.E., Kalmakoff, J., Hanzlik, T.N., Gordon, K.H.J., Ward, V.K. 2002. The Palm Subdomain-based Active Site is Internally Permuted in Viral RNA-dependent RNA Polymerases of an Ancient Lineage. J. Mol. Biol. 324, 47-62.

Goregaoker, S.P., Culver, J.N., 2003. Oligomerization and activity of the helicase domain of the tobacco mosaic virus 126- and 183-kilodalten replicase proteins. J.Virol. 77, $3549-3556$.

Hallet, B., Sherratt, D.J., Hayes, F., 1997. Pentapeptide scanning mutagenesis: random insertion of a variable five amino acid cassette in a target protein. Nucleic Acids Res. 25, 1866-1867.

Han, Y.T., Tsai, C.S., Chen, Y.C., Lin, M.K., Hsu, Y.H., Meng, M., 2007. Mutational analysis of a helicase motif-based RNA 5'-triphosphatase/NTPase from bamboo mosaic virus. Virology 367 (1), 41-50.

Harter, K., Talke-Messerer, C., Barz, W., Schäfer, E., 1993. Light and sucrose-dependent gene expression in photomixotrophic cell suspension cultures and protoplasts of rape (Brassica napus L.). Plant J. 4, 507-516.

Hellens, R.P., Edwards, E.A., Leyland, N.R., Bean, S., Mullineaux, P.M., 2000. pGreen: a versatile and flexible binary $\mathrm{Ti}$ vector for Agrobacterium-mediated plant transformation. Plant Molecular Biology 42, 819-832.

Hodgman, T., 1988. A new superfamily of replicative proteins. Nature 333, 22-23.

Hoekema, A., Hirsch, P.R., Hooykaas, P.J.J., Schilperoort, R.A., 1983. A binary plant vector strategy based on separation of vir- and T- region of the Agrobacterium tumefaciens Ti-plasmid. Nature 303, 179-180.

Hong, Y., Hunt, A.G., 1996. RNA polymerase activity catalyzed by a potyvirus-encoded RNA-dependent RNA polymerase. Virology 226, 146-151. 
Huang, C.-Y., Huang, Y.-L., Meng, M., Hsu, Y.-H., and Tsai, C.-H., 2001.Sequences at the 3'Untranslated Region of Bamboo Mosaic Potexvirus RNA Interact with the Viral RNA-Dependent RNA Polymerase. J. Virol. 75, 2818-2824.

Huang, Y.L., Hsu, Y.H., Han, Y.T., Meng, M., 2005. mRNA guanylation catalyzed by the S-adenosylmethionine-dependent guanylyltransferase of bamboo mosaic virus. J. Biol. Chem. 280, 13153-13162.

Jones, L., Hamilton, A.J., Voinnet, O., Thomas, C.L., Maule, A.J., Baulcombe, D.C., 1999. RNA-DNA interactions and DNA methylation in post-transcriptional gene silencing. Plant Cell 11, 2291-2301.

Kadaré, G, Haenni, A.L., 1997. Virus encoded RNA helicases. J. Virol. 71, 2583-2590.

Kalinina, N.O., Fedorkin, O.N., Samuilova, O.V., Maiss, E., Korpela, T., Morozov, S.Y., Atabekov, J.G., 1996. Expression and biochemical analyses of the recombinant potato virus X, 25K movement protein. FEBS Lett. 397, 75-78.

Kalinina, N.O., Rakitina, D.V., Solovyev, A.G., Schiemann, J., Morozov, S.Y., 2002. RNA helicase activity of the plant virus movement proteins encoded by the first gene of the triple gene block. Virology, 296, 321-329.

Kamer, G., Argos, P., 1984. Primary structural comparisons of RNA-dependent polymerases from plant, animal and bacterial viruses. Nucl. Acids Res. 12, 7269 7282.

Kao, C.C., Singh, P., Ecker, D.J., 2001. De novo initiation of viral RNA-dependent RNA synthesis. Virology 287, 251-260.

Kekarainen, T., Savilahti, H., Valkonen, J.P.T., 2002. Functional Genomics on Potato Virus A: Virus Genome-Wide Map of Sites Essential for Virus Propagation. Genome Res. 12, 584-594. 
Koonin, E.V., 1991. The phylogeny of RNA-dependent RNA polymerases of positivestrand RNA viruses. J. Gen. Virol. 72, 2197-2206.

Koonin, E.V., Dolja, V.V., 1993. Evolution and taxonomy of positive-strand RNA viruses: implications of comparative analysis of amino acid sequences. Critical Reviews in Biochemistry and Molecular Biology 28, 375-430.

Kwon, S.J., Kim, K.H., 2006. The SL1 stem-loop structure at the 5'-end of potato virus X RNA is required for efficient binding to host proteins and for viral infectivity. Mol. Cells 21, 63-75.

Lai, M.M.C., 1998. Cellular factors in the transcription and replication of viral RNA genomes: a parallel to DNA-dependent RNA transcription. Virology 244, 1-12.

Li, Y.I., Cheng, Y.M., Huang, Y.L., Tsai, C.H., Hsu, Y.H., Meng, M., 1998. Identification and characterization of the Escherichia coli-expressed RNA-dependent RNA polymerase of bamboo mosaic virus. J. Virol. 72 (12), 10093-10099.

Li, Y.I., Chen, Y.J., Hsu, Y.H., Meng, M., 2001a. Characterization of the AdoMetdependent guanylyltransferase activity that is associated with the $\mathrm{N}$ terminus of bamboo mosaic virus replicase. J. Virol. 75(2), 782-788.

Li, Y.I., Shih, T.W., Hsu, Y.H., Han, Y.T., Huang, Y.L., Meng, M., 2001b. The helicaselike domain of plant Potexvirus replicase participates in formation of RNA 5' cap structure by exhibiting RNA 5'-triphosphatase activity. J. Virol. 75 (24), 1211412120.

Lin, J.-W., Chiu, H.-N., Chen, I.-H., Chen, T.-C., Hsu, Y.-H. \& Tsai, C.-H. 2005. Structural and functional analysis of the cis-acting elements required for plus-strand RNA synthesis of Bamboo mosaic virus. J Virol. 79, 9046-9053.

Liou, M.R., Chen, Y.R., Liou, R.F., 2004. Complete nucleotide sequence and genome organization of a Cactus virus $X$ strain from Hylocereus undatus (Cactaceae). Arch. Virol. 149, 1037-1043. 
Lohman, T.M., Bjornson, K. P., 1996. Mechanisms of helicase-catalyzed DNA unwinding. Annu. Rev. Biochem. 65, 169-214.

Longstaff, M., Brigneti, G., Boccard, F., Chapman, S., Baulcombe, D., 1993. Extreme resistance to potato virus $\mathrm{X}$ infection in plants expressing modified components of the putative viral replicase. EMBO J. 12, 379-386.

Lu, R., Malcuit, I., Moffett, P., Ruiz, M.T., Peart, J., Wu, A.J., Rathjen, J.P., Bendahmane, A., Day, L., Baulcombe, D.C., 2003. High throughput virus induced gene silencing implicates heat shock protein 90 in plant disease resistance. EMBO J. 22, 56905699.

Miller, E.D., Kim, K.H., Hemenway, C., 1999. Restoration of a stemloop structure required for potato virus $\mathrm{X}$ accumulation indicates selection for a mismatch and a GNRA tetraloop. Virology 260, 342-353.

Ng, K.K.S., Arnold, J.J., Cameron, C.E., 2008. Structure-Function Relationships Among RNA-Dependent RNA Polymerases. Curr. Top Microbil. Immunol. 320, 137-156.

O’Reilly, E.K., Kao, C.C., 1998. Analysis of RNA-dependent RNA polymerase structure and function as guided by known polymerase structures and computer predictions of secondary structure. Virology. 252, 287-303.

Petyuk, V., McDermott, J., Cook, M., Sauer, B., 2004. Fuctional Mapping of Cre recombinase by Pentapeptide Insertional Mutagenesis. J. Biol. Chemistry 279, 37040-37048.

Pillai-Nair, N., Kim, K.H., Hemenway, C., 2003. Cis-Acting regulatory elements in the potato virus X 39 non-translated region differentially affect minus-strand and plusstrand RNA accumulation. J. Mol. Biol. 326, 701-720.

Poch, O., Sauvaget, I., Delarue, M., Tordo, N., 1989. Identification of four conserved motifs among RNA-dependent polymerase encoding elements. EMBO J. 8, 38673874. 
Prasher, D.C., Eckenrode, V.K., Ward, W.W., Prendergast, F.G., Cormier, M.J., 1992. Primary structure of the Aequorea victoria green-fluorescent protein. Gene 111, 229-233.

Poussu, E., Vihinen, M., Paulin, M., Savilahti, H., 2004. Probing the $\alpha$ Complementing Domain of E. coli $\beta$-Galactosidase With Use of an Insertional Pentapeptide Mutagenesis Strategy Based on $\mathrm{Mu}$ In Vitro DNA Transposition. Proteins: Structure, Function, and Bioinformatics 54, 681-692.

Rozanov, M.N., Koonin, E.V., Gorbalenya, A.E., 1992. Conservation of the putative methyltransferase domain: a hallmark of the 'Sindbis-like' supergroup of positivestrand RNA viruses. J. Gen. Virol. 73, 2129-2134.

Sambrook, J., Fritsch, E.F., Maniatis, T., 1989. Molecular cloning: a laboratory manual. 2nd ed. Cold Spring Harbor Laboratory, Cold Spring Harbor, N.Y.

Sickmier, E.A., Kreuzer, K.N., White, S.W., 2004. The crystal structure of the UvsW helicase from bacteriophage T4. Structure (Cambridge) 12, 583-592.

Theis, K., Chen, P.J., Skorvaga, M., Van Houten, B., Kisker, C., 1999. Crystal structure of UvrB, a DNA helicase adapted for nucleotide excision repair. EMBO J. 18, 68996907.

Thompson, J.D., Gibson, T.J., Plewniak, F., Jeanmougin, F., Higgins, D.G., 1997. The CLUSTAL_X windows interface: flexible strategies for multiple sequence alignment aided by quality analysis tools. Nucleic Acids Res., 25, 4876-4882.

Van der Heijden, M.W., Bol, J.F., 2002. Composition of alphavirus-like replication complexes: involvement of virus and host encoded proteins. Arch. Virol. 147, 875898.

Van der Vlugt, R.A.A., Berendsen, M., 2002. Development of a general potexvirus detection method. European Journal of Plant Pathology 108, 367-371. 
Varrelmann, M., Maiss, E., Pilot, R., Palkovics, L., 2007. Use of pentapeptide-insertion scanning mutagenesis for functional mapping of the plum pox virus helper component proteinase suppressor of gene silencing. Virology 74, 7462-7469.

Verchot-Lubicz, J., Ye, C.M., Bamunusinghe, D., 2007. Molecular biology of potexviruses: recent advances. J. Gen. Virol. 88 (6), 1643-1655.

Vlot, A.C., Neeleman, L., Linthorst, H.J.M., Bol, J.F., 2001. Role of the 3 '-untranslated regions of alfalfa mosaic virus RNAs in the formation of a transiently expressed replicase in plants and in the assembly of virions. J. Virol. 75, 6440-6449.

Voinnet, O., Lederer, C., Baulcombe, D.C., 2000. A viral movement protein prevents spread of the gene silencing signal in Nicotiana benthamiana. Cell 103, 157-167.

Wu, J., Kumar Bera, A., Kuhn, R.J., Smith, J.L., 2005. Structure of the Flavivirus Helicase: Implications for Catalytic Activity, Protein Interactions, and Proteolytic Processing. J. Virol. 79, 10268-10277.

Yao, N., Hesson, T., Cable, M., Hong, Z., Kwong, A.D., Le, H.V., Weber, P.C., 1997. Structure of the hepatitis C virus RNA helicase domain. Nat. Struct. Biol. 4, 463467.

Yao, N., Reichert, P., Taremi, S.S., Prosise, W.W., Weber, P.C., 1999. Molecular views of viral polyprotein processing revealed by the crystal structure of the hepatitis $C$ virus bifunctional protease-helicase. Structure Fold Des. 7, 1353-1363.

Zhou, Y., Ray, D., Zhao, Y., Dong, H., Ren, S., Li, Z., Guo, Y., Bernard, A., Shi, P.Y., 2007. Structure and Function of Flavivrus NS5 Methyltransferase. J. Virol. 81(8), 3891-3903. 


\title{
Kapitel 3
}

\section{Evidence that the linker between methyltransferase and helicase domains of the potato virus $X$ replicase is involved in homologous RNA recombination*}

\author{
Heidrun-Katharina Draghici ${ }^{1}$, and Mark Varrelmann ${ }^{\mathrm{a},{ }}{ }_{\dagger}$ \\ ${ }^{a}$ Department of Crop Sciences, Section Plant Virology, University of Göttingen, \\ Grisebachstrasse 6, D-37077 Göttingen, Germany \\ ${ }^{b}$ Institute of Sugar Beet Research, Department of Phytopathology, Holtenser Landstr. 77, \\ D-37079 Göttingen, Germany \\ $\dagger$ Both authors contributed equally to this work.
}

\begin{abstract}
Recombination in RNA viruses, one of the main factors contributing to their genetic variability and evolution, is a widespread phenomenon. In this study, an in vivo assay to characterize RNA recombination in potato virus $\mathrm{X}$ (PVX) under high selection pressure was established. Agrobacterium tumefaciens was used to express in Nicotiana benthamiana leaf tissue both a PVX isolate labelled with green fluorescent protein (GFP) containing a coat protein deletion mutation $(\Delta \mathrm{CP})$ and a transcript encoding a functional coat protein $+3^{\prime}$-ntr. Co-expression of the constructs led to virus movement, systemic infection, and exactly reconstituted recombinants were observed in $69 \%$ of inoculated plants. Similar results were obtained using particle bombardment, demonstrating that recombination mediated by $A$. tumefaciens was not responsible for the phenomenon. The time of recombination could be estimated by agroinfection of two PVX mutants missing
\end{abstract}

\footnotetext{
*This paper is submitted for publication in Journal of Virology (JVI00179-08)
} 
the 3 '- and $5^{\prime}$-half of the genome, respectively, with an overlap in the triple gene block 1 gene, allowing GFP expression only in case of recombination. Ten different pentapeptide insertion scanning replicase mutants with replication abilities comparable to wild-type virus were applied in the different recombination assays. Two neighboring mutants affecting the linker between the methyltransferase and helicase domains were shown to be strongly debilitated in their ability to recombine. The possible functional separation of replication and recombination in the replicase molecule supports the model that RNA recombination represents a distinct function of this protein, although the underlying mechanism still needs to be investigated.

\section{INTRODUCTION}

RNA virus variability is mainly generated by mutation, reassortment (in case of viruses encoding a multipartite genome) and covalent rearrangements of recombination origin including duplications, deletions and insertions. Subsequent phenotypic selection results in adaptation to modified environmental conditions $(28,83)$. The mutation rate is high among RNA viruses and driven by infidelity of template replication due to missing proofreading ability of RNA-dependent RNA polymerases (RdRps) (29, 30). As recombination links two or more RNA molecules, it is believed to rescue viral genomes by repairing mutation errors and leading to enhanced viral fitness $(2,34,94)$. In concert with mutation, recombination represents the major source of evolutionary variation of plant virus populations $(42,43)$. RNA recombination in plant viruses is a widespread phenomenon detected in several plant virus groups and families (reviewed in 1, 5, 22). Experimental in vivo evidence has been found in several different virus species $(3,18,55$, $74,94)$. In general the approaches for recombination detection can be categorized by the selection pressure applied. One frequently used system is the generation of a defective virus mutant and a transgenic plant expressing the corresponding functional gene, thereby applying high selection pressure on the production of functionally reconstituted recombinants (i.e. 39, 67). Experimental setups designed to detect virus recombinants under natural conditions applying no apparent selection pressure often use virus mixed infections $(2,27)$. Several model systems have been established to increase the knowledge about the complex nature (functional parameters and mechanisms) of RNA recombination. These systems include plant-infecting viruses like brome mosaic virus (BMV) and cowpea chlorotic mottle virus (CCMV) (both genus Bromovirus) $(6,8,16,37)$, which are members 
of the supergroup III (alpha-like viruses, 63, reviewed in 89). Tomato bushy stunt virus (TBSV) (genus Tombusvirus) (79) and turnip crinkle virus (TCV) (genus Carmovirus) (19, 96) as well as RNA bacteriophage Qß (15) represent supergroup II (carmo-like viruses) virus model systems. Animal infecting model viruses are poliovirus (57) and mouse hepatitis virus $(10,38)$. These experimental systems together with in vitro recombination assays $(9,60,61$ reviewed in 46) have led to the establishment of the replicase-driven template-switching model. Replicative recombination is associated with synthesis of a complementary (nascent) strand, template switch from a donor to an acceptor RNA and use of the nascent strand as a primer to complete strand synthesis on the acceptor strand. Details about variants of nascent strand transfer are summarized in Gmyl and Agol (46) and Nagy and Simon (75). Several types of RNA structural elements (sequence homology, AU-rich motifs, complementarity, replicative cis elements and secondary structure) have been identified that induce and influence replicative recombination $(16,71,72,73,77,78$, 87). In contrast to the replicative models there is evidence for nonreplicative RNA recombination, possibly based on RNA breakage and ligation found in bacteriophage Q $\beta$ and polioviruses $(23,24,40,44,45)$.

Potato virus X (PVX) a member of the family Flexiviridae (4), genus Potexvirus as well has been described to perform RNA recombination. The virus under study is also a member of the supergroup III (alpha-like virus), with rod-shaped particle morphology, possessing a replicase protein with methyltransferase (MT), helicase (HEL) and Polymerase (POL) domain in a single molecule and thus differing compared to those encoded by the recombination model plant viruses described so far (i.e. 47, 51, 63, reviewed in 90). First reports showed that a PVX based plant expression vector containing duplicated subgenomic coat protein promoters ( $\mathrm{sgPr}$ ) displayed genomic instability and partial loss of the inserted sequence, assumed to occur by similarity-essential and -assisted recombination $(11,21,25)$. However, experimental evidence for the acquisition of sequences from transcripts of other parental origin is still lacking. Another support for the existence of recombination in Potexviruses comes from Defective RNA observation of bamboo mosaic virus, generated by internal deletions of the wild type virus with junction sites displaying significant sequence similarity (95) and from phylogenetic analysis of cymbidium mosaic virus (88).

The goal of this study was the development of an experimental system to efficiently study the RNA recombination of PVX. For the first time we used the system of agroinfection by intercellular leaf space infiltration for constitutive expression of a PVX 
coat protein mutant carrying a GFP marker and a functional CP transcript to study RNA recombination. Particle bombardment experiments were performed to exclude that agrobacterium-mediated DNA recombination might produce artifacts and promotorless PVX CP containing plasmids were applied to further exclude plant DNA recombination. Finally pentapeptide scanning mutagenesis of the replicase in viral background was used for selection of replication competent mutants which display strongly reduced recombination ability, to supply evidence that the viral replicase is not only responsible for but additionally possesses a functional domain for the process of RNA recombination.

\section{MATERIALS AND METHODS}

PVX. PVX-UK3 (type X, Group 3) (59, 85), was kindly supplied by Stefan Winter (Plant Virus Department, German Collection of Microorganisms and Cell Cultures, Braunschweig, Germany) and propagated on Nicotiana benthamiana plants.

Clones and infectious transcripts. If identity of clones had to be confirmed, DNA sequencing was performed by a commercial company (MWG Biotech AG, Martinsried, Germany). All recombinant plasmid manipulations were performed as described previously (84) unless otherwise specified. The Cauliflower mosaic virus (CaMV) 35Spromoter driven PVX plant expression plasmid cloned in a binary vector for agroinfection (pGr106) (58, 68, GenBank accession no. AY297843) used in this study was obtained from David Baulcombe (Sainsbury Laboratory, Norwich, UK). It contains the PVX plant expression vector (21) constructed from cDNA of PVX strain UK3. In order to express GFP10 (81) from pGr106, the $g f p$ open reading frame (ORF) was excised from pPVX204 (12) using ClaI and SalI and cloned into pGr106. The resulting clone was named 35SPVX-GFP (Fig. 1A).

35S-PVX-GFP derived mutants. To construct a movement-defective 35S-PVXGFP CP-deletion mutant, a $\Delta 514-646$ nucleotide (nt) deletion was introduced into the CP consisting entirely of $237 \mathrm{aa} / 711 \mathrm{nt}$, leading to a $\Delta 173-215$ amino acid (aa) deletion. This was achieved by subcloning a single-site (SalI and SpeI) PVX CP and 3'-nontranslated region (3'-ntr) fragment from 35S-PVX-GFP and subsequently removing a CP-gene fragment (nt 514-646 in the CP ORF) between two PvuII restriction sites, followed by 
backcloning and sequence verification. The resulting plasmid was named 35S-PVX-GFP- $\triangle$ CP (Fig. 1A).

Ten different replicase pentapeptide scanning (PS) mutants in viral background with an insertion in the methyltransferase and linker region between methyltransferase and helicase domain carrying the $\mathrm{CP}$ deletion with replication abilities comparable to $35 \mathrm{~S}$ PVX-GFP- $\triangle$ CP (35S-PVX-GFP- $\triangle$ CP-PSM-254, -430, -434, -488, -513, -574, -576, -592, 593 and -595 , numbers in accordance to PVX replicase amino acid sequence) were described previously (31).

To construct two 35S-PVX-GFP deletion mutants overlapping in the triple gene block 1 gene (TGB1) the following cloning steps were performed. To delete the complete 3'-end (nt 6149-7435) from pGr106 (encompasses TGB2 and 3, CP and 3'-ntr), an NdeI-XhoI-fragment was excised followed by Klenow fill-in and religation. The resulting clone was named 35S-PVX-RdRp-TGB1. To produce a 35S driven clone expressing transcripts of the $3^{\prime}$ - half of the PVX genome (TGB1-3, GFP, CP and $3^{\prime}$-ntr) nt 5488-8286 were PCR amplified with the following primers: TGB1-up (5'-TTAGAGCTCATGGATATTCTCATCAGTAGTT-3') and poly-T-low (5'-CGGGGATCCCTCGAGAAGCTTTTTTTTTTTTTTTTT-3') (restriction sites in primers underlined and virus specific sequences in italics). The PCR-fragment was SacI-BamHI-cloned in binary vector pBIN61S (86) and named 35S-TGB1-3-GFP-CP-3'ntr. Both PVX deletion mutants (Fig. 1C) were electroporated into A. tumefaciens (pGr106 derived plasmids together with pSoup) and used in $N$. benthamiana leaves for the recombination assay. pSoup represents a helper plasmid for pGreen based binary vectors, supporting replication functions in trans (53). 


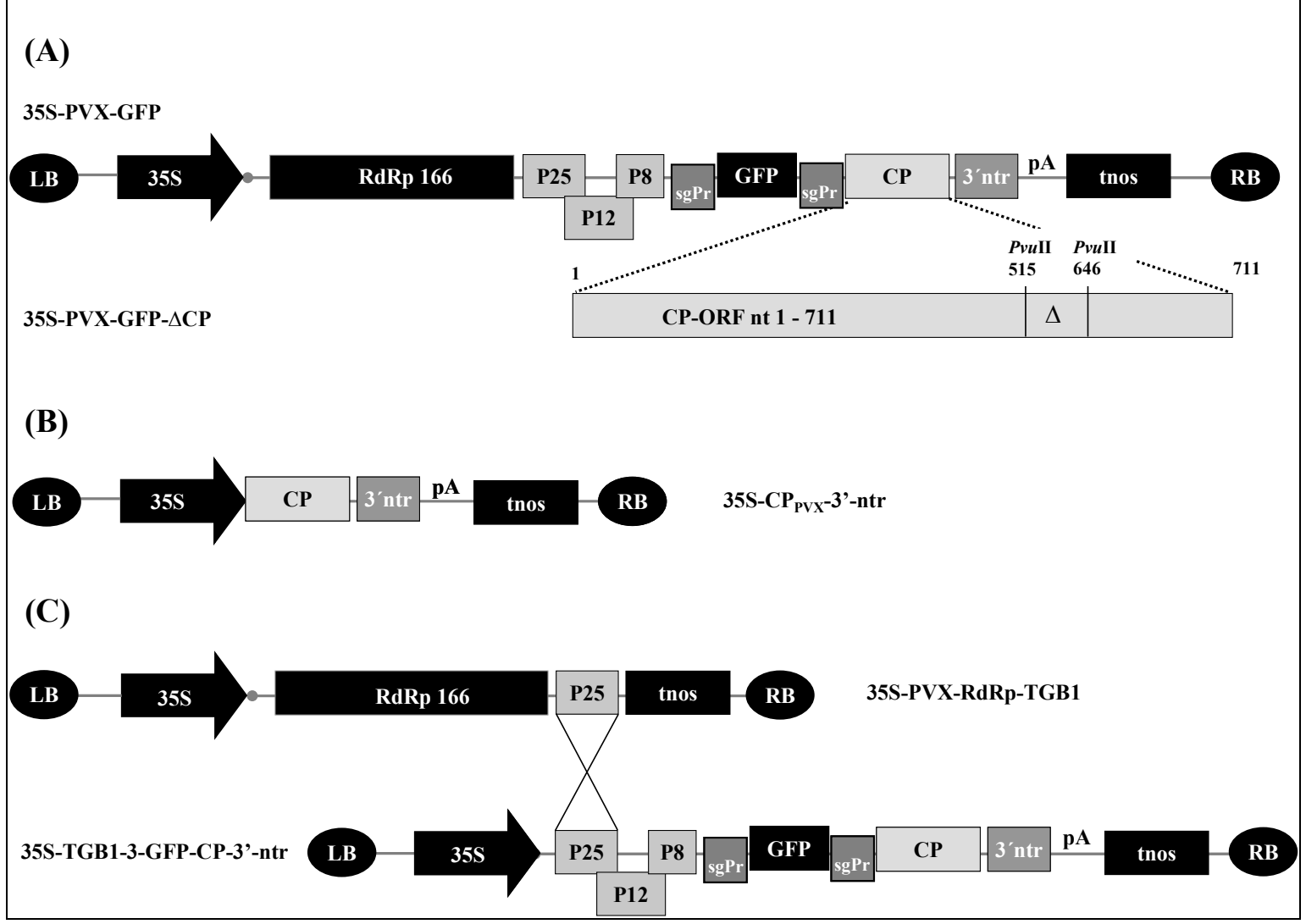

Fig. 1. 35S-PVX-GFP deletion mutants. (A) Schematic representation of 35S-PVX-GFP and restriction sites in the CP-gene used for the generation of 35S-PVX-GFP- $\triangle \mathrm{CP}$ (not drawn to scale): LB and RB, left and right T-DNA border sequences; 35S, 35S promoter of cauliflower mosaic virus; RdRp, 166K, RNAdependent RNA polymerase ORF; 25K, $8 \mathrm{~K}$ and $12 \mathrm{~K}$, triple gene block ORFs (TGB); sgPr, subgenomic CP promoter; GFP, green fluorescent protein ORF; CP, coat protein ORF; 3'-ntr, 3'-nontranslated region; pA, CaMV poly(A) terminator; tnos, nopaline synthase terminator. The complete PVX CP-ORF includes 711 bp and is illustrated as a light grey box. (B) Diagram of $35 \mathrm{~S}-\mathrm{CP}_{\mathrm{PVX}^{-}} 3^{\prime}$-ntr containing the intact PVX CP-gene including the PVX 3'-ntr under control of the $35 \mathrm{~S}$ and tnos between LB and RB of a binary vector. (C) $35 \mathrm{~S}$ PVX-RdRp-TGB1 deletion mutant containing RdRp and TGB1 ORFs under control of $35 \mathrm{~S}$ and tnos. The deletion mutant 35S-TGB1-3-GFP-CP-3'-ntr contains TGB1-3, GFP and CP ORFs.

Construction of binary vectors, expressing in vivo transcripts the complete PVX CP-gene and $3^{\prime}$-ntr. The exact PVX-CP ORF and complete 3 '-ntr region was RT-PCR-amplified from total RNA extracts (RNeasy, Qiagen) of virus infected $N$. benthamiana leaf tissue introducing flanking SacI and BamHI restriction sites. The following primers were used: CP-up (5'-TTAGAGCTCACCATGTCAGCACC $A G C T A G C A C-3$ ') and poly-T-low. The PCR fragments were SacI-BamHI-cloned in a binary vector pBIN61S under control of the enhanced CaMV 35S-promotor and polyA-terminator (86), sequence verified and named 35S-CP $\mathrm{PVX}^{-}{ }^{\prime}$ '-ntr (FIG. 1B). 
Cloning and sequencing of CP-gene and 3 '-ntr from recombinant PVX isolates. Upper leaves of $N$. benthamiana plants used in the (PVX) recombination assay, displaying systemic infection as monitored by GFP-fluorescence were used for total RNA extraction and RT-PCR amplification of PVX CP-gene and 3'-ntr using primers: PVX-GFP-up (5'-ATGTCGACCCCTGTCCTTTTACCAGACA-3') and poly-T-low. PCR-fragments were either directly sequenced or SalI-BamHI cloned into pBluescriptII (SK-) (Stratagene) and the sequence determined.

Recombination assay. All binary vectors were transformed into A. tumefaciens LBA4404 (54) using electroporation. 35S-PVX-GFP and 35S-PVX-GFP- $\Delta C P$, both based on pGreen backbone, were co-electroporated with pSoup. A. tumefaciens infiltration was carried out according to Voinnet et al. (93) with $\mathrm{OD}_{600}=0.1$, using 4-week old $1.5 \mathrm{~cm}$ in diameter N. benthamiana leaf patches. To produce 35S-PVX-GFP with recombinant CPgene, 35S-PVX-GFP- $\triangle \mathrm{CP}$ was co-infiltrated with $35 \mathrm{~S}-\mathrm{CP}_{\mathrm{PVX}}-3$ '-ntr. Agroinfiltrated leaf patches were examined under fluorescence microscopy (FM). Veins of co-infiltrated patches were monitored for GFP fluorescence with a hand-held long wave UV-lamp (Black Ray model B 100 AP, 100W, UV products), to visualize occurrence and movement of recombinant PVX-GFP. Photographs were taken using a digital camera (Nikon D50).

Particle bombardment. Approximately $100 \mathrm{ng}$ of column-purified (Qiagen) plasmid DNA of $35 \mathrm{~S}-\mathrm{PVX}-\mathrm{GFP}-\triangle \mathrm{CP}$ and intact $35 \mathrm{~S}-\mathrm{CP}_{\mathrm{PVX}}-3$ '-ntr, respectively, or a mixture of the two plasmids was used for microprojectile bombardment on mature detached leafs of 4 to 5 week-old $N$. benthamiana plants, using a particle inflow gun (50). Furthermore a promotorless and double- (sense and antisense) terminated CP-gene construct, named 35S-CP-no-transcripts was used for co-bombardment with 35S-PVX-GFP- $\triangle$ CP on 15 detached $N$. benthamiana leaves.

Construction of a binary vector expressing untranscribable PVX-CP. In order to transform $N$. benthamiana parenchyma leaf cells with $35 \mathrm{~S}-\mathrm{CP}_{\mathrm{PVX}}-3$ '-ntr coding sequence but to exclude the generation of sense transcripts, the $35 \mathrm{~S}-\mathrm{CP}_{\mathrm{PVX}}-3^{\prime}-$ ntr binary vector was modified. A pA-CaMV signal was introduced (Ecl136II-EcoRV) into the Ecl136II-restriction site 5' to the CP coding sequence and the $35 \mathrm{~S}$ promoter was removed by an AseI-Ecl136II fill-in religation. The generation of antisense (as) transcripts from plants genomic promoters in as-orientation was inhibited by the insertion of the PCR- 
amplified nopaline synthase terminator sequence (tnos) in as-orientation into the EcoRIsite downstream to the polyA-terminator. The resulting clone was named 35S-CP-notranscripts.

Epifluorescence microscopy (FM). Agroinfiltrated or particle bombarded $N$. benthamiana leaf patches were monitored for GFP fluorescence using epifluorescence microscopy (Leica DMR) supplied with GFP filter (Sapph-GFP) in order to visualize PVX-expressed GFP-fluorescence. Photographs were taken using Leica DFC camera, DFC300 FX.

Insertion of PVX replicase PS-mutants into 35S-PVX-GFP and 35S-PVX-RdRp-TGB1. A part of the replicase gene, containing the mutation together with the partial triple gene block 1 ORF was removed from the two PVX PS-mutants 35SPVX-GFP- $\triangle$ CP-PSM-430 and -PSM-434 using restriction sites BamHI plus Bsp120I and cloned into 35S-PVX-GFP and 35S-PVX-RdRp-TGB1 respectively. The resulting 35SPVX-GFP and 35S-PVX-RdRp-TGB1 clones were named -PSM-430 and -PSM-434 respectively.

\section{RESULTS}

A movement defective PVX CP-deletion mutant is reconstituted with high abundance by recombination with an intact CP-transcript. In order to establish an experimental system to efficiently analyze PVX recombination under high selection pressure, a movement defective PVX mutant was analyzed for its ability to recombine with transiently expressed PVX-CP +3 '-ntr transcripts. For constitutive expression of both the mutant viral genome and CP-transcripts, the method of transient agrobacterium-mediated expression by leaf infiltration was chosen. 35S-PVX-GFP was used for the construction of a $\Delta 515-646 \mathrm{nt}$ deletion mutation in the $711 \mathrm{bp} \mathrm{CP-gene,} \mathrm{named} \mathrm{35S-PVX-GFP-} \Delta \mathrm{CP}$ (Fig. 1A). As the CP of PVX is indispensable for virus movement (85), the deletion completely abolished short- and long-distance movement in N. benthamiana leaves. In contrast to PVX-GFP, which expresses GFP in the whole plant, PVX-GFP- $\triangle \mathrm{CP}$ expressed GFP fluorescence was limited to the agroinfiltrated leaf patches (Fig. 2B). To offer an intact CP-transcript as a template for viral RNA-recombination, the entire PVX CP-gene plus 3'ntr was placed under control of $35 \mathrm{~S}$ in a binary vector for the generation of in vivo 
transcripts in co-expression with $35 \mathrm{~S}-\mathrm{PVX}-\mathrm{GFP}-\Delta \mathrm{CP}$ in $N$. benthamiana leaf patches. The overlapping homologous region encompassed the entire $3^{\prime}$-ntr, 65 bp of the CP-gene $3^{\prime}-$ end and 514 bp 5' upstream of the deletion.

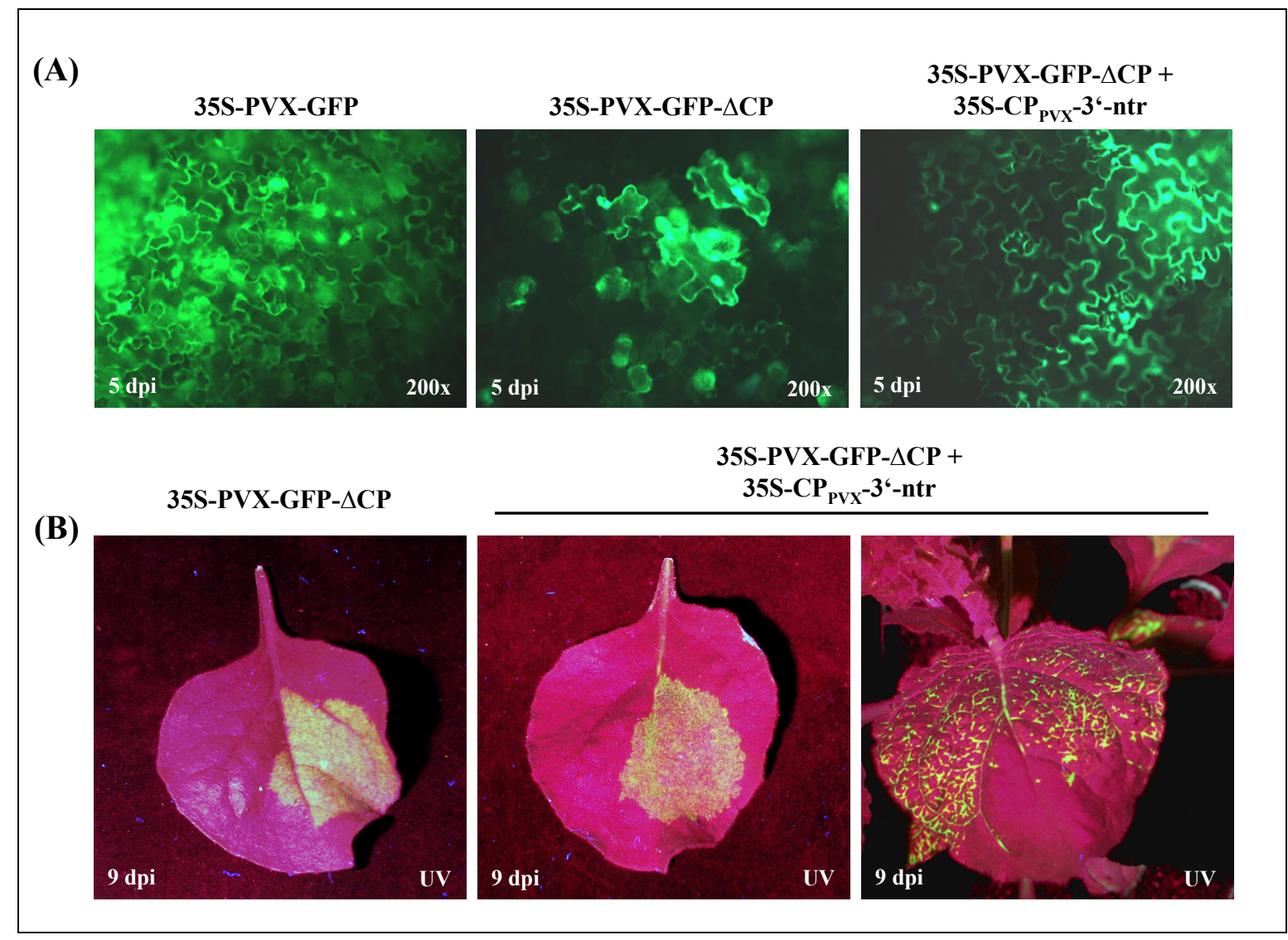

Fig. 2. Complementation and recombination of agroinfected movement-defective PVX with agroexpressed in vivo transcripts of PVX coat protein gene. (A) FM photographs of the leaf area at 5 dpi documented with a GFP-filter and 200-fold magnification and infiltrated with 35S-PVX-GFP, 35S-PVX-GFP- $\Delta$ CP and 35SPVX-GFP- $\triangle \mathrm{CP}+35 \mathrm{~S}-\mathrm{CP}_{\mathrm{PVX}}-3^{\prime}$ '-ntr respectively. (B left) Agroinfiltrated $N$. benthamiana leaves at 9 dpi following infiltration with 35S-PVX-GFP- $\triangle \mathrm{CP}$ displayed GFP fluorescence under UV-light, which was limited to the agroinfiltrated leaf patch. (B middle) leaves infiltrated with $35 \mathrm{~S}-\mathrm{PVX}-\mathrm{GFP}-\Delta \mathrm{CP}+35 \mathrm{~S}-\mathrm{CP}_{\mathrm{PVX}}{ }^{-}$ 3'-ntr showed spreading PVX-expressed GFP-fluorescence, which finally reached the upper non-infiltrated leaves (B right).

$N$. benthamiana leaf tissue infiltrated with $35 \mathrm{~S}-\mathrm{PVX}-\mathrm{GFP}-\triangle \mathrm{CP}$ alone and in combination with $35 \mathrm{~S}-\mathrm{CP}_{\mathrm{PVX}}-3^{\prime}$ 'ntr was monitored under FM at 5 dpi and UV at 9 dpi (Fig. 2A). Mixed infiltrated patches displayed much stronger fluorescence, which was confirmed under FM examination as higher number of fluorescing cells, indicative for complementation and/or recombination of the 35S-PVX-GFP cell-to-cell movement defect 
by the 35S-expressed intact CP or CP RNA. To access the ability of PVX to recombine with the co-expressed transcript with an intact CP-gene and to produce wt PVX able to move out of the infiltrated patch, a total of $65 \mathrm{~N}$. benthamiana plants were used for coinfiltration (four patches each) with 35S-PVX-GFP- $\triangle \mathrm{CP}$ and $35 \mathrm{~S}_{-} \mathrm{CP}_{\mathrm{PVX}}-3$ '-ntr (Fig. 2B). Starting at 9 dpi, leaf-veins connected to the infiltrated patches displayed spreading PVXexpressed GFP-fluorescence, which reached the upper non-infiltrated leaves a few days later. At 14 dpi 60/65 inoculated plants displayed systemic PVX-GFP infection. In contrast in none of the 50 plants treated only with $35 \mathrm{~S}-\mathrm{PVX}-\mathrm{GFP}-\triangle \mathrm{CP}$ (infiltrated with a total of 200 patches), virus movement was observed and GFP-fluorescence remained restricted to the leaf-patches. Upper non-inoculated leaves of five independent plants containing PVXGFP recombinants were taken for cloning and sequencing of the recombinant CP-gene. RT-PCR amplification with upper primer homologous to the PVX-encoded GFP-ORF (PVX-rec-CP-up) excluded amplification of $35 \mathrm{~S}-\mathrm{CP}_{\mathrm{PVX}-3} 3^{\prime}-\mathrm{ntr}$ derived transcripts. Sequencing showed that wild-type CP-sequence was exactly reconstituted in all cases of the PVX-GFP recombinants (data not shown). The observation of systemic movement together with detection of a reconstituted intact $\mathrm{CP}$ encoding sequence demonstrated that complementation was not involved in this phenotype.

\section{Agrobacterium tumefaciens mediated DNA recombination is not responsible}

for the observed PVX recombination in the assay. A. tumefaciens possess the ability to integrate the T-DNA in its host genomes by homologous and non-homologous (illegitimate) recombination (for a recent review see 89). In order to exclude A. tumefaciens mediated DNA recombination as the cause for the observed recombination events, particle bombardment was used for delivery of $35 \mathrm{~S}-\mathrm{PVX}-\mathrm{GFP}-\Delta \mathrm{CP}$ and $35 \mathrm{~S}-$

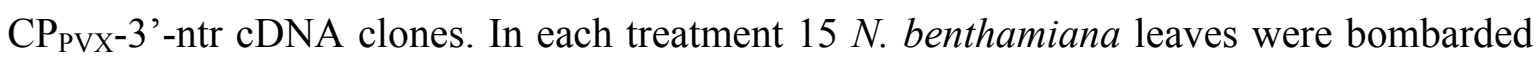
with $35 \mathrm{~S}-\mathrm{PVX}-\triangle \mathrm{CP}$ alone and in combination with $35 \mathrm{~S}-\mathrm{CP}_{\mathrm{PVX}}-3$ '-ntr. At 4 dpi treated leaves were examined under FM (Fig. 3). Bombardment with $35 \mathrm{~S}-\mathrm{PVX}-\Delta \mathrm{CP}$ plus $35 \mathrm{~S}-$

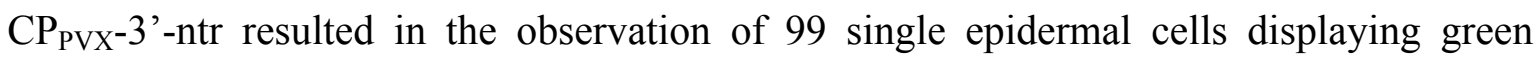
fluorescence indicative for PVX replication and its inability to leave the initially infected cell. PVX movement after CP-reconstitution by means of recombination was observed in 46 fluorescing patches with an average diameter of $425 \mu \mathrm{m}$ consisting of a multitude of cells. Bombardment with 35S-PVX-GFP- $\triangle \mathrm{CP}$ showed 73 single fluorescent cells but no PVX movement was observed. However the possibility remained that the recombination observed was not due to viral (RdRp-driven) RNA recombination but caused by the plants 
own genome repair DNA recombination machinery (82). In order to exclude or at least minimize the amount of transcripts produced from the integrated $35 \mathrm{~S}-\mathrm{CP}_{\mathrm{PVX}}-3$ '-ntr containing T-DNA, a promotorless and double- (sense and antisense) terminated CP-gene construct named 35S-CP-no-transcripts was generated and used for co-bombardment with 35S-PVX-GFP- $\triangle \mathrm{CP}$ on 15 detached $N$. benthamiana leaves. FM observation revealed 75 single fluorescing cells but no recombination event represented by virus movement was observed.

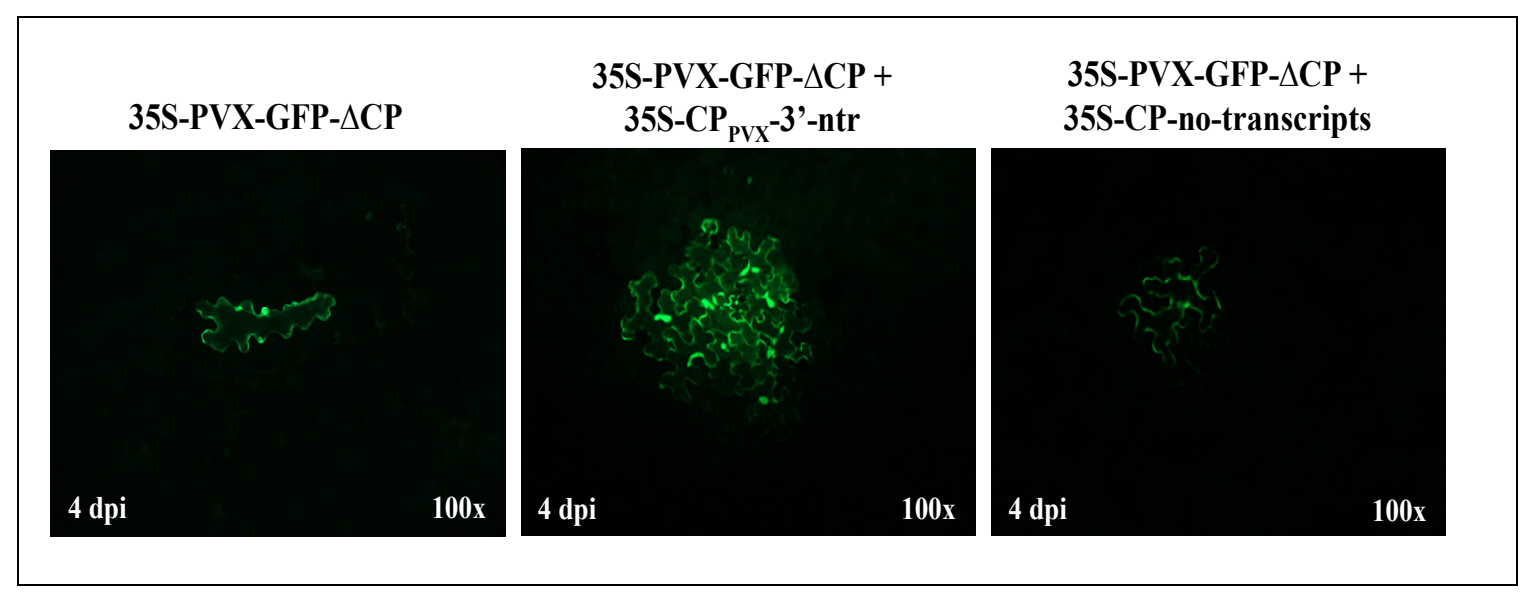

Fig. 3. PVX CP-gene reconstitution by means of recombination is observed after particle bombardment mediated transient expression of $35 \mathrm{~S}-\mathrm{PVX}-\mathrm{GFP}-\triangle \mathrm{CP}$ and $35 \mathrm{~S}-\mathrm{CP}_{\mathrm{PVX}}-3$ '-ntr transcripts. FM images of $N$. benthamiana leaf areas bombarded with PVX CP-deletion mutant 35S-PVX-GFP- $\Delta$ CP alone and in combination with $35 \mathrm{~S}-\mathrm{CP}_{\mathrm{PVX}}-3$ '-ntr and 35S-CP-no-transcripts respectively at 4 dpi.

Occurence of PVX-recombination can be visualized at single cell level. Using particle bombardment the recombination events were observed to occur around 4 dpi, which is faster than in agrobacterium leaf infiltration assay, where the recombination could be earliest detected, when recombinant PVX movement out of the infiltrated area was observed ( 8 dpi) because $35 \mathrm{~S}-\mathrm{PVX}-\mathrm{GFP}-\triangle \mathrm{CP}$ can autoreplicate and express GFP in the patch. To estimate the time-period until occurrence of PVX recombinants in the agroinfiltrated $N$. benthamiana leaf patch more precisely, two PVX deletion mutants missing the 3'- and 5'-half of the genome respectively and possessing an overlap of $661 \mathrm{bp}$ (representing nearly the entire TGB1 gene) were produced (Fig. 1B). 35S-PVX-RdRpTGB1 should allow the production of a primary transcript and expression of the PVXRdRp. Only if the RdRp would initiate synthesis of the viral minus strand on $(+)$ sense transcripts of 35S-TGB1-3-GFP-CP-3'-ntr, recombination in the TGB1 region may allow reconstitution of PVX-GFP and occurring GFP fluorescence should indicate recombination 
at single cell level. 35S-PVX-RdRp-TGB1 and 35S-TGB1-3-GFP-CP-3'-ntr respectively alone and in combination were agroinfiltrated to $N$. benthamiana leaf tissue ( 5 plants, 4 patches each). Only when co-infiltrated, several single cells displaying GFP-fluorescence were observed under FM already at 3 dpi in the infiltrated leaf patch, showing the occurrence of recombination events, which had reconstituted PVX-GFP (Fig. 4). At 4 and 5 dpi PVX-GFP movement occurred, leading to GFP-fluorescence in several cells. At 6 dpi plants co-agroinfiltrated with both constructs displayed GFP-fluorescence and virus symptoms in 20 out of 20 infiltrated leaf patches. In contrast no fluorescence and virus movement was detected when both deletion constructs were infiltrated alone. Because of the high number of GFP-fluorescent spots representing independent recombination events in one agroinfiltrated patch, the recombination frequency of recombinants events could not be evaluated in detail.

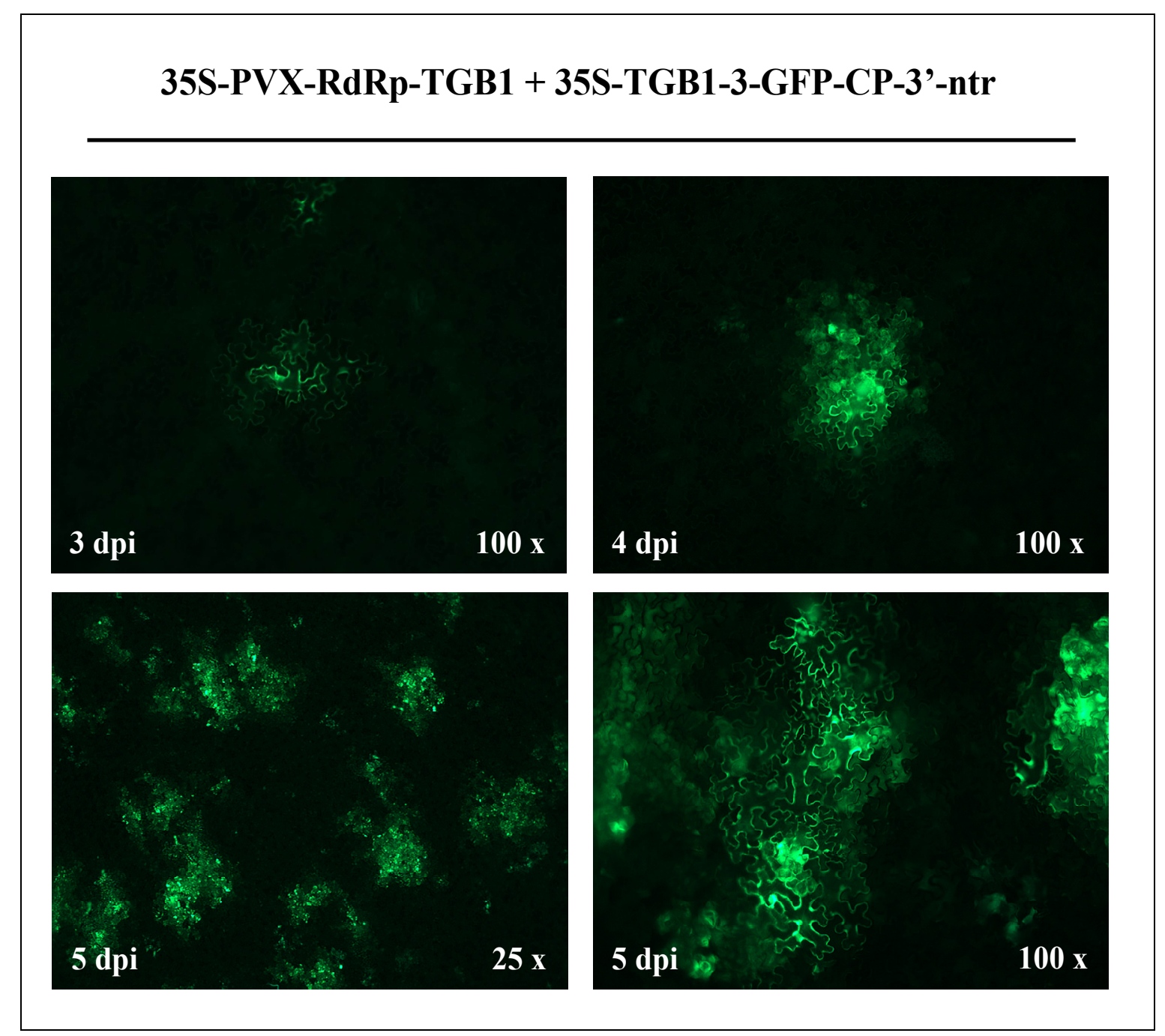

Fig. 4. Time-point of PVX recombination in agroinfiltrated $N$. benthamiana leaf patches applying two PVX deletion mutants. FM time-series images of $N$. benthamiana parenchyma cells, transiently expressing $35 \mathrm{~S}-$ 
PVX-RdRp-TGB1 and 35S-TGB1-3-GFP-CP-3'-ntr. Starting at 3 dpi GFP-fluorescence was displayed in a few cells. At 4 and 5 dpi PVX-GFP movement, leading to fluorescence in several cells, was observed.

\section{Identification of two adjacent PVX replicase PS-mutants, which display wild-} type like genome amplification abilities but are impaired in their property to recombine. In our previous study PS mutagenesis of the PVX replicase ORF identified 10 mutants in 35S-PVX-GFP- $\triangle$ CP background (35S-PVX-GFP- $\triangle$ CP-PSM-254, -430, -434, $-488,-513,-574,-576,-592,-593$ and -595 , numbers in accordance to pentapeptide insertion position in the PVX replicase) which displayed genome amplification abilities similar to non-mutated PVX-GFP- $\triangle \mathrm{CP}$ when used for agroinfection in $N$. benthamiana leaf patches (31). All except one (-PSM-254) of the 10 replicase mutants, displayed pentapeptide insertions in a linker region between methyltransferase and helicase domain. All the remaining 44 PS-mutants randomly spread over the protein completely abolished virus replication. To verify if one of the replication active mutants was possibly affected in its ability to recombine, all 10 where applied in the recombination assay together with 35S-CP $\mathrm{PVX}$-3'-ntr. Each mutant was used for co-infiltration of eight $N$. benthamiana leaf patches. All PS-mutants except the two neighboring replicase linker region mutants 35 S-PVX-GFP- $\triangle$ CP-PSM-430 and -434 recombined at an observed frequency comparable to $35 \mathrm{~S}-\mathrm{PVX}$-GFP- $\triangle \mathrm{CP}$. In all treatments seven-eight out of eight patches displayed virus movement (data not shown). Therefore the recombination assay with both selected mutants (PSM-430 and -434) was repeated with a higher number of infiltrated patches (Table 1). In order to demonstrate, that the pentapeptide insertion at aa position 430 and 434 respectively did not strongly interfere with genome amplification and systemic spread in $N$. benthamiana, what might interfere with the results of the recombination assay, both mutations were each inserted into 35S-PVX-GFP leading to 35S-PVX-GFP-PS430 and -PS434 respectively. Both mutants and 35S-PVX-GFP were agroinfiltrated each into 62 small leaf patches $(0.5 \mathrm{~cm}$ in diameter) in 4 week old $N$. benthamiana plants and the time was monitored until the virus had reached the primary leaf veins. Applying the wild-type, at 10 dpi PVX-GFP from all 62 patches had reached the veins. Both PVX-GFP-PS430 and -PS434 from all 62 patches reached the veins two days later, demonstrating that the pentapeptide insertion at the two neighboring positions did only marginally delay genome amplification and systemic spread in N. benthamiana compared to agroinfected PVX-GFP. 
Table 1.

Influence of two PVX replicase pentapeptide scanning mutations in the linker region between methyltransferase and helicase domain on the abundance of observed virus recombinants in the Agrobacterium-mediated recombination assay.

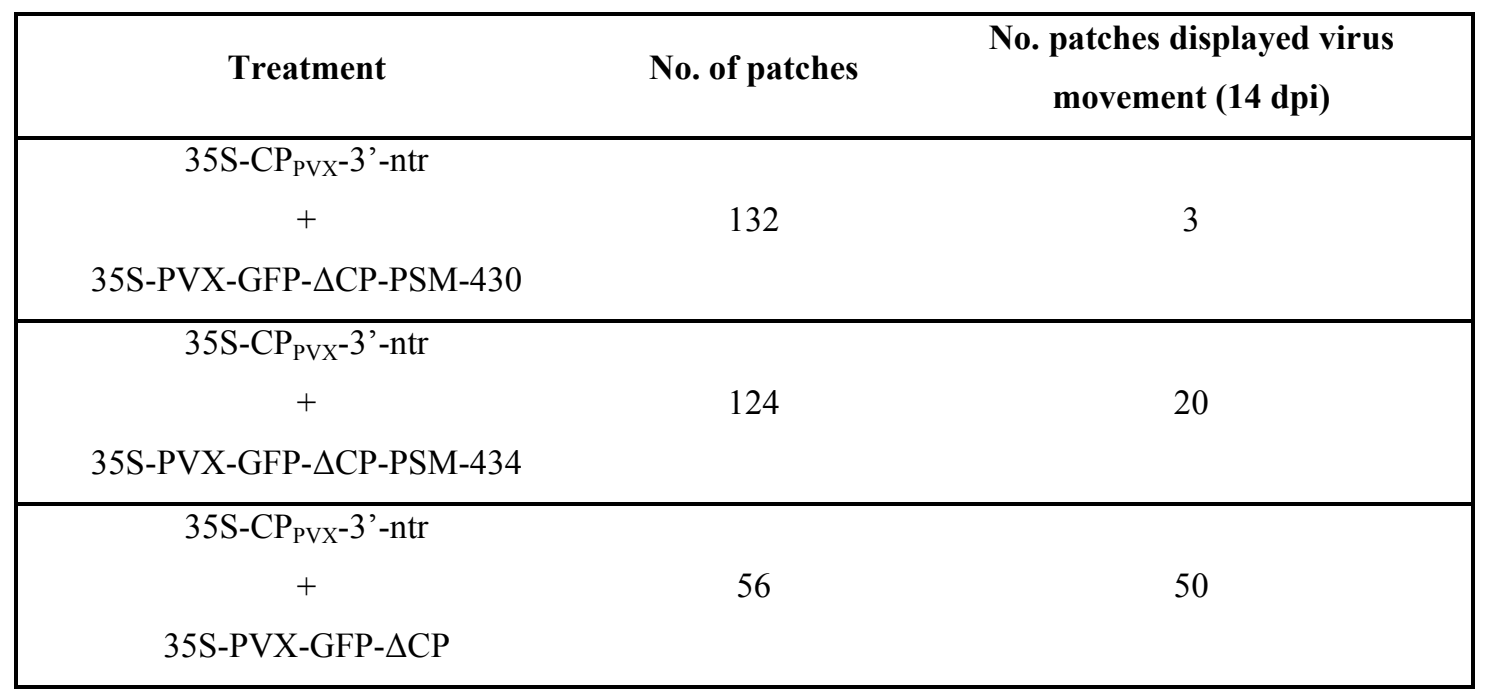

Evidence that the impaired ability to recombine is assay-independent. To show that the impaired recombination ability of PVX replicase PS-mutants 430 and 434 was independent of the assay, both mutations were introduced into 35S-PVX-RdRp-TGB1 and applied in the second above described recombination assay. $N$. benthamiana leaf tissue was infiltrated with the three combinations 35S-TGB1-3-GFP-CP-3'-ntr plus 35S-PVX-RdRp-TGB1, -PS430 and -PS434, respectively and the occurrence of GFP fluorescence was monitored under FM at 3, 4 and 5 dpi. Only when the unmodified 35S-PVX-RdRp-TGB1 was applied, single cells displaying GFP fluorescence were initially observed at $3 \mathrm{dpi}$ and visible PVX-GFP movement occurred at 4 to 5 dpi. To see, if recombination occurs less frequently and later than with the unmodified replicase, 23 $N$. benthamiana plants (4 patches each) were treated with the three combinations. Patches were monitored until $12 \mathrm{dpi}$ for the occurrence of recombinant PVX-GFP movement. All 20 patches of the control displayed PVX-GFP movement already at 7 dpi whereas even at 12 dpi only 2/92 and 40/92 patches in the case of 35S-PVX-RdRp-TGB1-PS430 and PS434 respectively showed spreading fluorescence, indicative for recombination. 


\section{DISCUSSION}

In the experimental system described here, we have developed an in vivo assay for the characterization of the PVX RNA recombination. The assay is based on Agrobacterium-mediated or particle bombardment delivered transient expression of two different parental viral transcripts for RNA recombination.

We adopted in our experimental system an approach consisting of two PVXderived transcripts, a PVX CP-deletion mutant and the corresponding intact gene, exerting strong selection pressure on the reconstitution of a movement competent PVX by means of recombination with high probability. The principle has already been applied in numerous viral systems to give a general proof of recombination $(3,7,8,13,14,17,19,34,39,41$, 48, 56, 67, 69, 91, 92). Compared to stable expression in transgenic plants, particle bombardment or mechanical transcript inoculation of two defective virus cDNA clones or pseudorecombinant viruses, however, agroinfection is more versatile. It allows testing of several different mutant constructs in shorter time periods and the parallel expression in higher number of cells in delimited tissue and therefore will facilitate the detection of less probably occurring recombinants.

Evaluation of the assay. A CP movement defect was applied as selective pressure for the reconstitution of a functional viral genome and the transient expression of an intact viral CP in the patch allowed complementation of the CP-defective PVX mutant. However, beyond the infiltrated patch, only recombinant virus was able to move. By transient agrobacterium-mediated 35S-driven expression the integration of the T-DNA into the plant genome leads mainly to the expression of virus sense transcripts available for recombination, however the production of antisense transcripts from genomic promoters in antisense orientation cannot be excluded. The PVX CP $(+)$ strand transcript produced from $35 \mathrm{~S}-\mathrm{CP}_{\mathrm{PVX}}-3$ '-ntr as well as the viral $(+)$ strand both allow minus (-) strand production, however in case of the CP (-) strand transcript, initiation of $(+)$ strand synthesis by the replicase is impossible, as the $5^{\prime}$-ntr is lacking (70). This suggests that the recombination events observed here have mainly occurred during (-) strand synthesis although recombination during $(+)$ strand synthesis cannot be excluded but is less likely. Particle bombardment control experiments excluded the effect of A.tumefaciens DNA recombination. Applying a promotorless and double-terminated CP-gene instead of in vivo transcripts, we suppressed the occurrence of intact PVX recombinants in our assay, 
demonstrating that most likely RNA recombination and not DNA recombination by the plants genome repair machinery was responsible for the observed effect.

Features of the system. Agroinfiltration as well as particle bombardment showed that the reconstitution of a functional PVX CP-gene was frequently observed independent of the assay. Comparing this to previous studies where moderate to strong selection pressure was applied but instead two defective virus cDNA clones were used or the intact gene was expressed in transgenic plants $(3,14,34,41,48,49,56,71,92)$ no remarkable difference was found. In comparison to previous systems, the use of PVX expressing a fluorescent marker gene allows for the first time to study factors influencing the in vivo occurrence of recombination more exact. Moreover it will allow the differentiation of independent recombinants in their ability to move and spread in the host plant. Separating the viral full-length clone into 3'- and 5'-terminal half with TGB1 ORF overlap enabled the precise monitoring of the time at which GFP fluorescence appeared in the infiltrated leaf space. This feature may be useful in further experiments to study the influence of environmental conditions on the frequency of recombination occurrence as suggested by Duggal and Wimmer (32). The extreme high recombination frequent observation of virus recombinations was remarkable, compared to the $\mathrm{CP}$-deletion recombination assay. This can only be explained by the fact that both mutants were unable to replicate autonomously and that the RdRp encoded by 35S-PVX-RdRp-TGB1 could only initiate viral (-) strand synthesis on 35S-TGB1-3-GFP-CP-3'-ntr. Therefore a much stronger selection pressure was applied in comparison to the PVX CP-deletion mutant recombination assay in which the movement defective virus was still able to autoreplicate. Both constructs (CP-deletion and TGB-overlap) forced the generation of recombinants high selection pressure. In principle the generation of mutations in PVX encoded genes which only slightly restrict a protein function and exerts lower selection pressure is conceivable.

\section{Involvement of a distinct PVX replicase region in RNA recombination.} Although application of double-terminated PVX CP containing plasmids without promoter sequences did not result in occurrence and detection of recombinants, DNA recombination and RNA recombination by host proteins like RNA polymerase II could not be entirely excluded. We were able to select two replicase mutants containing close neighboring pentapeptide insertions with nearly wild-type genome amplification abilities from a PSM library, leading to strongly reduced frequent occurrence of recombination events in two 
different assays. This finding supplied the final proof that functional reconstitution of the PVX CP-movement defect was caused by RNA recombination and that the viral replicase was responsible for the effect. To our knowledge, this work together with our previous study (31) represents the first systematic analysis of a plant virus replicase replication and recombination function in planta which resulted in separation of both functions. It can be anticipated that the functional domains MT, HEL and POL have to act together in one single protein to form a functional virus replicase, although the distinct biochemical activities of each separated domain was demonstrated for bamboo mosaic virus replicase in vitro $(52,62,64,65,66)$. The N-terminal MT and C-terminal HEL-POL containing parts of the potexvirus replicase are connected by a hyper-variable hydrophilic linker region encoded by approximately $100 \mathrm{bp}$. Interestingly, mainly this region tolerated pentapeptide insertions in relation to its genome amplification ability (31) and among those nine mutants, two neighboring mutants were strongly debilitated in their ability to recombine. The function of the replicase linker region where both mutations are located and their involvement in the virus recombination mechanism of the PVX replicase, as well as a possible involvement of host proteins remains elusive. Han et al. (52) speculated that the potexvirus replicase linker might represent a flexible region which allows a dynamic interaction between MT and HEL during the replication process. We can only speculate that the pentapeptide insertion in the two replicase amino acid positions 430 and 434 interferes with this dynamic interaction necessary for a possible template switch of the molecule. Only few studies on the influence of replicase mutants on recombination from other model viruses have been carried out. In BMV (Genus Bromovirus) non-homologous and homologous recombination both are affected by mutation in the HEL as well as the POL domains of the replicase $(33,35,36,76)$. In the Genus Tombusvirus Panaviene \& Nagy (80) found evidence for an RNA-binding region of the replicase of Cucumber necrosis virus to be involved in RNA-recombination. In both model viruses, replicase mutations have been detected, which differently affect levels of replication and recombination which is in accordance to our findings. These findings question the popular model anticipating that replication and recombination are closely connected and recombination can be understood as a replicase error like mutation. Recombination allows sexual reproduction of RNA viruses and allows genetic exchange between and reconstitution of different parental genomes with different deleterious mutations (20). This is especially important for viruses with monopartite genomes as they are unable to produce reassortants. We therefore suggest that this PVX replicase linker region might possess a 
distinct recombination function vital for maintenance of the genome integrity in presence of high mutation rates as they are well-known for RNA viruses (26). The system developed here, has the potential to characterize this linker region in more detail as site-directed mutations or deletions in the PVX replicase in viral background can be produced and now easily tested for their recombination efficiency. Finally this experimental system can be adapted for the easy and straightforward characterization of recombination parameters of other viruses as well, where full-length cDNA clones for agroinfection or particle bombardment are available.

\section{ACKNOWLEDGMENTS}

We kindly acknowledge Prof. David Baulcombe for the gift of pGR106 vector. D. Silhavy is acknowledged for providing the pBIN61S plasmid. Heidrun-Katharina Draghici was sponsored by a research fellowship (grant no. VA202/3-2) of the Deutsche Forschungsgemeinschaft (DFG).

\section{REFERENCES}

1. Aaziz, R., and M. Tepfer. 1999a. Recombination in RNA viruses and in virusresitent transgenic plants. J. Gen. Virol. 80:1339-1346.

2. Aaziz, R., and M. Tepfer. 1999b. Recombination between genomic RNAs of two cucumoviruses under condition of minimal selection pressure. Virology 263: 282-289.

3. Adair, T. L., and C. M. Kearney. 2000. Recombination between a 3-kilobase tobacco mosaic virus transgene and a homologous viral construct in the restoration of viral and nonviral genes. Arch. Virol. 145:1867-1883.

4. Adams, M. J., J. F. Antoniw, M. Bar-Joseph, A. A. Brunt, T. Candresse, G. D. Foster, G. P. Martelli, R. G. Milne, and C. M. Fauquet. 2004. The new plant virus family Flexiviridae and assessment of molecular criteria for species demarcation. Arch. Virol. 149:1045-1060. 
5. Alejska, M., A. Kurzynska-Kokornika, M. Broda, R. Kierzek, and M. Figlerowicz. 2001. How RNA viruses exchange their genetic material. Acta Biochimica Polonica 48(2):391-407.

6. Alejska, M., M. Figlerowicz, N. Malinowska, A. Urbanowicz, and M. Figlerowicz. 2005. A universal BMV-based RNA recombination system-how to search for general rules in RNA recombination. Nucleic Acids Res. 33:1-14.

7. Allison, R. F., G. Thompson, and P. Ahlquist 1990. Regeneration of a functional RNA virus genome by recombination between deletion mutants and requirement for cowpea chlorotic mottle virus $3 \mathrm{a}$ and coat genes for systemic infection. Proc. Natl. Acad. Sci. USA 87:1820-1824.

8. Allison, R. F., W. L. Schneider, and A. E. Greene. 1996. Recombination in plants expressing viral transgenes. Semin. Virol. 7:417-422.

9. Arnold, J.J., and C. E. Cameron. 1999. Poliovirus RNA-dependent RNA polymerase (3Dpol) is sufficient for template switching in vitro. J. Biol. Chem. 274:2706-2716.

10. Banner, L. R., J. G. Keck, and M. M. C. Lai. 1990. A clustering of RNA recombination sites adjacent to hyper-variable region of the peplomer gene of murine coronavirus. J. Virol. 175:548-555.

11. Barajas, D., F. Tenllado, and J. R. Diaz-Ruiz. 2006. Characterization of the recombinant forms arising from a Potato virus $X$ chemeric virus infection under RNA silencing pressure. MPMI 19(8): 904-913.

12. Baulcombe, D. C., S. Chapman, and S. Santa Cruz. 1995. Jellyfish green fluorescent protein as a reporter for virus infections. The Plant Journal 7(6):1045-1053. 
13. Beck, D. L., and W. O. Dawson. 1990. Deletion of repeated sequences from tobacco mosaic virus mutants with two coat protein genes. Virology 177:462469.

14. Borja, M., T. Rubio, H. B. Scholthof, and A. O. Jackson. 1999. Restoration of wild-type virus by double recombination of tombusvirus mutants with a host transgene. MPMI 12:153-162.

15. Brown, D., and L. Gold. 1996. RNA replication by Qß replicase: a working model. Proc Natl Acad Sci USA 93:11558-11562.

16. Bruyere, A., M. Wantroba, S. Flasinski, A. Dzianott, and J. J. Bujarski. 2000. Frequent homologous recombination events between molecules of one RNA component in a multipartite RNA virus. J. Virol. 74:4214-4219.

17. Bujarski, J. J., and P. Kaesberg. 1986. Genetic recombination between RNA components of a multipartite plant virus. Nature 321:528-531.

18. Canto, T., S. K., Choi, and P. Palukaitis. 2001. A subpopulation of RNA 1 of cucumber mosaic virus contains $3^{\prime}$ termini originating from RNAs 2 or 3. J. Gen. Virol. 82:941-945.

19. Cascone, P. J., T. F. Haydar, and A. E. Simon. 1993. Sequences and structures required for recombination between virus-associated RNAs. Science 260:801805.

20. Chao, L. 1997. Evolution of sex and the molecular clock in RNA viruses. Gene 205: $301-308$.

21. Chapman, S., T. Kavanagh, and D. C. Baulcombe. 1992. Potato virus X as a vector for gene expression in plants. The Plant Journal 2(4):549-557.

22. Chare, E. R., and E. C. Holmes. 2006. A phylogenetic survey of recombination frequency in plant RNA viruses. Arch. Virol. 151:933-946. 
23. Chetverin, A. B., H. V. Chetverina, A. A. Demidenko, and V. I. Ugarov. 1997. Nonhomologous RNA recombination in a cell-free system: Evidence for a transesterification mechanism guided by secondary structure. Cell 88:503-513.

24. Chetverina, H. V., A. A. Demidenko, V. I. Ugarov, and A. B. Chetverin. 1999. Spontaneous rearrangements in RNA sequences. FEBS Lett. 450:89-94.

25. Chung, B. N., T. Canto, and P. Palukaitis. 2007. Stability of recombinant plant viruses containing genes of unrelated plant viruses. J. Gen. Virol. 88(4):1347-55.

26. Crotty, S., C.E., Cameron, and R. Andino. 2001. RNA virus error catastrophe: Direct molecular test by using ribavirin. Proc. Natl. Acad. Sci. USA. 98:68956900 .

27. de Wispelaere, M., S. Gaubert, S. Trouilloud, C. Belin, and M. Tepfer. 2005. A map of the diversity of RNA3 recombinants appearing in plants infected with Cucumber mosaic virus and Tomato aspermy virus. Virology 331:117-127.

28. Domingo, E., and J. J. Holland. 1997. RNA virus mutations and fitness for survival. Annual Review of Microbiology 51:151-178.

29. Domingo, E., C. Escarmis, L. Menéndez-Arias, and J. J. Holland. 1999. Viral quasi-species and fitness variations. In: Origin and Evolution of Viruses. Eds. Domingo E., Webster R.G., Holland J.J. San Diego: Academic.141-161.

30. Domingo, E., E. Baranowski, C. Escarmis, F. Sobrino, and J. J. Holland. 2002. Error frequencies of picornavirus RNA polymerases: evolutionary implications for virus populations. In: Molecular biology of picornaviruses. Eds. Semler B.L., Wimmer E. Washington: ASM. 285-298.

31. Draghici, H. K., R. Pilot, H. Thiel, and M. Varrelmann. 2009. Functional mapping of PVX RNA-dependent RNA-replicase using pentapeptide scanning mutagenesis - Identification of regions indispensable for replication and subgenomic RNA amplification. Virus Research (in press). 
32. Duggal, R., and E. Wimmer. 1999. Genetic recombination of poliovirus in vitro and in vivo: temperature-dependent alteration of crossover sites. Virology 258:30-41.

33. Dzianott, A., N. Rauffer-Bruyere, and J. J. Bujarski. 2001. Studies on functional interaction between brome mosaic virus replicase proteins during RNA recombination, using combined mutants in vivo and in vitro. Virology 289:137149.

34. Fernández-Cuartero, B., J. Burgyán, M. A. Aranda, K. Salánki, E. Moriones, and F. García-Arenal. 1994. Increase in the relative fitness of a plant virus RNA associated with its recombinant nature. Virology 203:373-377.

35. Figlerowicz, M., P. D. Nagy, and J. J. Bujarski. 1997. A mutation in the putative RNA polymerase gene inhibits nonhomologous, but not homologous, genetic recombination in an RNA virus. Proceedings of the National Academy of Sciences, USA 94:2073-2078.

36. Figlerowicz, M., P. D. Nagy, N. Tang, C. C. Kao, and J. J. Bujarski. 1998. Mutations in the $\mathrm{N}$ terminus of the brome mosaic virus polymerase affect genetic RNA-RNA recombination. J. Virol. 72:9192-9200.

37. Figlerowicz, M., and J. J. Bujarski. 1998. RNA recombination in brome mosaic virus, a model plus stranded RNA virus. Acta Biochim. Polon. 45:1-23.

38. Fu, K., and R. S. Baric. 1992. Evidence for variable rates of recombination in the MHV genome. Virology, 189:88-102.

39. Gal, S., B. Pisan, T. Hohn, N. Grimsley, and B. Hohn. 1992. Agroinfection of transgenic plants leads to viable cauliflower mosaic virus by intermolecular recombination. Virology 187:525-533.

40. Gallei, A., A. Pankraz, H. J. Thiel, and P. Becher. 2004. RNA recombination in vivo in the absence of viral replication. J. Virol. 78:6271-6281. 
41. Gal-On, A., E. Meiri, B. Raccah, and V. Gaba. 1998. Recombination of engineered defective RNA species produces infective potyvirus in planta. J. Virol. 72:5268-5270.

42. García-Arenal, F., A. Fraile, and J. M. Malpica. 2001. Variability and genetic structure of plant virus populations. Annu Rev Phytopathol 39:157-186.

43. García-Arenal, F., A. Fraile, and J. M. Malpica. 2003. Variation and evolution of plant virus populations. Int. Microbiol. 6:225-232.

44. Gmyl, A. P., E. V. Belousov, S. V. Maslova, E. V. Khitrina, A. B. Chetverin, and V. I. Agol. 1999. Nonreplicative RNA recombination in poliovirus. J. Virol. 73:8958-8965.

45. Gmyl, A. P., S. A. Korshenko, E. V. Belousov, E. V. Khitrina, and V. I. Agol. 2003. Nonreplicative homologous RNA recombination: promiscuous joining of RNA pieces? RNA. 9:1221-1223.

46. Gmyl, A. P., and V. I. Agol. 2005. Diverse mechanisms of RNA recombination. Molecular Biology 39(4):529-542.

47. Goldbach, R., and P. de Haan. 1994. RNA viral supergroups and the evolution of RNA viruses. In The Evolutionary Biology of Viruses. 105-119. Edited by S. Morse. New York: Raven Press.

48. Greene, A. E., and R. F. Allison. 1994. Recombination between viral RNA and transgenic plant transcripts. Science 263:1423-1425.

49. Greene, A. E., and R. F. Allison. 1996. Deletions in the 3' untranslated region of cowpea chlorotic mottle virus transgene reduce recovery of recombinant viruses in transgenic plants. Virology 225:231-234. 
50. Gray, D. J., E. Hiebert, C. M. Lin, M. E. Compton, D. W. McColley, R. J. Harrison, and V. P. Gaba. 1994. Simplified construction and performance of a device for particle bombardment. Plant Cell, Tissue and Organ Culture 37:179184.

51. Habili, N., and R. H. Symons. 1989. Evolutionary relationship between luteoviruses and other RNA plant viruses based on sequence motifs in their putative RNA polymerases and nucleic acid helicases. Nucleic Acids Res. 17(23):9543-9555.

52. Han, Y. T., C. S. Tsai, Y. C. Chen, M. K. Lin, Y. H. Hsu, and M. Meng. 2007. Mutational analysis of a helicase motif-based RNA 5'-triphosphatase/NTPase from bamboo mosaic virus. Virology 367(1):41-50.

53. Hellens, R. P., E. A. Edwards, N. R. Leyland, S. Bean, and P. M. Mullineux. 2000. pGreen: a versatile and flexible binary Ti vector for Agrobacteriummediated plant transformation. Plant Molecular Biology 42:819-832.

54. Hoekema, A., P. R. Hirsch, P. J. J. Hooykaas, and R. A. Schilperoort. 1983. A binary plant vector strategy based on separation of vir- and T- region of the Agrobacterium tumefaciens Ti-plasmid. Nature 303:179-180.

55. Huisman, M. J., B. J. C., Cornelissen, C. F. M., Groenendijk, J. F., Bol, and L. van Vloten-Doting. 1989. Alfalfa mosaic virus temperature-sensitive mutants. $\mathrm{V}$. The nucleotide sequence of TBS 7 RNA 3 shows limited nucleotide changes and evidence for heterologous recombination. Virology 171:409-416.

56. Jakab, G., F. E. Vaistij, E. Droz and P. Malnoë. 1997. Transgenic plants expressing viral sequences create a favourable environment for recombination between viral sequences. In Virus-Resistant Transgenic Plants: Potential Ecological Impact. 45-51. Edited by M. Tepfer \& E. Balázs. Versailles \& Heidelberg: INRA \& Springer-Verlag. 
57. Jarvis, T. C., and K. Kirkegaard. 1992. Poliovirus RNA recombination: mechanistic studies in the absence of selection. EMBO J. 11:3135-3145.

58. Jones, L., A. J. Hamilton, O. Voinnet, C. L. Thomas, A. J. Maule, and D. C. Baulcombe. 1999. RNA-DNA interactions and DNA methylation in posttranscriptional gene silencing. Plant Cell 11:2291-2301.

59. Kagiwada, S., Y. Yamaji, H. Nakabayashi, M. Ugaki, and S. Namba. 2002. The complete nucleotide sequence of Potato virus $X$ strain OS: the first complete sequence of a Japanese isolate. J. Gen. Plant Pathol. 68:94-98.

60. Kirkegaard, K., and D. Baltimore. 1986. The mechanism of RNA recombination in poliovirus. Cell 47(3):433-443.

61. Kim, M. J., and C. Kao. 2001. Factors regulating template switch in vitro by viral RNA-dependent RNA polymerases: implications for RNA-RNA recombination. Proc. Natl. Acad. Sci. USA 98:4972-4977.

62. Kong, F., K. Sivakumaran, and C. Kao. 1999. The N-Terminal Half of the Brome Mosaic Virus 1a Protein Has RNA Capping-Associated Activities: Specificity for GTP and S-Adenosylmethionine. Virology 1:200-210.

63. Koonin, E. V., and V. V. Dolja. 1993. Evolution and taxonomy of positivestrand RNA viruses: implications of comparative analysis of amino acid sequences. Critical Reviews in Biochemistry and Molecular Biology 28(5):375430.

64. Li, Y.I., Y.M., Cheng, Y.L., Huang, C.H., Tsai, Y.H., Hsu, and M. Meng. 1998. Identification and characterization of the Escherichia coli-expressed RNAdependent RNA polymerase of bamboo mosaic virus. J. Virol. 72:10093-10099.

65. Li, Y.I., Y.J., Chen, Y.H., Hsu, and M. Meng. 2001a. Characterization of the AdoMet-dependent guanylyltransferase activity that is associated with the $\mathrm{N}$ terminus of bamboo mosaic virus replicase. J. Virol. 75:782-788. 
66. Li, Y.I., T.W., Shih, Y.H., Hsu, Y.T., Han, Y.L., Huang, and M. Meng. 2001b. The helicase-like domain of plant Potexvirus replicase participates in formation of RNA 5' cap structure by exhibiting RNA 5'-triphosphatase activity. J. Virol. 75:12114-12120.

67. Lommel, A., and Z. Xiong. 1991. Reconstitution of a functional red clover necrotic mosaic virus by recombinational rescue of the cell-to-cell movement gene expressed in a transgenic plant. Journal of Cellular Biochemistry 15A (suppl.): 151 .

68. Lu, R., I. Malcuit, P. Moffett, M. T. Ruiz, J. Peart, A. J. Wu, J. P. Rathjen, A. Bendahmane, L. Day, and D. C. Baulcombe. 2003. High throughput virus induced gene silencing implicates heat shock protein 90 in plant disease resistance. EMBO J. 22:5690-5699.

69. Masuta, C., S. Ueda, M. Suzuki, and I. Uyeda. 1998. Evolution of a quadripartite hybrid virus by interspecific exchange and recombination between replicase components of two related tripartite RNA viruses. Proc. Natl. Acad. Sci. USA 95:10487-10492.

70. Miller, E. D., C. A. Plante, K. H. Kim, J. W. Brown, and C. Hemenway. 1998. Stem-loop structure in the 5 'region of potato virus $X$ genome required for plus-strand RNA accumulation. J. Mol. Biol. 284:591-608.

71. Nagy, P. D., and J. J. Bujarski. 1993. Targeting the site of RNA-RNA recombination in brome mosaic virus with antisense sequences. Proc. Natl. Acad. Sci. USA 90:6390-6394.

72. Nagy, P. D., and J. J. Bujarski. 1995. Efficient system of homologous RNA recombination in brome mosaic virus: sequence and structure requirements and accuracy of crossovers. J. Virol. 69:131-140. 
73. Nagy, P. D., and J. J. Bujarski. 1997. Engineering of homologous recombination hotspots with AU-rich sequences in brome mosaic virus. J. Virol. 71:3799-3810.

74. Nagy, P. D., and A. E. Simon. 1997. New insights into the mechanisms of RNA recombination. Virology 235:1-9.

75. Nagy, P. D., and A. E. Simon. 1998. In vitro characterization of late steps of RNA recombination in turnip crinkle virus. I. Role of the motifl-hairpin structure. Virology 249:379-392.

76. Nagy, P. D., A., Dzianott, P., Ahlquist, and J.J. Bujarski 1995. Mutations in the helicase-like domain of protein 1a alter the sites of RNA-RNA recombination in Brome mosaic virus. J. Virol. 69: 2547-2556

77. Nagy, P. D., C. Zhang, and A. E. Simon. 1998. Dissecting RNA recombination in vitro: role of RNA sequences and the viral replicase. EMBO J. 17:2392-2403.

78. Olsthoorn, R. C. L., A. Bruyére, A. Dzianott, and J.J. Bujarski. 2002. RNA recombination in brome mosaic virus: effects of strand-specific stemloop inserts. J. Virol. 76: 12654-12662.

79. Panavas, T., and P. D. Nagy. 2003. Yeast as a model host to study replication and recombination of defective interfering RNA of tomato bushy stunt virus. Virology, 314: 315-325.

80. Panaviene, Z., and P.D. Nagy. 2003. Mutations in the RNA-binding domains of tombusvirus replicase proteins affect RNA recombination in vivo. Virology 317:359-372.

81. Prasher, D. C., V. K. Eckenrode, W. W. Ward, F. G. Prendergast, and M. J. Cormier. 1992. Primary structure of the Aequorea victoria green-fluorescent protein. Gene 111:229-233. 
82. Puchta, H. 2005. The repair of double-strand breaks in plants: mechanisms and consequences for genome evolution. Journal of Experimental Botany 56(409): $1-14$.

83. Roossinck, M. J. 1997. Mechanisms of plant virus evolution. Annual Review of Phytopathology 35:191-209.

84. Sambrook, J., E. F. Fritsch, and T. Maniatis. 1989. Molecular cloning: a laboratory manual. 2nd ed. Cold Spring Harbor Laboratory, Cold Spring Harbor, N.Y.

85. Santa Cruz, S., and D. C. Baulcombe. 1995. Analysis of potato virus X coat protein genes in relation to resistance conferred by the genes $N x, N b$ and $R x 1$ of potato. Journal of General Virology 76:2057-2061.

86. Silhavy, D., A. Molnar, A. Lucioli, G. Szittya, C. Hornyik, M. Tavazza, and J. Burgyán. 2002. A viral protein suppresses RNA silencing and binds silencinggenerated, 21- to 25-nucleotide double-stranded RNAs. EMBO J. 21:3070-3080.

87. Shapka, N., and P. D. Nagy. 2004. The AU-rich RNA recombination hot spot sequence of brome mosaic virus is functional in tombusviruses: implications for the mechanism of RNA recombination. J. Virol. 78:2288-2300.

88. Sherpa, A. R., Hallan, V., Pathak, P., and A. A. Zaidi. 2007. Complete nucleotide sequence analysis of Cymbidium mosaic virus Indian isolate: further evidence for natural recombination among potexviruses. J. Biosci. 32:663-669.

89. Tzfira, T., J. Li, B. Lacroix, and V. Citovsky. 2004. Agrobacterium T-DNA integration: molecules and models. Trends in Genetic 20(8):375-383.

90. Van der Heijden, M. W., and J. F. Bol. 2002. Composition of alphavirus-like replication complexes: involvement of virus and host encoded proteins. Arch. Virol. 147:875-898. 
91. Van der Kuyl, A. C., L. Neeleman, and J. F. Bol. 1991. Complementation and recombination between alfalfa mosaic virus RNA3 mutants in tobacco plants. Virology 183:731-738.

92. Varrelmann, M., L. Palkovics, and E. Maiss. 2000. Transgenic or plant expression vector-mediated recombination of plum pox virus. J. Virol. 74:74627469.

93. Voinnet, O., C. Lederer, and D. C. Baulcombe. 2000. A viral movement protein prevents spread of the gene silencing signal in Nicotiana benthamiana. Cell 103:157-167.

94. White, K. A., and T. J. Morris. 1994. Recombination between defective tombusvirus RNAs generates functional hybrid genomes. Proc. Natl. Acad. Sci. USA 91:3642-3646.

95. Yeh T. Y., B. Y. Lin, Y. C. Chang, Y. H. Hsu, and N. S. Lin. 1999. A defective RNA dissociated with bamboo mosaic virus and the possible common mechanisms for RNA recombination in Potexviruses. Virus Genes 18(2):121-128.

96. Zhang, C., P. J. Cascone, and A. E. Simon. 1991. Recombination between satellite and genomic RNAs of turnip crinkle virus. Virology, 184:791-794. 


\section{KAPITEL 4}

\section{Potato virus $X$ RNA recombination is determined by structural parameters and occurs frequently at preferentially predicted stem-loop structures}

The goal of this study was the development of an experimental system to efficiently study the structural parameters of potato virus X (PVX) RNA recombination. We used again the system of agroinfection by intercellular leaf space infiltration for expression of a PVX coat protein mutant carrying a GFP marker and a functional CP transcript to study RNA recombination (reviewed in Draghici \& Varrelmann, 2009; manuscript submitted in Journal of Virology). Applying mutants with different deletions and variable sequence homology, we were able to characterize time-point, homology length dependence of recombination and found evidence that recombination junction sites were influenced by RNA secondary structure.

\section{MATERIALS AND METHODS}

PVX strains. To obtain CP-genes with variable sequence homology in comparison to PVX-UK3 (type X, Group 3, Kagiwada et al., 2002; Kirkegaard and Baltimore, 1986), PVX type X isolates (Santa Cruz and Baulcombe, 1995) from different geographic origins were obtained [isolates PVX-14, PVX-17 (both Germany), PVX-18 (Afghanistan) and PVX-847 (Iran), kindly supplied by Stefan Winter (Plant Virus Department, German Collection of Microorganisms and Cell Cultures, Braunschweig, Germany)] and propagated on Nicotiana benthamiana plants. A PVX subtype Bi, isolate PVX-4 (Group 4) (Santa Cruz and Baulcombe, 1995) displaying higher sequence divergence compared to UK3 was kindly provided by Rene van der Vlugt (Plant Research International, Wageningen, The Netherlands).

Sequence analyzes. Sequence alignment was carried out using the neighbor joining algorithms in the ClustalX version 1.83 program (Thompson, et al., 1997). The RNA secondary structure of parental $(+)$ strand CP-gene plus 3 '-ntr sequences were predicted for PVX-UK3 and PVX-4 at $37^{\circ} \mathrm{C}$ with $150 \mathrm{bp}$ maximum distance between paired bases, using 
Mfold version 3.2 (http://frontend.bioinfo.rpi.edu/applications/mfold/cgi-bin/rnaform1.cgi) based on free energy minimization (Mathews et al., 1999; Zuker, 2003).

Clones and infectious transcripts. If identity of clones had to be confirmed DNA sequencing was performed by a commercial company (Eurofins MWG Operon, Martinsried, Germany). All recombinant plasmid manipulations were performed as described previously (Sambrook et al., 1989) unless otherwise specified. The 35S-driven PVX plant expression plasmid cloned in a binary vector for agroinfection (pGr106, 60, 67, GenBank accession no. AY297843) used in this study was obtained from David Baulcombe (Sainsbury Laboratory, Norwich, UK). The construction of PVX (isolate UK3) plant expression vector expressing green fluorescent protein (GFP) named 35S-PVX-GFP has been described previously in Draghici et al. (2009).

35S-PVX-GFP derived mutants. The construction of PVX coat protein (CP) deletion mutant, named 35S-PVX-GFP- $\triangle \mathrm{CP}$ was described previously (Draghici et al., 2009). To generate CP-deletion mutants with different lengths in 35S-PVX-GFP, the following strategy was applied. The 3 '-end of the GFP gene, the subgenomic CP-promoter and the 5 '-end of the CP-gene with variable lengths were PCR-amplified with specific primers using 35S-PVX-GFP template. The upper primer CP-del-up (5'AATCTGCCCTTTCGAAAGAT-3') (restriction sites in all primers underlined and virus specific sequences in italics) homologous to a part of the GFP ORF (open reading frame) contained a Bsp119I restriction site for subsequent exchange in 35S-PVX-GFP and used for the generation of all CP-deletion mutants. Different lower CP-primers (supplied with an $\mathrm{XhoI}$ restriction site) were used which together with primer CP-del-up produced CP-gene fragments of different lengths. The different PCR-fragments were Bsp119I-XhoI cloned into 35S-PVX-GFP, replacing most of the CP-ORF and resulting in the generation of CP-mutants with fixed 3 '-end length (nt 653-711) and 5 '-end of variable lengths $(0$, nt $0-10,-20,-50,-101,-200,-300,-401,-500$ and -600 respectively). The resulting clones were named: 35S-PVX-GFP-CP-0, -10, -20, -50, -101, $-200,-300,-401,-500$ and -600 respectively (Fig. 1) and were subsequently applied in the recombination assay. 


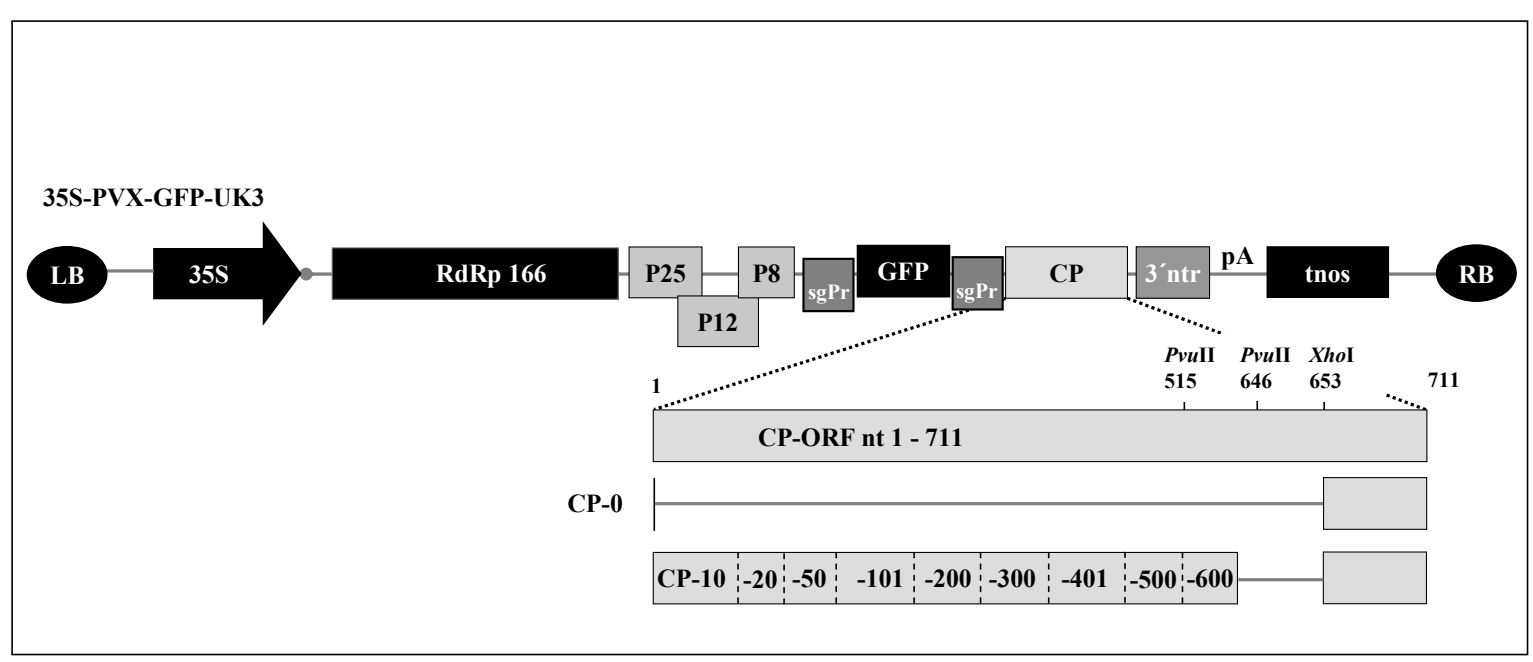

Fig. 1. 35S-PVX-GFP CP-deletion mutants. Schematic representation of 35S-PVX-GFP and derived CPdeletion mutants (not drawn to scale): LB and RB, left and right T-DNA border sequences; 35S, 35S promoter of cauliflower mosaic virus; RdRp, 166K, RNA-dependent RNA polymerase ORF; 25K, 8K and 12 $\mathrm{K}$, triple gene block ORFs (TGB); sgPr, subgenomic CP promoter; GFP, green fluorescent protein ORF; CP, coat protein ORF; 3'-ntr, 3'-nontranslated region; pA, CaMV poly(A) terminator; tnos, nopaline synthase transcriptional terminator; restriction sites $(P v u \mathrm{II}, \mathrm{XhoI})$. The complete PVX CP-ORF includes $711 \mathrm{bp}$ and is illustrated as a light grey box. CP-deletion mutants 35S-PVX-GFP-CP-0, -10, -20, -50, -101, -200, -300, $401,-500$ and -600 are marked by dashed lines.

\section{Construction of binary vectors, expressing the complete CP-gene and 3 '-ntr in} vivo transcripts derived from different PVX isolates. The exact PVX-CP ORF and complete 3'-ntr region of PVX-UK3, PVX-14, PVX-17, PVX-18 and PVX-847 respectively was RT-PCR-amplified from total RNA extracts (RNeasy, Qiagen) of virus infected N. benthamiana leaf tissue introducing flanking SacI and BamHI restriction sites. The following primers were used: CP-up (5'-TTAGAGCTCACCATGTCAGC $A C C A G C T A G C A C-3$ ') and poly-T-low. In order to amplify the respective sequence from a PVX $\mathrm{Bi}$ type isolate PVX-4, a derivative upper primer CP4-UP (5'-TTAGAGCTCACCATGACTACACCAGCTAGCAC-3') was applied. The PCR fragments were SacI-BamHI-cloned in a binary vector pBIN61S under control of the enhanced CaMV 35S-promotor and polyA-terminator (Silhavy et al., 2002). Plasmid inserts obtained were sequence verified and named 35S-CP-UK3, -PVX-14, -PVX-17, -PVX-18, -PVX-847 and -PVX-4 respectively. 
Cloning and sequencing of CP-gene and 3'ntr from recombinant $\mathrm{PVX}$ isolates. Upper leaves of $N$. benthamiana plants used in the (PVX) recombination assay, displaying systemic infection as monitored by GFP-fluorescence were used for total RNA extraction and RT-PCR amplification of PVX CP-gene and 3'-ntr as described previously in Draghici \& Varrelmann (2009, manuscript submitted in Journal of Virology).

Recombination assay. All binary vectors were transformed into Agrobacterium tumefaciens LBA4404 (Hoekema et al., 1983) using electroporation. To produce PVXGFP-UK3 with recombinant CP-gene, 35S-PVX-GFP- $\triangle \mathrm{CP}$ was co-infiltrated with $35 \mathrm{~S}$ CP-UK3, -PVX-14, -PVX-17, -PVX-18, -PVX-847 and -PVX-4, respectively. In general the recombination assay was performed as described previously in Draghici \& Varrelmann (2009, manuscript submitted in Journal of Virology).

Epifluorescence microscopy (FM). Agroinfiltrated $N$. benthamiana leaf patches were monitored for GFP fluorescence using epifluorescence microscopy as specified in Draghici \& Varrelmann (2009, manuscript submitted in Journal of Virology).

\section{RESULTS}

The frequency of functional PVX CP-gene reconstitution by means of recombination is inverse proportional to the distance between mutations. We intended to analyze the relation of recombination frequency to the length of overlapping homologous sequence between PVX CP-mutants carrying variable deletion lengths and intact CP transcripts. We assumed a proportional relationship and a possible minimal region of homologous sequence overlap necessary for successful reconstitution by means of recombination. Moreover we aimed to figure out, if PVX recombines via replicative RdRp template switching between homologous sequences or if an RNA-ligation activity without requirement of homologous overlapping sequences might be the basis for recombination. To achieve this, several 35S-PVX-GFP CP-deletion mutants were constructed (35S-PVX-GFP-CP-0, -10, -20, -50, -101, -200, -300, -401, -500 and -600 in Fig. 1) and each co-expressed with $35 \mathrm{~S}-\mathrm{CP}-\mathrm{UK} 3$ in five $N$. benthamiana plants (four infiltrated leaf patches each) respectively in two independent experiments. PVX expressed GFP-fluorescence was monitored over time using UV-illumination starting at 3 until 17 dpi (Table 1). The first spreading recombinant virus was detected at 8 dpi when mutant 
35S-PVX-GFP-CP-600 was applied. For the mutants 35S-PVX-GFP-CP-500 to -CP-101, the first recombinant virus movement was observed at 10 dpi and for -CP-50 at 12 dpi, whereas for the mutants -CP-20, -CP-10 and -CP-0, no PVX spreading at all was detectable in the time period analyzed (Table 1). In addition the total number of agroinfiltrated patches displaying virus movement finally observed at 17 dpi correlated well to the length of sequence overlap.

Table 1. Time dependent occurrence of PVX recombinants in relation to the length of sequence overlap available for recombination. Number of $N$. benthamiana leaf patches infiltrated with 35S-PVX-GFP displaying CP-deletions of different length (20 patches each treatment) and intact 35S-CP-UK3.

\begin{tabular}{|c|c|c|c|c|c|c|c|c|c|c|c|c|c|c|c|c|c|c|c|c|}
\hline \multirow{2}{*}{$\begin{array}{c}\text { 35S-PVX-GFP-CP } \\
\text { Mutants }\end{array}$} & \multicolumn{2}{|c|}{$\begin{array}{c}8 \\
\text { dpi } \\
\end{array}$} & \multicolumn{2}{|c|}{$\begin{array}{c}9 \\
\text { dpi }\end{array}$} & \multicolumn{2}{|c|}{$\begin{array}{c}10 \\
\text { dpi }\end{array}$} & \multicolumn{2}{|c|}{$\begin{array}{c}11 \\
\text { dpi }\end{array}$} & \multicolumn{2}{|c|}{$\begin{array}{c}12 \\
\text { dpi }\end{array}$} & \multicolumn{2}{|c|}{$\begin{array}{c}13 \\
\text { dpi }\end{array}$} & \multicolumn{2}{|c|}{$\begin{array}{c}14 \\
\text { dpi }\end{array}$} & \multicolumn{2}{|c|}{$\begin{array}{c}15 \\
\text { dpi }\end{array}$} & \multicolumn{2}{|c|}{$\begin{array}{c}16 \\
\text { dpi }\end{array}$} & \multicolumn{2}{|c|}{$\begin{array}{c}17 \\
\text { dpi }\end{array}$} \\
\hline & I & II & I & II & I & II & $\mathbf{I}$ & II & 1 & II & $\mathbf{I}$ & II & $\mathbf{I}$ & II & $\mathbf{I}$ & II & I & II & $\mathbf{I}$ & II \\
\hline CP-0 del 652 bp & 0 & 0 & 0 & 0 & 0 & 0 & 0 & 0 & & 0 & 0 & 0 & 0 & 0 & 0 & 0 & 0 & 0 & 0 & 0 \\
\hline CP-10 del 642 bp & 0 & 0 & 0 & 0 & 0 & 0 & 0 & 0 & 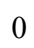 & 0 & 0 & 0 & 0 & 0 & 0 & 0 & 0 & 0 & 0 & 0 \\
\hline CP-20 del 632 bp & 0 & 0 & 0 & 0 & 0 & 0 & 0 & 0 & & 0 & 0 & 0 & 0 & 0 & 0 & 0 & 0 & 0 & 0 & 0 \\
\hline CP-50 del 602 bp & 0 & 0 & 0 & 0 & 0 & 0 & 0 & 0 & 2 & 0 & 3 & 1 & 3 & 1 & 4 & 1 & 4 & 1 & 4 & 1 \\
\hline CP-101 del 551 bp & 0 & 0 & 0 & 0 & 2 & 1 & 2 & 1 & & 1 & 4 & 2 & 5 & 2 & 5 & 2 & 7 & 3 & 7 & 3 \\
\hline CP-200 del 452 bp & 0 & 0 & 0 & 0 & 3 & 1 & 4 & 1 & & 1 & 8 & 2 & 8 & 3 & 11 & 5 & 12 & 8 & 12 & 8 \\
\hline CP-300 del 352 bp & 0 & 0 & 0 & 0 & 1 & 1 & 2 & 1 & & 2 & 7 & 4 & 9 & 4 & 10 & 5 & 10 & 6 & 11 & 8 \\
\hline CP-401 del 251 bp & 0 & 0 & 0 & 0 & 2 & 1 & 3 & 2 & & 3 & 6 & 4 & 9 & 5 & 10 & 5 & 12 & 7 & 13 & 9 \\
\hline CP-500 del 152 bp & 0 & 0 & 0 & 0 & 5 & 2 & 6 & 4 & 9 & 5 & 11 & 6 & 12 & 6 & 14 & 8 & 15 & 10 & 16 & 13 \\
\hline CP-600 del 52 bp & 1 & 1 & 3 & 3 & 5 & 4 & 6 & 5 & 8 & 7 & 10 & 8 & 13 & 9 & 13 & 12 & 15 & 13 & 17 & 15 \\
\hline
\end{tabular}

I and II = independent repetition of the experiment

Use of intact PVX CP-genes with sequence variability allows determining the composition of the recombinant $C P$ sequence and the number of RdRp template switches. Due to missing marker mutations the recombination of PVX-UK3 with the homologous UK3 CP-gene did not allow to determine neither the number of template switches nor the preferred recombination regions/sites up- and downstream ( $3^{\prime}$ and $\left.5^{\prime}\right)$ of the CP gene deletion. Therefore 4 different PVX type $\mathrm{X}$ isolates where used for cloning and sequencing of the CP-gene $+3^{\prime}$-ntr region (PVX-14, -17, -18 and -847). ClustalX alignment revealed 100\% 3'-ntr sequence homology between all isolates and isolate- 
depending, 20-31 nucleotide exchanges out of total 711 bp CP-ORF (95.6-97.2\% sequence homology) compared to CP-UK3 (Fig. 2). As most of these mutations were silent and located $5^{\prime}$ of the deletion in CP-UK3, leading only in three positions to aa exchanges (data not shown), we assumed functionality of chimeric CPs and no selection for recombinants with specific compositions. Therefore all 35S-driven CP +3 ' -ntr expression clones (35SCP-PVX-14, -17, -18 and -847) were applied in the recombination assay (five $N$. benthamiana plants, four patches each) with $35 \mathrm{~S}-\mathrm{PVX}-\mathrm{GFP}-\mathrm{CP}-\Delta \mathrm{CP}$. In unexpected contrast, the first recombinants in two independent repetitions occurred at least one day earlier (7 instead of 8-9 dpi) when the divergent CP-genes were applied in the recombination assay (Table 2).

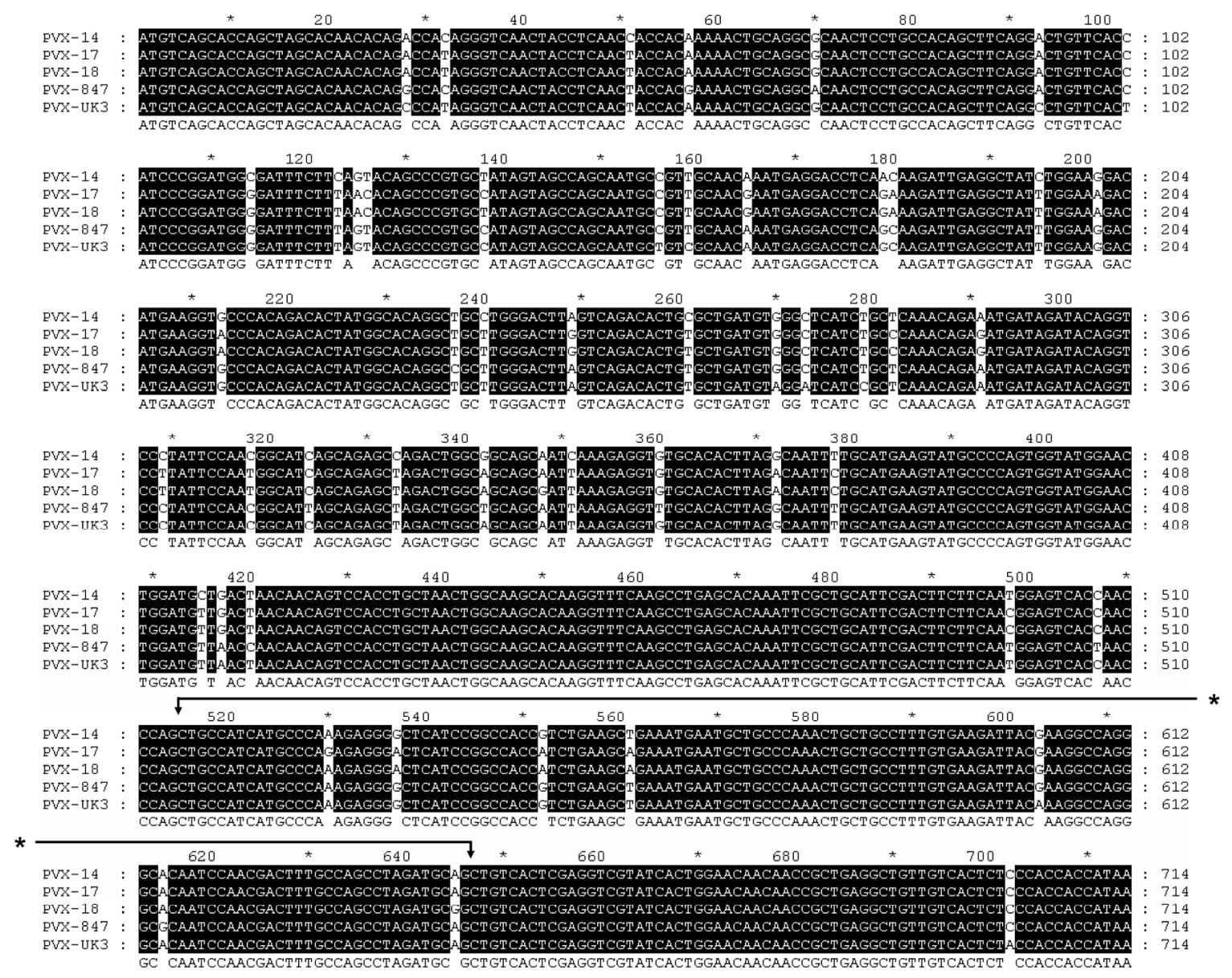

Fig. 2. ClustalX alignment of the CP-ORFs of different PVX type $X$ isolates and PVX-UK3. (*) indicates $P v u$ II CP gene deletion in UK3 template. Nucleotide numbering is according to PVX-UK3, -14, -17, -18 and -847 CP ORF respectively. 
Table 2. Properties of chimeric PVX recombinant CP-genes derived from recombination of PVX-UK3 CP-gene and divergent CP-genes of four different type X isolates

\begin{tabular}{|c|c|c|c|c|c|c|c|}
\hline \multirow{2}{*}{$\begin{array}{c}\text { PVX isolate } \\
\text { used for } \\
\text { CP-transcript } \\
\text { generation }\end{array}$} & \multicolumn{2}{|c|}{$\begin{array}{l}\text { Sequence divergence } \\
\text { compared to CP-UK3 }\end{array}$} & \multirow{2}{*}{$\begin{array}{c}\text { No. of } \\
\text { infiltrated } \\
\text { patches } \\
\text { displaying } \\
\text { PVX } \\
\text { movement }\end{array}$} & \multirow{2}{*}{$\begin{array}{l}\text { Recombinant } \\
\text { no. analysed }\end{array}$} & \multirow{2}{*}{$\begin{array}{c}\text { No. of } \\
\text { template } \\
\text { switches } \\
\text { detected }\end{array}$} & \multirow{2}{*}{$\begin{array}{c}\text { Aa } \\
\text { composition } \\
\text { selected }\end{array}$} & \multirow{2}{*}{$\begin{array}{c}\text { Recombinant } \\
\text { properties: } \\
\text { unique or } \\
\text { identical to } \\
\text { recombinant } \\
\text { no. }\end{array}$} \\
\hline & $\begin{array}{l}\text { No. of nt } \\
\text { exchanges }\end{array}$ & $\begin{array}{c}\text { aa } \\
\text { exchanges }\end{array}$ & & & & & \\
\hline \multirow{5}{*}{ PVX-14 } & \multirow{5}{*}{24} & \multirow{5}{*}{$\begin{array}{l}\text { P10T } \\
\text { I11T } \\
\text { S60N }\end{array}$} & \multirow{5}{*}{$16 / 20$} & 1 & 1 & CP-UK3 & 5 \\
\hline & & & & 2 & 1 & CP-UK3 & 3 \\
\hline & & & & 3 & 1 & CP-UK3 & 2 \\
\hline & & & & 4 & 7 & CP-UK3 & Unique \\
\hline & & & & 5 & 1 & CP-UK3 & 1 \\
\hline \multirow{5}{*}{ PVX-17 } & \multirow{5}{*}{29} & \multirow{5}{*}{$\begin{array}{l}\text { P10T } \\
\text { S42N } \\
\text { S60R }\end{array}$} & \multirow{5}{*}{$16 / 20$} & 1 & 5 & CP-UK3 & Unique \\
\hline & & & & 2 & 1 & CP-UK3 & Unique \\
\hline & & & & 3 & 7 & CP-UK3 & Unique \\
\hline & & & & 4 & 3 & $\begin{array}{l}\text { chimera } \\
\text { (PNR)* }\end{array}$ & Unique \\
\hline & & & & 5 & 1 & CP-17 & Unique \\
\hline \multirow{5}{*}{ PVX-18 } & \multirow{5}{*}{31} & \multirow{5}{*}{$\begin{array}{l}\text { P10T } \\
\text { S42N } \\
\text { S60R }\end{array}$} & \multirow{5}{*}{$17 / 20$} & 1 & 3 & $\begin{array}{l}\text { chimera } \\
\text { (PSR)* }\end{array}$ & 2 \\
\hline & & & & 2 & 3 & $\begin{array}{l}\text { chimera } \\
\text { (PSR)* }\end{array}$ & 1 \\
\hline & & & & 3 & 5 & $\begin{array}{l}\text { chimera } \\
\text { (PSR)* }\end{array}$ & Unique \\
\hline & & & & 4 & 5 & $\begin{array}{l}\text { chimera } \\
\text { (PSR)* }\end{array}$ & Unique \\
\hline & & & & 5 & 3 & UK3 & Unique \\
\hline \multirow{5}{*}{ PVX-847 } & \multirow{5}{*}{20} & \multirow{5}{*}{$\begin{array}{l}\text { P10A } \\
\text { I11T } \\
\text { A24T }\end{array}$} & \multirow{5}{*}{$10 / 20$} & 1 & 7 & $\begin{array}{l}\text { chimera } \\
(\mathrm{PTT})^{*}\end{array}$ & Unique \\
\hline & & & & 2 & 7 & CP-847 & unique \\
\hline & & & & 3 & 1 & CP-UK3 & unique \\
\hline & & & & 4 & 4 & CP-UK3 & unique \\
\hline & & & & 5 & 3 & $\begin{array}{l}\text { chimera } \\
(\mathrm{PTT})^{*}\end{array}$ & unique \\
\hline
\end{tabular}

* Composition of the variable aas. 
However the recombination frequency in the time-period observed was comparable to the recombination assay applying the homologous CP-UK3 gene. At 10 dpi five $N$. benthamiana plants of each treatment displaying GFP-fluorescence in non-inoculated leaves were used for upper leaf sampling, cloning and sequencing of recombinant $\mathrm{CP}$-genes, to detect sequence variation of recombinants in the different treatment. As the $3^{\prime}$-ntr displayed $100 \%$ homology between all isolates, we were unable to state on which template the RdRp initiated minus-strand synthesis. As one template switch would be sufficient to reconstitute a functional $\mathrm{CP}$ if the initiation of transcription would take place on the intact CP transcript; this was anticipated for all recombinants analyzed. Sequence analysis of the overall 20 recombinants supported this hypothesis, showing that the nucleotide at the most 3 '-end position 702 in the CP-ORF, divergent in all 4 different isolates compared to CP-UK3, was mutant in 18/20 recombinants analyzed. Recombinant sequence alignment of the different treatments revealed several interesting characteristics. Independent of the four CP-sequences applied for recombination, many recombinants sequenced displayed variable properties [number of template switches (recombination events), marker mutations], which resulted in some cases in recombinants with variable aa composition (Fig. 3 and summarized in Table 2). Although the deletion in CP-UK3 gene covering nt 515-646 could have been repaired by RdRp template switch in 5'-proximity to the deletion from the 35S-CP transcript to the intact UK3 strand and completion of viral minus strand synthesis, this did not occur most frequently. 13/20 recombinants were a product of more than one template switch. In contrast 3 recombinants with 7 detectable template switches (PVX-14 Rec4 and PVX-847 Rec1 and 2) were observed. Sequence analysis additionally revealed that most of the recombinant sequences were unique (14/20). In addition, no evidence was found for selection of a specific composition in the variable aas (Table 2). All aa differences between PVX-UK3 and PVX-14, -17, -18 and -847 respectively were located in the N-terminal 60 aas (data not shown). The CP-UK3 deletion (aa 171-215) was not affecting these aa positions. This would theoretically allow the reconstitution of a recombinant $\mathrm{CP}$ with wild-type composition. However, several recombinants encoding chimeric or even the entire intact $\mathrm{CP}$ sequence offered for recombination were detected (Table 2). Comparison between recombinants derived from one treatment as well as between different treatments did not reveal preferred regions for RdRp template switch or a hint for recombination hot spots. Even the recombination events leading to CP-gene reconstitution by only one single template switch in 7 recombinants seemed to be spread homogenously over the CP-ORF (Fig. 3). 
(A)
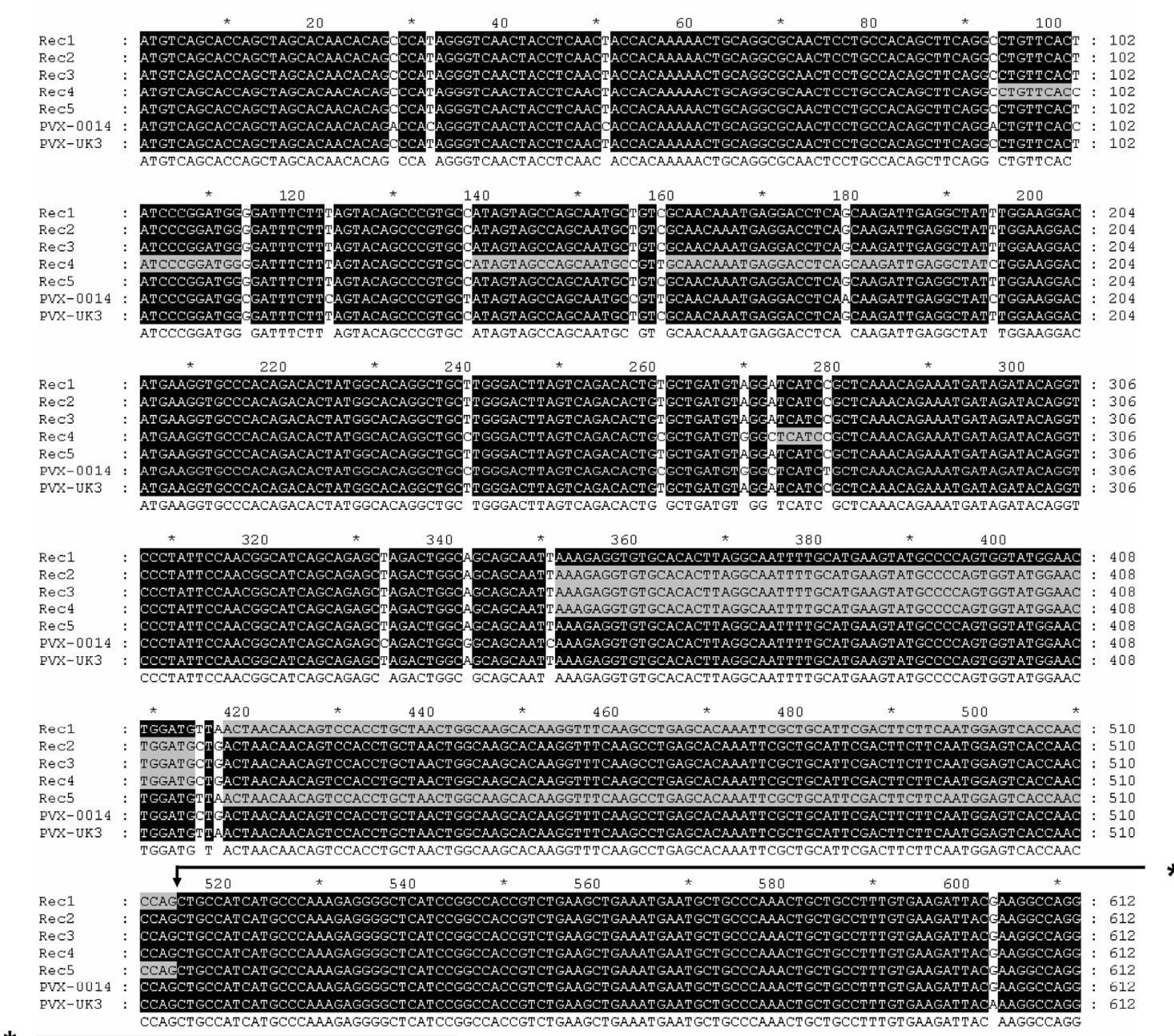

*
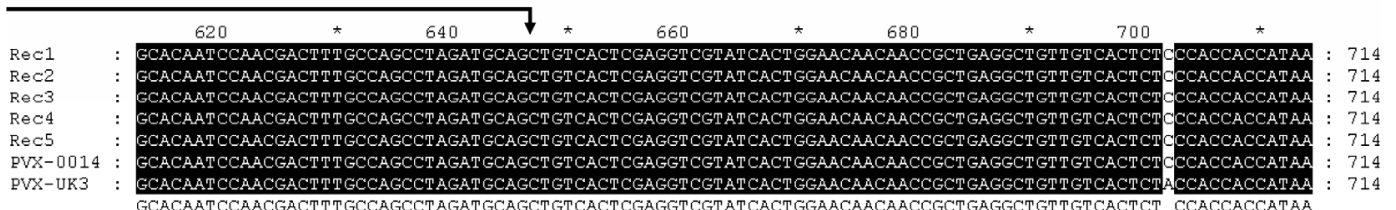
(B)
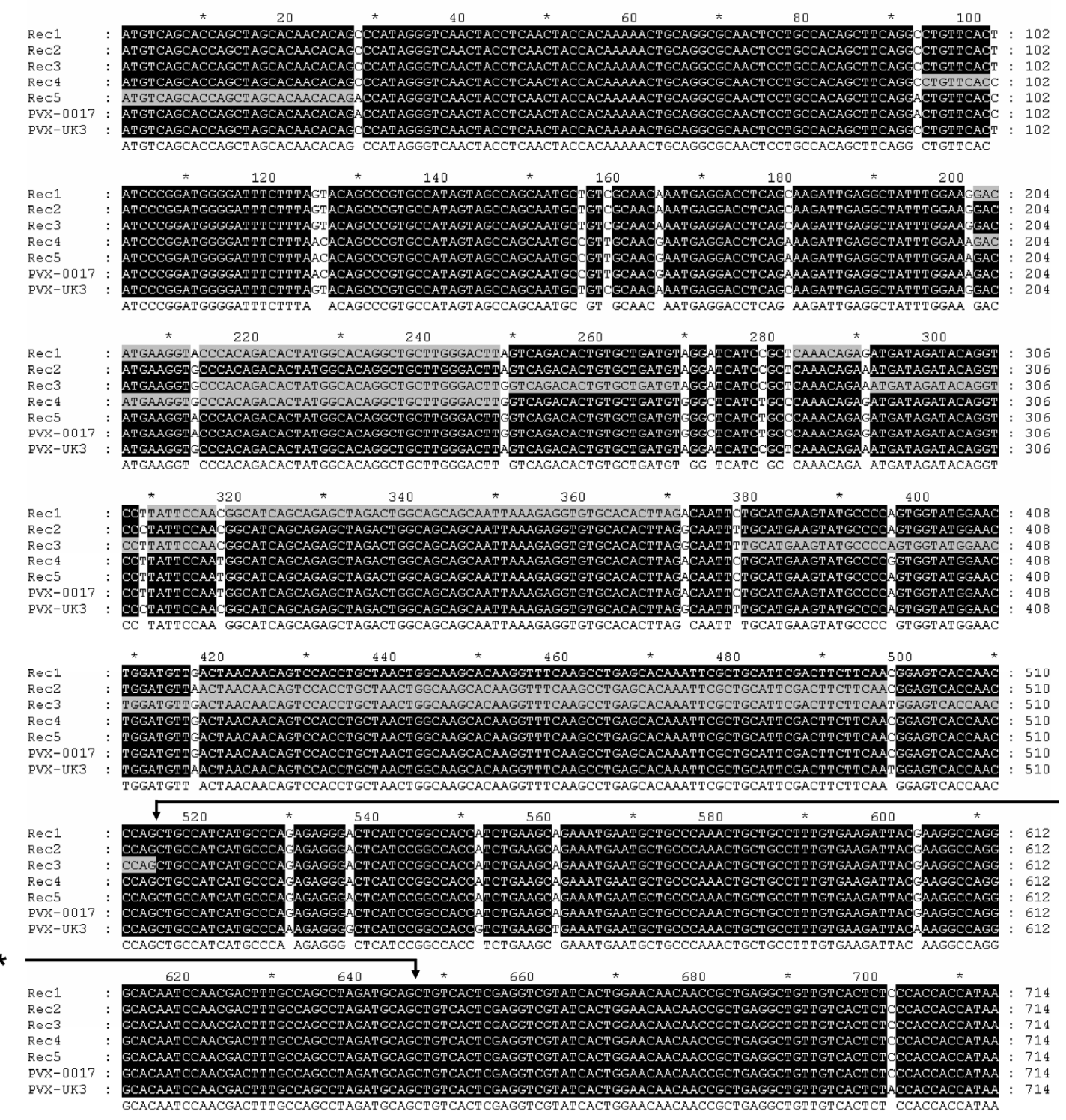
(C)
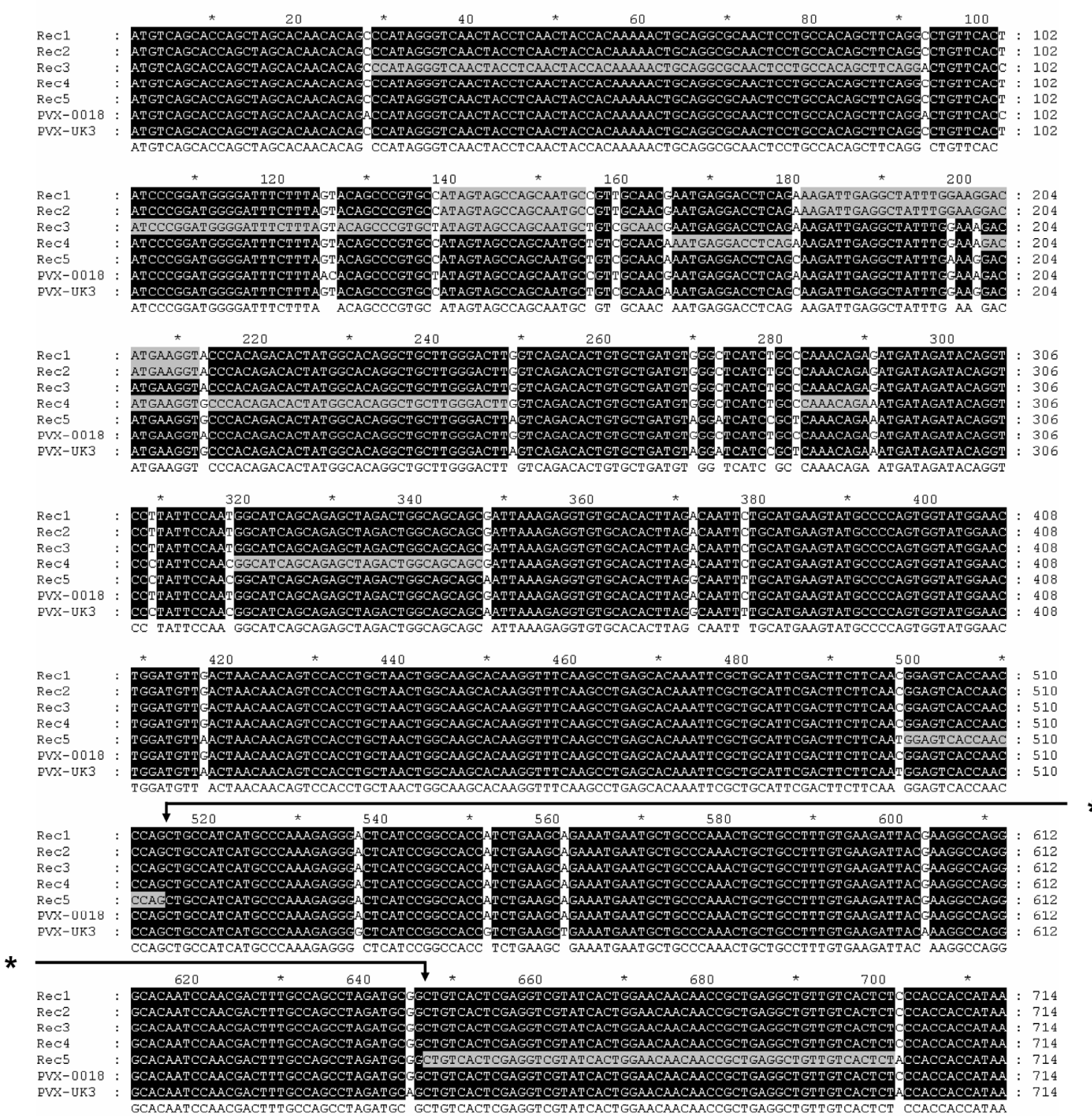
(D)

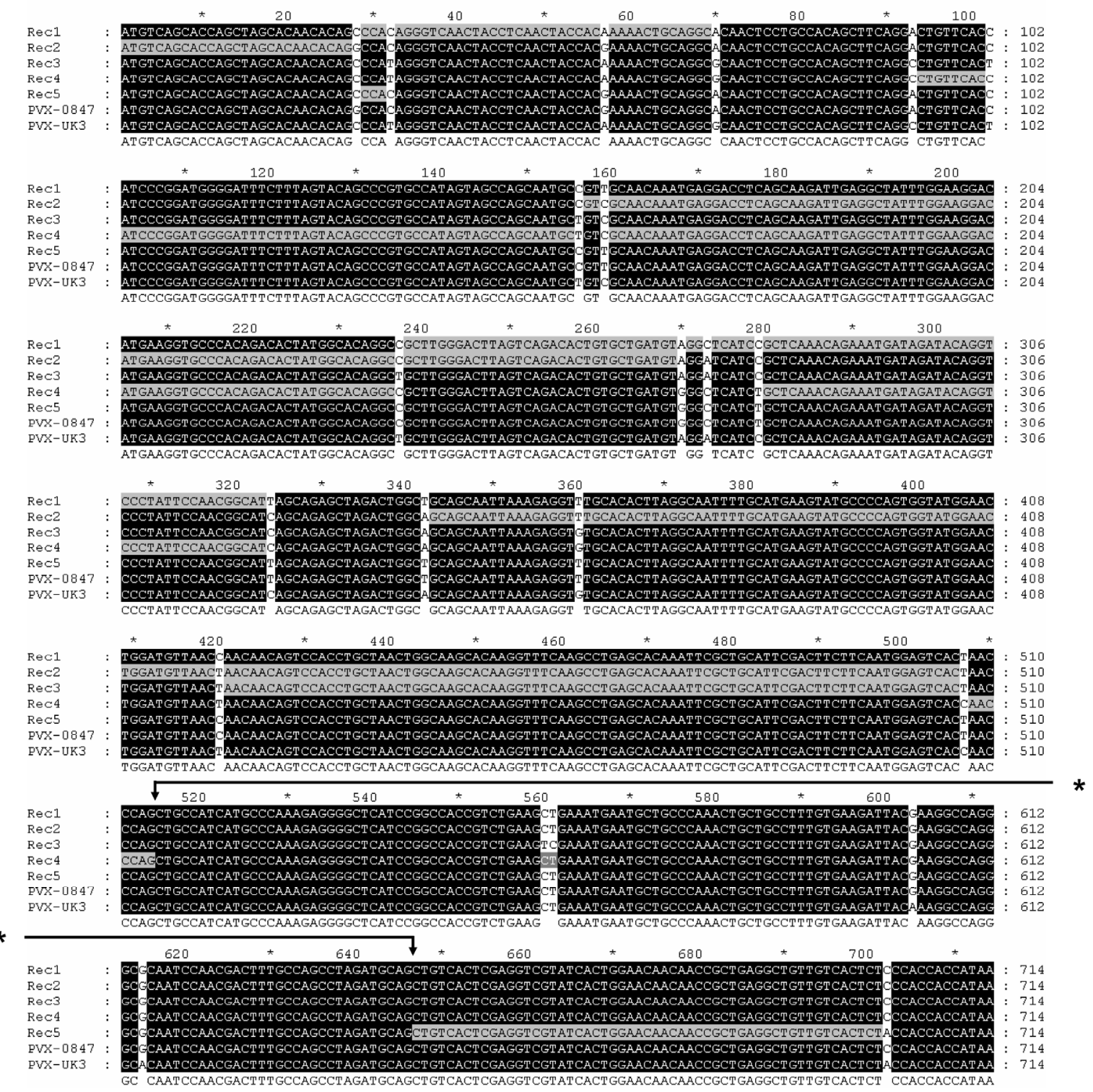

Fig 3. ClustalX alignment of PVX-UK3 and different PVX-CP gene sequences: PVX-0014 (A), -0017 (B), -0018 (C) and -0847 (D) CP-gene plus 3'-ntr and CP respectively in comparison to five recombinants (Rec1Rec5) respectively. (*) indicates PvuII CP gene deletion in UK3 template. Recombination regions between mutations where template switch occurred are highlighted in grey. 
A coat protein transcript plus 3 '-ntr from a phylogenetic distant PVX type Bi isolate reconstitutes PVX-UK3 CP deletion mutant and allows more precise determination of recombination sites. In a previous study Santa Cruz and Baulcombe (1995) compared PVX CP-genes from different PVX type X displaying 97-99\% and type $\mathrm{B}$ ( $\mathrm{Bi}$ and Bii subtypes) isolates showing less homology down to $77 \%$ nucleic acid sequence homology. In order to apply in the recombination assay a CP-gene containing a higher number of marker mutations, an intact Bi type CP-gene was selected to study the recombination with CP-UK3 type $\mathrm{X}$ deletion mutant. This experiment should supply the information, if recombination would occur at all, at which frequency and preferred sites and if a specific chimeric CP would be selected. A PVX type B isolate (PVX-4, kindly supplied by Rene van der Vlugt) was used for cloning and sequencing of CP-gene +3 '-ntr. This revealed a PVX Bi type strain CP-gene and 3 'ntr displaying only 75.1\% CP-gene and $76.8 \%$ CP-gene plus 3 '-ntr sequence homology to CP-UK3 respectively. As described in Santa Cruz and Baulcombe (1995), CP-PVX-4 as a Bi type isolate contained an insertion of $33 \mathrm{bp}$ in the $3^{\prime}$-end (Fig. 4). The more or less uniform spread of $187 \mathrm{bp}$ exchanges in the CP-ORF and 5 bp in the 3 '-ntr promised to enable us to determine more precisely the recombination junction sites (necessary to reconstitute the CP-UK3 deletion mutant). Compared to recombination with variable type X CP-genes, the recombination frequency observed when applying CP-PVX-4 transcripts was severely reduced. Only 21/208 patches displayed virus movement at 14 dpi compared to 72/104 patches of parallel treated CP-UK3 recombination control. To determine the sequence composition of different individual recombinants, 15 plants showing systemic GFP-fluorescence were used for cloning and sequencing of the CP-gene $+3^{\prime}$-ntr. The ClustalX alignment of the CP-gene plus 3 '-ntr of PVX-UK3, PVX-4 and 15 recombinants revealed that all recombinants were unique on the nucleotide level (Fig. 4). Again, theoretically one single template switch would have been sufficient to reconstitute a complete CP gene. However, this was only detected in PVX-4-Rec1, 5, 7, 12 and 14. The remaining 10 recombinants displayed between two and seven template switches respectively. The $3^{\prime}$-ntr composition of the different recombinants showed that the most 3 '-nucleotide exchange at nt position 750 in the UK3-sequence (corresponding to position 783 in PVX-4) T (UK3) - C (PVX-4) displayed to be PVX-4 sequence in 10/15 recombinants (Fig. 4) demonstrating that in the majority of the recombinants the initiation of minus-strand synthesis had occurred on the intact PVX-4 transcript. In 15 recombinant CP-genes analyzed, 45 recombination junction sites were observed, out of which 27 were unique (Fig. 4, sequences highlighted in grey). 
ClustalX alignment of the aa composition revealed that only PVX-4-Rec2, 4, 10, 15 and 1, 12 respectively possessed identical composition, giving no evidence for selection of a chimeric CP with specific composition (data not shown). Remarkable is that none of the recombinants had acquired the most N-terminal part of the PVX-4 and that only PVX-4-Rec3 had acquired the PVX-4 CP specific 11 aa insertion. The recombination sites detected in the recombinants were not randomly distributed over CP-gene and 3 '-ntr but clustered to five sites in proximity to the deletion in CP-UK3 (designated I-V in Fig. 4) were 21/45 template switches were observed. The remaining sites appeared to be spread uniformly over the possible range available for recombination. 

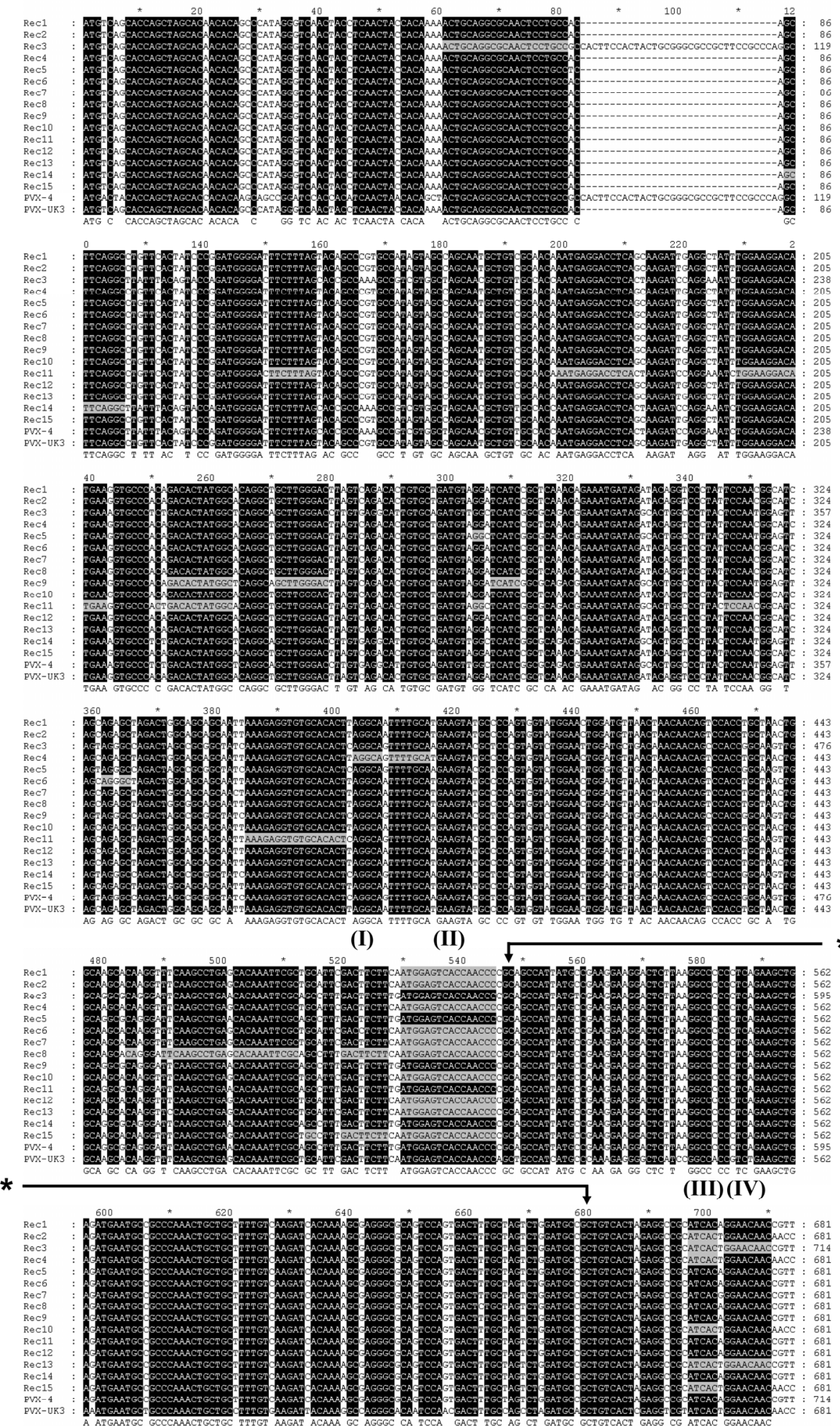

(V)

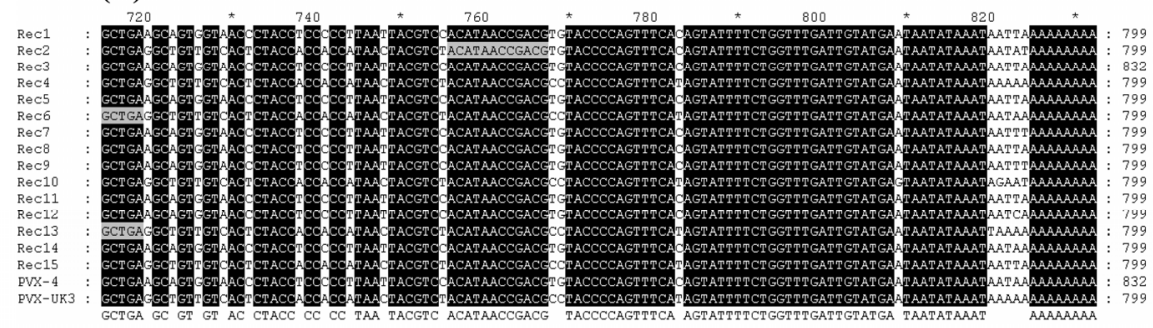


Fig. 4. ClustalX alignment of PVX-UK3 and PVX-4 CP gene plus 3 '-ntr compared to 15 recombinant CP genes named Rec1 to Rec15. Homologous regions are shaded in black. Recombination regions between mutations where template switch occurred are highlighted in grey. (*) indicates PvuII CP gene deletion in UK3 template. Independent template switch regions is proximity to the deletion in CP-UK3 are numbered $\mathrm{I}-\mathrm{V}$ (see Fig. 4). Nucleotide numbering is according to PVX-UK3, and -4 CP ORF, 3'ntr and poly-A terminator respectively.

\section{Precise homologous RNA recombination of PVX occurs preferentially at} predicted stem-loop structures. Assuming recombination to occur during minus strand synthesis, all parental sequences containing regions of possible RdRp template switch (Fig. 4) were used for RNA secondary structure prediction with the program Mfold 3.2. Analysis of regions I-V (Fig. 5) revealed folding into stem and loop structures. Remarkably 4/5 recombination sites overlapped with the predicted stem-loop and one template switch could be located directly to the loop. Analysis of the remaining 22 junction sites with more uniform distribution resulted in 13 cases in prediction of recombination site overlap with a predicted stem-loop (data not shown). 


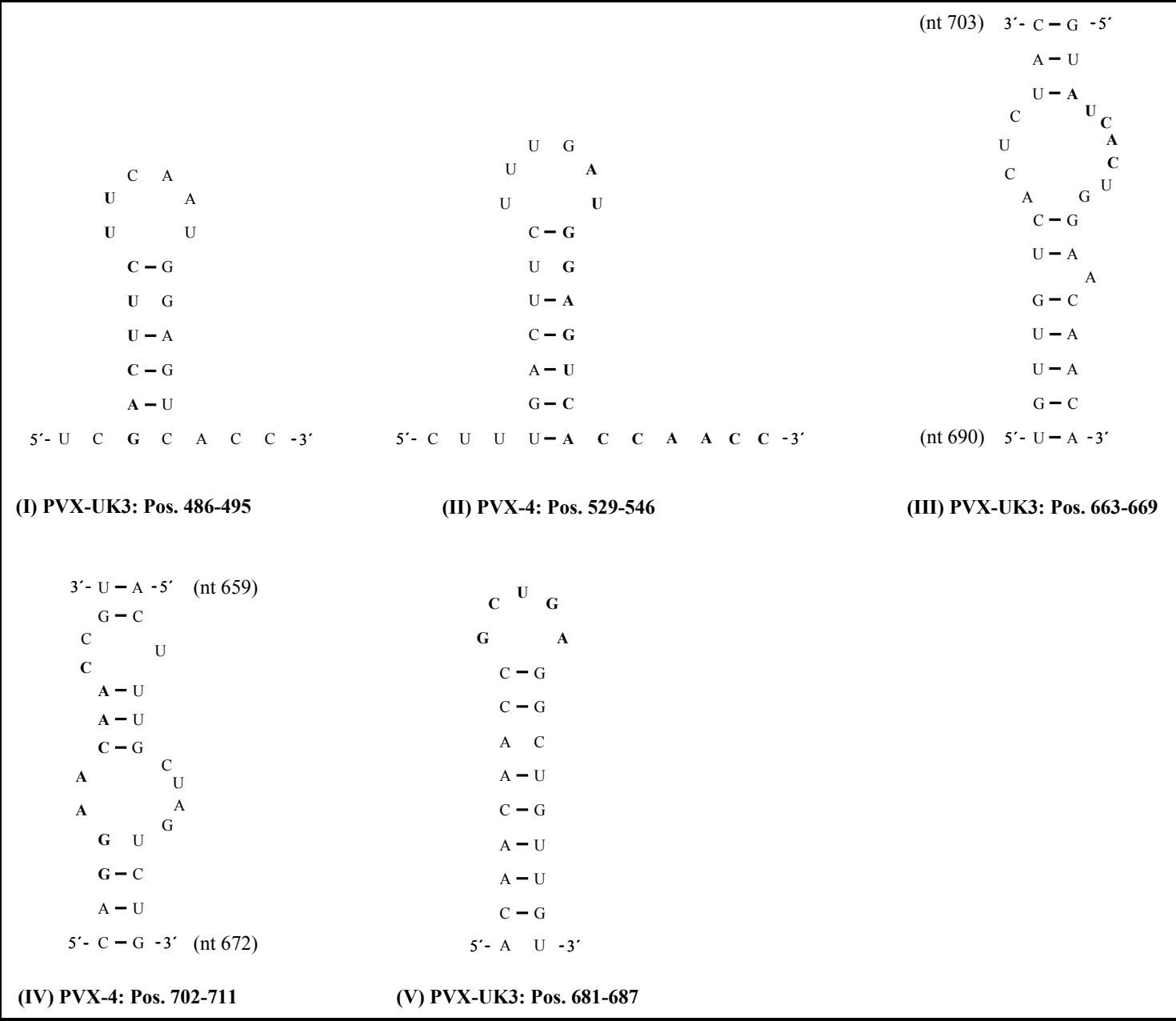

Fig. 5. RNA secondary structures of parental (+) strand CP-gene regions (PVX-4 or -UK3), were template switch in proximity to the CP-UK3 deletion (I-V in Fig. 4) occurred. The distance between mutations representing the possible region for RdRp template switch is indicated below each structure and highlighted in bold in the sequence. Nucleotide positions are according to PVX-4 and -UK3 CP-ORF respectively.

\section{REFERENCES}

Draghici, H. K., R. Pilot, H. Thiel, and M. Varrelmann. 2009. Functional mapping of PVX RNA-dependent RNA-replicase using pentapeptide scanning mutagenesis identification of regions indispensable for replication and subgenomic RNA amplification. (Virus Research, doi:10.1016/j.virusres.2009.03.013, in press).

Draghici, H. K., and M. Varrelmann. 2009. Efficient in vivo system to study the homologous recombination mechanism of potato virus $\mathrm{X}$ - evidence that the replicase linker region between methyltransferase and helicase domain is involved in RNA recombination. (manuscript submitted in Journal of Virology, no. JVI00179-08) 
Gray, D. J., E. Hiebert, C. M. Lin, M. E. Compton, D. W. McColley, R. J. Harrison, and V. P. Gaba. 1994. Simplified construction and performance of a device for particle bombardment. Plant Cell, Tissue and Organ Culture 37:179-184.

Hoekema, A., P. R. Hirsch, P. J. J. Hooykaas, and R. A. Schilperoort. 1983. A binary plant vector strategy based on separation of vir- and T- region of the Agrobacterium tumefaciens Ti-plasmid. Nature 303:179-180.

Kirkegaard, K. and D. Baltimore. 1986. The mechanism of RNA recombination in poliovirus. Cell 47(3):433-443.

Mathews, D. H., J. Sabina, M. Zuker, D. H. Turner. 1999. Expanded sequence dependence of thermodynamic parameters improves prediction of RNA secondary structure. J. Mol. Biol. 288:911-940.

Sambrook, J., E. F. Fritsch, and T. Maniatis. 1989. Molecular cloning: a laboratory manual. 2nd ed. Cold Spring Harbor Laboratory, Cold Spring Harbor, N.Y.

Santa Cruz, S., and D. C. Baulcombe. 1995. Analysis of potato virus X coat protein genes in relation to resistance conferred by the genes $N x, N b$ and $R x l$ of potato. Journal of General Virology 76:2057-2061.

Silhavy, D., A. Molnar, A. Lucioli, G. Szittya, C. Hornyik, M. Tavazza, and J. Burgyán. 2002. A viral protein suppresses RNA silencing and binds silencing-generated, 21- to 25-nucleotide double-stranded RNAs. EMBO J. 21:3070-3080.

Thompson, J. D., T. J. Gibson, F. Plewniak, F. Jeanmougin, and D. G. Higgins. 1997. The ClustalX windows interface: flexible strategies for multiple sequence alignment aided by quality analysis tools. Nucleic Acids Res. 24:4876-4882.

Zuker, M. 2003. Mfold web server for nucleic acid folding and hybridization prediction. Nucleic Acids Res. 31:3406-3415. 


\section{KAPITEL 5}

\section{Diskussion}

Potato virus X (PVX), Genus Potexvirus und Mitglied der Supergruppe III (,alpha-like“) Viren, wurde auf die Fähigkeit zu replizieren und rekombinieren kaum und bezüglich des Rekombinationsmechanismus bisher überhaupt nicht untersucht. Es wird jedoch vermutet, dass an allen genannten Prozessen die Replikase oder auch als RNA-abhängige RNAPolymeraase (RdRp) bezeichnet, beteiligt ist.

In Bezug auf die PVX-Replikation konnte Longstaff et al. (1993) die ReplikaseNotwendigkeit für die Replikation und RNA-Synthese in Protoplasten nachweisen. Weiterhin entdeckte Li et al. (1998) die in vitro template-abhängige RdRp-Aktivität im Bamboo mosaic virus (BaMV), wobei die RdRp gereinigt und in E. coli exprimiert wurde. Für die Rekombinationsfähigkeit konnten bereits Beobachtungen zum Vorkommen von Deletionen in PVX-Expressionsvektoren (die Fähigkeit, Insertionen aus dem Genom zu entfernen) und das Vorkommen von „Defective“ RNAs (D RNAs) bei BaMV nachgewiesen werden (Chapman et al., 1992; Yeh et al., 1999). Beide Nachweise sind wahrscheinlich auf Rekombination zurückzuführen und gelten somit als indirekter Rekombinationsnachweis.

Im ersten Teil der Arbeit wurde die funktionelle Charakterisierung der Replikasefunktion der PVX-Replikase erfolgreich durchgeführt. In Anlehnung an frühere in silico Sequenzuntersuchungen von (+)-Strang RNA-Viren (Koonin, 1991; Rozanov, 1992; Koonin \& Dolja, 1993) konnten bereits strukturell konservierte Domänen innerhalb der Replikase identifiziert werden. Diese waren die so genannte N-terminal gelegene putative Guanylyl-/ Methyltransferase (MT), zentrale RNA-Helikase (HEL) und C-terminale Polymerase (POL) Domäne, die signifikante Homologien $\mathrm{zu}$ anderen bekannten Replikaseproteinen aufzeigten (van der Heijden \& Bol, 2002). Innerhalb der 1456 As (Aminosäure) großen Potexvirus-Replikase waren diese konservierten Domänen an limitierten Regionen lokalisiert (MT: 59-224 As, HEL: 729-958 As, POL: 1160-1395 As, bezogen auf PVX). In Anlehnung an die Tatsache, dass in früheren biochemischen Studien (Kong et al., 1999; Li et al., 1998, 2001a und 2001b; Han et al., 2007) nur der gesamte Bereich der konservierten Domänen untersucht wurden und nicht wirklich in mehreren Optimierungsschritten sukzessive verkürzt vorlagen, müssten weitere Untersuchungen 
dieser Regionen vorgenommen werden. Im Detail bedeutet das, dass die Regionen, die den minimal essentiellen Bereich für die MT-, HEL- und POL Domäne vom Genus Potexvirus angeben sowie die, die sich zwischen den jeweiligen Domänen befinden, experimentell in weiteren Studien untersucht werden müssten.

Zunächst wurde während dieser Arbeit ein Aminosäure (As) Sequenzalignment der Replikase von 16 Spezies des Genus Potexvirus durchgeführt, mit dem Ergebnis, dass insgesamt eine Sequenzhomologie zwischen $34 \%$ und $65 \%$ vorlag. Nach eigenen Angaben konnten bisher nur Sequenzvergleiche der einzelnen Domänen (MT, HEL und POL) getrennt durchgeführt werden (van der Vlugt \& Berendsen, 2002; Liou et al., 2004). Wir konnten somit zeigen, dass auch die Sequenzen des kompletten Replikaseproteins auf Aminosäureebene mit der ClustalX-Software verglichen werden konnten, wobei schließlich die Separierung bzw. Trennung der Domänen überflüssig war. Wie bereits von Li et al. (2001a) und Han et al. (2007) am Beispiel des Bamboo mosaic virus (BaMV), Genus Potexvirus, postuliert wurde, war auffällig, dass sich zwischen MT- und HEL Domäne eine so genannte hydrophile Linkerregion (ca. 100 As) befand, die sich als sehr divergente Region widerspiegelte. Generell zeigte das Sequenzalignment der unterschiedlichen Spezies der Potexviren eine hohe Variabilität in Länge und Zusammensetzung. Das lässt vermuten, dass die konservierten Regionen bzw. Domänen durch die so genannte ,hyper-variable“ Linkersequenz voneinander getrennt sind, wobei jedoch der funktionelle Einfluss dieser Region bisher nicht untersucht wurde. Das bedeutet, wir können nur schlussfolgern, dass die Linkersequenz bzw. -region weder an der MT- noch an der HEL Domäne beteiligt ist. Um die Funktion bzw. Aktivität oder den Einfluss an der Replikation dieser „hyper-variable“ Linkersequenz genauer bestimmen zu können, müssten im Detail biochemische Studien durchgeführt werden.

Im Zuge dieser Arbeit wurde erstmalig eine systematisch funktionelle Studie einer Pflanzen-RNA-Replikase im viralen „,backround“ durchgeführt. Hierbei sollte der Einfluss der unterschiedlich konservierten und weniger konservierten Replikaseregionen innerhalb des Proteins in Bezug auf die Fähigkeit zu replizieren und die Genomamplifizierung in vivo, untersucht werden. Ermöglicht wurde das Experiment durch das Vorhandensein eines PVX GFP-markierten „full-length“ cDNA-Klons, der agroinfizierbar war, und von dem letztlich mit Hilfe des ,pentapeptide scanning“ (PS) Mutagenesesystems erfolgreich eine Insertionsbibliothek der PVX-Replikase mit 54 unabhängigen zufällig verteilten Mutanten innerhalb des Proteins erzeugt werden konnte. Die jeweiligen PS-Mutanten wurden anschließend, bezogen auf ihre Genomamplifizierung mittels indirekter Quantifizierung 
der subgenomischen RNA-Expression getestet. Hierzu wurde auf die Virus-exprimierte GFP-Fluoreszenz zurückgegriffen, die als Marker galt und eine visuelle Kategorisierung in drei Klassen bezüglich der replikationsaktiven Bereiche zuließ. Verglichen mit früheren Studien (Poussu et al., 2004 und 2005; Fransen et al., 2005; Varrelmann et al., 2007; Ghazala et al., 2008), die ebenfalls die Methode der PS-Mutagenese zur funktionellen Charakterisierung eines Proteins angewendet haben, ist unser Experiment ein zusätzliches Beispiel für die Proteinstabilität der PVX-Replikase, die nicht durch die 5 As-Insertionen beeinflusst bzw. zerstört wurde.

Wir konnten anhand der PS-Mutagenese erstmalig einen Bereich (410-619 As) in der „highly-variable“ Linkerregion der PVX-Replikase identifizieren, der bisher mit keiner der aus früheren Arbeiten bekannten konservierten Domänen (MT, HEL und POL) übereinstimmte. Die PS-Mutanten dieser Region zeigten eine Toleranz gegenüber der 5 Aminosäureinsertion und somit keine Einschränkung in ihrer Fähigkeit sich zu replizieren. Dieses Ergebnis wird unterstützt von biochemischen Studien mit erzeugten Deletionsklonen innerhalb der MT- und HEL- BaMV-Replikase, die gezeigt haben, dass dieser Bereich der „highly-variable“ Linkerregion entbehrlich war für die enzymatische Guanylyl/-Methyltransferase und RNA 5'-Triphosphatase/NTPase-Funktionen (Li et al., 1998, 2001a und b). Zwei PS-Mutanten konnten jedoch in dieser Region an Aminosäureposition 461 und 462 identifiziert werden, die intolerant gegenüber einer solchen Insertion waren. Infolgedessen kommt der „highly-variable“ Linkerregion eine Bedeutung in vivo zu, indem sie möglicherweise bei der Verbindung der Domänen und bei der Vermittlung von Interaktionen der beiden Domänen mitwirkt. In der konservierten MT Domäne konnte eine Vielzahl an PS-Mutanten identifiziert werden, die eine komplette Inaktivität bezüglich der Replikationsfähigkeit aufwiesen. Die Replikationsfähigkeit wurde immer dann vollständig zerstört, sobald die Domänen und umgebende Bereiche getroffen wurden, d.h. unabhängig davon, ob mit der ,,pentapeptide“ Insertion ein hochkonserviertes Aminosäure-Motiv getroffen wurde oder ob Bereiche mit höherer Variabilität die Insertion aufwiesen. Es bleibt jedoch reine Spekulation, ob eine Insertion diese replikative Funktion direkt oder indirekt durch Proteinsekundärstrukturen beeinflusst. Um solch eine Strukturinformation der neu zu bestimmenden Sequenz bzw. der jeweiligen PSInsertionsorte innerhalb der Domänen detailliert charakterisieren zu können, ist die Vorhersage der Sekundärstruktur von Proteinen für die Erkennung der entsprechenden Proteinfaltung unabdingbar. 
Innerhalb der HEL- und Pol Domäne konnten nur PS-Mutanten mit einer Intoleranz gegenüber der 5 As-Insertion identifiziert werden, wobei die gesamte Anzahl der Mutanten in einer Region von 679-1420 As (PS-Mutanten Nr. 40-69) nachzuweisen waren. Jede dieser Mutanten zerstörte die Fähigkeit des Virus sich zu replizieren, unabhängig davon, ob die Insertion mit den bekannten strukturell konservierten HEL- und POL Sequenzmotiven oder mit dem vermuteten aktiven Bereich des Proteins oder der InterRegionen korrelierte. Die hohe Intoleranz (Sensibilität) gegenüber der Insertionen innerhalb der HEL- und POL Domäne der PVX-Replikase lässt postulieren, dass die aaSequenzzusammensetzung der beiden benachbarten Domänen absolut notwendig bzw. essentiell ist für die virale Replikation in vivo und keine Veränderung der Sequenzabfolge zulässt. Diese Sensibilität ist in soweit erstaunlich, weil innerhalb von Potexviren nur eine relativ geringe Sequenzhomologie nachzuweisen war (Liou et al., 2004). Schlusfolgern lässt sich daraus, dass es sich bei dieser Varianz um eine Wirtsanpassung der jeweiligen Spezies an, z.B. bestimmte Wirte handeln könnte.

Die Insertionsbibliothek der PVX-Replikase weist final eine Dichte der Mutantenverteilung von durchschnittlich einer Mutante pro 28 Aminosäuren auf, wobei die funktionelle Karte der Replikase einige „gaps“ (Lücken bzw. Leerstellen) aufwies. Diese „gaps“ müssten in zukünftigen Untersuchungen, bezogen auf PS Mutagenese, ausgeschlossen bzw. über das gesamte PVX-Replikase-Protein dichter abgedeckt werden. Generell müssten weitaus mehr Klone ( $>210$ Klone) erzeugt werden, um eine signifikante, gesättigte Bibliothek von einem Protein mit einer Größe von 4368 bp erzeugen zu können. Es stellte sich somit die Frage, ob diese Methode der ,pentapeptide scanning“ Mutagenese (PSM) die richtige Wahl war, um ein Protein solch einer Größe im Detail zu charakterisieren. Die PSM liefert eine schnellere und effektivere Alternative gegenüber der „linker scanning“ Mutagenese (z.B. nach Dykxhoorn et al., 1997) bzw. „alanin scanning“ Mutagenese (Cunningham \& Wells, 1989). Bei den beiden letzt genannten handelt es sich um gerichtete Mutationen. Das ,,alanin scanning“ Mutageneseverfahren bewirkt somit zielgerichtete Punktmutationen, d.h. hierbei findet eine Substitution durch eine neutrale oder negativ geladene Aminosäure (bevorzugt wird hierbei Alanin oder Polyalanin) statt, um die Wechselwirkung der Aminosäuren mit der wässrigen Umgebung in oder außerhalb der Zelle zu erzeugen (Cunningham \& Wells, 1989). Diese Verfahren sind jedoch sehr zeitaufwendig und kostspielig. Allgemein liegt der Vorteil der PSM darin, dass hierbei nur eine geringe Insertion von 5 Aminosäuren notwendig ist und diese weiterhin in keinem der möglichen Leserahmen zu einer Leserasterverschiebung bzw. Stop-Codon führt (MGSTM 
Mutation Generation System, Finnzymes). Weiterhin liefert die PSM eine in vitro Reaktion, die ausreicht, um mehr als 1 Million Transposon-inserierte Klone zu erzeugen (MGS ${ }^{\text {TM }}$ Mutation Generation System, Finnzymes).

Es lässt sich schlussfolgern, dass eine Konservierung innerhalb des Potexvirus-ReplikaseAminosäure-Sequenzalignments hervorragend mit der Intoleranz oder der Sensibilität der Replikasefunktion gegenüber der 5 As-Insertion korreliert und letztlich der konservierte Bereich mit der Notwendigkeit für die Replikasefunktion gleichzusetzen ist. Hingegen wird eine 5 As-Insertion innerhalb der divergenten bzw. variablen Sequenzabfolge der Replikase der Potexviren toleriert, d.h. dieser Bereich ist nicht essentiell für die Replikationsfunktion. Frühere Studien von Ghazala et al. (2008), bezogen auf das 16K Protein des Tobacco rattle virus (TRV) konnten diese Schlussfolgerung bestätigen. Hierbei korrelierte ebenfalls eine Sequenzvariabilität innerhalb des Sequenzalignments des Genus Tobravirus mit einer Toleranz gegenüber der 5 As-Insertionen. $\mathrm{Zu}$ beachten sei hierbei jedoch, dass es sich bei dem PVX-Replikaseprotein um ein ca. 10-fach größeres Protein handelt, verglichen mit dem 16K Protein. Schlussfolgern lässt sich somit, dass so geringe Mutationen (5 As-Insertionen) dennoch eine derart negative Auswirkung auf ein Protein solcher Größe haben. Das Replikaseprotein ist somit weitaus komplexer als das 16K Protein, d.h. einzelne Aminosäuren oder Motive, aufgrund von Wechselwirkungen oder katalytische Eigenschaften sind genauso essentiell. Des Weiteren konnte eine hohe Divergenz der Replikase des Genus Potexvirus beobachtet werden, woraus sich folgende Fragestellungen ableiten lassen. Muss die Variabilität nur als eine Art der Wirtsanpassung angesehen werden oder handelt es sich bei den auftretenden Mutationen zwischen den Molekülen innerhalb der Spezies um eine Anpassung an 5'-und 3'-NTRs für ihre virusspezifische Erkennung? Hierfür müsste in weiteren Untersuchungen geklärt werden, wie viele dieser Spezies z.B. N. benthamiana als Wirt betrachten. Höchst interessant wäre auch zu klären, ob es möglich ist, Replikasen innerhalb der Spezies von Potexviren auszutauschen.

Im Allgemeinen werden zusätzlich zu der Deletions- und Insertions-Mutagenese, wobei die Sekundärstruktur höchstwahrscheinlich beeinflusst wird, Punktmutationen verwendet, um hauptsächlich funktionelle Domänen, Regionen und Motive abgrenzen zu können. Frühere PSM-Studien mit unterschiedlichen Proteinen und bereits vorhandenen Informationen über ihre Sekundärstruktur durch Röntgenstrukturanalysen, z.B. „X-ray“ Kristallographie (Cao et al., 1997; Hallet et al., 1997; Petyuk et al., 2004; Poussu et al., 2004 und 2005) demonstrierten, dass die Methode der „pentapeptide scanning“ 
Mutagenese signifikante Informationen über den Zusammenhang zwischen Struktur und Funktion eines Proteins lieferte. Sie konnten zeigen, dass die 5 As-Insertionen meistens in der Nähe des aktiven Bereichs des Proteins nachzuweisen waren. Um jedoch die Zusammenhänge zwischen Struktur und Funktion bezüglich des PVX-Replikase-Proteins aufdecken zu können, ist es notwendig in weiteren Studien 3D-Strukturen bzw. Kristalle mittels „X-ray“ Kristallographie des Moleküls zu bestimmen (z.B. Cao et al., 1997). Die Struktur von solchen Molekülen bzw. Proteinen könnte klassisch mit den experimentellen Methoden wie z.B. der Röntgenkristallographie oder der spektroskopischen NMR (,nuclear magnetic resonance“) gelöst werden. Die Herstellung von Kristallen ist jedoch ein langwieriger Prozess und es ist nicht geklärt, ob sich Kristalle für die PVX-Replikase züchten lassen. Hierfür müssten zunächst alle notwendigen Voraussetzungen beachtet und abgesichert werden.

Es würde sich jedoch mit Hilfe der dreidimensionalen Struktur die Frage der funktionellen Notwendigkeit aller drei Domänen innerhalb der PVX-Replikase/RdRp klären lassen, warum diese, verglichen zu anderen Replikasen, auf einem Molekül vorliegen bzw. verwirklicht sind. Im Allgemeinen wurde bereits gezeigt, dass die Kristallstruktur der RdRps eine gesamtheitliche Struktur verglichen $\mathrm{zu}$ anderen Polymerasen ausbildet (zusammengefasst in Ortín \& Parra, 2006; Ng et al., 2008). In Flint et al. (2003) sind diese strukturell miteinander verwandten Polymerasen bildlich dargestellt. Generell haben alle diese Polymerasen eine „rechte Hand“-Struktur, die eine Handflächen- (,palm“), Finger(,finger")- und Daumen- (,thumb“) Domäne aufweist (Ng et al., 2008). Die Vorhersage von Sekundärstrukturproteinen von fünf RdRps unterschiedlicher Virusfamilien zeigten ähnliche Eigenschaften, verglichen zu der Poliovirus 3D-Struktur, die bisher schon im Detail charakterisiert wurde (O'Reilly \& Kao, 1998). Für die Replikase der Potexviren liegt jedoch noch keine Erkenntnis über eine solche 3D-Struktur vor. Von Interesse wäre hierbei noch, jeweils die MT-, HEL- und POL Domänen der PVX-RdRp als einzelne 3D-Struktur darzustellen, in Anlehnung an frühere Studien, die diese Domänen für verschiedene RdRps bereits in Kristallform untersuchen konnten (z.B., MT: Zhou et al., 2007; HEL: Wu et al., 2005; POL: Ng et al., 2008).

Zusätzlich müssten noch Deletions-Mutagenesestudien durchgeführt werden, insbesondere von den PS-Mutanten, die innerhalb der Region liegen, die noch eine Toleranz gegenüber der 5 As-Insertion zeigten. Um diese Region, d.h. die Linkersequenz näher charakterisieren zu können, würden biochemische Studien von großem Nutzen sein. Hierfür könnten die Methoden aus Li et al. (1998) in Betracht gezogen werden. Als Beispiel seien hier die 
sogenannten Mutagenesestudien basierend auf PCR genannt (z.B. in Form von Deletionsstudien, wie sie bereits mit der Replikase des BaMV durchgeführt wurden oder auch evtl. mittels Alanin-Substitution), die innerhalb dieser PVX-Replikase-Linkersequenz durchgeführt werden müssten. Generell kann noch die Expression und Reinigung des ORF1 Replikase-Proteins des PVX in z.B. E. coli Zellen als Teil eines Fusionsproteins (z.B. mit Hexahistidin, Thioredoxin oder S•Tag), Aufschluss über die Aktivität bezogen auf die PVX-Replikasefunktion der jeweiligen MT-, HEL- und POL Domäne, einschließlich Linkerregion, liefern. Um die Replikase/RdRp-Aktivität dieser Fusionsproteine anschließend nachweisen zu können, müssten für die sogenannten in vitro Polymerase-assays verschiedene RNA-Transkripte, die innerhalb der in vitro Transkription erzeugt werden, eingesetzt werden (Li et al., 1998). Interessant wäre jedoch auch die Anwendung eines neuen Mutageneseverfahrens in Anlehnung an QuikChange ${ }^{\circledR}$ system Kit (Stratagene), basierend auf PCR-Mutagenese. Generell werden hierbei endogene Gensequenzen mit einer Markersequenz mit eindeutiger, ähnlicher Größe, ausgetauscht. Letztlich ist ohne eine dreidimensionale Struktur der PVX-Replikase die Methode der „pentapeptide scanning“ Mutagenese in ihrer Aussagekraft eingeschränkt, da sie nicht differenzieren kann, ob ein aktiver Bereich des Replikaseproteins durch eine Insertion getroffen oder ob die 3D-Struktur negativ beeinträchtigt wurde.

Der zweite Teil der vorliegenden Arbeit befasste sich mit der RNA-Rekombination bezogen auf Potato virus $X$ (PVX). Während dieser Arbeit wurde erstmals ein in vivo System für die detaillierte Charakterisierung der Parameter und Mechanismen der RNA-Rekombination des PVX unter Ausübung von starkem Selektionsdruck entwickelt. Das in vivo System basierte auf A. tumefaciens vermittelter transienter Expression von zwei parentalen viralen Transkripten, die für die RNA-Rekombination eingesetzt wurden. Für das finale Experiment der RNA-Rekombination wurde zunächst ein Defekt (Deletion) in das Hüllproteingen (CP) des GFP-exprimierenden, agroinfizierbaren und infektiösen cDNA Klons des PVX (Isolat UK3) unter Kontrolle des 35S-Pflanzenpromotors eingebaut, um dadurch die Ausbreitungsfunktion des PVX zu zerstören. Die resultierende CP-Deletionsmutante des PVX konnte anschließend über Agroinfektion mittels Infiltration von Nicotiana benthamiana Blattgewebe den infiltrierten Blattbereich der transient transformierten Zellen nicht verlassen. Ein in vivo intaktes CP-Transkript des PVX wurde anschließend für die virale RNA-Rekombination und Rekonstitution der Ausbreitungsfunktion als Template über Agroexpression angeboten. Die virale 
Ausbreitungsfunktion konnte schließlich nur rekonstituiert werden, wenn beide Konstrukte in $N$. benthamiana Blattgewebe co-exprimiert wurden, wobei dann letztlich die gesamte Pflanze systemisch mit PVX-GFP infiziert wurde. Einen Nachweis darüber, dass A. tumefaciens nicht für die beobachteten Rekombinationen verantwortlich ist, konnte über ein Partikelbombardment der beiden Plasmide auf abgetrennte $N$. benthamiana Blätter erbracht werden. Weiterhin wurde für die Agroinfektion anstelle des 35S-CP-UK3 ein promotorloses und doppelt-terminiertes CP-Gen verwendet. Hierbei führte das Einfügen von Terminationssignalen dazu, dass die Bildung von Transkripten in beiden Orientierungen durch pflanzliche Promotoren nach der Insertion verhindert und infolgedessen das Vorkommen von intakten PVX-Rekombinanten in diesem Experiment unterbunden wurde, was letztlich als indirekter Nachweis dafür galt, dass am wahrscheinlichsten RNA-Rekombination und nicht DNA-Rekombination für den beobachteten Effekt verantwortlich gemacht werden kann. Generell waren beide Systeme, d.h., die Agroinfiltration und das Partikelbombardment in der Lage, unabhängig voneinander mit zunehmender Häufigkeit den Ausbreitungsdefekt des PVX zu einem funktionellen PVX CP-Gen $\mathrm{zu}$ rekonstituieren. Vergleicht man diese Rekombinationshäufigkeit mit der aus früheren Studien, wobei der gleiche Selektionsdruck angewandt wurde, waren im Gegensatz zu zwei defekten cDNA Virusklonen oder der Expression eines intakten Gens, keine beachtlichen Unterschiede in transgenen Pflanzen nachzuweisen (Nagy \& Bujarski, 1993; Fernández-Cuartero et al., 1994; Goldbach \& Haan, 1994; Greene \& Allison, 1996; Jakab et al., 1997; Gal on et al., 1998; Borja et al., 1999; Adair \& Kearny, 2000; Varrelmann et al., 2000).

Der in dieser Arbeit verwendete GFP-markierte PVX „full-length“ cDNA-Klon erlaubte zum ersten Mal, verglichen mit früheren Untersuchungssystemen in vivo, eine genauere bzw. exaktere Aussage bezüglich des Vorkommens und der Häufigkeit der RNA-Rekombination. Im Detail kann mit dem hier neu etablierten System die Differenzierung von unabhängigen Rekombinanten, in ihrer Fähigkeit sich in der Wirtspflanze auszubreiten, detailliert analysiert bzw. charakterisiert werden. Weiterführende Arbeiten könnten sich mit der Erzeugung von Chimären beschäftigen, um deren Überlebensfähigkeit und „Fitness“ zu prüfen. Es würde somit in zukünftigen Studien die Möglichkeit bestehen, mit einem solchen System Evolution bzw. Evolutionsforschung zu betreiben (Schuster, 1999).

Anschließend stellte sich uns die Frage, ob es möglich sei, den genauen Zeitpunkt und die Häufigkeit der Rekombination innerhalb eines Agroinfektionsexperiments bestimmen zu 
können. Hierfür wurde der GFP-markierte PVX „full-length“ cDNA-Klon in einen 3'- und 5'-terminalen Bereich mit TGB1-Überlappung separiert. Mit Hilfe der GFP-Fluoreszenz Visualisierung innerhalb des infiltrierten Blattgewebes konnte anschließend die exakte Bestimmung der Rekombinationshäufigkeit und des -zeitpunkts vorgenommen werden. Diese Erkenntnis lässt sich für weitere Experimente anwenden, um evtl. den Einfluss von Umweltbedingungen hinsichtlich der Rekombinationsfrequenz nach Duggal \& Wimmer (1999) näher charakterisieren zu können. Interessant war jedoch, dass während dieser Studie eine sehr hohe Rekombinationsfrequenz, verglichen $\mathrm{zu}$ dem CP-DeletionsRekombinationsexperiment, nachzuweisen war, was wiederum nur durch die nicht vorhandene Fähigkeit beider Mutanten, sich autonom zu replizieren, erklärt werden kann. Um weitere Parameter (z.B. Rekombinationsfrequenz und Anzahl der Replikase/RdRpTemplatewechsel) der Rekombination detailliert bestimmen zu können, wurden vier weitere intakte CP-Transkripte unterschiedlicher PVX Typ-X Isolate für die Rekonstitution der CP-Defektmutante angeboten. Das Anbieten von solchen intakten CP-Transkripten mit einem Austausch von 20-31 nt innerhalb der Sequenz aufgrund der unterschiedlichen Isolate und einem Unterschied von 3 Aminosäuren, ermöglichte den Nachweis von Rekombinationsbereichen des postulierten Replikase/RdRp „template switch“ (Templatewechsel). In Abhängigkeit von der angebotenen intakten CP-Sequenz als Template für die Rekombination, wurden rekombinante PVX CP-Gene mit variabler Sequenz (As-Zusammensetzung; Markermutation) bestimmt. Es konnte jedoch nicht bei den einzelnen CP-Genen die Selektion auf chimäre Hüllproteingene mit bestimmter rekombinanter Sequenz beobachtet werden. Verglichen zu früheren Studien (Allison et al., 1996; Gal on et al., 1998; Borja et al., 1999; Varrelmann et al., 2000), konnte mit dem hier verwendeten Rekombinationssystem eine Vielzahl an Replikase/RdRp-Templatewechseln identifiziert werden, obwohl nur ein einziger ,template switch“ notwendig gewesen wäre, um die Rekonstitution des funktionellen Gens zu gewährleisten.

Des Weiteren stellte sich uns die Frage, ob die RNA-Rekombinationsfrequenz von der Länge und Homologie der Sequenzüberlappung abhängt. Hierbei konnte beobachtet werden, dass die Rekombinationsfrequenz des PVX in Abhängigkeit von der Länge (Sequenzüberlappung) der PVX-GFP CP-Deletionen invers proportional war. Diese Beobachtung stimmte mit früheren Erkenntnissen von Nagy \& Bujarski (1995) überein. Generell liefert dieses System zur Bestimmung der minimalen Überlappung der Sequenz einen neuen Ansatz für die biologische Sicherheitsforschung an transgenen virusresistenten Pflanzen. 
Weiterhin sind so genannte Heteroduplex-Strukturen (Hybridisierung von parentalen Strängen unterschiedlicher Herkunft), die homologe Regionen zusammenfügen, abhängig von der Länge der homologen Sequenz bzw. bilden sich einfach häufiger aus, wenn die überlappende homologe Region länger ist (Romanova et al., 1986; Tolskaya et al., 1987; Figlerowicz, 2000). Für zukünftige Arbeiten könnten solche Heteroduplex-Strukturen im Detail untersucht bzw. nachgewiesen werden. Zum einen könnte mit Hilfe der Elektronenmikroskopie die Heteroduplex-Struktur analysiert werden. Zum anderen kann der Nachweis noch auf unterschiedliche Art und Weise erfolgen, z.B. anhand von reinen Screening-Methoden oder aber besser noch durch reine Nachweisverfahren anhand der Primer-Extension-Mutagenese bzw. der PCR-Mutagenese. Im einfachsten Fall kann mit letzt genannter Methode aus Mutagenese- und Selektionsoligo, ein einziges Fragment erzeugt werden, dass letztlich wie bei der klassischen Mutagenese für die Hetereoduplexherstellung verwendet werden kann. Hierbei dient das erzeugte PCRFragment letztlich als megagroßer Primer für die DNA-Polymerase und besitzt gleichzeitig integrierte Mutations- und Selektionsabschnitte (z.B. Stratagen-Kit). Die reinen ScreeningMethoden basieren im Allgemeinen entweder auf dem Prinzip des unterschiedlichen Wanderverhaltens von Wildtyp- oder Mutanten-Heteroduplex-Strukturen in Elektrophorese-Gelen, oder auf der enzymatischen Restriktion von Heteroduplex-Strukturen. Generell findet eine langsamere elektrophoretische Wanderung bei HeteroduplexFormationen gegenüber den korrespondierenden Homoduplex-Strukturen statt.

Romanova et al. (1986) haben die Heteroduplex-Strukturen für das Poliovirusgenom im Detail untersucht und bereits Parallelen $\mathrm{zu}$ den Sekundärstrukturen gezogen. Die Heteroduplex-Strukturen können mit den „stem-loop“ Strukturen verglichen werden, da sie so genannte Haarnadelschleifen („hairpin“) ausbilden (Tolskaya et al., 1987).

Die Sequenz eines phylogenetisch entfernt verwandten PVX-4 Isolats (Typ-Bi) verglichen mit PVX-UK3 hinsichtlich des Hüllproteingens (CP) war, trotz der an sich sehr ähnlichen Länge, divergent, was zu einer reduzierten Rekombinationshäufigkeit nach Agroinfektion in $N$. benthamiana Blattgewebe führte. Dieses Ergebnis lässt schlussfolgern, dass die Homologie essentiell für eine präzise Rekonstitution des funktionellen CP-Gens ist. Diese Aussage wird ebenfalls bestärkt von der Beobachtung, dass keine Rekombination nachzuweisen war, wenn der Sequenzüberlappungsbereich von 50 auf 20 bp reduziert wurde bzw. kleiner als 50 bp war. Auf der anderen Seite erlaubt eine CP-PVX4-UK3 Rekombinante, aus einem solch entfernt verwandten PVX4 kombiniert mit dem PVX-UK3-Isolat, eine deutlich präzisere Feststellung der Rekombinationsorte. Der 
Abstand zwischen den auftretenden Markermutationen innerhalb der CP-PVX4-UK3 Rekombinanten variierte zwischen 2-21 bp, was als Beweis dafür galt, dass „mismatches“ in der essentiellen homologen Sequenz teilweise toleriert wurden, um letztlich eine effiziente Rekombination zu stützen. In Anlehnung an diese Erkenntnis konnte eine frühere Studie von Nagy \& Bujarski (1995) zeigen, dass eine Nukleotid-Übereinstimmung von nur 15 bp zwischen parentalen BMV Sequenzen bereits zu einer effizienten homologen Rekombination führte. Um solche Homologie-abhängigen Grenzbereiche der präzisen Rekombination exakt bestimmen zu können, müssten in weiteren Experimenten Deletionsmutanten, mit einer genaueren Bestimmtheit und häufigeren Anzahl von Wiederholungen, erzeugt werden. Die Ergebnisse veranlassten uns dazu, weitere Schlüsse zuzulassen, dass die homologe PVX-Rekombination nicht häufiger in Anlehnung an den „breakage and ligation“ Rekombinationsmechanismus (siehe Einleitung) vorkommt, als früher angenommen. Für Untersuchungen von nicht-replikativer „,breakage and ligation“ Rekombination durch Wirtszellen codierende RNA-Ligasen müssten zwei PVX-DeletionsKonstrukte verwendet werden, um das Replikase/RdRp-Gen in zwei nicht-überlappende Fragmente zu trennen.

Weiterhin konnte die in dieser Arbeit nachgewiesene Rekombination nach Nagy \& Simon (1997) als „Similarity-Assisted“ Klasse 3 Rekombination klassifiziert werden. Die Computersoftware „Mfold“ (Zuker, 2003) ließ eine Prognose der RNA-Sekundärstruktur an den jeweiligen Rekombinationsorten (,,junction sites“) zu. In früheren Studien konnte bereits gezeigt werden, dass intermolekulare Sekundärstrukturen (z.B. „stem-loop“) Bestandteil der nicht-homologen oder ,Similarity Non-essential“ Rekombinationsorte sind. Als Beispiele hierfür seien folgende Viren genannt, Brome mosaic virus (BMV), Turnip crinkle virus (TCV), Tomato bushy stunt virus (TBSV) und Genus Cucumovirus (Cascone et al., 1993; White \& Morris, 1994; Carpenter et al., 1995; Nagy \& Simon, 1998; Nagy et al., 1998; Figlerowicz, 2000; Cheng \& Nagy, 2003; Suzuki et al., 2003; de Wispelaere et al., 2005). Hingegen konnten Nagy \& Bujarski (1995) keine eindeutige Korrelation zwischen der RNA-Sekundärstruktur und den homologen Rekombinationsorten nachweisen. In unserem Experiment zeigten Sequenzanalysen von 15 unabhängigen CP-UK3-PVX4 Rekombinanten, dass sich jede Rekombinante als ein Unikat auf RNAEbene erwies und die ,junction sites“ bzw. Rekombinationsorte (Templatewechsel) hierbei am häufigsten an 5 Orten um die CP-Deletion verteilt, auftraten. Die Prognose der RNASekundästruktur (Mfold) zeigte, dass diese ,junction sites“ sowie alle weiteren identifizierten Rekombinationsorte jeweils mit den vorhergesagten „stem-loop“-Strukturen 
co-lokalisiert waren. Dies führte zu der Erkenntnis, dass bei einer präzisen PVXRekombination RNA-Sekundärstrukturen involviert waren. Diese strukturierten doppelsträngigen Regionen könnten zu einer Dissoziation der Replikase/RdRp führen oder zu einer Template-Dissoziation (Nagy \& Simon, 1997; Jager \& Pata, 1999) und möglicherweise zu einem ,template switch“ (Templatewechsel) in einem nicht strukturierten „loop“. Eine solche Erkenntnis steht jedoch im Kontrast zu den homologen Rekombinationsergebinssen, die bei BMV (Olsthoorn et al., 2002) beobachtet wurden, wobei eine Reduktion der homologen Akkumulation festgestellt wurde und dies schließlich keinen Beweis für eine Verzögerung der Replikase/RdRp-Pausierung bzw. einen Abbruch der RNA-Synthese lieferte, wenn „stem-loop“-Strukturen in parentalen Sequenzen vorhanden waren. Auf der anderen Seite konnte jedoch für BMV demonstriert werden, dass intercistronisch subgenomische Promotorsequenzen ( $\mathrm{sgPr}$ ), bestehend aus AU-reichen Regionen und einer Replikase/RdRp-bindenden „stem-loop“- Struktur, die homologe Rekombinationsaktivität erhöhen (Nagy et al., 1999; Bruyere et al., 2000; Wierzchoslawski et al., 2004). Dennoch, auch wenn das PVX CP-ORF den meisten 3'ORF im Genom repräsentiert, gibt es bis dato keinen Beweis dafür, dass ein solch interner sgPr im CP-ORF vorliegt. In Anlehnung daran, dass unser experimentelles System nur die Vervielfältigung der ausbreitungsintakten CP-Gene selektiert und damit nur präzise Rekombinationsereignisse (keine ,mismatch“ Mutationen in der Nähe von ,junction sites") nachgewiesen werden konnten, erlaubten die demonstrierten Ergebnisse eine Klassifizierung der präzisen Rekombination nach Nagy \& Simon (1997) in Klasse 3: „Similarity-Assisted“ Rekombination. Ein weiteres Beispiel für eine Klasse 3 Rekombination wurde bereits in früheren Studien zu Turnip crinkle virus (TCV) Satelliten-RNA geliefert (Cascone et al., 1993; Nagy et al., 1998). Dennoch konnten Rekombinations-,,hot spots“ beobachtet werden, die sich an der Basis eines „hairpin“ Motivs angehäuft haben.

Final konnte demonstriert werden, dass zwei ,pentapeptide scanning“ PS-Mutanten aus dem ersten Teil der vorliegenden Arbeit sich zwar noch replizierten, jedoch in ihrer Fähigkeit zu rekombinieren, stark eingeschränkt waren. Dieses Ergebnis stärkte die Aussage des replikativen ,template switch“ Mechanismus (zusammengefasst in Gmyl \& Agol, 2005), wie anfangs in der Einleitung beschrieben und die Beobachtungen aus früheren Studien von Nagy \& Bujarski (1995) und Figlerowicz et al. (1997 und 1998), die bereits im Pflanzenvirus Replikase/RdRp-Mutanten identifiziert haben, die ebenfalls Rekombinationsparameter beeinflussten. Bezogen auf diese Arbeit lieferte das Ergebnis 
die Bestätigung dafür, dass die virale PVX-Replikase für die Rekombination verantwortlich war und es sich somit um eine RNA- und nicht DNA-Rekombination in diesen Experimenten handelte. Es konnte somit erstmalig eine Domäne innerhalb des PVX-Replikaseproteins bestimmt werden, die für die Rekombination verantwortlich gemacht werden kann.

Zusammenfassend kann dieses experimentelle System für eine einfache und unkomplizierte Charakterisierung von Rekombinationsparametern in anderen viralen Systemen angewendet werden, für die bereits „full length“ Klone zur Verfügung stehen. Eine mögliche Anwendung könnte das hier etablierte System für den Einsatz von Pflanzenexpressionsvektoren liefern, die dann ihre Inserts nicht mehr über RNARekombination aus dem Genom entfernen können. Die Identifizierung der Rekombinanten zwischen phylogenetisch distanzierten Typ-X und Typ-Bi CP-Gen Isolaten demonstrierte den Hergang der RNA-Rekombination unter hohem Selektionsdruck, um weitere virale RNA-Genome mit unterschiedlichen biologischen Eigenschaften $\mathrm{zu}$ entwickeln. Nachweise und Überprüfungen von RNA Sequenz- und Strukturelementen, die den Ort der RNA-Rekombination beeinflussen, könnten identifiziert und analysiert werden. Beispiele hierfür sind „cis-acting“ Elemente (zusammengefasst in Hu et al., 2007), „crossover sites“, eingenommen Heteroduplex-Strukturen (Romanova et al. 1986) sowie Basenpaarung und Signale, die für den Abbruch bzw. die Reinitiation der RNA-Synthese verantwortlich sind und damit die Rekombinationshäufigkeit und -genauigkeit beeinflussen können. Weiterhin kann die Herstellung von in vitro transkribierten RNAs noch weitere Schlüsse über den Mechanismus der RNA-Rekombination zulassen. Es könnte folglich ein zusätzliches RNA-Rekombinationsassay etabliert werden, um die eben genannten Parameter charakterisieren zu können. 


\section{LITERATUR}

Adair, T.L. \& Kearney, C.M. (2000). Recombination between a 3-kilobase tobacco mosaic virus transgene and a homologous viral construct in the restoration of viral and nonviral genes. Arch. Virol. 145: 1867-1883.

Allison, R. F., Schneider, W.L. \& Greene, A.E. (1996). Recombination in plants expressing viral transgenes. Semin. Virol. 7: 417-422.

Borja, M., Rubio, T., Scholthof, H.B. \& Jackson, A.O. (1999). Restoration of wild-type virus by double recombination of tombusvirus mutants with a host transgene. MPMI 12: 153-162.

Bruyere, A., Wantroba, M., Flasinski, S., Dzianott, A. \& Bujarski, J.J. (2000). Frequent homologous recombination events between molecules of one RNA component in a multipartite RNA virus. J. Virol. 74: 4214-4219.

Cao, Y., Hallet, B., Sherratt, D.J. \& Hayes, F. (1997). Structure-function correlations in the XerD site-specific recombinase revealed by pentapeptide scanning mutagenesis. J. Mol. Biol. 274: 39-53.

Carpenter, C.D., Oh, J.W., Zhang, C. \& Simon, A.E. (1995). Involvement of a stemloop structure in the location of junction sites in viral RNA recombination. J. Mol. Biol. 245: 608-622.

Cascone, P.J., Haydar, T.F. \& Simon, A.E. (1993). Sequences and structures required for recombination between virus-associated RNAs. Science 260: 801-805.

Chapman, S., Kavanagh, T. \& Baulcombe, D.C. (1992). Potato virus X as a vector for gene expression in plants. The Plant Journal 2(4): 549-557.

Cheng, C. P. \& Nagy, P.D. (2003). Mechanism of RNA recombination in carmo- and tombusviruses: evidence for template switching by the RNA-dependent RNA polymerase in vitro. J. Virol. 77(22): 12033-12047. 
Cunningham, B.C. \& Wells, J.A. (1989). High-resolution epitope mapping of hGHreceptor interactions by alanine-scanning mutagenesis. Science 244: 1081-1085.

De Wispelaere, M., Gaubert, S., Trouilloud, S., Belin, C. \& Tepfer, M. (2005). A map of the diversity of RNA3 recombinants appearing in plants infected with Cucumber mosaic virus and Tomato aspermy virus. Virology 331: 117-127.

Duggal, R. \& Wimmer, E. (1999). Genetic recombination of poliovirus in vitro and in vivo: temperature-dependent alteration of crossover sites. Virology 258: 30-41.

Dykxhoorn, D.M., Pierre, R.St., Van Ham, O. \& Linn, T. (1997). An efficient protocol for linker scanning mutagenesis: analysis of the translational regulation of an Escherichia coli RNA polymerase subunit gene. Nucleic Acids Res. 25: 4209-4218.

Fernández-Cuartero, B., Burgyán, J., Aranda, M.A., Salánki, K., Moriones, E. \& García-Arenal, F. (1994). Increase in the relative fitness of a plant virus RNA associated with its recombinant nature. Virology 203: 373-377.

Figlerowicz, M. (2000). Role of RNA structure in non-homologous recombination between genomic molecules of brome mosaic virus. Nucleic Acids Res. 28: 1714-1723.

Figlerowicz, M., Nagy, P.D. \& Bujarski, J.J. (1997). A mutation in the putative RNA polymerase gene inhibits nonhomologous, but not homologous, genetic recombination in an RNA virus. Proceedings of the National Academy of Sciences, USA 94: 2073-2078.

Figlerowicz, M., Nagy, P.D., Tang, N., Kao, C.C. \& Bujarski, J.J. (1998). Mutations in the $\mathrm{N}$ terminus of the brome mosaic virus polymerase affect genetic RNA-RNA recombination. J. Virol. 72: 9192-9200.

Flint, S.J., Enquist, L.W., Racaniello, V.R. \& Skalka, A.M. (2003). Principles of Virology: Molecular Biology, Pathogenesis, and Control of Animal Viruses, 2nd Edition. American Society for Microbiology Press. 
Fransen, M., Vastiau, I., Brees, C., Brys, V., Mannaerts, G.P. \& Van Veldhoven, P.P. (2005). Analysis of human Pex19p's domain structure by pentapeptide scanning mutagenesis. J. Mol. Biol. 346: 1275-1286.

Gal-On, A., Meiri, E., Raccah, B. \& Gaba, V. (1998). Recombination of engineered defective RNA species produces infective potyvirus in planta. J. Virol. 72: 5268-5270.

Ghazala, W., Waltermann, A., Pilot, R., Winter, S. \& Varrelmann, M. (2008). Functional characterization and subcellular localization of the $16 \mathrm{~K}$ cysteine-rich suppressor of gene silencing protein of Tobacco rattle virus. J. Virol. 89(Pt 7): 1748-1758.

Gmyl, A.P. \& Agol, V.I. (2005). Diverse mechanisms of RNA recombination. Molecular Biology 39(4): 529-542.

Goldbach, R. \& de Haan, P.. (1994). RNA viral supergroups and the evolution of RNA viruses. In The Evolutionary Biology of Viruses. 105-119. Edited by S. Morse. New York: Raven Press.

Greene, A.E. \& Allison, R.F. (1996). Deletions in the 3' untranslated region of cowpea chlorotic mottle virus transgene reduce recovery of recombinant viruses in transgenic plants. Virology 225: 231-234.

Hallet, B., Sherratt, D.J. \& Hayes, F., (1997). Pentapeptide scanning mutagenesis: random insertion of a variable five amino acid cassette in a target protein. Nucleic Acids Res. 25: 1866-1867.

Han, Y. T., Tsai, C.S., Chen, Y.C., Lin, M.K., Hsu, Y.H. \& Meng, M. (2007). Mutational analysis of a helicase motif-based RNA 5'-triphosphatase/NTPase from bamboo mosaic virus. Virology 367(1): 41-50.

Hu, B., Pillai-Nair, N. \& Hemenway, C. (2007). Long-distance RNA-RNA interactions between terminal elements and the same subset of internal elements on the potato virus $\mathrm{X}$ genome mediate minus- and plus-strand RNA synthesis. RNA 13: 267-280. 
Huang, Y.L., Han, Y.T., Chang, Y.T., Hsu, Y.H., Meng, M., (2004). Critical Residues for GTP Methylation and Formation of the Covalent $\mathrm{m}^{7}$ GMP-Enzyme Intermediate in the Capping Enzyme Domain of Bamboo Mosaic Virus. J. Virol. 78 (3): 1271-1280.

Jager, J., \& Pata J.D. (1999). Getting a grip: polymerases and their substrate complexes. Curr. Opin. Struct. Biol. 9: 21-28.

Jakab, G., Vaistij, F.E., Droz, E. \& Malnoë, P. (1997). Transgenic plants expressing viral sequences create a favourable environment for recombination between viral sequences. In Virus-Resistant Transgenic Plants: Potential Ecological Impact. 45-51. Edited by M. Tepfer \& E. Balázs. Versailles \& Heidelberg: INRA \& Springer-Verlag.

Kong, F., Sivakumaran, K. \& Kao, C. (1999). The N-Terminal Half of the Brome Mosaic Virus 1a Protein Has RNA Capping-Associated Activities: Specificity for GTP and S-Adenosylmethionine. Virology 1:200-210.

Koonin, E.V. (1991). The phylogeny of RNA-dependent RNA polymerases of positivestrand RNA viruses. J. Gen. Virol. 72: 2197-2206.

Koonin, E.V. \& Dolja, V.V. (1993). Evolution and taxonomy of positive-strand RNA viruses: implications of comparative analysis of amino acid sequences. Critical Reviews in Biochemistry and Molecular Biology 28(5): 375-430.

Li, Y.I., Cheng, Y.M., Huang, Y.L., Tsai, C.H., Hsu, Y.H. \& Meng, M. (1998). Identification and characterization of the Escherichia coli-expressed RNA-dependent RNA polymerase of bamboo mosaic virus. J. Virol. 72 (12): 10093-10099.

Li, Y.I., Chen, Y.J., Hsu, Y.H., Meng, M. (2001a). Characterization of the AdoMetdependent guanylyltransferase activity that is associated with the $\mathrm{N}$ terminus of bamboo mosaic virus replicase. J. Virol. 75(2): 782-788. 
Li, Y.I., Shih, T.W., Hsu, Y.H., Han, Y.T., Huang, Y.L. \& Meng, M. (2001b). The helicase-like domain of plant Potexvirus replicase participates in formation of RNA $5^{\prime}$ cap structure by exhibiting RNA 5'-triphosphatase activity. J. Virol. 75 (24): 12114-12120.

Liou, M.R., Chen, Y.R. \& Liou, R.F. (2004). Complete nucleotide sequence and genome organization of a Cactus virus $X$ strain from Hylocereus undatus (Cactaceae). Arch. Virol. 149: 1037-1043.

Longstaff, M., Brigneti, G., Boccard, F., Chapman, S. \& Baulcombe, D., (1993). Extreme resistance to potato virus $\mathrm{X}$ infection in plants expressing modified components of the putative viral replicase. EMBO J. 12: 379-386.

Nagy, P.D. \& Bujarski, J.J. (1993). Targeting the site of RNA-RNA recombination in brome mosaic virus with antisense sequences. Proc. Natl. Acad. Sci. USA 90: 6390-6394.

Nagy, P.D. \& Bujarski, J.J. (1995). Efficient system of homologous RNA recombination in brome mosaic virus: sequence and structure requirements and accuracy of crossovers. J. Virol. 69: 131-140.

Nagy, P.D. \& Simon, A.E. (1997). New insights into the mechanisms of RNA recombination. Virology 235: 1-9.

Nagy, P.D. \& Simon, A.E. (1998). In vitro characterization of late steps of RNA recombination in turnip crinkle virus. I. Role of the motifl-hairpin structure. Virology 249: 379-392.

Nagy, P.D., Zhang, C. \& Simon, A.E. (1998). Dissecting RNA recombination in vitro: role of RNA sequences and the viral replicase. EMBO J. 17: 2392-2403.

Nagy, P.D., Pogany, J. \& Simon, A.E. (1999). RNA elements required for RNA recombination function as replication enhancers in vitro and in vivo in a plus-strand RNA virus. EMBO J. 18(20): 5653-65. 
Ng, K.K.S., Arnold, J.J. \& Cameron, C.E. (2008). Structure-Function Relationships Among RNA-Dependent RNA Polymerases. Curr. Top Microbil. Immunol. 320: 137-156.

Olsthoorn, R.C.L., Bruyére, A., Dzianott, A. \& Bujarski, J.J. (2002). RNA recombination in brome mosaic virus: effects of strand-specific stemloop inserts. J. Virol. 76: 12654-12662.

O'Reilly, E.K. \& Kao, C.C. (1998). Analysis of RNA-dependent RNA polymerase Structure and function as guided by known polymerase structures and computer predictions of secondary structure. Virology. 252: 287-303.

Ortin, J. \& Parra, Francisco. (2006). Structural Function of RNA Replication. Annu. Rev. Microbiol. 60: 305-326.

Petyuk, V., McDermott, J., Cook, M. \& Sauer, B. (2004). Fuctional Mapping of Cre recombinase by Pentapeptide Insertional Mutagenesis. J. Biol. Chemistry 279: 3704037048 .

Poussu, E., Vihinen, M., Paulin, M. \& Savilahti, H. (2004). Probing the $\alpha$ Complementing Domain of $E$. coli $\beta$-Galactosidase with use of an insertional pentapeptide mutagenesis strategy based on $\mathrm{Mu}$ in vitro DNA transposition. Proteins: Structure, Function, and Bioinformatics 54: 681-692.

Poussu, E., Jäntti, J. \& Savilahti, H. (2005). A gene truncation strategy generating Nand C-terminal deletion variants of proteins for functional studies: mapping of the Sec1p binding domain in yeast Msolp by a $\mathrm{Mu}$ in vitro transposition-based approach. Nucleic Acids Res 33(12): e104.

Romanova, L.I., Blinov, V.M., Tolskaya, E.A., Viktorova, E.G., Kolesnikova, M.S., Gueseva, E.A. \& AGOL, V.I. (1986). The primary structure of crossover regions of intertypic poliovirus recombinants: A model of recombination between RNA genomes. Virology 155: 202-213. 
Rozanov, M.N., Koonin, E.V. \& Gorbalenya, A.E. (1992). Conservation of the putative methyltransferase domain: a hallmark of the 'Sindbis-like' supergroup of positive-strand RNA viruses. J. Gen. Virol. 73: 2129-2134.

Schuster, P. (1999). Mendel-Vorlesung: Evolution der Moleküle. Einblicke in die Natur mit Perspektiven für die Biotechnologie.

Suzuki, M., Hibi, T. \& Masuta, C. (2003). RNA recombination between cucumoviruses: possible role of predicted stem-loop structures and an internal subgenomic promoter-like motif. Virology 306: 77-86.

Tolskaya, E.A., Romanova, L.A., Blinow, V.M., Viktorova, E.G., Sinyakov, A.N., Kolesnikova, M.S. \& Agol, V.I. (1988). Studies on the recombination between RNA genomes of poliovirus: the primary structure and nonrandom distribution of crossover regions in the genomes of intertypic poliovirus recombinants. Virology 161: 54-61.

Van der Heijden, M.W. \& Bol, J.F. (2002). Composition of alphavirus-like replication complexes: involvement of virus and host encoded proteins. Arch. Virol. 147: 875-898.

Van der Vlugt, R.A.A. \& Berendsen, M. (2002). Development of a General Potexvirus Detection Method. European Journal of Plant Pathology 108: 367-371

Varrelmann, M., Palkovics, L. \& Maiss, E. (2000). Transgenic or plant expression vector-mediated recombination of plum pox virus. J. Virol. 74: 7462-7469.

Varrelmann, M., Maiss, E., Pilot, R. \& Palkovics, L. (2007). Use of pentapeptide insertion scanning mutagenesis for functional mapping of the plum pox virus helper component proteinase suppressor of gene silencing. Virology 74: 7462-7469.

White, K.A. \& Morris, T.J. (1994). Recombination between defective tombusvirus RNAs generates functional hybrid genomes. Proc. Natl. Acad. Sci. USA 91: 3642-3646. 
Wierzchoslawski, R., Dzianott, A. \& Bujarski, J. (2004). Dissecting the requirement for subgenomic promoter sequences by RNA recombination of brome mosaic virus in vivo: evidence for functional separation of transcription and recombination. J. Virol. 78: 85528564.

Wu, J., Kumar Bera, A., Kuhn, R.J. \& Smith, J.L. (2005). Structure of the Flavivirus Helicase: Implications for Catalytic Activity, Protein Interactions, and Proteolytic Processing. J. Virol. 79: 10268-10277.

Yeh, T.Y., Lin, B.Y., Chang, Y.C., Hsu, Y.H. \& Lin, N.S. (1999). A defective RNA dissociated with bamboo mosaic virus and the possible common mechanisms for RNA recombination in Potexviruses. Virus Genes 18(2): 121-128.

Zhou, Y., Ray, D., Zhao, Y., Dong, H., Ren, S., Li, Z., Guo, Y., Bernard, A. \& Shi, P.Y. (2007). Structure and Function of Flavivrus NS5 Methyltransferase. J. Virol. 81(8): 3891-3903.

Zuker, M. (2003). Mfold web server for nucleic acid folding and hybridization prediction. Nucleic Acids Res. 31: 3406-3415. 


\section{Zusammenfassung}

Innerhalb der RNA-Viren besitzt die Rekombination eine wichtige Rolle bei der viralen Adaption, Genomreparatur und bei der Erzeugung von Diversität. Für eine Replikation und Rekombination von pflanzenviraler RNA ist eine Interaktion zwischen viraler RNA und der Replikase bzw. RNA-abhängigen RNA-Polymerase (RdRp) essentiell. Für das Potato virus X (PVX), Genus Potexvirus, Mitglied der Familie Felxiviridae und der ,alpha-like“ Virusgruppe, konnte bisher nur über das Auftreten von Deletionen in Expressionsvektoren ein indirekter Rekombinationsnachweis geführt werden. Innerhalb der Potexviren konnte das Auftreten von „defective“ RNAs (D RNAs) bei Bamboo mosaic virus (BaMV) als eine indirekte RNA-Rekombination beobachtet werden und bei Cymbidium mosaic virus (CymMV) anhand von phylogenetischer Untersuchungen, Die Art der Rekombination und die funktionelle Charakterisierung der an der Rekombination beteiligten Replikase/RdRp des PVX sind bis dato nicht untersucht.

In der hier vorliegenden Arbeit wurde zum ersten Mal ein in vivo Agrobakterium vermitteltes Rekombinationssystem, ausgestattet mit einem GFP-Fluoreszenz Markergen, entwickelt, um die RNA-Rekombination und den RNA-Rekombinationsmechanismus unter hohem Selektionsdruck sowie die Funktion der Replikation des PVX, detailliert zu charakterisieren.

$\mathrm{Zu}$ diesem Zweck wurde zunächst in das Hüllproteingen (CP) des agroinfizierbaren „fulllength“ PVX-Klons (35S-PVX-GFP) eine Deletion eingefügt und somit die Virusausbreitung zerstört. Um die virale RNA Rekombination und Rekonstitution der Ausbreitungsfunktion wieder $\mathrm{zu}$ ermöglichen, wurde ein intaktes $35 \mathrm{~S}$ in vivo $\mathrm{CP}$ Transkript (35S-CP $\mathrm{PVX}_{\mathrm{PV}-3}$ '-ntr) inklusive viralem 3'-NTR-Transkript über Agrobacterium tumefaciens in Nicotiana benthamiana co-exprimiert. Nur wenn beide Konstrukte in einem $N$. benthamiana Blattgewebe Bereich co-infiltriert wurden, konnte die Virusausbreitung erfolgen und die Pflanzen waren systemisch mit PVX-GFP infiziert. Eine Sequenzuntersuchung von unabhängigen PVX-UK3 Rekombinanten zeigte, dass in allen Fällen die exakte Wildtypsequenz PVX-UK3 mit intaktem CP-Gen rekonstituiert wurde.

Um eine Rekombination aufgrund von A. tumefaciens vermittelter DNA Rekombination eingrenzen bzw. ausschließen zu können, wurden mehrere unabhängige Untersuchungen durchgeführt. Als erster Beweis, dass es sich hierbei tatsächlich um RNA Rekombination handelte, galt das Ergebnis des Partikelbombardments auf abgetrennte $N$. benthamiana 
Blätter obiger in vivo Transkripte sowie eines zusätzlichen promotorlosen und doppelt(,sense“ und ,antisense“) terminierten CP-Gen-Konstrukts (35S-CP-no-transcripts), co-agroinfiltriert mit der CP-defekten Mutante.

Aus der von mir erzeugten PVX-Replikase Bibliothek wurden zwei replikationsaktive PVX-Replikase PS-Mutanten (35S-PVX-GFP-PS430 und -PS434) als weiterer Beweis für die RNA Rekombination näher untersucht. Nach Co-Agroinfektion beider Mutanten mit $35 \mathrm{~S}-\mathrm{CP}_{\mathrm{PVX}}-3$ '-ntr in $N$. benthamiana Blattgewebe konnte die Fähigkeit nachgewiesen werden, das Wildtyp-Genom zu amplifizieren. Jedoch waren diese Mutanten, in ihrer Fähigkeit zu rekombinieren, stark eingeschränkt.

In einem weiteren Teil der Arbeit wurde erneut auf das transiente Agro-Expressionssystem zurückgegriffen und eine funktionelle Charakterisierung der Replikationsfunktion der PVX-Replikase durchgeführt. Zunächst konnte unter Verwendung von transposonvermittelter „pentapeptide scanning“ Mutagenese (PSM) eine gesättigte Insertionsbibliothek der an der Replikation beteiligten Replikase/RdRp des PVX hergestellt (zunächst in einem Subklon) und diese anschließend in den infektiösen PVXKlon mit CP-Deletion eingefügt werden. Jede einzelne PS-Mutante wurde mittels in vivo Expressionssystem untersucht. Nach 3 und 5 dpi wurden die GFP-Expressionsergebnisse nach Agroinfiltration in $N$. benthamiana Blätter mittels Fluoreszenzmikroskopie (FM) dargestellt. Es erfolgte im Anschluss eine Klassifizierung der Mutanten in drei Klassen (I-III), wobei hier die Intensität der GFP-Fluoreszenz, verglichen mit der Wildtypsequenz des PVX, in Betracht gezogen wurde.

Durch das Vorhandensein einer mutationsspezifischen Restriktionsschnittstelle konnten die PS-Mutanten mittels RFLP auf die ungefähre Position der „pentapeptide“ Insertion kartiert werden. Anschließend erfolgte dann die Sequenzierung der Insertionen sämtlicher Mutanten hinsichtlich der replikationsaktiven Bereiche des Proteins. Die Ergebnisse zeigten dabei eine gleichmäßige Verteilung der Mutationen über den gesamten ReplikaseORF des PVX und wurden im Hintergrund der aus der Literatur bekannten funktionellen Bereiche von viralen Polymerasen (Methyltransferase, Helikase und Polymerase) der „alpha-like“ Virusgruppe diskutiert. Der Großteil der PS-Mutanten zeigte eine Intoleranz gegenüber der 5 aa Insertion und daraus resultierend einen Verlust der Replikationsfähigkeit. 10 Mutanten konnten sich, trotz der Insertion, weiterhin mehr oder weniger stark verglichen zur Wildtypsequenz des PVX, replizieren. Weiterhin konnte anhand von Western-blot Untersuchungen demonstriert werden, dass die 5 aa Insertion von 
ausgewählten aktiven und inaktiven PS-Mutanten keinen Einfluss hat auf das Expressionsverhalten bzw. die Stabilität des RdRp/Replikase Proteins.

Abschließend wurden Sequenzanalysen auf Aminosäureebene der Replikase/RdRp von 16 verschiedenen Potexviren durchgeführt. Dabei zeigte sich, dass die Sequenzidentität der PVX-Replikase verglichen zu anderen Potexviren sehr gering war. Generell lag die Homologie aller Potexviren Sequenzen zwischen $34,4 \%$ bis $65,4 \%$.

Zusammengefasst liefert das Rekombinationssystem, mittels transienter Agroexpression eine schnelle und einfache Methode, um virale Rekombination und Replikation in Pflanzen $\mathrm{zu}$ charakterisieren. Es ist außerdem eine Alternative für den Einsatz von transgenen Pflanzen, die virale Sequenzen exprimieren. 


\section{Danksagung}

An dieser Stelle danke ich zunächst Herrn Prof. Dr. Mark Varrelmann, dass er die Betreuung dieser Dissertation befürwortete sowie für die Überlassung des Themas und die ständige Diskussionsbereitschaft. Herrn Prof. Dr. Edgar Maiß möchte ich meinen Dank für die Übernahme des Korreferats der vorliegenden Arbeit aussprechen.

Des Weiteren bedanke ich mich bei der pflanzenvirologischen Arbeitsgruppe des Departments für Nutzpflanzenwissenschaften für die fortwährende Hilfsbereitschaft. Dieser Dank richtet sich insbesondere an die technische Assistentin, Ruth Pilot, für die Unterstützung vor allem während der Endphase meiner Arbeit. Ein Dankeschön gilt auch den anderen Arbeitsgruppen des Instituts und vor allem den jeweiligen Auszubildenden, die während der Zeit in unserem Labor angelernt wurden und unter anderem jederzeit für meine Arbeit „eingespannt““ werden konnten. Michael Zarnow möchte ich ein besonders großes „Dankeschön“ aussprechen für seine auf Abruf spontane Hilfsbereitschaft, um mich bei meiner praktischen Laborarbeit als Assistent zu unterstützen.

Für die Hilfsbereitschaft bei Formatproblemen und Korrekturarbeiten bedanke ich mich besonders bei Julia Busse. Danke, dass Du, egal wann es ein Problem gab, sofort zur Stelle warst. Ebenso danke ich allen meinen Freunden, die mich immer wieder, besonders in der Endphase meiner Arbeit, aufgemuntert und kein Mittel ausgelassen haben, um mich abzulenken und insbesondere vom Schreibtisch an die „frische Luft“ zu locken.

Bei der deutschen Forschungsgemeinschaft (DFG) bedanke ich mich für die Finanzierung dieser Arbeit.

Letztendlich geht der größte Dank an meine Eltern Marion und Rudolf Draghici, da sie mir das Studium ermöglicht haben und jede meiner Entscheidungen immer vollends akzeptiert und in jeglicher Konsequenz mitgetragen haben. Ich danke Euch von ganzem Herzen. 


\section{Lebenslauf}

Name:

Heidrun-Katharina Draghici

Geburtsdatum:

27. Mai 1976

Geburtsort:

Hermannstadt (Sibiu), Rumänien

Staatsangehörigkeit:

deutsch

\section{Berufserfahrungen}

$01 / 2007-09 / 2007$

Kooperationsforschung für „Syngenta seeds“

Seit $11 / 2003$

$08 / 2003-10 / 2003$

$04 / 2002-03 / 2003$

\section{Hochschulstudium}

WS 1996- SS 2003

Studium der Biologie an der Georg-August Universität Göttingen

\section{Schulausbildung}

$09 / 95-11 / 95$

$1992-1995$

$1988-1992$

$1986-1988$

$1982-1986$
Wissenschaftliche Mitarbeiterin

Department für Nutzpflanzenwissenschaften (DNPW) Abteilung Pflanzenvirologie, Universität Göttingen

- Promotion:

„Funktionelle Charakterisierung der Replikations- und Rekombinationsfunktionen der RNA-abhängigen RNAPolymerase (RdRp) des Potato virus X (PVX)“

Wissenschaftliche Mitarbeiterin (KWS SAAT AG, Einbeck)

Diplomandin (Planta GmbH, Einbeck)

\section{- Diplom:}

Analyse des Expressionsverhaltens der Genfamilie der „Subtilisin-ähnlichen Proteasen“ der Zuckerrübe und funktionale Charakterisierung des BvSap3-Promotors Abschluss: Dipl. Biologin

Au-pair mit Schulbesuch in England (Bournemouth)

Besuch des Fachgymnasiums für Ernährung und Hauswirtschaft, Einbeck; Abschluss: Abitur Besuch der Löns-Realschule, Einbeck Besuch der Orientierungsstufe, Einbeck Besuch der Pestalozzi-Grundschule, Einbeck 